\title{
COMPARAÇÃO DE PROGÊNIES DE
}

\section{POPULAÇÕES NATURAIS E RAÇAS LOCAIS \\ DE Eucalyptus urophylla S.T. Blake}

\section{HORÁCIO DE FIGUEREDO LUZ}

Engenheiro Florestal e Agrônomo

ORIENTADOR: Prof. Dr. ANTONIO NATAL GONÇALVES

Dissertação apresentada à Escola Superior de Agricultura "Luiz de Queiroz", Universidade de São Paulo, para obtenção do título de Mestre em Ciências - Área de Concentração: Ciências Florestais

PIRACICABA

Estado de São Paulo - Brasil

Janeiro - 1997 
Dados Internacionais de Catalogação na Publicação (CIP) DIVISĀO DE BIBLIOTECA E DOCUMENTAÇĀO - Campus "Luiz de Queiroz"/USP

Luz, Horácio de Figueredo

Comparação de progênies de populaçōes naturais e raças locais de Eucalyptus urophylla S.T. Blake / Horácio de Figueiredo Luz. - Piracicaba, 1997.

191 p. : il.

Dissertação (mestrado) - - Escola Superior de Agricultura Luiz de Queiroz, 1997. Bibliografia.

1. Eucalipto (população) 2. Melhoramento 3. Progênie 4. Seleção I. Título 


\title{
COMPARAÇÃO DE PROGÊNIES DE POPULAÇŌES NATURAIS E RAÇAS LOCAIS DE Eucalyptus urophylla S.T. Blake
}

\author{
HORÁCIO DE FIGUEREDO LUZ
}

Aprovada em : 06 de junho de 1997

Comissão Julgadora:

Prof. Dr. Mário Ferreira

ESALQ / USP

Prof. Dr. Antonio Natal Gonçalves

ESALQ / USP

Prof. Dr. Edson Seizo Mori

FCA - Botucatu / UNESP

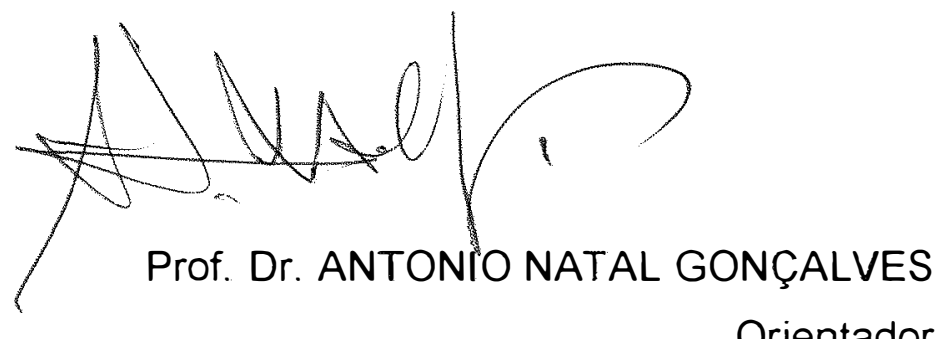

Orientador 
"Ouça um homem de experiência:

E acredita, porque sei,

encontrarás algo muito maior nas florestas que nos livros...

Pedras e árvores te ensinarão

o que não poderás aprender dos mestres! "

Bernard de Claineaux (1090-1153)

One touch of nature make whole world kin.

Shakespeare 
Aos meus pais. Edmundo e Eunice. pela vida. pelo amor. pelo lar e educação. pelas oportunidades e viagens, pelo ensino e exemplo

As avós Ambrosina e Ruth. pela intimidade com a terra. a natureza. o interior e por desde cedo me despertarem Piracicaba como meta

Ao tio Miguel. por todo o apoio. recursos, reflexões. para materializar tantos sonhos e planos

Aos tios Ephraim. Newtone Franklin. por demonstrarem na vida e em suas carreiras a vivência acadêmica. as convicções. a fé. os ideais

À minha querida esposa Ângela. companheira. amiga. colega e sempre namorada Ao muito desejado filho Daniel Que está chegando à luz

\section{$D E D I C O$}




\section{AGRADECIMENTOS}

Muitos colaboraram, muitos são os agradecimentos. Não por mera formalidade, mas porque reconheço que cheguei até aqui contando com amigos. Em especial, relembro e agradeço...

Ao Professor Dr. Antonio Natal Gonçalves, pela orientação, paciência, energia, bom humor e otimismo constantes, harmonizados com incansável vigor nas atividades e um grande senso de justiça e praticidade, demonstrados em horas críticas com muita disposição para enfrentar e mudar a realidade.

Ao Professor Dr. Mario Ferreira, por me apresentar o universo do eucalipto com muita criatividade, intuição, análise crítica contagiante e uma incrivel sede de recuperar a experiência científica e a prática acumulada há muito, para buscar novos avanços e propor desafios que entusiasmam.

Ao Professor Dr. Hilton Thadeu Zarate do Couto, pelo apoio valioso, opinião clara e decidida, pela objetividade e otimismo e ainda pela didática e profissionalismo, exemplificado com muita atividade eficaz que atinge resultados marcantes

Ao Professor Dr. José Leonardo de Moraes Gonçalves, que me orientou em boa parte do tempo, transmitindo princípios de pesquisa e de estudo com rigor e idealismo, fundamentais neste curso.

Aos Professores do Depto. de Ciências Florestais e do Depto. de Solos, em especial Fábio Poggiani, Álvaro Fernando de Almeida e Tsuyoshi Yamada, por transmitirem de forma convincente e embasada os conceitos, as idéias, o conhecimento cumulativo, a visão abrangente, ponderada e realista, tudo isso traduzido em suas próprias experiências de vida. Aos Prof. Drs. Roland Vencovsky do Depto. de Genética e Décio Barbin do Depto. de Matemática e Estatística, pelas importantes sugestões e correções.

Ao colega Eng. Agr. Osmar Beig, na época Gerente Geral de Pesquisa e Desenvolvimento da Eucatex Florestal, que me apoiou, tornando possivel a minha Pós Graduação.

À Eucatex S/A - Divisão Florestal, pela experimentação e cessão dos dados, representada pelos colegas Engs. Luiz Roberto Capitani, Celso José Coutinho e Manoel Carlos Ferreira, que apoiaram e viabilizaram este importante degrau da carreira de pesquisador florestal na empresa, onde espero todo o conhecimento e experiência adquiridos resultem em ganhos de produtividade e eficácia.

Ao colega Richard Bierwagen, pela amizade e preciosa ajuda nas análises estatísticas, na programação em SAS e nas inúmeras revisões dos modelos matemáticos e dos bancos de dados, buscando precisão, exatidão e coerência, com inovação, criatividade e persistência.

Aos colegas Marcelo Brisolla e Emerson Oliveira, por sua amizade, companheirismo e toda ajuda na parte de campo, coleta de dados, viagens e os muitos papos sinceros e divertidos.

A todos os funcionários do Depto de Ciências Florestais e do IPEF, em especial Marialice, Fátima, Margareth, Jeferson, Paulo, Creisa, Magali, Israel, Leonardo, por sua amizade, compreensão, paciência, apoio, rapidez e competência, tornando possível atingir metas, cumprir prazos, realizar o que parecia inatingivel; e nessas oportunidades descobri pessoas fantásticas.

Aos colegas do Curso, pelo apoio, solidariedade, companheirismo e boa companhia, nos minutos dificeis e nos dias de tranquilidade após as conquistas.

A todos que indiretamente participaram nestes últimos anos, meu sincero obrigado. 


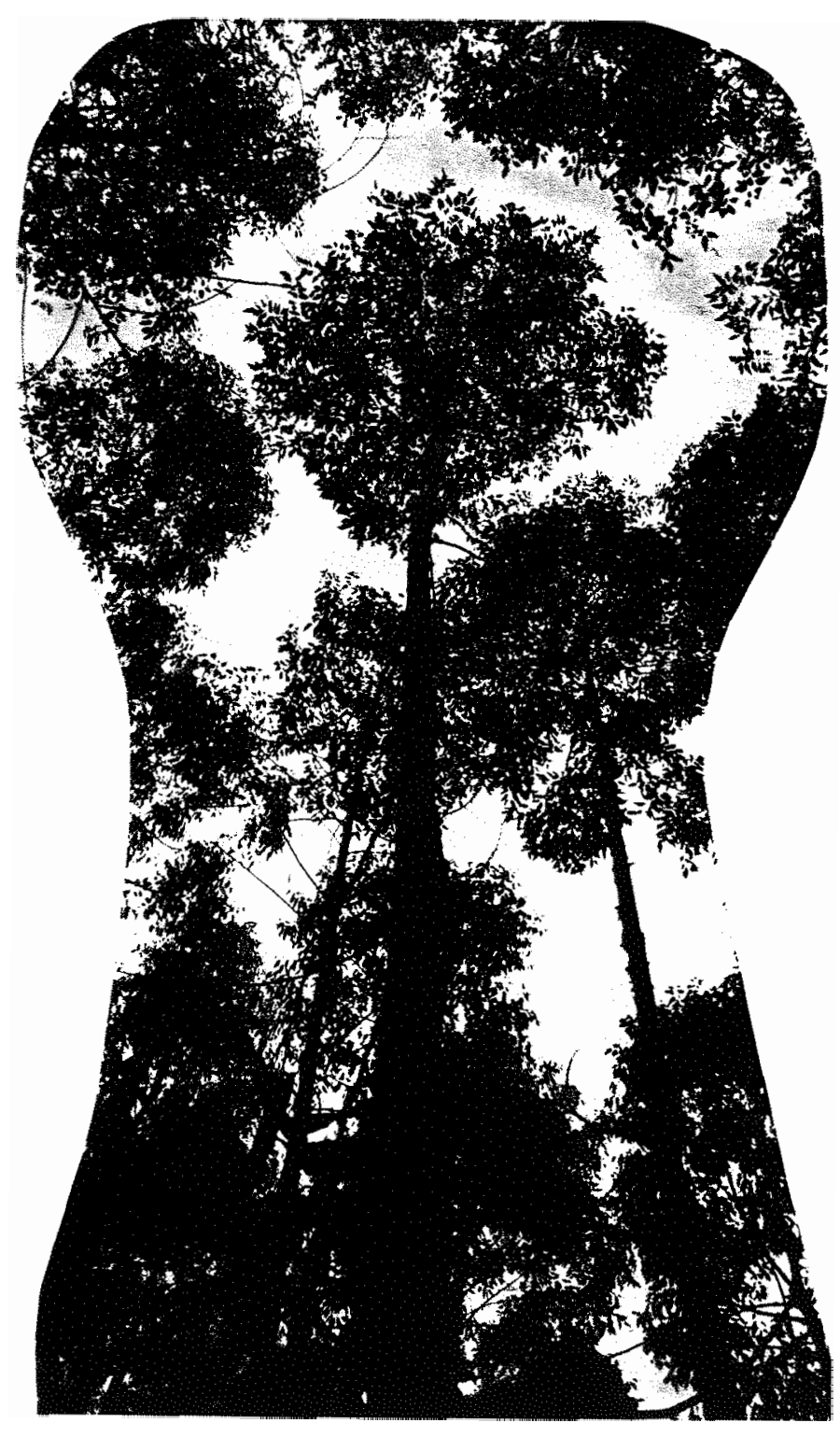

..entre atingir o ideal do céu

e manter-se com os pés na terra,

faça como as árvores...

cresça o quanto for possivel

no lugar e situação

onde estiver...

até mostrar

sol asol,

folha a folha,

passo a passo

todo

o seu

potencial !!!

Horativs, sec I a.c

adaptado 


\section{SUMÁRIO}

LISTA DE FIGURAS E MAPAS ............................................ XI

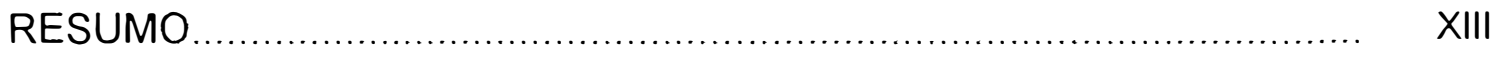

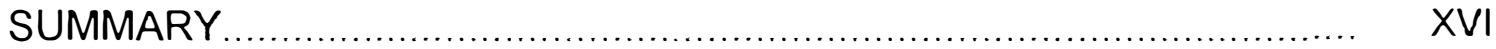

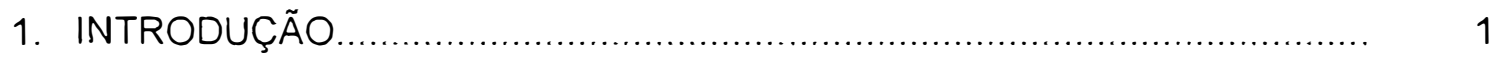

2. REVISÃO DE LITERATURA ............... 4

2.1 Classificação da espécie Eucalyptus urophylla...................................... 4

2.2 Distribuição natural e ecologia de populações......................................... 8

2.3 Procedências de E. urophylla estudadas............................................ 18

2.4 Testes de procedência.................................................................... 25

2.5 Testes de procedência com eucalipto no Brasil................................... 26

2.6 Variação natural e ideotipos em eucaliptos ........................................... 32

2.7 Métodos de seleção para eucaliptos.................................................. 36

3. MATERIAL E MÉTODOS ............................... 44

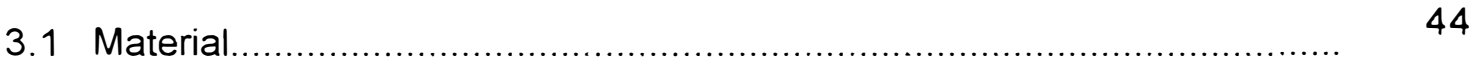

3.1.1 Espécie / Procedências................................................................ 44

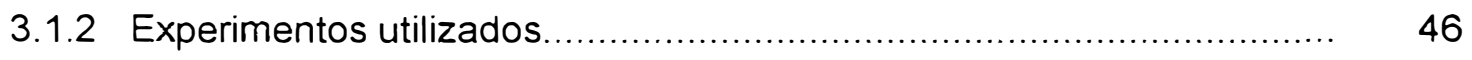

3.1.3 Características edafoclimáticas ..................................................... 46

3.2 Métodos 49

3.2.1 Seleção do material genético.......................................................... 49 
3.2.2 Produção de mudas .................................................................... 50

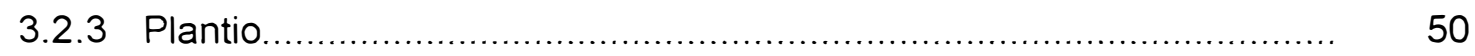

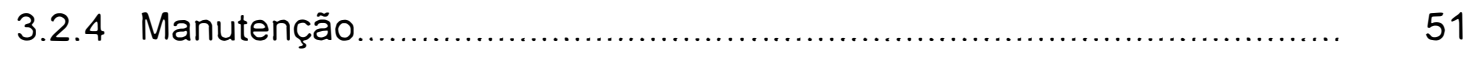

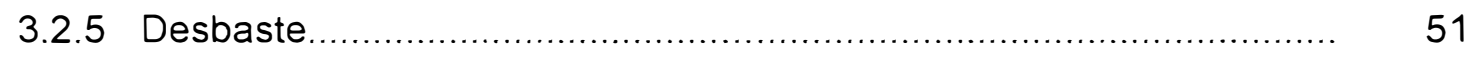

3.2.6 Delineamento estatístico............................................................ 52

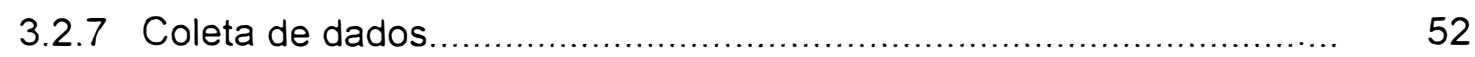

3.2.8 Metodologia para Análise estatística dos dados dendrométricos......... 55

3.2.9 Metodologia da Análise Genética....................................................... 62

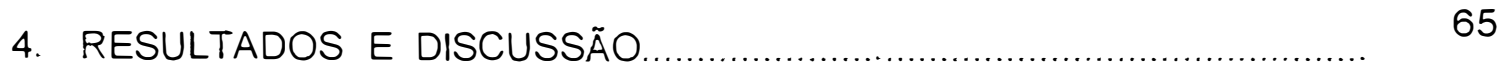

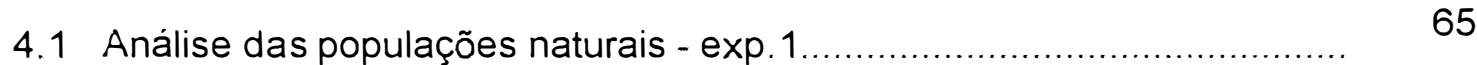

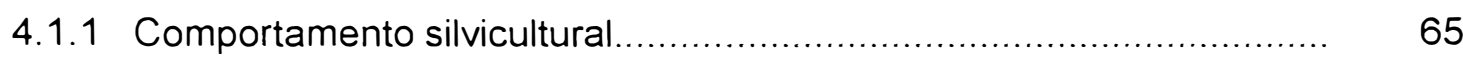

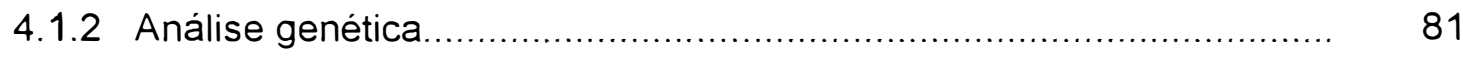

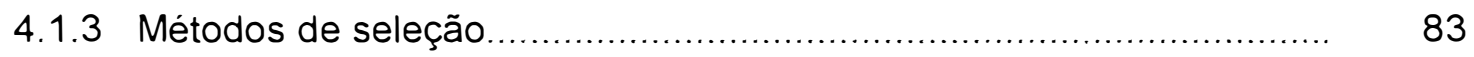

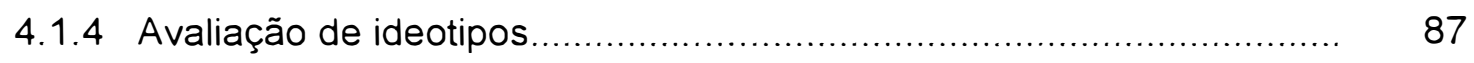

4.2 Análise da população recombinada - exp.2 ….................................... 92

4.2.1 Comportamento silvicultural..................................................... 92

4.2.2 Análise genética................................................................ 100

4.2.3 Seleção de genótipos................................................................... 102

4.2.3.1 Escolha do Método de Seleção................................................... 102

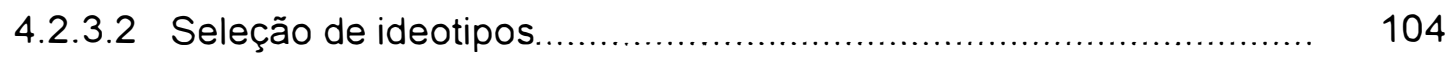

4.3 Estratégia de melhoramento das populações......................................... 108

4.3.1 Comparação silvicultural............................................................... 108

4.3.2 Comparação genética............................................................... 110 
4.3.3 Estratégias para continuidade.......

5. CONCLUSÕES.

REFERÊNCIAS BIBLIOGRÁFICAS.

BIBLIOGRAFIA RECOMENDADA.

ANEXO 1 - Tabelas completas com dados por progênie.

ANEXO 2 - Listagens com classificação das progênies (Teste REGWF)

ANEXO 3 - Resumo da análise confirmatória

APÊNDICE 1 - Descrição das populações naturais ( compilado)

152

APÊNDICE 2 - Fotografias dos experimentos estudados. 


\section{LISTA DE FIGURAS E MAPAS}

FIGURAS :

pág.

Figura 1 - Características morfológicas de Eucalyptus urophylla na região de 10 origem - ilhas Sonda, Indonésia. As fotos mostram exemplar característico da região montanhosa de Timor, acima de $1.000 \mathrm{~m}$ de altitude.

Figura 2 - Disposição das populações naturais de $E$. urophylla e E. alba na região de ocorrência nas Ilhas Sonda. Indonésia, em função da topografia e do solo.

Figura 3 - Ilha Krakatoa na Indonésia, onde em menos de 70 anos a sucessão 16 natural está regenerando a floresta em torno do vulcão que continua ativo.

Figura 4 - Efeito orográfico em áreas montanhosas de ocorrência natural de $E$. urophylla nas ilhas Flores, Timor e outras do arquipélago de Sonda, Indonésia.

Figura 5 - Gráfico de volume das progênies da procedência llha Flores (exp.1), 86 evidenciando as respostas diferenciadas 2 anos após o desbaste. E urophylla, Bofete, SP.

Figura 6 - Gráfico de volume das progênies da procedência Outras llhas (exp.2), evidenciando as respostas diferenciadas 2 anos após o desbaste. E urophylla, Anhembi, SP.

MAPAS :

pág.

Mapa 1 : Área de ocorrência natural de Eucalyptus urophylla na Indonésia e formações vegetais. Fonte: Atlas of Oceania and Australia, Sydney University.

Mapa 2 : Área de ocorrência natural de Eucalyptus urophylla nas ilhas Sonda. Indonésia. Segundo Martin \& Cossalter (1975). 
Mapa 3 : Populações naturais de E. urophylla coletadas na Ilha Flores, Indonésia, como procedências (Martin \& Cossalter, 1975).

Mapa 4 : Localização dos experimentos com E. urophylla em Bofete e Anhembi 48 - SP.

Obs: as figuras e os mapas do apêndice não estão numerados de acordo com esta lista. 


\title{
COMPARAÇÃO DE PROGÊNIES DE POPULAÇÕES NATURAIS E RAÇAS LOCAIS DE Eucalyptus urophylla S.T. Blake
}

\author{
Autor: HORÁCIO DE FIGUEREDO LUZ \\ Orientador: Prof. Dr. ANTONIO NATAL GONÇALVES
}

Co-Orientadores: Prof. Dr. Mario Ferreira

Prof. Dr. Hilton Tadeu Z. do Couto

\section{RESUMO}

O Eucalyptus urophyila S.T.Blake é uma das espécies de eucalipto mais plantadas no Brasil, devido à utilização de sua madeira nas indústrias de celulose, papel, chapas, carvão, serrarias, postes e ocupação de áreas degradadas.

É uma espécie com grande potencial de adaptação a ambientes variados, desde as regiões tropicais úmidas até as sub-tropicais, devido à sua amplitude de ocorrência natural em altitudes. Possui boa produtividade e é tolerante a doenças, comuns nos trópicos. Estima-se em mais de 400.000 ha a área plantada com este eucalipto, principalmente no sudeste brasileiro, sendo também muito utilizado seu hibrido com E. grandis.

O E. urophylla ocorre em populações selvagens nas ilhas Flores, Pantar, Adonara, Alor, Loblem, Wetar e Timor, na Indonésia, colonizando uma grande região marcadamente vulcânica, instável e com intensa fragmentação e isolamento entre as populações. No leste da ilha Flores ocorre circundando os vulcões Egon e Lewotobi, em densas populações na borda da floresta tropical mista, em sítios férteis. $O$ resultado adaptativo ao ambiente muito variável, após milhares de gerações, são as significativas variações fenotipicas, que envolvem ainda a coexistência com a espécie E. alba, muito próxima taxonomicamente e que pode hibridar com E. urophylla. 
O E. urophylla apresenta polimorfismo acentuado, o que sempre dificultou sua descrição. Por isso tem sido realizados estudos sobre o desenvolvimento das populações já introduzidas e melhoradas nos trópicos, estabelecendo bases corretas para aproveitar todo o seu grande potencial adaptativo e sua aptidão para hibridação e para usos múltiplos.

Este trabalho tem por objetivos caracterizar três populações de E. urophylla em duas gerações ( $F_{0}$ e $F_{1}$ ), comparando suas progênies, para selecionar as árvores superiores em volume de madeira e formar Pomares de Sementes por Mudas que atendam o programa de melhoramento da espécie, equilibrando adequadamente os maiores ganhos de produtividade com perdas aceitáveis da base genética.

Foram estudados dois experimentos, antes e após um desbaste seletivo, em Bofete (populações selvagens $F_{0}$ da llha Flores - Egon e Lewotobi) e Anhembi (população melhorada $F_{1}$, oriunda da recombinação de Outras llhas da Indonésia), ambos sobre solos arenosos na região central do estado de São Paulo. Estes dois testes de progênie foram instalados no delineamento de blocos casualizados, com parcelas lineares e quatro repetições.

Os dados de altura, diâmetro, volume, falhas e tipo de casca foram submetidos à análise de variância através dos testes $F$ e REGWF para comparação múltipla de médias. Para controlar e avaliar o efeito do desbaste seletivo que provoca forte desbalanceamento, aumentando o efeito ambiental, foi adicionado ao modelo estatístico a interação blocos $x$ progênies. Entre as procedências foi aplicada a técnica de contrastes lineares (Proc GLM - SS3) para comparação das progênies.

As variâncias genéticas e fenotípicas e os componentes de variância para volume foram estimados pelo método REML.. Foram também determinados os coeficientes de herdabilidade, intensidade de seleção e ganho genético para três métodos de seleção: massal, sequencial e combinada com indice, todos adotando limites de seleção com base no desvio padrão populacional.

Com base nos resultados obtidos para as idades entre 3 e 6 anos, concluiu-se que há diferenças significativas entre procedências, e entre progênies para as procedências Lewotobi e Outras Ilhas. Estas possuem os maiores valores de DAP, 
altura e volume estimado, bem como obtiveram maior ganho genético, com maiores variância genética aditiva e herdabilidades, apresentando portanto maior potencial de melhoramento do que a procedência Egon. As melhores estratégias de seleção, para maximizar ganhos com menor perda da base genética, foram seleção massal para as procedências Lewotobi e para Outras Ilhas. Para a procedência Egon, com menor potencial de melhoramento, a seleção sequencial traz melhores ganhos com redução adequada no número de famílias.

A seleção massal direcionada para o ideotipo casca lisa aumentou sua frequëncia em quase $20 \%$ na geração F1. Foi observado incremento igual ou pouco menor das árvores superiores do ideotipo casca lisa, em comparação às de casca fibrosa ou rugosa, para as populações selvagens $F_{0}$. Na população selecionada $F_{1}$ ocorreu o contrário, com o ideotipo casca lisa apresentando maior crescimento, até $15 \%$ a mais que o ideotipo de casca fibrosa.

Foi observada grande variação morfológica desde a origem para os tipos de casca, sendo estabelecidas três categorias ou ideotipos para classificação, que não apresentaram nenhuma correlação com as progênies.

O efeito do desbaste em um ano reduz acentuadamente as variâncias genéticas e as herdabilidades. Entretanto, após 2 anos, os valores das variâncias aumentam muito mais do que de antes, enquanto as herdabilidades foram retornando à normalidade, indicando que a competição entre plantas está voltando a estratificar as árvores, expressando diferencialmente seu potencial genético. $O$ desbaste seletivo influencia mais as estimativas absolutas dos componentes de variância e das herdabilidades, do que sua proporção em relação ao total.

O melhoramento das populações após a recombinação mostra-se mais eficiente, podendo ser aproveitado um leque muito mais amplo de indivíduos, que é demonstrado pela comparação de superioridade das médias das melhores progênies sobre as piores; aos 5 anos, em Flores é de $24 \%$ e em Outras Ilhas atinge $56 \%$. 


\title{
COMPARISON AMONG PROGENIES OF POPULATIONS AND LAND RACES OF Eucalyptus urophylla S.T.Blake
}

\author{
Author: HORACIO DE FIGUEREDO LUZ \\ Adviser: Prof. Dr. ANTONIO NATAL GONÇALVES
}

\section{SUMMARY}

Eucalyptus urophylla is one of the most planted eucalypts in Southast of Brazil, with more of 400.000 ha reforested area. It shows high silvicultural performance, good adaptation to dry seasons and warm climate conditions and very good survival of sprouts after clear cutting. Its hybrids with E. grandis, by seeds or clonal propagation, are very important to Brazilian wood production.

E. urophylla is found in wild populations at indonesian islands Flores, Pantar, Adonara, Alor, Lomblem, Wetar and Timor, covering a large unstable volcanic region with great fragmentation and isolation among populations. In West Flores Is. Occours surrounding the Egon and Lewotobi volcanoes in the border of rainforest over fertile soils. The adaptation to very variable environmental conditions after thousand generations results on great phenotypical variations that include hybridization with a related species $E$. alba.

That species shows a great polymorphism difficulting its description. Therefore, studies about the population ammeliorated in the tropical regions have been done to stablish correct embasement to use the whole great adaptative potencial and ability for hybridization and multiple uses.

The objectives of this work were to characterize the phenotypic and the genetic variations of three base populations of Eucalyptus urophylla S.T.Blake from Indonesia 
(Flores and Other Islands) comparing progenies and selecting plus trees trying different improvement methods, and to verify the importance of the gumbark tree type for the improvement.

Two base populations provenance/ progeny trial of $E$. urophylla established over sandy soils since 1990 at Anhembi and Bofete - SP, were studied: Flores Island from Mt. Egon and Mt. Lewotobi ( wild progenies) and Adonara, Pantar and Wetar islands = Other Islands ( progenies selected for gumbark), both in randomized block statistical design with 4 replications and 8 plants by row plot. The trials were studied before and after a thinning and this influence over the growth is presented.

At three ages the dendrometric and genetic parameters are discussed for these populations on that two breeding generations. The height, $\mathrm{DBH}$ and volume per tree data was analyzed in F and REGWF tests using SAS. Among provenances the linear contrast ( proc GLM - ss3 ) to match progenies was applied.

The phenotypical and genetic variances were estimated with REML method. The heritabilities, selection intensity and genetic gains were calculated by three selection methods: mass, sequencial and combined with index, all adopting selection limits based on populational standard deviation.

The results have statistic significances for all comparisons within each population. The best means for $\mathrm{DBH}$, height and volume were obtained for Lewotobi provenance followed by Other Islands. In the same way both provenances had bigger genetic gain, additive genetic variance and heritabilities, therefore showing greater improvement potencial than Egon provenance.

There was great morphologic variation from origin for bark types, and it were stablished three classes or ideotypes for the classification and it shown no correlations with the progenies.

Different selection strategies were proposed to maximize genetic gains with smaller genetic base decrease. The mass selection for gumbark type increase its frequency by $20 \%$ between generations. There is equal volume increase for the fibrousbark and the gumbark tree types in the wild materials, but the opposite was 
occurred in selected population whose gumbark type had best growth with $15 \%$ more. This importance and implications for improvement are discussed.

The thinning effect by one year decrease so much the genetic variances and heritabilities, however after 2 years the variances enlarges much more than before while heritabilities were returning to normality, indicating that competition among trees is ranging they. The selective thinning influence more the absolute variance components and heritabilities than its proportion.

The restrictions to usual applications to genetic estimates as heritabilities and quantitative genetic parameters applications are commented, and the importance and implications for improvement of the gumbark type is presented. The improvement after recombination is more efficient with more advantage of the better trees that shown superiority of 24 to $56 \%$ in the averages of the best progenies over the worst. 


\section{1 - INTRODUÇÃO}

O Eucalyptus urophylla, introduzido em 1919 em S.Paulo como E. alba, é uma das 4 espécies de eucalipto mais plantadas no Brasil, devido à sua utilização nas indústrias de celulose, papel, chapas, carvão, serraria, postes etc, estimando-se que exista hoje uma área plantada ao redor de 300.000 ha.

Pela sua amplitude de ocorrência em altitudes e ambientes variados, é considerada uma espécie silviculturalmente muito importante, pois oferece um potencial de adaptação muito amplo, desde as regiões tropicais úmidas até as subtropicais, especialmente na produção de híbridos.

O E. urophylla ocorre em populações selvagens com ampla distribuição altitudinal em variados ambientes nas ilhas Flores, Timor, Pantar, Adonara, Alor, Lomblem e Wetar, na Indonésia. Recentemente foram descritas duas novas espécies que coexistem com esta, que são E. orophylla e E. wetarensis (Pryor, 1995) além do contato com E. alba em muitas procedências ( Martin \& Cossalter,1975). Estes fatos de grande variabilidade ambiental e genética contribuem para significativas variações fenotípicas.

A espécie Eucalyptus urophylla S.T. Blake é um dos eucaliptos mais plantados no Brasil, juntamente com E. grandis, E. saligna e E. camaldulensis. Em sítios de alta produtividade, ele produz um pouco menos do que os dois primeiros. Porém, apresenta uma rusticidade bem maior e uma capacidade de adaptação muito melhor a ambientes adversos. Isto é devido à melhor eficiência nutricional e hídrica, por possuir mecanismos fisiológicos, foliares e radiculares resultantes de um longo processo de adaptação ao ambiente ecológico da sua região de origem.

Além disso, características de arquitetura de copa e alta capacidade de rebrota por lignotubérculo conferem ao E. urophylla uma posição ímpar como alternativa para 
o melhoramento, visando reflorestamentos em áreas onde as espécies tradicionais encontram sérias limitações de adaptação ao clima e ao solo.

Uma fonte de variabilidade natural da espécie, extremamente importante para ser selecionada em programas de melhoramento, é a presença de árvores distintas do tipo predominante, quase uma variedade de casca lisa e clara, muito frequente, que destaca-se em meio à casca rugosa e escura característica das populações de $E$. urophylla.

Eses individuos com casca lisa têm sido denominados de E. urophylla "variedade platyphylla " ou simplesmente E. platyphylla. Entre eles, existem sempre árvores dominantes extremamente vigorosas e com crescimento superior às melhores árvores da espécie pura ou de outras espécies vizinhas. Alguns importantes programas de clonagem operacional de grandes empresas estão baseados exatamente neste tipo de material, que acaba sendo considerado como um híbrido natural ou espontâneo.

Segundo vários autores, os individuos de E. urophylla oriundos da llha Flores são muito diferentes daqueles da Ilha Timor. Nesta ilha ele apresenta características uniformes de folhagem, casca e frutos, enquanto em Flores há uma grande desuniformidade nestas caracteristicas entre os individuos.

As árvores de E. urophylla da ilha Timor apresentam tronco recoberto por uma casca rugosa até a extremidade dos galhos; já em Flores a casca rugosa às vezes inexiste ou ocorre em variadas proporções desde a base até todo o tronco.

Também há a hipótese de haver duas varidades separadas pela altitude : a variedade com casca fibrosa (em maiores altitudes), e a com casca lisa (em médias altitudes), a qual ocorre principalmente na ilha Flores.

A "variedade" com casca lisa também é conhecida como $E$. platyphylla, sendo suposta por alguns como um possivel hibrido de $E$. alba $\times$ E. urophylla, pois o $E$. alba também ocorre nestas altitudes, só ou associado ao E. urophylla. Deve ser considerada, ainda, a possibilidade de introgressão entre as espécies.

Porém esta questão não está bem resolvida por falta de maiores evidências, sendo que os possiveis hibridos na llha Flores não diferem de individuos onde a 
procedência é pura; já em Timor, os possiveis hibridos possuem características intermediárias entre o E. alba e o E. urophylla.

\section{- OBJETIVOS}

- Caracterizar silviculturalmente duas populações de E. urophylla, sendo uma de material selvagem colhido na origem ( 2 populações da llha Flores, geração inicial de introdução $-F_{0}{ }^{*}$ ) e a outra resultante de colheita seletiva de árvores casca lisa clara numa $F_{0}$ originária de Outras Ilhas da Indonésia (Alor, Pantar, Lomblem e Adonara), o que corresponde à $1^{\underline{a}}$ geração de seleção ( ou $F_{1}$ ).

- Determinar a variabilidade natural, entre procedências e entre progênies, para parâmetros dendrométricos e fenotípicos (padrões de ideotipos), inferindo as influências dos ideotipos no melhoramento da espécie.

- Analisar os parâmetros genéticos e fenotípicos obtidos através de três métodos de seleção de árvores superiores (massal, sequencial e combinada) para equilibrar ganho genético e tamanho efetivo populacional.

- Selecionar os melhores fenótipos, que permitam maiores ganhos genéticos em produtividade e qualidade nas próximas gerações.

\footnotetext{
1 Preferida a grafia $\mathrm{F}$ para designar as gerações, por ser adotada em toda a literatura florestal, ao invés de $C$, que é encontrada em outras situações agrícolas.
} 


\section{2 - REVISÃO DE LITERATURA}

2. 1 - Classificação da Espécie Eucalyptus urophylla

O Eucalyptus urophylla S.T. Blake ocorre naturalmente na Indonésia, onde tem o nome popular de ampupu, numa faixa compreendida entre $7^{\circ} 30^{\prime}$ e $10^{\circ}$ de latitude Sul e de $127^{\circ}$ a $122^{\circ}$ de longitude Leste, englobando as ilhas de Flores, Adonara, Alor, Pantar, Lomblen, Wetar e Timor (Martin \& Cossalter, 1975).

Estas ilhas fazem parte do arquipélago de Sonda na província de Nusa Tenggara Timur, Indonésia, na transição entre Oceania e Ásia ( ver mapa 1 ). Está associado ao E. alba Reinw em todas essas ilhas.

De acordo com revisão apresentada por Pryor (1995), o E. urophylla recebe a seguinte classificação ( definida por Pryor e Johnson, 1971 e revista em 1981):

$\begin{array}{ll}\text { espécie: } & \text { Eucalyptus urophylla } \\ \text { subsérie } & \text { Resiniferinae } \\ \text { série } & \text { Salignae } \\ \text { seção } & \text { Transversaria } \\ \text { subgênero } & \text { Symphyomyrtus } \\ \text { gênero } & \text { Eucalyptus }\end{array}$


Recentemente a espécie foi reestudada (Pryor, 1995) e, devido a diferenças marcantes entre populações, foi dividida em 3 espécies, permanecendo:

E. urophylla para designar o material deste estudo e sendo criadas as novas

E. orophylla ( somente na llha Timor) e

E. wetarensis ( só na llha Wetar).

Há outras espécies consideradas como muito próximas e aparentadas, todas da mesma série, sendo bastante semelhantes na aparência, morfologia, folhas, frutos e madeira. São elas:

E. pellita F.Muell

E. resinifera Smith

E. notabilis Maiden

E. scias Jonhson \& K. Hill

Há ainda mais algumas novas espécies assemelhadas não descritas, do norte da Austrália e da Nova Guiné, conforme Pyniopusarerk (1993) e Pryor (1995).

Este grupo é denominado popularmente como "Red mahoganies" ou mognos vermelhos, ou também mognos australianos, pela alta qualidade de sua madeira, 0 que concorre para intensa exploração desde o século passado, destruindo ou perturbando as populações naturais dessas espécies. 


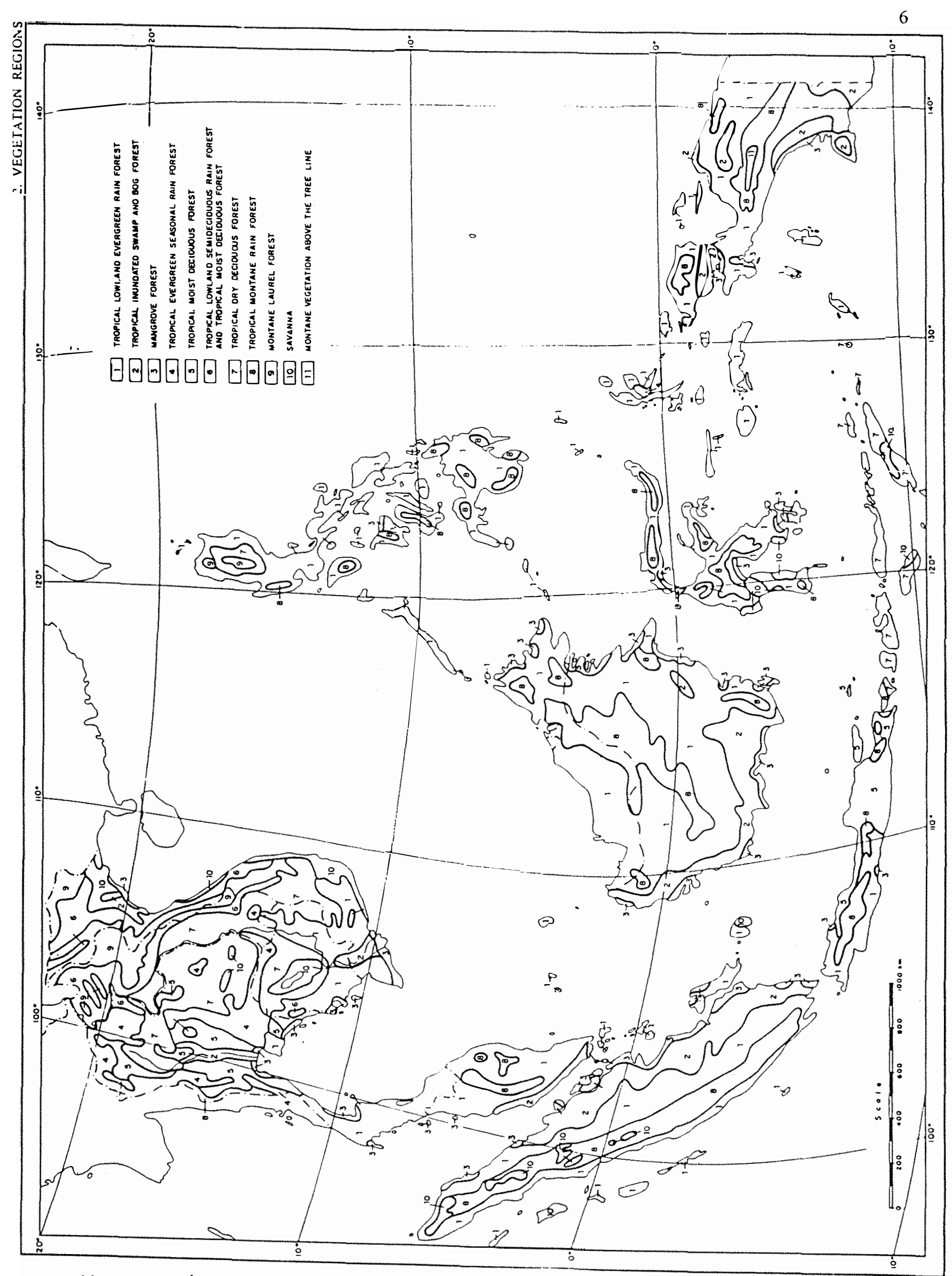

Mapa 1 - Área de ocorrência natural de Eucalyptus urophylla na Indonésia e formações vegetais. Fonte: Atlas of Oceania and Australia. Sydney University. 
Uma revisão abrangente sobre a classificação da espécie é apresentada por Brasil (1983), sendo parte de seus comentários citados ou modificados a seguir, intercalados com trechos de outros autores consultados.

O E. urophylla está classificado incorretamente em diversos locais onde foi introduzido. Uma árvore centenária, oriunda da llha Flores e plantada no Jardim Botânico de Bogor em Java, está etiquetada como E. alba, antiga denominação holandesa. Na Indonésia, ex-colonia da Holanda, o verdadeiro $E$. alba foi denominado E. platyphylla e o E. urophylla como E. alba (Martin \& Cossalter, 1975).

Até 1972, o nome usado pelos pesquisadores australianos para o $E$. urophylla foi $E$. decaisneana quando, após uma viagem de Pryor à região e posterior descrição da espécie por Blake, adotou-se definitivamente o nome de Eucalyptys urophylla S.T. Blake (FAO, 1981).

Estas informações são essenciais para consultar trabalhos científicos mais antigos, onde ocorrem enganos na denominação. No Brasil, o E. urophylla era indevidamente denominado E. alba Reinw ex Blume (Eldridge, 1976, citado por Brasil, 1983). Por isto, Martin \& Cossalter (1975) sugeriram usar "alba do Brasil" para o material classificado como E. alba, procedência Rio Claro - SP ( Horto da antiga Cia. Paulista de Estradas de Ferro, hoje FEPASA), cujas sementes resultaram, na maior parte, em mais de 200.000 ha de bons reflorestamentos, com ótima capacidade de rebrota, especialmente sobre solos mais pobres, arenosos ou secos, como os de cerrado.

Muitos desses plantios apresentaram hibridação não controlada de E. urophylla com E. tereticornis, E. robusta, E. saligna e outras espécies, segundo Pryor (1971). A forma mais adequada para citar esse material seria E. urophylla, hibrido de Rio Claro. Este material hibrido, segundo Brasil (1986), como as procedências Casa Branca e Camaquã ( também de Rio Claro - SP ), foi submetido ao sistema de seleção por árvores brasões, ou porta-sementes, onde um exemplar isolado era eleito como excelente e dele se colhiam regularmente muitos quilos de sementes para plantios extensos. 
$\mathrm{Na}$ época eram desconhecidos os problemas decorrentes da endogamia e autofecundação em eucaliptos, e a hibridação presente nesse material agravou os inconvenientes do uso continuado desse material. Isso resultou em perdas de produtividade e uniformidade ao longo de algumas gerações, de acordo com Mora e Ferreira (1978), que alertaram para a limitação no potencial do $E$. urophylla pela base genética restrita, hibridações não controladas e depressões genéticas motivadas pelo intenso comércio de sementes de plantios híbridos.

A partir da década de 1970, a solução foi tornar a introduzir materiais selvagens, colhidos na origem com critérios científicos, buscando uma base genética ampla e trabalhando adequadamente esses genótipos na forma de populações base e testes de procedência e progênie, conforme relatam Vieira e Bucsan (1977) e Silveira (1986).

2. 2 - Distribuição natural e ecologia de populações

$\mathrm{Na}$ região de origem, há diferenças morfológicas fundamentais entre as duas espécies em questão, consideradas típicas. Nas diversas ilhas do arquipélago de Sonda, o E. urophylla é uma árvore de grande porte, atingindo mais de $50 \mathrm{~m}$ de altura, representativa de florestas altas, com tronco reto, fuste sem tortuosidade, com dominância apical; possui casca fibrosa escura e folhas lanceoladas, terminando em ponta afiladas ( daí o termo "uro" em latim, cauda ), conforme mostrado na figura 1.

A forma típica da espécie, segundo Boland et al. (1994) é a encontrada em Timor e Outras Ilhas, possuindo na Austrália uma variedade descrita como E. alba var. australasica. Em locais muito férteis e favoráveis, o autor cita que pode atingir mais de $20 \mathrm{~m}$ de altura e $70 \mathrm{~cm}$ de DAP, mas com fuste reto só até a metade da árvore.

O E. alba é uma arvoreta de pequeno porte, tortuosa, copa simpodial sem dominância apical, com folhas largas arredondadas e com casca lisa e branca (origem 
do nome ), ocorrendo em savanas e nos woodlands ( cerrados de eucalipto ) nas mesmas ilhas citadas, e também na Nova Guiné e no norte e noroeste da Austrália (ver figuras no apêndice), conforme Martin e Cossalter (1975).

O E. alba Reinw. ex Blume pertence à seção Exsertaria, série Albae, subsérie Albinae e inclui o antes chamado E. platyphylla F. Muell. e suas variedades platyphylla e tintinnans, que são consideradas hoje apenas variações naturais das populações do E. alba em sua ampla região de ocorrência, mais abrangente do que $E$. urophylla , que não ocorre na Austrália ( Boland et al. 1994 e Brooker \& Kleinig, 1995).

O cruzamento entre as duas espécies pode ocorrer com facilidade, considerando que as épocas de floração chegam a ser coincidentes, de junho a outubro, com o E. urophylla iniciando o florescimento mais cedo (ver mapa no apêndice). Mas na região de origem os híbridos não são muito comuns, pois ocupam diferentes áreas ecológicas e nos trechos de contato entre as duas espécies, as épocas de floração muitas vezes são diferenciadas ( Martin \& Cossalter, 1975 ). Estes autores encontraram a maior porcentagem de hibridos naturais em Timor Leste, com árvores apresentando porte de E. urophylla e folhas e casca como as do E. alba. Admitiram dois tipos de hibridos, devido a outras caracteristicas de crescimento como dominância apical e arquitetura de copa (ver apêndice com fotos).

As possibilidades de hibridação entre os eucaliptos são discutidas por Griffin et al. (1988), que ressaltam que formas intermediárias encontradas hoje podem ser remanescentes de uma antiga variação clinal que conectava duas espécies, atualmente ilhadas. Citam também que a pressão evolucionária poderia levar a que uma espécie assumisse atributos fenotípicos de outra, sem no entanto ter ocorrido uma real hibridação. Destacam também a grande importância do aproveitamento dos híbridos ou de populações hibridas para o melhoramento, como forma de obter adaptação com altas produtividades, exemplificando com o hibrido "urograndis" do Brasil , ou $E$. grandis $X E$. urophylla, um exemplo mundial de sucesso silvicultural.

Ainda Martin e Cossalter (1975), após expedição detalhada ao arquipélago de Sonda, sugerem a existência de duas variedades de E. urophylla separadas por altitudes, com a variedade de casca lisa sendo comum nas menores altitudes, principalmente na ilha Flores. 


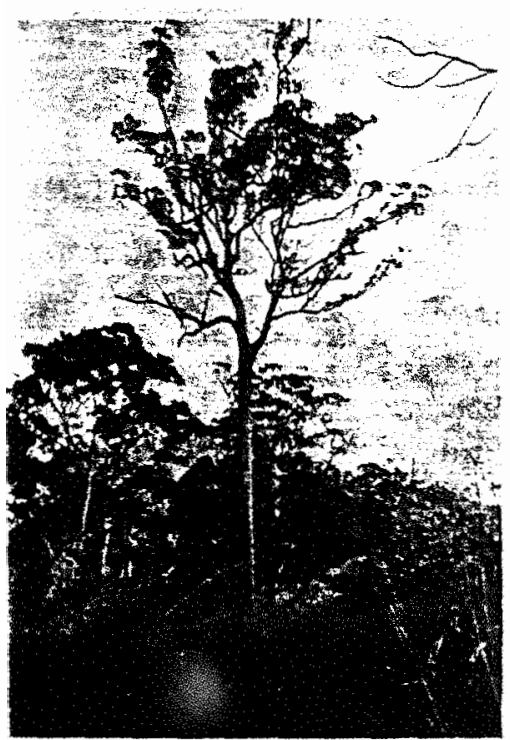

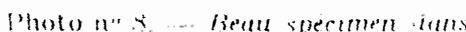

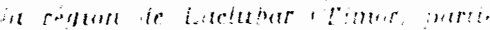
(unringuise)

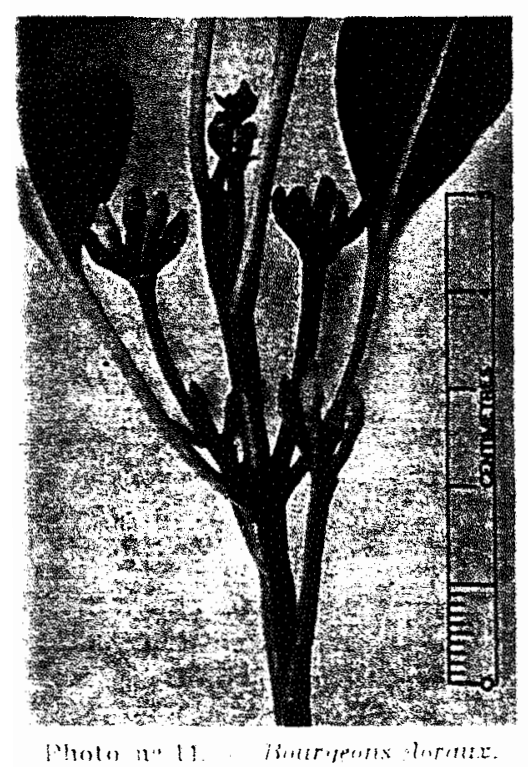

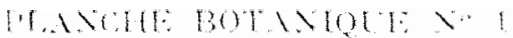

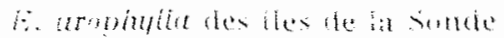

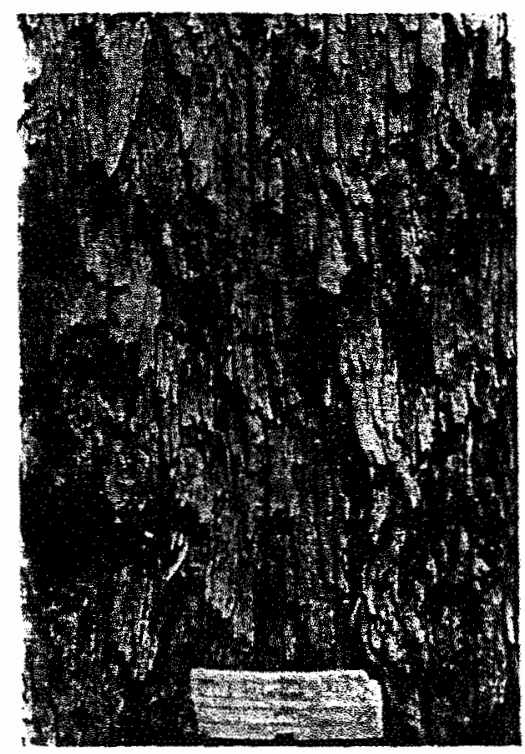

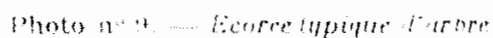

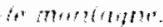

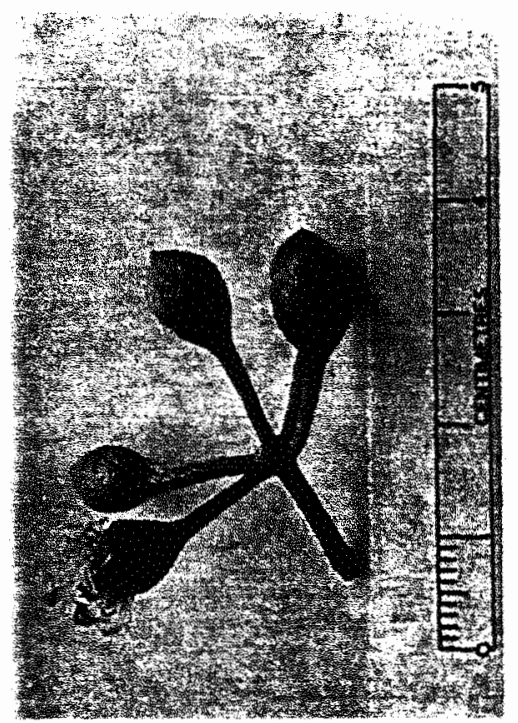

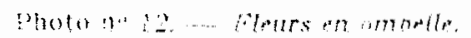

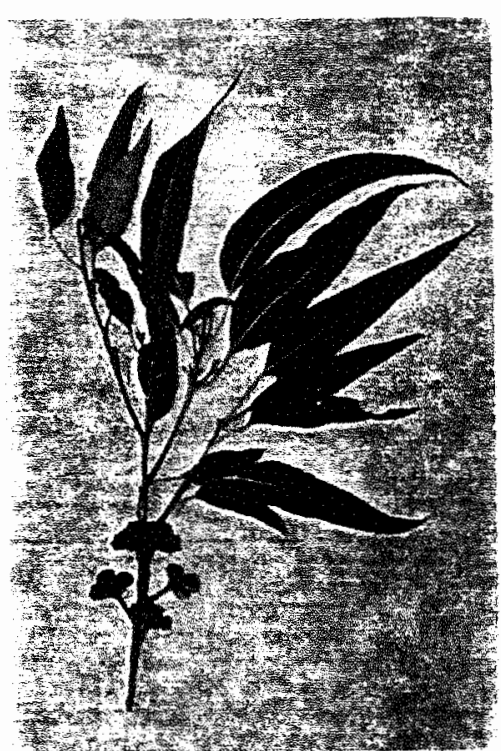

Photo: 11" 11 . Echantillon lype le foulles il te rouls.

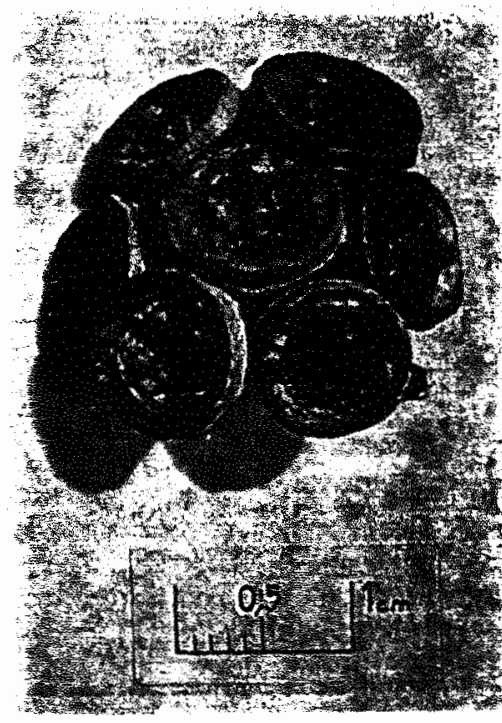

Photo a. 13. tilomerule te fruils.

Photen ti. sailter

Figura 1 - Caracteristicas morfologicas de Eucalyptus urophylla na região de origem - ilhas Sonda. Indonésia. As fotos mostram exemplar caracteristico de região montanhosa de Timor acima de $1000 \mathrm{~m}$ de altitude $\mathrm{Na}$ sequência árvore adulta: casca fibrosa, ramo com folhas e frutos: botões floraıs: detalhe de uma umbela floral frutos. Segundo Martin e Cossalter (1975) 


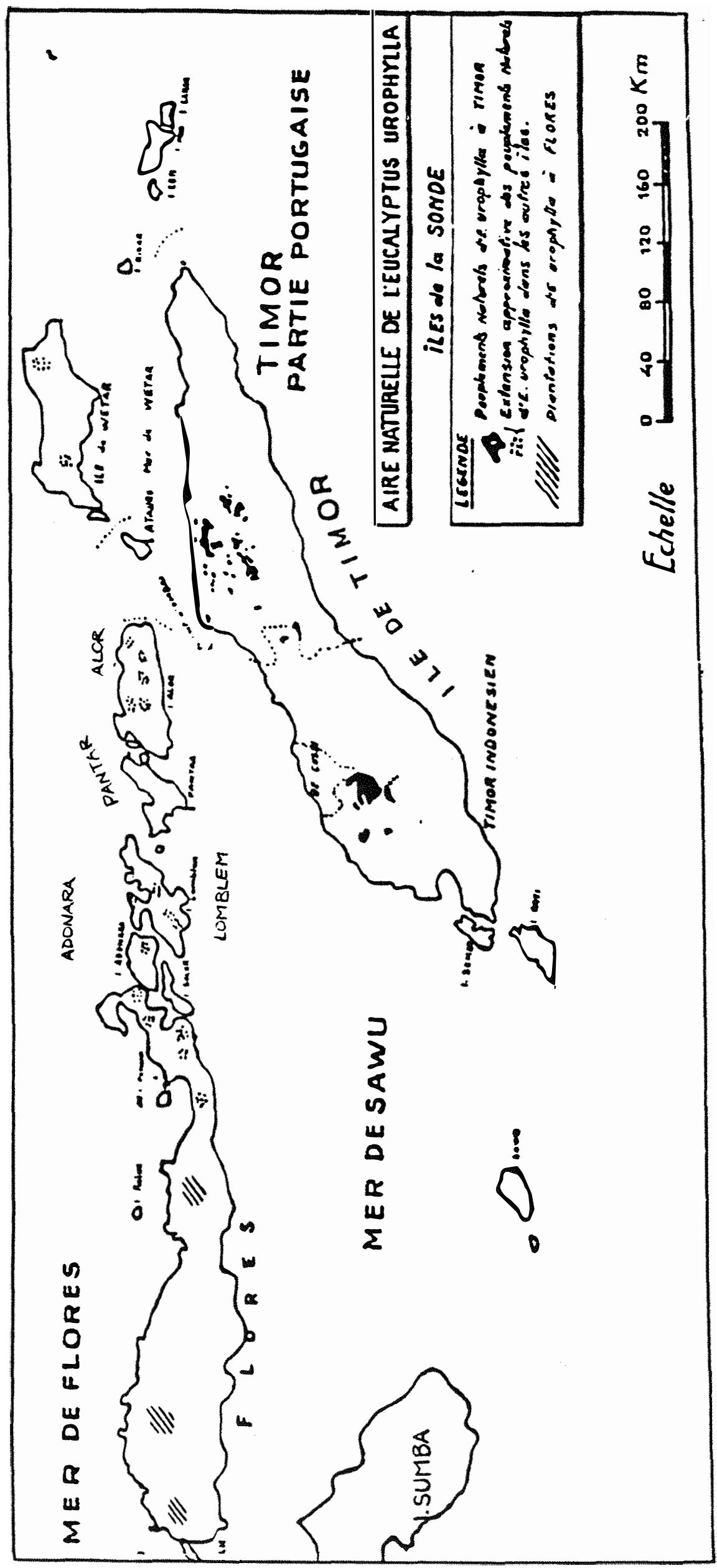

11

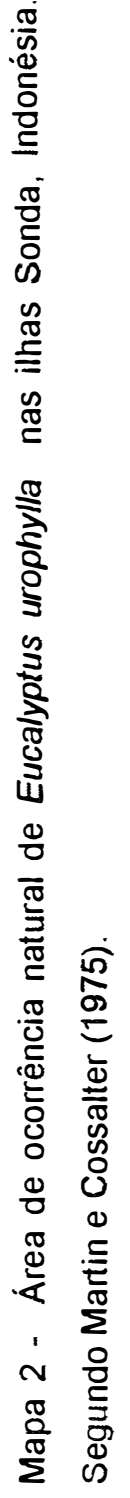


É possivel inferir da descrição morfológica das duas espécies em função da altitude, que há caracteristicas comuns em altitudes médias entre 600 e $1200 \mathrm{~m}$, que são consideradas baixas para o E. urophylla e altas para o E. alba. A figura 2 ilustra a distribuição das duas espécies conforme as condições do sítio.

Como comentado por Brasil (1983), existe o possivel fenômeno da introgressão do E. alba no E. urophylla, o que levaria a grandes diferenças de comportamento entre populações que apresentam aptidões ecológicas distintas (Anderson, 1968).

Essa hipótese é possivel e muito provável para explicar a ocorrência de materiais distintos da maioria da população. Seria a influência introgressiva do $E$. alba na população de $E$. urophylla em diversas épocas, há centenas de gerações passadas, em repetidas vezes, com esta incorporando genes da outra espécie, num processo de hibridação e retrocruzamentos (Anderson, 1968). Muitos desses genes controlam somente características morfológicas, sem correlação com a produtividade ou nenhuma vantagem adaptativa diante da pressão de seleção ambiental.

Isto é indicado por trabalhos como o de Gouvêa et al.( 1997), que estudaram características dendrométricas e composição química da madeira de $E$ urophylla, procedências originadas de Mt. Egon e recombinada de Flores, comparando 3 proporções de casca rugosa persistente no tronco - entre 0 , 25, 75 e $100 \%$. Concluíram que há maior diferença entre procedências do que entre os tipos de casca, e que a seleção com base na porcentagem de casca não foi eficiente para indicar produtividade nem qualidade da madeira. Não informam, porém, a frequência dos tipos de casca nas populações estudadas, nem fazem sua descrição.

Luz et al. (1996) não encontraram diferenças de crescimento entre tipos de casca para populações selvagens de E. urophylla da llha Flores. Apesar de grandes diferenças morfológicas, as produtividades foram as mesmas aos 4 anos para árvores de casca lisa ou fibrosa. No mesmo trabalho, porém, apresentam superioridade do ideotipo de casca lisa em populações recombinadas e selecionadas ( raça local), indicando que a estratégia de seleção pode influir significativamente nos resultados.

É fundamental, portanto, entender e caracterizar esses genótipos para atender aos programas de introdução e melhoramento da espécie em paises tropicais. 


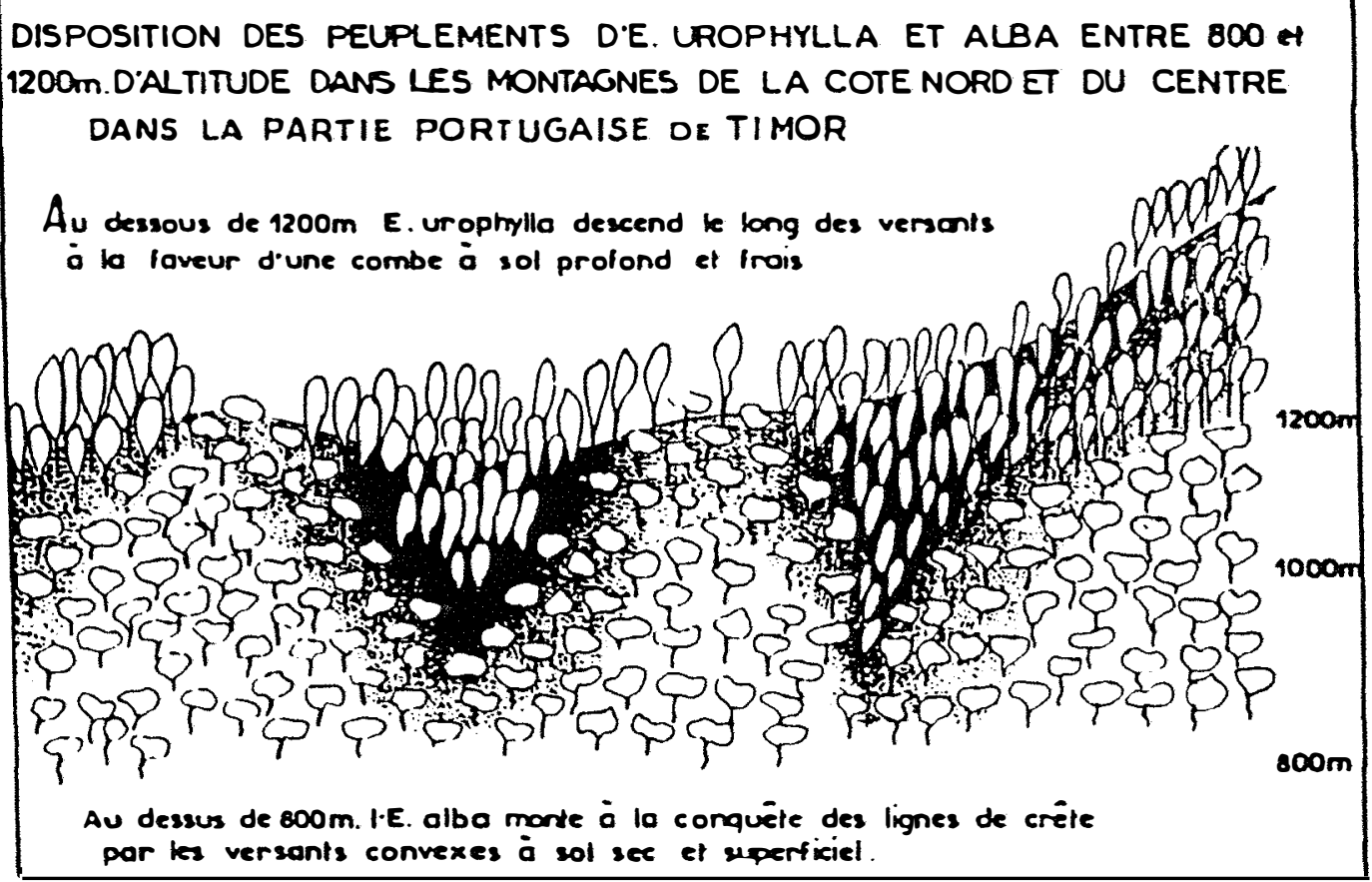

ALLURE DES FORMATIONS FORESTIERES DANS LA REGION DE RUGA (altitude $400 \mathrm{~m}$.) ILE DE FLORES

E. urophylla emergeont ou dessus du couvert de lo "RAIN FOREST"

Fulcie cloire d.E. urophyllo avec

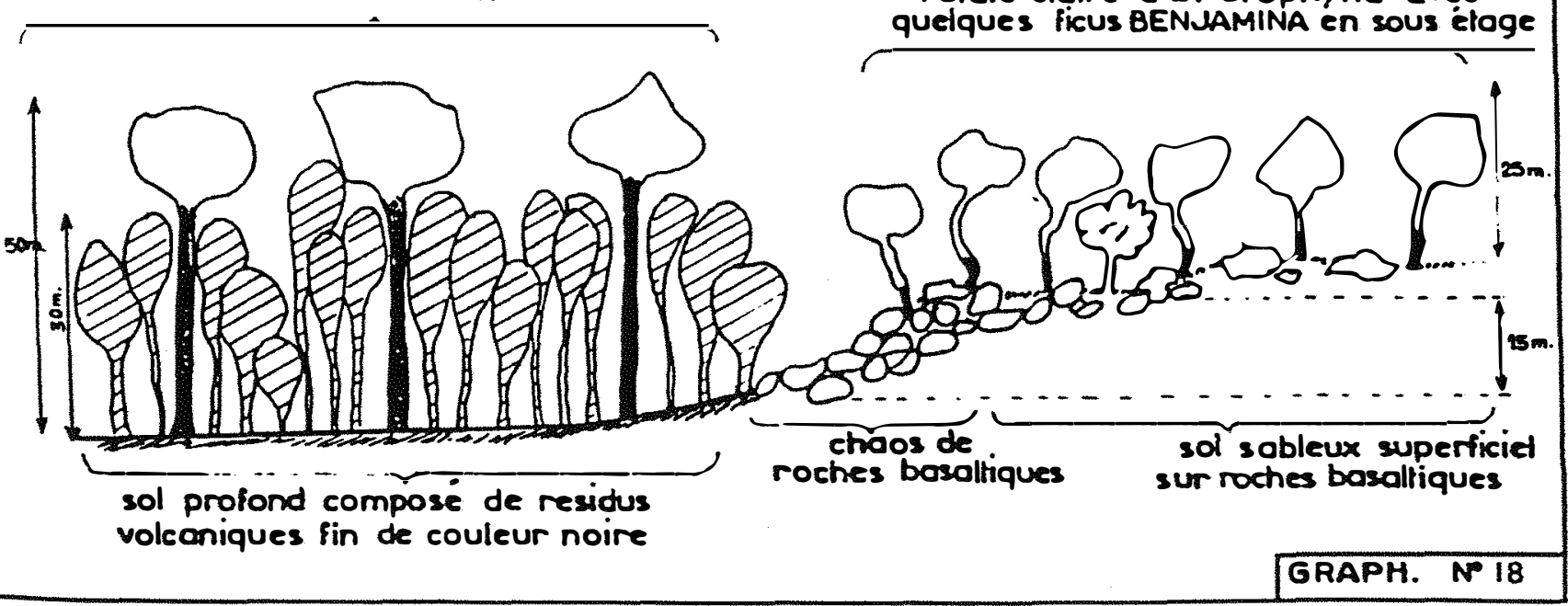

Figura 2 - Disposição das populaçōes naturais de $E$. urophylla e $E$. alba na região de ocorrência na Indonésia, em função da topografia e do solo. (Martin \& Cossalter,1975) 
Discussões sobre estes aspectos podem ser encontradas em Anderson (1968) que analisou a introgressão em populações herbáceas e arbóreas, salientando a ocorrência de processos de retrocruzamento entre os híbridos e as espécies pais, e ainda as possibilidades de sobrevivência desses novos genótipos e sua contribuição para a variabilidade natural de uma espécie.

Esse autor também salienta que a introgressão é frequente em áreas de contato de espécies aparentadas que estejam sob distúrbios naturais ( como climáticos, vulcânicos) ou antrópicos, onde os efeitos de clareiras e bordas modificam o equilibrio original e criam trechos de tensão ecológica onde os hibridos se tornam viáveis e expandem-se como populações em diversas frentes, com ou sem retrocruzamentos.

Podem gerar enxames híbridos, que sob certas condições produzem uma variação gradativa ou clinal, em relação à altitude ou latitude ; ou, em ambientes sob perturbação intensa e prolongada, produzem ecótonos ou alta divergência entre populações. Isto teria importante participação nos processos de especiação em longos periodos.

Wright (1976), discutindo a introgressão entre espécies e a produção de enxames híbridos, afirma ser possivel inclusive a formação de novas espécies ou subespécies por esses processos, após algumas dezenas de gerações.

Para eucaliptos, esse autor considera que isto seria comum em áreas sob intensos distúrbios naturais ou antrópicos, concordando com dados de Pryor que comprovou extensa colonização por híbridos em áreas do sudeste australiano (Nova Gales do Sul), em 10 a 20 anos após vastos incêndios florestais nos anos 1930 a 50.

Esta seria uma situação frequente nas ilhas Sonda ( Flores, Timor e as outras ilhas menores), onde os incêndios florestais por vulcanismo, os derrames de lava e deposição de cinzas e ainda vapores sulfúricos ocorrem sempre, há milênios.

Nestas áreas de transição entre a floresta pluvial e formações mais secas tipo savana de eucalipto dominada pelo E. alba, o E. urophylla desempenha um importante papel de espécie arbórea pioneira ou oportunista, colonizando as áreas abertas e formando florestas homogêneas do tipo aberta alta. Estas criam condições de subosque adequadas para a expansão da floresta tropical que volta a ocupar as encostas vulcânicas antes destruídas, e que contam com solos bastante férteis que 
se formam em poucas centenas de anos sobre cinzas ou derrames basálticos sob climas tropicais úmidos.

Um estudo aprofundado deste tema é feito por Adam (1994), que explica o papel dos eucaliptos como borda das florestas tropicais mistas na Austrália e Indonésia, discutindo os processos de regeneração e as respostas aos distúrbios em pequena e grande escala.

Este autor destaca, junto com os vulcões, as tempestades e ciclones tropicais, que rasgam vastas clareiras e tornam as florestas um grande mosaico com trechos em diversos estágios sucessionais simultâneos. Ele apresenta ainda os estudos climáticos desde 2 milhões de anos atrás no Quaternário, quando passaram a ocorrer intensas mudanças no clima, que alternaram nessa região ciclos de climas glaciais e desérticos, com contração e expansão da vegetação a partir de refúgios ou núcleos de vida localizados nas partes mais altas e protegidas do relevo.

Também houve sucessivas ligações e separações das atuais ilhas nos últimos 20.000 anos, devido à flutuação do nível do mar, o que colocava em contato e depois separava novamente por milênios as populações isoladas em ilhas, provocando fenômenos como introgressão, hibridação intra-especifica e adaptações divergentes.

Um exemplo desse processo de recolonização natural está sendo acompanhado há quase um século na Ilha Krakatoa, próxima a Flores, na Indonésia ( Mitchel Beazley/ IUCN, 1990). Uma violenta erupção destruiu completamente a ilha em 1888, e em poucas décadas o processo de sucessão natural já reconstituiu a floresta tropical em várias bordas do vulcão, que permanece ativo. Entre as espécies pioneiras ocorrem eucaliptos, apesar da floresta mais próxima estar em outra ilha separada por mais de $40 \mathrm{Km}$ de mar ( ver figura 3 ).

Esta situação é normal nas Ilhas Sonda, que nada mais são que os picos de uma cordilheira vulcânica submarina, com intensa atividade recente e ainda com erupções no presente. Em ilhas maiores como Flores, os distúrbios provocam clareiras que podem ser colonizadas com maior facilidade pelas extensas bordas formadas por eucaliptos, que são as espécies mais frequentes próximo às crateras dos vulcões e suas encostas ( ver figura no apêndice, com foto de população recém-destruida na llha Adonara ). 
As condições permitem uma rápida expansão das florestas abertas de eucalipto notadamente a descendência das árvores adjacentes e ainda a colonização por hibridos. que passam a dispor de um novo espaço com condições especificas a serem ocupadas

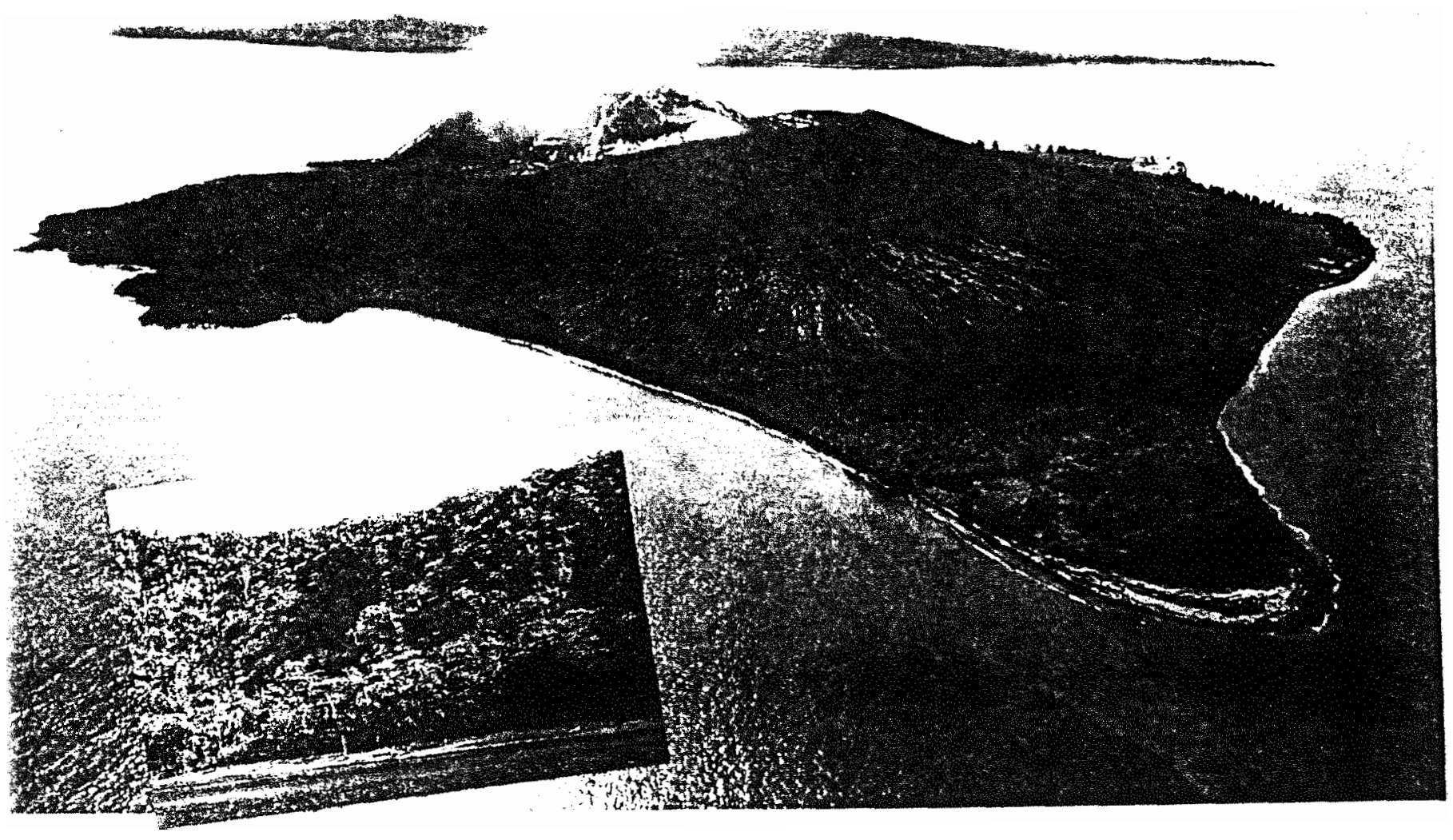

Figura 3 - Ilha Krakatoa na Indonésia destruida em 1888. onde em menos de 70 anos a sucessăo natural está regenerando a floresta em torno do vulcão que continua ativo. (Mitchel Beazley (IUCN. 1990). 
Uma outra situação existente é que as cadeias montanhosas nessas ilhas apresentam forte efeito orográfico sobre as chuvas, que resultam em uma face muito úmida voltada para o mar, e outra encosta muito mais seca do lado interno (Martin e Cossalter, 1975, ver figura 4 ). Não havendo barreiras reprodutivas entre essas regiões bastante próximas, deve ocorrer fluxo gênico entre populações que estão sob pressões de seleção para ambientes distintos, não só com gradiente altitudinal mas geográfico/ orográfico, o que é mais um fator gerador de variabilidade.

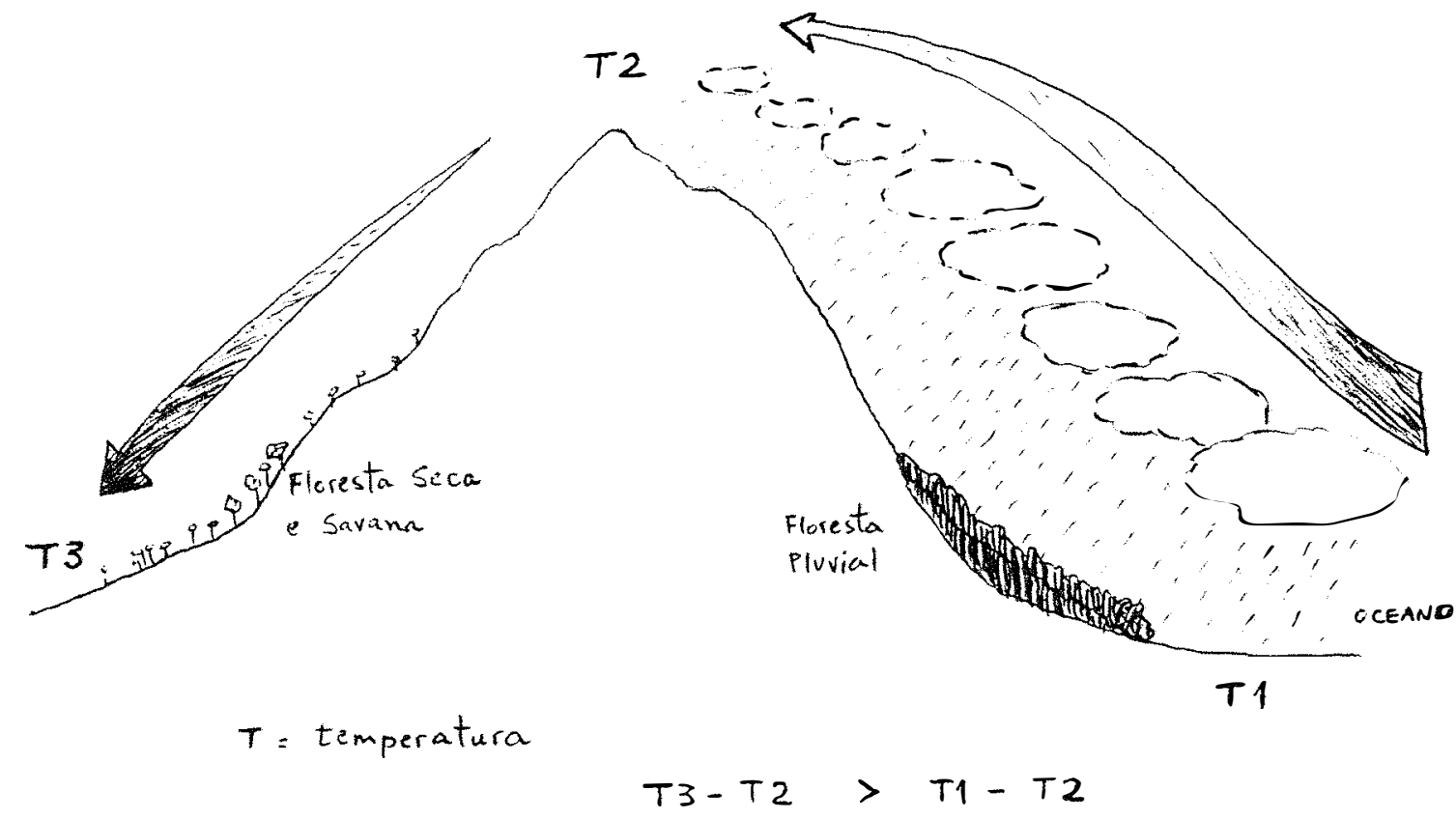

Figura 4 - Efeito orográfico em áreas montanhosas de ocorrência natural de E. urophylla nas ilhas Flores, Timor e outras do arquipélago de Sonda, Indonésia.

A situação de distúrbios e efeitos de borda/ destruição parcial/ formação de clareiras estreitas e longas passaram a ocorrer intensamente nos últimos 200 anos com a colonização e extração madeireira, inclusive reflorestamentos com E. urophylla no centro -oeste da llha Flores ( Martin e Cossalter, 1975), com base genética indeterminada, o que também pode interferir nas populações locais circundantes. 
Tudo indica que ocorreu um processo natural de especiação com introgressão em determinadas épocas, com retração e expansão de populações, o que resultou na atual variabilidade ampla de ideotipos e polimorfismo do complexo $E$. urophylla e as outras espécies relacionadas, recentemente descritas de acordo com Pryor, 1995 ( $E$. orophylla, E. wetarensis e ainda outra $E . s p$ ).

Esse processo certamente foi acelerado e perturbado pela ação humana e está sofrendo um forte desequilibrio pela crescente intensidade dos distúrbios dese 1960 (Mitchel Beazley/ IUCN , 1990 ). Está sendo inclusive interrompido em largas áreas pela destruição sistemática de populações inteiras da espécie para agricultura e pecuária, conforme ilustrado no apêndice (Martin e Cossalter, 1975). Informações via Internet em 1997, tanto de organizações conservacionistas como do próprio governo da Indonésia, evidenciam que este quadro se agravou, extinguindo vastas áreas florestais, seja pelo extrativismo ou por planos de "desenvolvimento".

\section{3 - Procedências de E. urophylla estudadas}

Há vasta descrição de centenas de procedências de $E$. urophylla, principalmente de Timor. Neste trabalho as informações foram concentradas sobre Flores e as Outras Ilhas, especialmente visando as procedências estudadas, com base principalmente no relatório de viagem de Vieira e Bucsan (1977), complementado com observações de Martin e Cossalter (1975 e 1976) e de Mitchel Beazley/ IUCN (1990). A descrição da situção de cada população permite subsidiar a discussão sobre os resultados obtidos, principalmente quanto à variabilidade natural.

- Ilha Flores

Serão descritas em detalhes somente as duas procedências de Flores de interesse para este trabalho: montes Egon e Lewotobi ( ver mapa 3). 


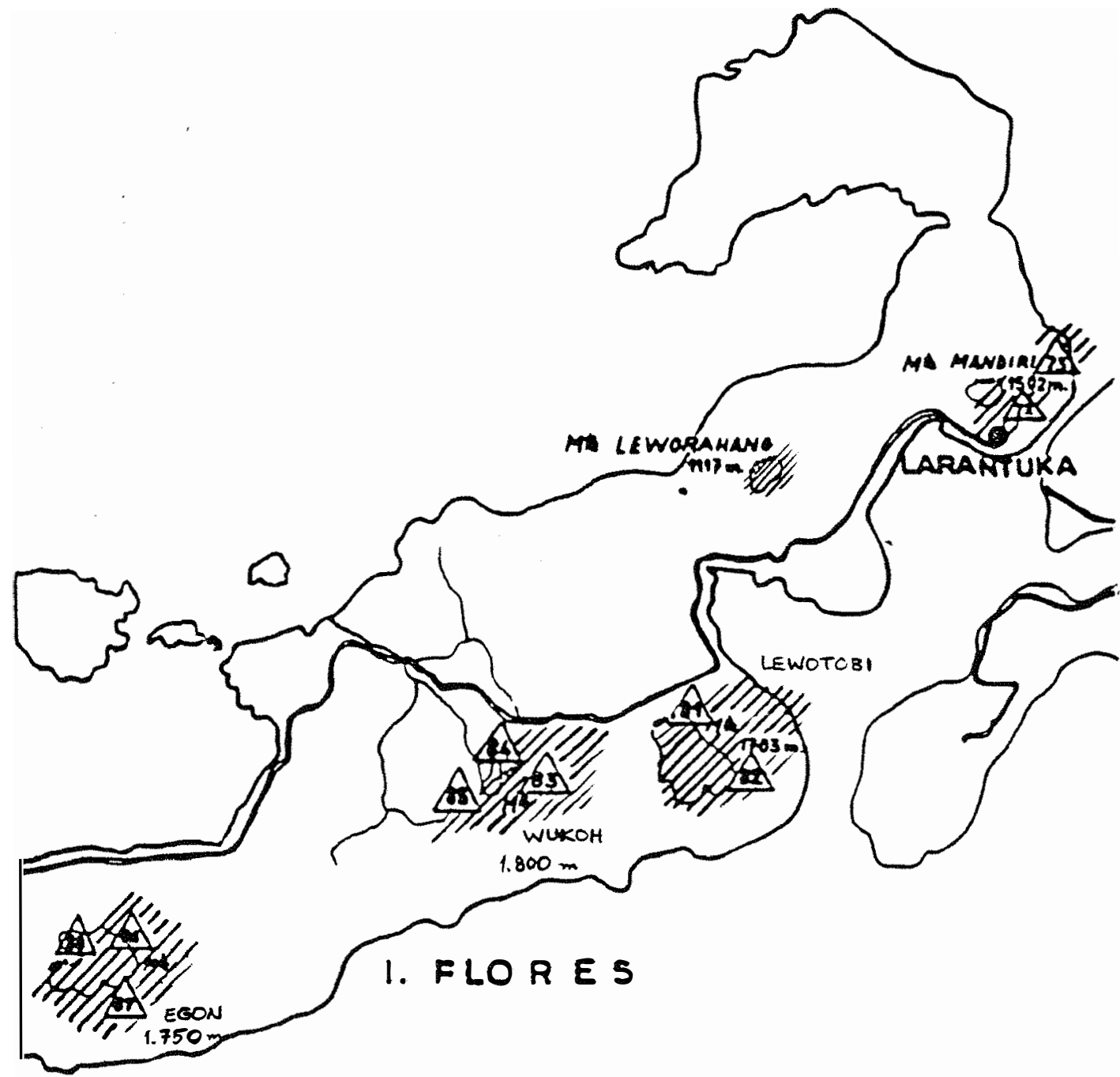

\section{Echel/e $\quad 5 \quad 10 \quad 15 \quad 20 \quad 25 \quad \mathrm{~km}$ \\ = emplacement appraximaif des peuplements d'Eucolyptus urophyllo}

Collecte provenonce d.E. urophyllo du provenance d.E. albo

Mapa 3 - Populações naturais de E. urophylla coletadas na llha Flores, Indonésia, como procedências ( Martin \& Cossalter, 1977). 
Mt.Egon: Este monte é um vulcão, com $1.600 \mathrm{~m}$ de altitude. Nesta área predomina o E.urophylla , com muita ocorrência de E.alba em pequenas manchas descontínuas numa altitude variando entre 200 e 400 metros. A partir de 400 metros pode-se encontrar E.urophylla, inicialmente disperso, ocorrendo associado com espécies nativas e depois mais densamente em povoamentos puros. A forma das árvores pode ser considerada boa, com as árvores apresentando bom desenvolvimento em altura, algumas com mais de 50 metros.

A regeneração natural é bastante intensa a partir de 650 metros, não havendo árvores muito desenvolvidas acima de 1.100 metros, onde o povoamento parece ser bem mais jovem. A frutificação acima de 900 metros de altitude praticamente inexiste.

Mt.Lewotobi: Também um vulcão, quase todo recoberto por E. urophylla, que ocorre desde os 450 até em torno de 1.100 metros de altitude. O povoamento nesta área é aparentemente mais jovem que o povoamento no Mt. Egon. A densidade da população é bem maior, favorecendo o crescimento de indivíduos com forma excelente. Aqui também aparece a desuniformidade quanto ao caráter casca rugosa, que cobre parte ou todo o tronco em variadas proporções.

Quanto à frutificação, a desuniformidade quanto ao tamanho e número de frutos por umbela á bastante acentuada, variando de 2 a 9 frutos por umbela. Como em Egon, o tamanho dos frutos tem também grande variação, encontrando-se frutos grandes, médios e pequenos. A característica mais uniforme nestas populações é a forma e tamanho das folhas, que pouco varia.

Nesta área há algumas manchas de E. urophylla associado com espécies nativas, em pequenas clareiras na floresta densa, às vezes não passando de 15 a 20 árvores em 3 - 5 ha. Aqui os indivíduos são bem mais desenvolvidos, com excelente forma do tronco e altura acima de 50 metros. O E. alba ocorre também em vários locais, na mesma área, também em pequenas manchas dispersas na mata nativa, às vezes junto com o E.urophylla, que é dominante nestas associações.

Os solos, como na maior parte da llha de Flores, são originários de erupções vulcânicas, algumas recentes, havendo grande quantidade de rocha basáltica na superfície. Foram coletadas nesta área uma procedência de $E$. alba a 400 metros de 
altitude e duas de E. urophylla, sendo uma de árvores com características desta espécie mas ocorrendo juntamente com E. alba a 470 metros de altitude, e outra procedênciai coletada a 700 metros de altitude.

- Outras Ilihas

Diveras outras ilhas, com coleta de menor número de árvores por procedência, foram agrupadas e plantadas como um teste de procedência em vários locais do país, incluindo a Estação Experimental de Ciências Florestais de Anhembi - SP (EECF), da Escola Superior de Agricultura "Luiz de Queiroz", ESALQ/ USP. São descritas aqui as Ilhas Adonara, Lomblem, Pantar e Alor, encontradas nessa sequência ao Leste da Ilha Flores, conforme o mapa 1 (geral, no texto) e em detalhes os mapas 2 e 3 (no apêndice).

- Ilha Adonara

Existem apenas dois locais onde ocorre o E. urophylla. A oeste da cidade de Waiwerang que é a capital da llha, há um pequeno povoamento, não chegando a 500 árvores. A altitude neste local está em torno de 500 metros. Na região próxima a Waiwerang, as árvores apresentam boa forma e bom crescimento. Os solos são de coloração cinza claro, originário de cinzas vulcânicas, com afloramentos rochosos frequentes.

O outro local onde se pode encontrar o E. urophylla em Adonara é no Mt. lleboleng ( ou Boleng), onde também ocorre o E. alba desde o nivel do mar até 450 $500 \mathrm{~m}$ de altitude. Nesta faixa encontra-se a área de contato, aparecendo alguns individuos supostamente hibridos. A partir de 550 metros observa-se o E. urophylla "puro".

Em Adonara, como em Flores, a variação das características de casca, frutos e forma é muito grande. A casca rugosa cobre o tronco em diversas proporções, desde 1 metro da base até todo o tronco. A forma das árvores de um modo geral é boa, sendo que as maiores apresentam sinais de quebra das extremidades das copas 
pelo vento. Os solos são bastante argilosos, escuros e férteis, provenientes de erupções vulcânicas, encontrando-se muitos afloramentos rochosos basálticos.

- Ilha Lomblen

Mt. lleape: A 700 metros de altitude surge o E. urophylla, ocorrendo até uma altitude de $1000 \mathrm{~m}$, em torno do vulcão (que atinge $1.450 \mathrm{~m}$ ). O E. alba aparece nesta região desde o nível do mar até uma altitude de 500 metros. Nesta área os ventos são muito fortes, com inúmeras árvores quebradas e com forma razoável.

Nota-se que a variabilidade da casca não é tão grande como nas procedências de Flores e Adonara. A casca é rugosa, com coloração marrom ferruginosa por todo o tronco, com exceção daquelas localizadas na borda inferior, ou seja,a uma altitude de 700 metros. Quanto ao tamanho e número dos frutos, a variabilidade é muito alta, havendo de pequenos a grandes, com 2 a 9 frutos por umbela.

Os solos também são originários de erupção vulcânica, sendo nesta área bastante argilosos, aparecendo com frequência os afloramentos rochosos basálticos.

A regeneração nesta região é bastante intensa, notando-se inúmeras mudas, que apresentam um grande desenvolvimento no caule ( ou lignotuber), que sofre influência do fogo colocado anualmente ao capinzal que recobre o solo nesta área.

Lelawerang: Apesar de não estar incluida no estudo, esta procedência, com altitude ao redor de $750 \mathrm{~m}$, merece ser citada por não estar localizada próximo a um vulcão. A forma das árvores não é satisfatória, pois quando não apresentam bifurcações ou tortuosidades, encontram-se injuriadas pelos ventos que em determinadas épocas do ano são fortes.

Não há $E$. alba nesta área, podendo-se encontrar entretanto, dentro da população de E. urophylla, alguns indivíduos com características típicas de E. alba. Todas as árvores apresentam em diversas proporções, partes do tronco cobertas por casca rugosa, como em Flores, havendo distinção nítida entre a casca rugosa e escura com a casca lisa e clara. Os solos possuem coloração cinza clara, bastante arenosos, não apresentando afloramentos rochosos. Os frutos são pequenos, médios e grandes, com número variável de 2 a 9 por umbela". 
- Ilha Pantar

Guman-Palmen: o E. urophylla localiza-se a cerca de $6 \mathrm{~km}$ da aldeia NuhaualaDesanule, numa altitude de 560 metros. As árvores apresentam características semelhantes às encontradas em Lomben e Flores. A casca rugosa, escura, de coloração ferruginosa, recobre os troncos e m diversas proporções.

Os frutos possuem grande variação em tamanho e número, com formato uniforme. As folhas são típicas, longas, sem grandes variações. Os solos são de coloração cinza claro arenosos, aparentemente com contribuição de cinza vulcânica.

O E. alba mais próximo desta procedência encontra-se $5 \mathrm{~km}$ ao norte, ocorrendo desde o nível do mar até uma altitude em torno de 450 metros.

- Ilha Alor

Mourou: Neste local, como em toda a llha de Alor, o E. urophylla ocorre em pequenas manchas, muitas vezes dentro de povoamentos de $E$. alba. Observa-se sempre que onde os solos são melhores aparece o $E$. urophylla, enquanto que o $E$. alba ocupa os solos mais pedregosos e aparentemente piores.

Raululang: O E. urophylla aparece numa encosta, com altitude variando de 370 a $400 \mathrm{~m}$, totalmente circundado por E. alba. Este povoamento compõe-se de árvores com forma e desenvolvimento muito bom.

Observa-se aqui a mesma desuniformidade quanto à casca, encontrada em Flores, Lomblen, Adonara e Pantar. A parte do tronco coberta com a casca rugosa escura é muito variável. O número de frutos é desuniforme, de 3 a 9 , assim como o tamanho, existindo frutos grandes, médios e pequenos numa mesma árvore. As folhas são mais uniformes, geralmente típicas, ou seja, longas, lanceoladas e com as extremidades finas e recurvadas.

Nos locais onde cresce o E. urophylla, os solos são aparentemente mais desenvolvidos, mais profundos e com boa estrutura. Já nos locais onde ocorre o $E$. alba, os solos são pouco desenvolvidos, mais rasos, com muitos afloramentos 
rochosos, oriundos de erupções vulcânicas de vários periodos. Todos os solos, tanto os melhores como os piores, têm coloração cinza escuro.

Woipui, Moimang e Waikui: Nestas três procedências, encontrou-se uma topografia fortemente acidentada, ocorrendo sempre o $E$. alba nas proximidades sem no entanto circundar o E. urophylla, como em Raululang. O E. urophylla aparece sempre nas partes mais altas, ocorrendo o $E$. alba nas partes mais baixas, até 500 metros de altitude. A desuniformidade referente à casca, tamanho e número de frutos também é notada aqui. Os solos são tipicamente originários de erupções vulcânicas, havendo grande quantidade de afloramentos rochosos (fotos no apêndice).

Estudando a variação altitudinal em E. urophylla, através de diferenças em sementes e mudas de 6 altitudes de Timor Leste e Pantar, Moura ( 1989 ) encontrou um decréscimo do tamanho das folhas e do comprimento dos entrenós do caule com o aumento da altitude, porém ocorrendo com isso um progressivo aumento da espessura das folhas. Concluiu que populações de baixa altitude estariam melhor adaptadas para crescimento nos trópicos, enquanto as de altitudes acima de $1.500 \mathrm{~m}$ só seriam indicadas para condições de climas amenos e úmidos, subtropicais ou de montanha.

Resultados de pesquisas comparando hibridos naturais de E. urophylla e as espécies parentais são raros na literatura. Esses estudos foram feitos principalmente na África tropical ocidental, em continuidade aos trabalhos de colete e testes de germoplasma realizados por pesquisadores franceses no Congo. Como exemplo, na tabela 1 estão resumidos os resultados de Chaperon (1976), para condições da África tropical, no atual Congo.

Tabela 1 - Dados dendrométricos aos 6 anos de idade no Congo, África. CIRAD.

\begin{tabular}{lccc}
\hline \multicolumn{1}{c}{ Parâmetros } & E. urophylla & $\begin{array}{c}\text { E. platyphylla } \\
\text { natural }\end{array}$ & $\begin{array}{c}\text { Híbrido artificial } \\
\text { E. alba x E. urophylla }\end{array}$ \\
Produtividade $\left(\mathrm{m}^{3} /\right.$ ha.ano $)$ & 20 & 5 & 21 \\
Adaptação & Média & Muito Boa & Ótima \\
Densidade Básica $\left(\mathrm{g} / \mathrm{cm}^{3}\right)$ & 0,54 & 0,7 & 0,75 \\
Forma & Média & Ruim & Ótima \\
Homogeneidade & Boa & Boa & Muito heterogêneo \\
\hline
\end{tabular}


Os estudos mais recentes publicados para a região do Congo, como os de Vigneron (1991) e Bouvet \& Vigneron ( 1997), conduzidos através do CIRAD em Pointe-Noire e Montpellier, tratam somente do uso de materiais clonados a partir de híbridos artificiais entre $E$. urophylla $X E$. grandis e E. tereticornis $X E$. grandis , derivados de seleção recorrente recíproca. Não são mais encontradas referências à continuidade dos estudos de seleção e estabilidade de ideotipos nas populações naturais e melhoradas do complexo E. urophylla / platyphylla. Aparentemente, segundo esses autores, por motivos econômicos e interesse de acelerar os resultados dos programas de melhoramento, as estratégias foram todas direcionadas para seleção precoce em materiais hibridados por polinização controlada, havendo grande preocupação com a interação clone $X$ ambiente.

\section{4 - Testes de procedência}

A melhor forma para obter rapidamente ganhos no melhoramento florestal é a escolha adequada da procedência das sementes. Como a adaptação é consequência da ação seletiva do ambiente, a escolha correta de uma procedência permitirá um ganho genético imediato para as características reguladas por gens que apresentam vantagem adaptativa para aquele local (Pryor, 1963).

Complementando comentário de Brasil (1983), o ganho genético obtido pela procedência pode ser maior para espécies com ampla distribuição na origem, sob condições edafoclimáticas e ecológicas variadas, e quando a população é selecionada por um longo período no mesmo ambiente, por várias gerações de recombinação.

Assim, Pryor (1963), citado por Brasil (1983), recomendou a instalação de testes de procedência em diversos locais, análogos ou não aos de ocorrência natural, para qualquer característica a ser melhorada. Também afirma que, sob cultivo, estes testes permitem conhecer o comportamento das diferentes procedências para cada situação tecnológica em particular.

Conforme exposto por Harris (1965), também citado por Brasil (1983), vários estudos de ecótipos geográficos mostraram que existem diferenças no crescimento e 
nas propriedades da madeira formada em localidades distintas e que a variação entre árvores, dentro de cada área, é grande. Os testes de procedência não revelam o mesmo grau de variação encontrado entre as populações naturais, mas podem indicar que certas espécies possuem raças geográficas com potencial produtivo distinto quando plantadas nas mesmas condições. Este autor afirmou que qualquer programa de melhoramento deve examinar todo o material genético ( procedências ) disponivel para seleção, visando explorar o seu maior potencial,que seria a hibridação intraespecifica e a recombinação. Um exemplo no Brasil é dado por Oliveira (1994).

As prioridades para avaliação de testes de procedência foram definidas por Burley et al. (1976), destacando parâmetros de crescimento, forma do tronco, arquitetura da copa, tipos de casca e, para maior idade, as características da madeira. Ressaltaram a importância da avaliação em idades jovens, para permitir estudos posteriores de correlação com a idade adulta.

Resultados de testes de procedência na região de origem, com os eucaliptos nativos em seu próprio ecossistema, foram apresentados por Burgess (1970), que encontrou variações significativas no crescimento em altura, para $E$. pilularis, $E$. grandis, E. maculata e E. cloeziana, espécies de interesse em Nova Gales do Sul, Austrália. Também Cracium ( 1978) apresenta um resumo dos resultados de dezenas de testes de introdução de 26 materiais entre espécies, procedências e híbridos no Território Norte da Austrália, obtendo superioridade para o híbrido de $E$. alba $X$ urophylla procedente do Congo, que adaptou-se melhor que qualquer material nativo.

\section{5 - Testes de procedência no Brasil}

No Brasil, centenas de testes de procedência e / ou progênie em eucaliptos, visando selecionar características de crescimento e de forma das árvores, foram feitos por diversos autores desde o início do século, como os de Andrade (1960).

Durante a grande expansão dos reflorestamentos com eucalipto no Brasil, nas décadas de 1970 e 80, houve uma grande preocupação com a introdução de novos genótipos e também com a reintrodução de muitos materiais que foram considerados 
não testados adequadamente. Dessa forma, vários trabalhos da época procuraram comparar os materiais selvagens com as raças locais já melhoradas, buscando substituí-los por novos genótipos com maior potencial produtivo e adaptativo.

Um exemplo dos trabalhos desse período seria Pásztor (1972), com E. pilularis, espécie de distribuição bem mais restrita do que $E$. urophylla, numa faixa de ambientes menos variados. O teste não demonstrou diferenças significativas entre as procedências australianas, mas uma superioridade de $30 \%$ em altura e em diâmetro dos novos materiais sobre os já melhorados no Brasil. Estes foram produzidos sob o esquema de matrizes isoladas ou "árvores brasões", que no passado geraram sérios problemas de endogamia por autofecundação para muitas espécies.

Esse processo de reintrodução passou por coletas de espécies preferenciais por algumas empresas, isoladamente, até culminar com um grande programa cooperativo de coleta de muitas espécies coordenado pela EMBRAPA em 1983. Este chamado "Projeto Eucalyptus" resultou na implantação de uma extensa rede nacional com dezenas de ensaios de testes combinados de procedência e progênie, cobrindo quase todas as regiões edafoclimáticas para reflorestamento no país. Detalhes atuais desse programa podem ser verificados em Higa ( 1993 ) e Higa et al. ( 1997 ) para várias espécies, encontrando diferenças altamente significativas entre procedências ; entretanto, ainda não apresentaram os resultados para $E$. urophylla.

A maioria dos trabalhos encontrados na literatura para $E$. urophylla refere-se a procedências da llha Timor, procurando comparar materiais de diferentes altitudes, como Páztor (1975), Fernandes (1986), Pires \& Parente (1986) e Gurgel Filho (1978). Não serão citados em detalhe por se tratar de materiais específicos de Timor, especialmente de maiores altitudes, considerados como bem diferentes das procedências em estudo ( Flores e Outras ilhas ). Mas uma conclusão comum a todos é que procedências de altitudes muito próximas, principalmente acima de $1.200 \mathrm{~m}$, não apresentaram diferenças significativas de crescimento. Alguns trabalhos apontaram ainda que em idades mais avançadas ocorre uma inversão no comportamento dessas procedências, com materiais inferiores aos 6 anos tornandose os melhores aos 16 anos ( Fernandes, 1986). 
Quanto ao potencial de adaptação, há trabalhos como o de Moura (1983), que testou procedências de ampla faixa de altitudes - de 500 a 2.700 m - em dois ambientes, de mata e cerrado. Concluiu que procedências de baixa e média altitudes, até $1.200 \mathrm{~m}$, foram superiores em crescimento nos dois ambientes, com vantagens evidentes no solo mais fértil de mata. As procedências de maior altitude cresceram menos sob clima/ solo de cerrado, devido à divergência entre o ambiente de origem, com solos vulcânicos férteis e clima úmido de montanha, e o ambiente seco/ pobre do cerrado do Brasil Central.

Pásztor ( 1990 ), estudando um teste de procedência de E. urophylla de diversas Ilhas ( Alor, Adonara, Pantar e Flores), concluiu que aos 7 anos de idade, para as populações testadas - de baixa e média altitudes, entre 300 e 1000 m - não houve diferenças significativas entre diâmetro e volume das árvores, somente entre as alturas. Isto confirmou concusões de outros autores citados, como Páztor ( 1975 ), Moura ( 1983) e Mendoza \& Danner ( 1983 ), de que populações originárias de uma faixa estreita de altitudes não apresentam diferenças significativas para parâmetros silviculturais. A tabela 2 resume os dados principais.

Tabela 2 : Teste de procedência de E. urophylla: Características silviculturais aos 7 anos. Luiz Antonio-SP, 1989, em Latossolo Roxo, espaçamento $3 \times 3$ m.

\begin{tabular}{|c|c|c|c|c|c|}
\hline PROCEDÉNCIA & $\begin{array}{c}\text { FALHAS } \\
\% \\
\end{array}$ & $\begin{array}{c}\text { ALTURA } \\
\mathrm{m}\end{array}$ & $\begin{array}{l}\text { DAP } \\
\mathrm{cm}\end{array}$ & $\begin{array}{c}\text { VOLUME } \\
\text { m3/ arV }\end{array}$ & $\begin{array}{c}\text { VOLUME } \\
\text { m3/ ha }\end{array}$ \\
\hline Flores - Lewotobi & 4,5 & 18,8 & 16,7 & 0,112 & 119,8 \\
\hline Flores - Egon & 3,2 & 19,1 & 18,3 & 0,163 & 175,3 \\
\hline Adonara & 3,7 & 17,6 & 16,8 & 0,117 & 125,1 \\
\hline Alor (3) & 3,7 & 17,5 & 17,4 & 0,129 & 138,3 \\
\hline Pantar (2) & 4.4 & 14,9 & 16,5 & 0,095 & 101,1 \\
\hline Significância & * a $5 \%$ & ** a $1 \%$ & ns & ns & ns \\
\hline CV \% & 20,8 & 9,5 & 8,3 & 28,3 & 30,6 \\
\hline
\end{tabular}

A equipe técnica da Cenibra Florestal (1985) apresentou os resultados de um amplo estudo com procedências de Flores, Outras Ilhas, e testemunhas comerciais, 
testadas no Vale do Rio Doce, em Minas Gerais. As principais conclusões aos 4 anos de idade foram:

a) a população de Outras Ilhas ( média de Alor, Adonara, Lomblem e Pantar ) cresceu mais em volume do que procedências de Flores e Timor;

b) as melhores procedências foram Woipui e Moimang, da Ilha Alor;

c) as testemunhas- raças locais de Camaquã, Casa Branca, Linhares e Salesópolis tiveram crescimento inferior às populações selvagens de Outras Ilhas;

d) as procedências de Flores apresentaram crescimento intermediário, sendo Egon a melhor de todas, acima das testemunhas brasileiras;

e) todas as procedências de Timor ( de altitudes acima de $1.100 \mathrm{~m}$ ) foram inferiores às testemunhas, e comprovaram outros resultados anteriores que recomendaram sua rejeição, após vários testes de introdução.

Os dados resumidos, de maior interesse para este estudo, estão na tabela 3.

Tabela 3 : Teste de procedência e progênie de E. urophylla, aos 4 anos, Belo Oriente-MG, clima tropical úmido, Latossolo VermelhoAmarelo, espaçamento 3 $X 2 \mathrm{~m}$. Procedências selvagens e raças locais brasileiras.

\begin{tabular}{ccccc}
\hline PROCEDENCIA & $\begin{array}{c}\text { ALTURA } \\
\mathrm{m}\end{array}$ & $\begin{array}{c}\text { DAP } \\
\mathrm{cm}\end{array}$ & $\begin{array}{c}\text { VOLUME } \\
\mathrm{m3} / \mathrm{an}\end{array}$ & $\begin{array}{c}\text { VOLUME } \\
\mathrm{m} 3 / \mathrm{ha}\end{array}$ \\
\hline Flores - Lewotobi & 13,8 & 11,2 & 0,061 & 101,7 \\
Flores - Egon & 14,6 & 11,3 & 0,070 & 117,0 \\
\hline Adonara (2) & 14,6 & 12,2 & 0,078 & 130,0 \\
Alor (4) & 14,1 & 12,2 & 0,078 & 130,1 \\
Pantar & 13,1 & 11,4 & 0,065 & 109,3 \\
\hline Timor - testemunha & 12,8 & 9,1 & 0,044 & 68,4 \\
\hline Significância & * a $5 \%$ & * a $5 \%$ & * a $5 \%$ & $*$ a $5 \%$ \\
\hline
\end{tabular}


Quatro procedências de E. urophylla da ilha Flores, entre as quais Lewotobi, foram estudadas por Pinto Jr. (1984), em 4 locais diferentes para uma ampla avaliação do potencial de adaptação da espécie, abrangendo desde regiões mais secas de cerrado e floresta semidecidua nos estados de Minas Gerais e São Paulo, até regiões de florestas tropicais - ombrófilas - úmidas do vale do Rio Doce e litoral do Espírito Santo. Foram avaliadas em 3 idades jovens, inferiores a 36 meses, explorando precocemente os resultados de um dos mais completos exemplos de rede experimental. Os dados desse autor que interessam para este estudo estão resumidos na tabela 34 .

Tabela 34 : E. urophylla, procedência Lewotobi, Ilha Flores, 3 anos de idade. 3 locais, 14 progênies, 3 blocos, parcelas lineares com 10 árvores.

\begin{tabular}{lcccccc}
\hline Local & Média & $\begin{array}{c}\text { Variância } \\
\text { Progênie }\end{array}$ & $\begin{array}{c}\text { Variância } \\
\text { Gen. Aditiva }\end{array}$ & $\begin{array}{c}\text { Variância } \\
\text { Fenotipica }\end{array}$ & $\begin{array}{c}\text { Variância } \\
\text { dentro }\end{array}$ & $\begin{array}{c}\text { Herdabilid } \\
\text { individual }\end{array}$ \\
\hline DAP & & & & & & \\
1- Aracruz & 11,74 & 0,3402 & 1,32 & 0,5606 & 6,6138 & $\mathbf{0 , 1 9}$ \\
2- Anhembi & $\mathbf{1 0 , 5 1}$ & $\mathbf{0 , 2 6 3 8}$ & $\mathbf{2 , 7 6}$ & $\mathbf{0 , 3 7 3 0}$ & $\mathbf{3 , 2 7 8 3}$ & 0,29 \\
3- B. Despacho & $\mathbf{8 , 2 8}$ & 0,1297 & 0,49 & 0,4328 & 5,7754 & $\mathbf{0 , 0 8}$ \\
\hline Altura & & & & & & \\
1- Aracruz & 15,28 & 0,0826 & 0,81 & 0,5435 & 7,7953 & $\mathbf{0 , 1 2}$ \\
2- Anhembi & $\mathbf{1 3 , 2 1}$ & $\mathbf{0 , 3 2 3 1}$ & $\mathbf{0 , 3 4}$ & $\mathbf{0 , 3 9 8 6}$ & $\mathbf{2 , 2 6 5 8}$ & $\mathbf{0 , 0 4}$ \\
3- B. Despacho & 9,61 & 0,4619 & 1,80 & 0,7681 & 3,8823 & 0,37 \\
\hline
\end{tabular}

Pode-se observar a grande amplitude de variação dos resultados e falta de um padrão, que para alguns parâmetros genéticos mostram maior influência ambiental em locais de maior estresse climático, refletindo, por exemplo, em menor herdabilidade, como é o caso do DAP e da altura na região de cerrado, também com maior variância fenotípica. 
Kikuti (1988), estudando progênies de E. grandis em comparação com materiais clonais, estimou os parâmetros genéticos que se mostraram semelhantes aos encontrados para outros eucaliptos. As progênies de meios-irmãos apresentaram maior variância dentro e menor variância entre progênies do que os materiais clonais, com os valores diminuindo com a idade. Os coeficientes de herdabilidade foram maiores no sentido amplo que no restrito, tanto a nivel individual como de médias de familias, apresentando diferentes padrões de variação com a idade para diversas características e para os materiais genéticos estudados. A seleção dentro de progênies com intensidade de seleção de $10 \%$ aumentou os ganhos genéticos estimados. Ressalta-se que mesmo esta espécie E. grandis, comumente considerada como " pura", na verdade apresenta um certo grau de hibridação desde a origem com E. saligna. E. botryoides e até $E$. tereticornis, conforme a procedência (ver revisão de Baez,1994, citando Pryor \& Johnson,1971; Passioura \& Ash, 1993; Brooker \& Kleinig, 1983; Burguess \& Bell, 1983). A hibridação pode interferir na estimativa dos parâmetros genéticos e pode alterar as premissas estabelecidas para populações em equilibrio, trazendo restrições na interpretação dos resultados, conforme já comentado.

Mori et alii (1996), em estudos para produção de hibridos interespecificos de $E$. urophylla. E. saligna e E. grandis, utilizaram caracterização isoenzimática de 15 progênies por espécie, analisando a variabilidade genética para as frequências alélicas e genotipicas, heterozigosidade dentro das espécies e o coeficiente de endogamia. Encontraram alto polimorfismo para essas espécies, com presença de contaminantes além da hibridação mesmo em cruzamentos controlados, devido principalmente à similaridade entre essas espécies.

Bienwagen et al.(1996) também estudaram populações hibridas de $E$. saligna de oito procedências australianas com 170 progênies, plantados em S.Paulo e originários da coleta realizada pela Embrapa/CNPF na década de 80 . Concluem que sob condições de estresse ambiental, muitos hibridos apresentam alto potencial adaptativo e crescimento muito superior às espécies pais. Porém, os autores sugerem novos estudos sobre a estabilidade fenotípica e levantam dúvidas sobre os padrões 
fenológicos desses híbridos dentro da população, considerando sua espontaneidade ainda em primeira geração.

Resultados de Freitas et al. (1997), obtidos aos 5 anos de idade com progênies de E. urophylla originárias de Rio Claro - SP e de Três Lagoas - MS, e plantadas em Selvíria - MT, revelaram superioridade, estatiscamente significativa, para o material introduzido frente ao selecionado localmente, apesar de não detalhar as procedências originais. Foram estimados parâmetros genéticos para altura e DAP, apresentando resultados semelhantes aos de Mori et al. (1988) em outras 4 localidades.

Scanavacca et al.(1993) também apresentam resultados de E. urophylla para um amplo teste com 23 procedências indonesianas e 200 progênies em Jari - PA. A avaliação do volume 5 anos de idade revelou diferenças significativas para todos os materiais, com superioridade para as procedências de Flores (maior variabilidade genética e maior diversidade de ideotipos), com as Outras Ilhas em classificação intermediária e Timor demonstrando inadaptação às condições amazônicas, como seria esperado para genótipos oriundos de maiores altitudes e clima mais ameno.

2. 6 - Variação natural e ideotipos em eucaliptos

Cangiani ( 1992), ao avaliar a seleção em mudas de hibrido de $E$. grandis $X E$. camaldulensis e E. saligna/ botryoides/ tereticomis, testou metodologias para identificar e separar ideotipos em viveiro. Concluiu que muitos tipos apresentaram alta heterogeneidade foliar, desenvolvimento inferior e dificuldades de separação para correlação silvicultural futura, pois houve alteração fenotipica da classificação entre 3 e 8 meses; entretanto, alguns padrões definidos como hibridos aos 3 meses se mantiveram diferenciados, conservando suas caracteristicas, o que já foi observado no campo por outros autores, principalmente para hibridos com espécies de arquitetura da copa tipica ou folhas (cor, cheiro, pilosidade, forma) muito especificas para uma espécie, como ocorre com E. camaldulensis, E. pellita e E. citriodora, por exemplo. 
Baez (1994), em estudo detalhado de população hibrida de E. saligna de Itatinga-SP, avaliou 48 árvores matrizes e as sementes e mudas de suas progênies, usando 7 caracteres morfológicos em viveiro, além da variação na produçâo de sementes, aplicando quatro métodos de agrupamento e gerando dendrogramas. Concluiu que há separação em dois grupos distintos dentre um gradiente hibrido, separando-os nos tipos saligna/ hibrido e botryoides, com este último apresentando grande dispersão com ampla variação das caracteristicas morfológicas. Porém, ressalta que muitas variáveis tiveram que ser descartadas (descarte por redundância) e a técnica empregada se revelou pouco promissória, nas palavras da autora, para ordenar as matrizes apenas pelas características de folhas e frutos. Constatou ainda que a técnica de componentes principais adotada foi pobre como metodologia para ordenar as progênies, mostrando estrutura de agrupamento débil em muitos casos, não concordando com o agrupamento fenotípico das matrizes. Como conclusão geral, novamente ficou comprovada a grande dificuldade de estudar populações com alto grau de hibridação e retrocruzamentos, ainda não estabilizada por sucessivas gerações de recombinação.

López (1992) estudando clones selecionados em E. urophylla, pelo método da análise multivariada, deparou-se com a imensa variabilidade existente, que dificultou grandemente estabelecer padrões hierárquicos de semelhança entre os materiais, outra vez comprovando a incapacidade de evidenciar estatisticamente, com os métodos atuais, a diferenciação encontrada nessas populações hibridadas por polinização livre.

Bierwagen et al. (1997) estudaram a seleção e caracterização de híbridos naturais em populações de $E$. saligna sobre condições de estresse nutricional em solos muito arenosos. Estabeleceram 3 padrões para folhas e arquitetura, encontrando entre as árvores superiores, $68 \%$ de hibridos que apresentaram grande crescimento em volume com mais de $350 \%$ de acréscimo sobre a média da população. Afirmam que o vigor hibrido desses genótipos raros requer estudos sobre sua estabilidade fenotipica para crescimento, qualidade da madeira e quanto à fenologia e exigências nutricionais. 
Luz e Ferreira (1987), avaliando a seleção de híbridos espontâneos ( ocorrência ex situ, ou seja, fora da origem) de eucaliptos para diversos materiais, especialmente dos subgêneros Symphyomirtus e Corymbia, para cruzamentos entre espécies de floresta aberta e fechada, estabeleceram os principais parâmetros de fácil identificação para mudas. Constataram a ampla dispersão e a grande variabilidade por interação entre as diversas características morfológicas, especialmente forma e cor de folhas e a arquitetura das mudas. Estes materiais, plantados separadamente por tipos, na maioria dos casos não comprovaram diferencial dendrométrico nem vantagens silviculturais, indicando ausência de correlação entre forma e adaptação para muitas categorias dos tipos arbitrados em viveiro. A coclusão final foi que para alguns extremos há diferenças de crescimento, mas a maior parte dos ideotipos representa um gradiente difuso e casual difícil de correlacionar e interpretar, sendo provavelmente uma variação natural sem consequências adaptativas.

Luz et al. (1996) em trabalho com as mesmas populações de E. urophylla deste estudo, encontraram diferenças significativas para todos os parâmetros dentro das populações, em três idades e dois espaçamentos, antes e após um desbaste seletivo. A separação por ideotipos revelou superioridade no crescimento das árvores de casca lisa sobre os outros tipos, e houve tendência da seleção dirigida para esse ideotipo aumentar a sua frequência na população após uma geração de seleção. Sugerem ainda que, após duas gerações de recombinação, deverá haver maior eficiência do melhoramento e maiores ganhos genéticos.

Gouvêa et al. (1997) estudaram em Rincão - SP, duas populações de $E$. urophylla de testes de procedência e progênie ( Altinópolis-SP, de Egon-Flores, e Flores de Três Lagoas-MS), avaliando a produtividade e qualidade da madeira de árvores superiores com diferentes padrões de casca rugosa nas melhores progênies. Os padrões foram divididos em 3 proporções de casca rugosa persistente ( arbitraram em classes: $0-25 \%, 25-75 \%$ e $75-100 \%$ da altura da árvore), sem usar o conceito de ideotipo. Concluiram, de forma preliminar, que o padrâo de casca persistente de 25$75 \%$ apresentou superioridade para todas as características estudadas, indicando haver ganhos em produtividade para seleção dirigida a este tipo de casca. Mas consideraram que, do ponto de vista prático, a utilização dos padrões fenotípicos de 
casca não possibilitaram uma efetiva seleção das características estudadas. $\mathrm{Na}$ verdade, dve-se discordar desta divisão muito simples e arbitrária, resumindo casca à sua altura de ocorrência em porcentagem, pode estar misturando diferentes ideotipos com comportamento distinto, além de não haver estudos genéticos associados, o que prejudica qualquer tipo de seleção, pois é provável que não haja nenhuma correlação nas próximas gerações.

Ferreira ( 1990 ), discutindo os rumos das pesquisas com populações de eucalipto e fazendo uma análise crítica da atual silvicultura clonal, debate o uso intensivo de materiais e destaca a importância de entender e aproveitar as variações naturais já existentes, aplicando os conhecimentos disponiveis sobre a origem e o histórico de seleção dessas populações. Segundo o autor, ainda há muita variabilidade e um alto potencial de adaptação naturalmente já alcançado, que estariam disponiveis para a continuidade dos programas de melhoramento do setor florestal brasileiro e poderiam ser melhor aproveitados. Nesse contexto ${ }^{2}$, a identificação, separação e o aproveitamento criterioso dos ideotipos seriam ferramentas de grande valor para trabalhar adequadamente essas populações.

Ferreira \& Santos (1994 e 1997), em extensa revisão e análise crítica do melhoramento florestal no Brasil, afirmam que, com a priorização da silvicultura intensiva clonal na década de 90 , as pesquisas básicas em melhoramento genético de populações são paralisadas ou prejudicadas. A prioridade passa a ser busca da "árvore superior", como unidade de propagação clonal, numa visão imediatista que rapidamente seleciona e multiplica clones e códigos/ números (!) nos jardins clonais, testes e plantios clonais extensivos, especialmente com híbridos "E. urograndis" e afins. As pesquisas com espécies, procedências/ progênies, pomares de sementes, polinização controlada, enfim, na visão de longo prazo do melhoramento de populações, são desativadas ou desaceleradas, perdendo continuidade e a massa crítica de seus pesquisadores.

2 Ferreira, M. ESALQ/USP, Comunicação pessoal. 1997. 


\section{7 - Métodos de seleção para eucalipto}

$\mathrm{Na}$ área de Melhoramento Genético Florestal, os trabalhos normalmente têm sido conduzidos com populações naturais recém introduzidas ou em fase de domesticação e adaptação das espécies, na primeira ou segunda geração de seleção. A variabilidade natural ainda é bastante alta, podendo ser explorada por muitas gerações. Há ainda a presença marcante de hibridações. Higa et al. (1992) comentam que os programas de melhoramento genético de Eucalyptus no Brasil envolvem ciclos sucessivos (gerações) em que se aplica métodos a diversos tipos de populações, contando inclusive com recentes reintroduções nos anos 80 e 90 , visando o aumento da produtividade e da qualidade da madeira.

Com base na literatura consultada, procurou-se reunir e resumir os principais conceitos de melhoramento florestal que formam a base deste estudo, permitindo uma interpretação correta das tabelas de resultados. Os principais autores de onde foram extraídos os conceitos a seguir são: Allard (1964), Ferreira (1976), Namkoong (1979 e 1988), Zobel e Talbert (1984), Venkovsky e Barriga (1992), Eldrige et al. (1993), Rezende e Bertolucci (1993). As citações não foram feitas por parágrafos pois se tornariam muito repetitivas, sendo muitas frases compostas por mais de um autor.

\section{Definição e aplicação dos parâmetros genéticos}

Os propósitos da estimativas dos parâmetros genéticos são o conhecimento de informações sobre a natureza da ação dos genes envolvidos na herança dos caracteres sob investigação e dar subsídios para a avaliação de planos de melhoramento da população, assim como para orientação sobre o esquema mais adequado de seleção a ser adotado.

A matéria prima para a seleção é a variação genética, que é a parte herdável da variabilidade fenotípica, portanto, a que se transmite de uma geração para outra.

Para uma dada característica, ao componente genético da variação fenotípica denominamos de variação genética, que pode ser decomposta em variância genética 
aditiva e variância genética não aditiva (dominante e epistática). É de maior interesse para o melhoramento sexuado a variância genética aditiva, pois é a transmitida à sua descendência ( Allard, 1971).

O diferencial de seleção [ d.s. $=\mu s-\mu_{0}$ ] é a medida de intensidade na seleção, ou a diferença entre a média da população selecionada $\left(\mu_{\mathrm{S}}\right)$ e a média da população original $\left(\mu_{0}\right)$.

A herdabilidade ou coeficiente de herdabilidade $\left[\mathrm{h}^{2}=\right.$ variância genética / variância fenotípica ] exprime a proporção de variância fenotípica que é de natureza genética.

Este parâmetro não é fixo, variando com o material genético e com o ambiente em questão, portanto uma mesma procedência em dois ambientes diferentes pode ter herdabilidades diferentes para o mesmo caráter. Pode ser expresso de dois modos:

- No sentido amplo, quando considera a variância genética total

- No sentido restrito, quando considera apenas a variância genética aditiva.

Na maioria dos casos do melhoramento florestal a herdabilidade de interesse é a no sentido restrito: $h^{2} r=$ variância genética aditiva / variância fenotípica.

Entre os parâmetros genéticos, valores de estimativas de herdabilidade são importantes por estimarem o grau de confiabilidade da expressão fenotípica como um indicador do valor genético de certa característica.

A eficiência de determinado método de melhoramento, como a seleção massal, depende em parte do valor da herdabilidade do caráter a ser melhorado, além de sua correlação com outros caracteres, da intensidade com que a seleção é exercida e da variabilidade genética da população (Allard, 1971). Assim, a herdabilidade :

a) expressa o grau de correspondência entre o valor fenotípico e o valor genético de um caráter; 
b) é a medida relativa do grau com que um caráter é influenciado pela hereditariedade quando comparado com o ambiente;

c) é a expressão matemática que representa as relativas contribuições do genótipo e do ambiente sobre o fenótipo.

Um alto valor de herdabilidade indica que o fenótipo reflete seu genótipo e que as mudanças no ambiente influem pouco no fenótipo, ou seja, o controle genético é alto e o método de seleção aplicado seria mais eficiente.

A estimativa do erro associado aos componentes de variância, é bastante importante para a visualização do grau de confiança da estimativa do parâmetro, entretanto não tem sido calculada para a maioria dos casos em espécies florestais.

O erro associado à variância genética obtido da análise de variância é inversamente proporcional aos graus de liberdade para progênies e resíduo, e ao número de repetições e de plantas por parcela. Isto significa que quanto mais repetições ( blocos ) e quanto maior for a parcela experimental, menor poderá ser o erro associado à herdabilidade.

O ganho genético [ $\Delta G=d s^{*} h^{2} r / \mu \circ$ ] é o parâmetro que exprime o avanço da geração seguinte selecionada em relação à original.

Escolha dos métodos de seleção na população

Após a definição de uma população base constituida por uma espécie e procedência adequadas, opta-se pelo método de seleção entre alternativas como as estudadas por Bueno Filho (1992) ou comparadas por Rezende \& Bertolucci (1993).

Há basicamente duas opções para seleção intra populacional :

Seleção massal e Seleção individual ou sequencial.

\section{Seleção massal}

Na seleção massal, as árvores são escolhidas em função de uma avaliação fenotípica, e as respectivas sementes são misturadas sem teste de progênie, para 
reproduzir a próxima geração. É aplicada em ACS (Área de coleta de sementes) e APS (Área de produção de sementes). Conforme Ramalho (1993) preconiza, a utilização de ciclos sucessivos de seleção (seleção recorrente) é o processo mais recomendado, pois a maioria dos caracteres de importância econômica é controlada por muitos genes, e nas primeiras gerações é mais desejável beneficiar-se da recombinação populacional.

Um exemplo de sucesso com seleção massal é dado por Xavier et al. (1997), que para $E$. grandis na região centrol nordeste do estado de S. Paulo, comprovou experimentalmente ganhos de até $41 \%$ em volume e $10 \%$ em altura entre a $1^{a}$ e a $2^{a}$ geração selecionadas ( F1 e F2). E quanto ao efeito da estratégia de multipopulações avaliada, os autores concluem que as populações regionalizadas indicam um melhor desempenho em cada uma das regiões de melhoramento.

Bienwagen et al (1997) também optaram pela seleção massal em uma população de E. urophylla de Outras Ilhas ( Pantar, Alor e Lomblem) plantada em Anhembi-SP. Este método proporcionou maiores ganhos genéticos com a desejável manutenção da base genética aos 4 anos de idade, o que é muito importante para que haja recombinação.

\section{Seleção individual ou sequencial}

Nos programas de melhoramento genético do eucalipto no Brasil, geralmente é adotado o método da seleção sequencial entre e dentro de familias de meios irmãos, baseado em algum caráter de crescimento. Neste tipo de seleção, a individualidade das árvores é mantida no decorrer do programa, implicando naturalmente na realização de testes de progênie das árvores selecionadas .

Pode-se também, paralelamente, propagar vegetativamente as árvores selecionadas para a formação de um PSC (Pomar de Sementes Clonal) de $1^{a}$ geração, e avaliá-las através de testes de progênie, que submetidos a seleção entre e dentro de famílias será transformado em PSM (Pomar de Sementes por Mudas), conforme exposto por Campinhos \& Ikemori ( 1988). 
Seleção combinada

A seleção baseada em índice tem sido, recentemente, utilizada no melhoramento florestal, proporcionando ganhos maiores, usualmente, quando comparados aos obtidos por outros métodos, conforme discutido por Rezende, Oliveira \& Higa (1990).

O uso da seleção combinada através de um indice de seleção que reúna informações do próprio individuo e da média da progênie a que pertença é uma técnica primeiramente desenvolvida para o melhoramento animal e posteriormente adaptada para o melhoramento florestal. É um refinamento da seleção sequencial, mais adequado a programas operacionais, por explorar mais intensamente a variância genética aditiva.

Conforme resultados de Rezende \& Bertolucci (1993), para E. urophylla em Aracruz-ES, a seleção combinada aplicada aos 4 anos de idade, por permitir uma discriminação eficiente do valor genético dos materiais ao nivel de individuos, é um método excelente de seleção, sendo um importante avanço para programas de melhoramento genético de eucalipto.

Testes de progênie de polinização livre

Este método de testar e obter descendência de progênies de meio-irmãos, e de obter as estimativas de parâmetros genéticos destas familias, é o que mais vem sendo utilizado em espécies florestais no Brasil. Isso se justifica pela sua facilidade de instalação em relação aos testes de progênie de irmãos completos (ou germanos) que exigem polinização controlada.

Os testes de progênie de polinização livre, onde foi realizada seleção sequencial, têm apresentado boas estimativas de progresso para dados experimentais, desde que mantidas as bases genéticas adequadas para as populações, realizando um "manejo dos genes" equilibrado (Namkoong, 1988).

No meio florestal, geralmente os testes de progênies, que prioritariamente têm o objetivo de testar árvores mães para um programa de "Produção de Sementes", são aproveitados para obter as estimativas de parâmetros genéticos da população ( ver 
Kikuti, 1988 ; Kageyama \& Kikuti , 1988 ; Luz et al. 1996 ; Bienwagen et al. 1996, entre outros).

Também observa-se, em muitos testes, que os individuos foram selecionados na população, não sendo uma amostra tomada ao acaso, condição essencial para que as estimativas dos parâmetros sejam generalizadas para essa população.

Sobre este inconveniente, Toda (1972), citado por Kageyama (1983) e por Torggler (1987), mostra que a seleção de indivíduos na população reduzirá os valores da variância total e variância entre familias na mesma proporção, mantendo mais ou menos constante a estimativa da herdabilidade, alertando que as estimativas poderão estar sendo mais influenciadas pela variabilidade ambiental que por fatores genéticos.

A maioria dos experimentos com progênies de polinização aberta adota delineamentos com um número relativamente pequeno de familias, normalmente bem abaixo de 50, e com árvores não tomadas ao acaso na população.

Apesar das restrições, o teste de progênies de polinização aberta é o método mais barato e a metodologia mais utilizada em espécies florestais, permitindo estimar os parâmetros genéticos das populações de interesse.

Porém, para estimação ampla e sem restrições dos componentes da variância genética, há uma condição essencial: tanto os individuos aparentados que constituem o material experiemental, como os da população base, não devem ser endo-cruzados. Nesse sentido, Namkoong (1966), citado em Kageyama (1983) sobre os problemas de endogamia e sua influência nos testes de progênies, levanta restrições sobre a estimativa de variâncias genéticas aditivas da população através da utilização de sementes de polinização livre. Se a endogamia prevalecer, o teste de progênie de polinização aberta inflaria as estimativas da variância genética.

Segundo Eldridge (1977) também citado em Kageyama (1983), existem evidências de que tanto autofecundação como cruzamentos ocorrem nos eucaliptos, com predominância da alogamia.

Pryor (1976) define que que o sistema genético de Eucalyptus é um sistema clássico de recombinação aberta, com taxas de cruzamento altas devido principalmente à protandria. E ainda, há contribuição para esse processo por uma 
seleção natural contra os individuos originados por autofecundação, desde a fase de muda até a árvore adulta (Griffin et al., 1988).

Rezende \& Resende (1997) comentam que a estimação dos ganhos genéticos com seleção intrapopulacional baseia-se na recombinação equitativa dos individuos selecionados, assumindo que todos eles contribuem com a mesma proporção de gametas para cada geração melhorada. Entretanto, para arbóreas perenes, de fato ocorre uma contribuição desigual dos parentais, pois o comportamento fenológico é sazonal e variado para cada individuo, e a cada ano é diferenciado na intensidade da floração e consequente polinização. Com isso, os autores concluem que, manejando seletivamente esse aspecto, ao preferir os cruzamentos mais potenciais entre individuos com maiores valores genéticos, a eficiência da seleção poderá ser aumentada, resultando em 5 a 10\% a mais de ganho genético e de tamanho efetivo populacional.

Ferreira (1986) esclarece que a formação de raças locais está baseada em que a superioridade fenotipica das árvores é ligada a genótipos superiores, não sendo de causa acidental por favorecimento ambiental, especialmente quando se trata de uma população em melhoramento. Os resultados de Esbrisse et al. (1997), confirmaram essa hipótese, ao estudarem a estabilidade e adaptabilidade genotipica de 55 progênies de E. urophylla de Outras Ilhas (Alor, Pantar e Wetar) em 5 ambientes em Jari - PA. Encontraram que em torno de $20 \%$ dos genótipos da população (familias) mostraram boa estabilidade geral e alta previsibilidade, com a interação entre esses genótipos em competição refletindo em maior adaptabilidade e consequente estabilidade populacional.

Matheson (1988) debate os problemas causados na experimentação quando os testes de genótipos se tornam grandes e cobrem áreas amplas, que sempre apresentam microvariações de solo. Afirma que nos testes de progênie deve-se reduzir o número de familias e diminuir o número de repetições, até um ponto de equilibrio em que não se confunda a interação genótipo $X$ ambiente com heterogeneidade dos micrositios dentro da área experimental. Recomenda que a divisão dos genótipos em grupos é uma forma de contornar esse problema. Nesse contexto, desde que viável para a espécie estudada, o uso dos ideotipos seria 
desejável para estratificar os materiais, especialmente no caso de testes clonais usando híbridos, o que reduziria a competição desigual e o efeito da competição intraespecifica na seleção de clones superiores, conforme Mori (1987) e Mori \& Kageyama (1988). Segundo estes autores, dos 4 aos 6 anos de idade, a influência de um genótipo superior sobre outros se manifesta de 2 a $9 \mathrm{~m}$ de distância entre árvores, influindo nos coeficientes de variação fenotípica que refletem a competição. E quanto maior a herdabilidade para uma caracteristica, menor é o efeito da competição na mesma, sendo a altura a menos influenciada pelo ambiente. 


\title{
3 - MATERIAL E MÉTODOS
}

\author{
3. 1 - MATERIAL
}

\section{1. 1. Espécie / Procedências}

A espécie estudada foi o Eucalyptus urophylla S.T.Blake, com 3 materiais genéticos que envolvem três populações distintas.

Duas são materiais de populações selvagens, $F_{0}$, procedências de origem indonesiana Monte Lewotobi e Monte Egon, ambas da llha Flores, recebidas da EMBRAPA através da CSIRO, que as obteve em coletas na Indonésia em 1987-88.

A outra população é uma $F_{1}$, considerada como uma raça local, adaptada à região central do estado de $S$. Paulo, resultante da recombinação das procedências das ilhas Alor, Pantar, Adonara e Lomblem. Foram obtidas através de colheita da Cia. Vale do Rio Doce ( Vieira e Bucsan, 1977) na origem, sendo plantadas pela ESALQ em Anhembi.

Quanto aos dados geográficos, a latitude amostrada na origem foi próxima ao paralelo $8^{\circ}$ Sul. A variação mais importante é na longitude, que abrangeu de 122 a $124^{\circ} 30^{\prime} \mathrm{E}$. Em relação à altitude, variou de 370 a $700 \mathrm{~m}$ em regiões montanhosas, ou seja, em torno de $300 \mathrm{~m}$ de diferença.

A vegetação natural nos locais de coleta variou de floresta tropical pluvial (rainforest) a subosque esparso arbustivo sob população pura de E. urophylla. Várias procedências coexistiam com E. alba. 
O número de árvores matrizes colhidas variou de 3 a 24 , sendo que após agrupadas, obteve-se 34 árvores para a llha Flores e 24 para Outras Ilhas. Os detalhes sobre as procedências originais estão na tabela 5.

Tabela 5 : Descrição das procedências originais de E. urophylla, Flores e Outras llhas da Indonésia, usadas nos 2 experimentos, com base nos cadastros da EMBRAPA, do IPEF e da CSIRO :

\begin{tabular}{|c|c|c|c|c|c|c|c|}
\hline $\begin{array}{l}\text { EXP / } \\
\text { TRAT. }\end{array}$ & LOTE & $\begin{array}{l}\text { LOCAL } \\
\text { ORIGEM }\end{array}$ & $\begin{array}{c}\text { LATIT }{ }^{\circ} \\
S\end{array}$ & $\begin{array}{l}\text { LONGIT. } \\
{ }^{\circ} \mathrm{E}\end{array}$ & $\begin{array}{c}\text { ALTIT. } \\
m\end{array}$ & $\begin{array}{l}\text { Espécie } \\
\text { associada }\end{array}$ & $\begin{array}{l}\mathrm{N}^{\circ} \text { de } \\
\text { Arvores }\end{array}$ \\
\hline Lewotobi & 1 & Lewotobi & $8^{\circ} 31^{\prime}$ & $122^{\circ} 46^{\prime}$ & 470 & E. alba & 10 \\
\hline Egon & 1 & Egon 2 & $8^{\circ} 40^{\prime}$ & $122^{\circ} 26^{\prime}$ & 700 & & 24 \\
\hline FLORES & 2 & & & & & & 34 \\
\hline \multirow[t]{2}{*}{ Adonara } & 2 & Waiwerang & $8^{\circ} 20^{\prime}$ & $123^{\circ} 15^{\prime}$ & 500 & E. alba & 3 \\
\hline & & Ileboleng & $8^{\circ} 21$ & $123^{\circ} 16^{\prime}$ & 500 & & 3 \\
\hline Lomblen & 1 & lleape & $8^{\circ} 18^{\prime}$ & $123^{\circ} 58^{\prime}$ & 700 & & 11 \\
\hline \multirow[t]{2}{*}{ Pantar } & 1 & Gulman & $8^{\circ} 23^{\prime}$ & $124^{\circ} 12^{\prime}$ & 560 & & 4 \\
\hline & & Palmen & & & & & \\
\hline \multirow[t]{2}{*}{ Alor } & 2 & Woipui & $8^{\circ} 16^{\prime}$ & $124^{\circ} 42^{\prime}$ & 400 & E. alba & 6 \\
\hline & & Raululang & $8^{\circ} 20^{\prime}$ & $124^{\circ} 30^{\prime}$ & 370 & & 4 \\
\hline OUTRAS & 6 & & & & & & 31 \\
\hline ILHAS & & & & & & & \\
\hline
\end{tabular}

Onde:

EMBRAPA = Empresa Brasileira de Pesquisa Agropecuária, Centro Nacional de Pesquisa de Florestas - CNPF, Colombo - PR .

CSIRO = Commonwealth Scientific and Industrial Research Organization, Canberra, ACT, Australia.

IPEF = Instituto de Pesquisas e Estudos Florestais, ESALQ/ Universidade de S.

Paulo, Piracicaba - SP. 


\section{1. 2 Experimentos Utilizados}

Este trabalho utilizou dois experimentos, separados por menos de $30 \mathrm{~km} \mathrm{em}$ condições ambientais praticamente iguais, conforme mapa 4:

\section{a) EXPERIMENTO 1:}

Teste de procedência e progênie de Eucalyptus urophylla - Ilha Flores (Indonésia). Sementes fornecidas pelo CNPF/ EMBRAPA, através da CSIRO Austrália, colheita do Cia. Vale do Rio Doce.

Localização: município de Bofete - SP, Latitude: $22^{\circ} 34 \mathrm{~S}$, Longitude $48^{\circ} 04 \mathrm{~W}$, altitude $520 \mathrm{~m}$.

Faz. Sta. Terezinha I - FST, Talhão 11, Região Ecológica da empresa : 1C.

\section{b) EXPERIMENTO 2 :}

Teste de Progênie de Eucalyptus urophylla - Outras Ilhas (Indonésia). Sementes oriundas de coleta seletiva de árvores do ideotipo "platyphylla" na E.E.C.F. de Anhembi - SP, pertencente à ESALQ/ USP, cuja origem foi de sementes fornecidas pela colheita da Cia. Vale do Rio Doce na Indonésia ( Vieira \& Bucsan, 1977).

Localização : município de Anhembi - SP. Latitude $22^{\circ} 36 \mathrm{~S}$. Longitude $48^{\circ} 06 \mathrm{~W}$, altitude $510 \mathrm{~m}$.

Faz. S. Judas I - FSJ, Talhão 09, Região Ecológica da empresa : 1C

\section{1. 3 Características edafoclimáticas}

O clima da região de experimentação, conforme a classificação de Köeppen, é Cwa , mesotérmico de inverno, com verão quente e chuvoso e inverno moderadamente frio e seco, com raras ocorrências de geadas. As temperaturas médias são:

$\mathrm{T}$ média anual $21^{\circ} \mathrm{C}$, mês mais quente, $24^{\circ} \mathrm{C}$, mês mais frio $16^{\circ} \mathrm{C}$. 
A precipitação média anual é de $1.310 \mathrm{~mm}$, variando entre 1.050 e $1.420 \mathrm{~mm}$, com as chuvas concentradas no verão, de dezembro a abril, e um período seco entre julho e setembro, atingindo um défice * hidrico ao redor de 50 - $70 \mathrm{~mm}$, mas com uma seca edáfica mais pronunciada nos horizontes superficiais, em função dos solos bastante arenosos.

A altitude da região está entre 550 e 600 m, estando próxima da cuesta formada pelo planalto da Serra de Botucatu ( 900 a 970 m ), que a margeia no sentido N-S, influenciando levemente o microclima local, mais seco que na serra.

Geomorfologicamente, a região pertence ao Médio Vale do Rio Tietê, com uma paisagem regional aplainada, originária do soerguimento de ambientes lacustres, de deposição de sedimentos de granulação média a fina, posteriormente retrabalhados pela erosão.

O relevo varia de suave ondulado a ondulado, com formação de colinas interligadas e vales rasos com encostas pouco ingremes. Os dois experimentos estão localizados nas cotas mais altas da região, em topos planos, onde praticamente não se verifica nenhuma forma de erosão, somente laminar leve.

Ocorre, porém, uma maior incidência de ventos que exercem seu maior efeito nos meses mais secos, aumentando a evapotranspiração. Alguns vendavais foram registrados e provocaram quebra de árvores, mas em níveis baixos considerados normais ( ver tabela no anexo 1, com a situação das árvores ).

Os solos predominantes são arenosos e profundos, derivados principalmente dos arenitos da Formação Pirambóia, classificados como LV - Latossolo VermelhoAmarelo distrófico, fase arenosa, em transição para AQ - Areia Quartzosa álica, com teores de argila e de nutrientes muito baixos, tradicionalmente usados para pastagens de baixo rendimento e silvicultura. Sem calagem e adubação, oferecem baixas respostas em produtividade e são muito facilmente lixiviados, conforme pode-se deduzir pelos dados da tabela 6.

Nota: défice está grafado corretamente, adaptado do latim. sendo preferivel a déficit. normalmente mais utilizado 
Tabela 6 : Características físico-químicas dos solos dos locais experimentais:

\begin{tabular}{|c|c|c|c|c|c|c|c|c|}
\hline EXPI SOLO & HORIZ. & $\begin{array}{c}\text { TEOR } \\
\text { ARGILA } \\
\% \\
\end{array}$ & $\mathrm{~K}$ & $\mathrm{Ca}$ & $\mathrm{Mg}$ & CTC & $\begin{array}{l}\mathrm{V} \\
\%\end{array}$ & $\begin{array}{c}\text { Mat. Org. } \\
\%\end{array}$ \\
\hline Exp.1AQ & $A$ & 8 & 0,09 & 0,1 & 0,1 & 3,2 & 9 & 1,4 \\
\hline Bofete - SP & $\mathrm{B}$ & 9 & 0,10 & 0,1 & 0,1 & 3,3 & 9 & \\
\hline Exp. 2 LV & $A$ & 15 & 0,23 & 0,3 & 0,1 & 4,1 & 13 & 1,6 \\
\hline Anhembi - SP & B & 17 & 0,19 & 0,2 & 0,1 & 3,8 & 12 & \\
\hline
\end{tabular}

obs: $\mathrm{K}, \mathrm{Ca}, \mathrm{Mg}$ e CTC em meq/ $100 \mathrm{~g}$ solo. $V \%=$ saturação por bases $(\mathrm{K}+\mathrm{Ca}+\mathrm{Mg} / \mathrm{CTC}$ )

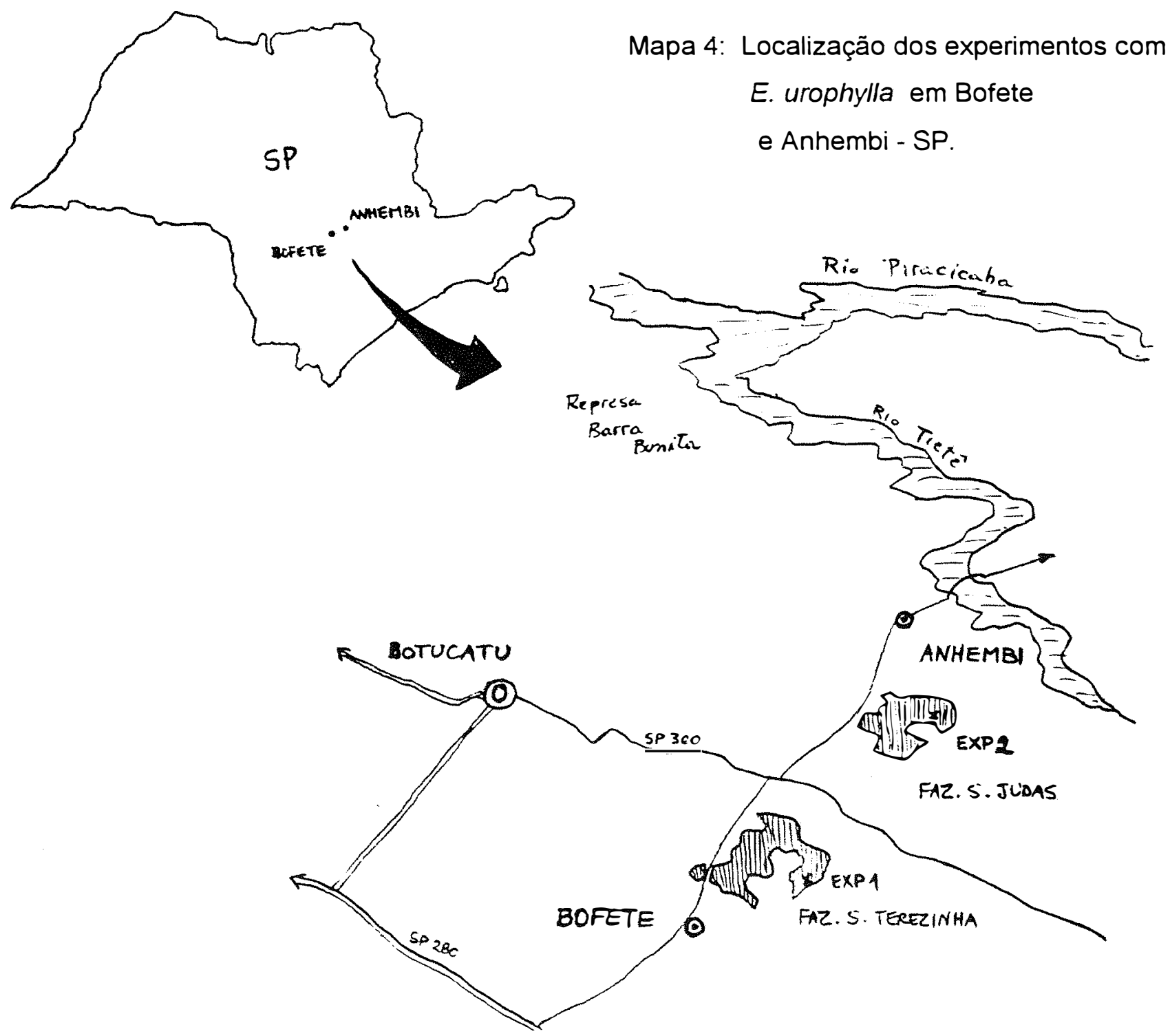




\section{2. MÉTODOS}

\subsubsection{Seleção do Material Genético}

Para o experimento 1, foram utilizadas sementes colhidas na Indonésia pela Cia. Vale do Rio Doce. Este Teste foi implantado como uma população base monoprocedência ( sentido amplo = ilha ) para selecionar, dentro de cada procedência ( sentido restrito = população), as árvores superiores em produção de madeira para formação de um Pomar de Sementes por Mudas - PSM, permitindo colher sementes recombinadas para novas gerações de melhoramento.

Para o experimento 2, a coleta das sementes foi feita em 1989 na Estação Experimental de Ciências Florestais - EECF de Anhembi - SP , da ESALQ -USP, no Teste de Procedência e Progênie de "Outras llhas" ( População base para recombinação entre matrizes das procedências de Alor, Pantar, Lomblem e Adonara). Neste teste foram selecionadas visualmente, por maior vigor, boa forma e boa frutificação, as 56 árvores superiores do padrão de casca lisa e clara, denominado na época como "platyphylla" , ou neste estudo, ideotipo casca lisa.

A partir dai foi plantado um novo teste ( que é o exp2), com o objetivo de formar uma população base multiprocedência, permitindo os benefícios da recombinação e a ampliação da variabilidade genética inicial. Visou-se selecionar em cada progênie as árvores superiores em produção de madeira para formação de um PSM - Pomar de Sementes por Mudas, onde houvesse uma frequência bem maior de árvores padrão "platyphylla", permitindo colher sementes recombinadas para novas gerações de melhoramento.

Ambos os experimentos estão inseridos no Programa 1 - Aumento da produtividade e melhoria da qualidade da madeira para produção de chapas de fibra, de acordo com os Programas e Projetos de Pesquisa da empresa Eucatex S.A.; estão cadastrados como Experimentos PP 14 FST e 15 FSJ. 


\section{2. 2 Produção de Mudas}

As sementes foram usadas ao natural, sem peneiramento, em semeadura manual com conchinhas metálicas. As mudas foram produzidas em bandejas de isopor sem tubetes, no sistema de torrões piramidais, com substrato organo-mineral, sem repicagem, com desbaste do excesso de plântulas por célula aos 25 dias, sem no entanto selecionar por vigor.

Esses cuidados foram observados para evitar qualquer seleção indesejada na fase de viveiro, visando manter a representatividade das amostras colhidas nas populações, considerando resultados como os de Mello et al. (1993). Estes autores comprovaram que para eucaliptos, o tipo de produção de mudas e especialmente a seleção das plântulas na fase de desbastes, afetam significativamente os testes de progênie aos 2 anos de idade, reduzindo diâmetro e volume e interferindo gravemente nos resultados e na seleção das progênies.

As mudas receberam adubações com NPK + micronutrientes durante toda a fase de crescimento, prevenindo deficiências e má formação de mudas. Aos 110 dias estavam maduras, com altura média de 30 a $40 \mathrm{~cm}$, aptas ao plantio no campo.

\section{2. 3 Plantio}

O plantio do experimento 1 no campo foi feito em 12 / 05 / 1991, adotando preparo de solo com grade bedding em camalhões, com adubação de base linear com MAP - monoamonio fosfato (NP 10-52-0), $150 \mathrm{~kg} / \mathrm{ha}$. As adubações de cobertura ocorreram aos 60 dias ( bórax $10 \mathrm{~g} /$ planta), aos 90 dias ( NK 17-0-10 com $200 \mathrm{Kg} / \mathrm{ha}$ ) e aos 120 dias ( fosfato acidulado parcialmente solúvel - FAPS $330 \mathrm{Kg} /$ ha, na entrelinha, incorporado com grade leve).

O plantio do experimento 2 no campo foi feito em 23 / 04 / 1990, adotando igualmente o preparo de solo com grade bedding em camalhões, com adubação de base linear com MAP - monoamonio fosfato (NK 10-52-0), $150 \mathrm{Kg} / \mathrm{ha}$. As adubações de cobertura também ocorreram aos 60 dias ( bórax $10 \mathrm{~g} /$ planta, aplicado em coroa) ; 
aos 90 dias ( NK 17-0-10 com $200 \mathrm{Kg} / \mathrm{ha}$ ) e aos 120 dias (fosfato acidulado FAPS $330 \mathrm{Kg} / \mathrm{ha}$, na entrelinha incorporado com grade leve).

\subsubsection{Manutenção}

A manutenção dos experimentos foi rigorosa, não permitindo em nenhum estágio de crescimento que houvesse matocompetição, já que existia a presença de capins invasores agressivos como braquiária. Foram feitas 2 capinas manuais e 2 mecanizadas no $1^{\circ}$ ano, além de aplicação de herbicida pós-emergente glifosate nas entrelinhas. A partir do fechamento das copas e do ano 2 ao 6 , foram feitas uma ou duas roçadas mecanizadas nas entrelinhas, além de controle químico de reboleiras com braquiária, visando impedir qualquer efeito ambiental localizado por matocompetição.

\subsubsection{Desbaste}

Visando executar os métodos de seleção definidos pela estratégia de melhoramento, para manter as populações estudadas sob acompanhamento e testar futuramente as sementes produzidas e os ganhos obtidos com a seleção a cada geração, foram programados desbastes sucessivos, aliando intensidade de seleção às caracteristicas de manejo silvicultural dessas populações.

Com base nos dados de 3 anos para o experimento 1, e 4 anos para 0 experimento 2 , foi realizado um desbaste eliminando as árvores inferiores à média da população. Aos 5 anos e aos 6 anos, respectivamente, será realizado novo desbaste, visando atigir um valor final próximo de 80 - $85 \%$ de árvores retiradas, ou seja, manter as melhores 15 a $20 \%$ melhores árvores para que se reproduzam. 


\section{2. 6 Delineamento Estatistico}

Os dois experimentos seguem o mesmo delineamento, em Blocos ao acaso, sendo:

Para o experimento 1:

Tratamentos: 34 Progênies casualizadas, sendo 24 progênies da procedência Mt. Egon e 10 progênies da procedência Mt. Lewotobi, com quatro repetições (blocos) e parcelas lineares de seis plantas, com espaçamento entre plantas de 3,0 x 2,0 m. Foi plantada uma bordadura dupla ao redor do experimento, utilizando uma mistura de mudas de todas as progênies. A área total é de 0,6 ha.

Para o experimento 2:

Tratamentos: 56 Progênies de matrizes de casca lisa da seleção feita na População Base de Outras Ilhas, com quatro repetições (blocos) e parcelas lineares de oito plantas, com espaçamento entre plantas de $3,0 \times 2,0 \mathrm{~m}$. Foi plantada uma bordadura dupla ao redor do experimento, que ocupou uma área total de 1,2 ha.

\section{2. 7. Coleta de dados}

- Dendrométricos : Foram medidos altura ( $H$, em m ) e Circunferência à Altura do Peito - CAP ( cm, para cálculo do diâmetro ) de todas as árvores em 3 idades, aos 3, 4 e 5 anos, no experimento 1 , e aos 4, 5 e 6 anos no experimento 2, utilizando Hipsômetro de Haga e Trena métrica, respectivamente. Foi anotada a sobrevivência ( árvores vivas), que gera a porcentagem de falhas, além de marcar as árvores que foram desbastadas.

Os dados foram armazenados em coletores eletrônicos marca Telxon e descarregados em microcomputadores 486 DX4 através de programas específicos, desenvolvidos pela empresa Unimicro - S. Paulo, para Inventário Florestal.

A partir da circunferência - CAP - foi calculado o DAP - diâmetro à altura do peito $(1,30 \mathrm{~m})$, com a fórmula $\mathrm{DAP}=\mathrm{CAP} / \pi$. 
Para calcular os volumes reais com casca ( volume por árvore, em $\mathrm{m}^{3} / \mathrm{arv}$ ), a equação volumétrica utilizada foi:

$$
V=\left(D A P^{2} \times \pi / 40.000\right) \times H \times f f \quad \text { onde DAP }(\mathrm{cm}), \mathrm{H}(\mathrm{m}) \text { e ff ( fator }
$$

de forma médio para inventário em $E$. urophylla ) $=0,45$

Extrapolou-se esse volume para hectare, para fins comparativos, usando: $V=$ $\mathrm{V}_{\text {arv }} \times 1.667$ arv/ha $\times(1-($ falha\% + desbaste\% / 100 $))$

- Morfológicos : Foram definidos e descritos os padrões considerados típicos da espécie, incluindo as variações botânicas descritas na literatura, com base em Martin \& Cossalter (1975), para os ítens casca do tronco e arquitetura da copa.

O tipo de folha predominante não foi determinado, pois em amostragens preliminares encontrou-se um gradiente sutil de formas de difícil separação, que exigiriam um trabalho detalhado específico para ser conclusivo, a nível taxonômico, o que se afastaria dos objetivos iniciais.

Nas árvores superiores, aos 5 e 6 anos de idade, foi possivel coletar frutos das árvores que já estavam se reproduzindo, para verificar o nível de variação existente e para compará-los com a literatura. Não foi possivel separar os frutos em classes e não foi encontrada nenhuma correlação morfológica com o tipo de casca, sendo este item, da mesma forma que o tipo de folha, simplesmente apresentado em anexo, como exemplo de variabilidade e do gradiente de formas.

Para suprir a deficiência de uma descrição de casca e arquitetura para árvores jovens, da mesma forma que adotado por Bienwagen, Luz \& Kleinig (1997) com híbridos de E. saligna, foi feita uma adaptação para as idades estudadas, quando as plantas ainda estão em processo de formação das características fenotípicas como casca e copa, resultando em três ideotipos:

1 - típicas do E. urophylla, com casca fibrosa e escura e folhas mais estreitas

2 - tipo platyphylla, com casca lisa e clara e folhas mais largas

3 - intermediárias, com casca rugosa e parda e folhas variadas 
Os individuos considerados atipicos nessa classificação puderam ser agrupados como o ideotipo platyphylla, por possuirem casca lisa e clara e folhas mais largas. No decorrer do trabalho de descrição e classificação, foi estabelecido mais um padrão fenotípico de árvores, consideradas como intermediárias, que diferiam das consideradas tipicas da espécie.

Este terceiro tipo foi descrito como de casca rugosa e parda, diferentes do platyphylla, mas que não podiam ser agrupadas com as árvores predominantes na população, as chamadas tipicas do $E$. urophylla, que tem casca fibrosa e escura e folhas mais estreitas.

Evitou-se uma abordagem muito analitica e detalhista quanto à Morfologia, pois outros trabalhos científicos como Martin \& Cossalter (1975 a e b); Potts(1986); López (1992); Pinyopusarerk (1993); Baez (1994); Pryor et al. (1995) comprovaram a imensa variabilidade dos detalhes, com amplo gradiente que dificulta estabelecer categorias intermediárias dentro da espécie ou a nivel de progênies. As caracteristicas foram anotadas em fichas apropriadas através de códigos e/ou descrições objetivas dos casos imprevistos.

1 - tipicas do E. urophylla

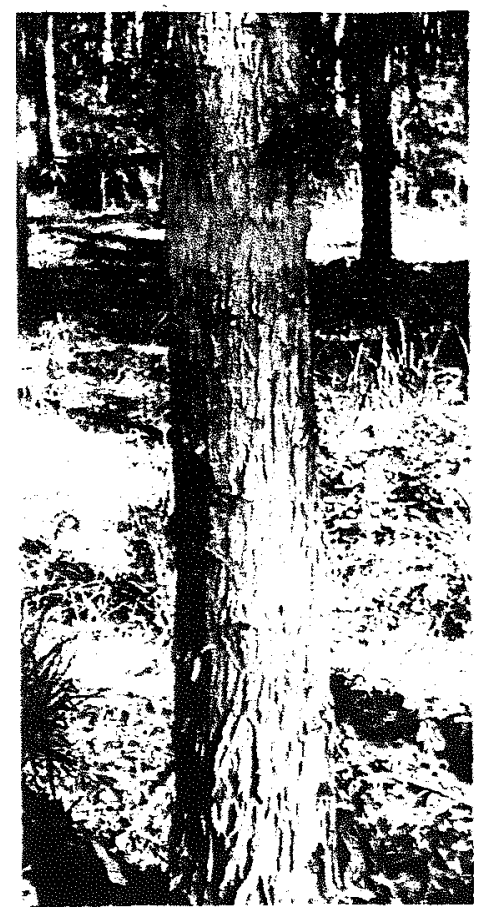

casca fibrosa e escura

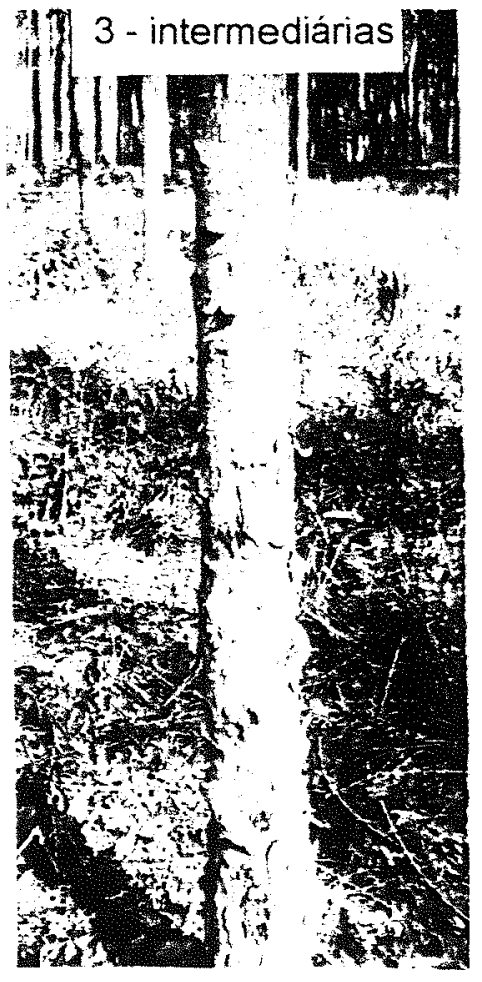

casca rugosa e parda

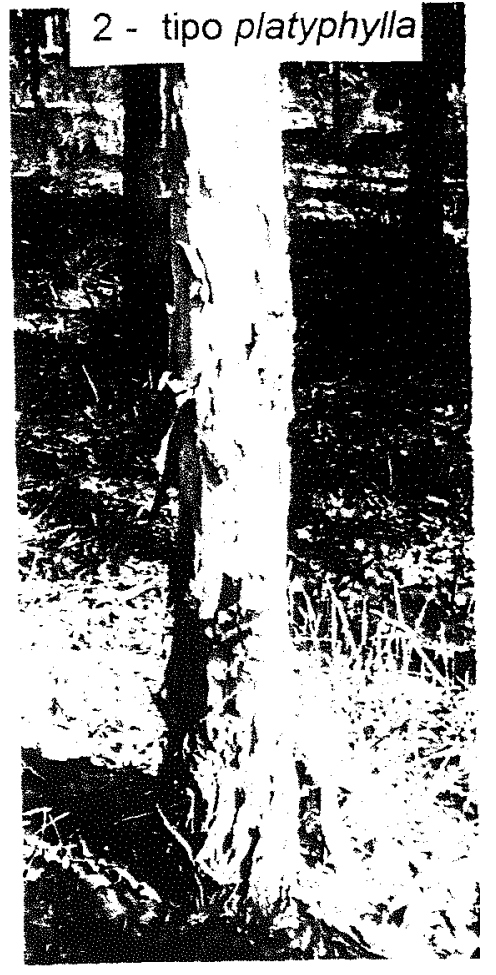

casca lisa e clara 
3. 2. 8. Metodologia para Análise Estatística dos dados dendrométricos

Os dois experimentos estudados são analisados antes e após a realização de desbastes seletivos, que visam transformá-los em Pomares de Sementes por Mudas PSM.

Como isto altera o número de árvores em cada parcela, desbalanceando os tratamentos, foi adotado um modelo matemático distinto para cada fase; ou seja, o modelo tradicionalmente apresentado para testes de progênie foi usado para os dados antes do desbaste, e outro modelo incluindo contrastes lineares foi aplicado após o desbaste, conforme apresentado a seguir.

Para o experimento 1, o modelo matemático adotado para análise dos dados antes do desbaste foi:

$$
y_{i j}=m+p_{i}+b_{j}+e_{i j} \text {, onde }
$$

$y_{i j}=$ valor observado na parcela que recebeu o tratamento "i" no bloco " $\mathrm{j}$ "; $\mathrm{m}=$ média geral sem efeito dos tratamentos ;

$p_{i}=$ é o efeito da progênie " $i$ " ;

$b_{j}=$ é o efeito do bloco "j";

$e_{i j}=$ é a contribuição do acaso.

A análise de variância foi feita ao nível de médias de parcelas, com a variância dentro de parcelas calculada a seguir com a média das variâncias dentro de parcelas ponderadas pelos seus graus de liberdade correspondentes, conforme adotado por Bueno Filho (1992) e Kageyama (1980). Ver tabela 7. 
Tabela 7 : Fórmulas para cálculo da análise de variância do experimento 1 aos 3 anos de idade, antes do desbaste. Eucalyptus urophylla, Bofete - SP, 1994.

\begin{tabular}{|c|c|c|c|c|}
\hline $\begin{array}{l}\text { Fonte de } \\
\text { Variação }\end{array}$ & GL & $G L$ & QM & $E(Q M)$ para médias \\
\hline Blocos & $b-1=B$ & 3 & & \\
\hline Progênies & $p-1=p$ & 33 & $Q p$ & $(1 / \tilde{n}) \sigma_{d}^{2}+\sigma_{e}^{2}+b \sigma_{p}^{2}$ \\
\hline Prog. $E X L$ & $g-1=G$ & 1 & & \\
\hline Residuo & $B \times P \times G$ & 99 & Qe & $(1 / \tilde{n}) \sigma_{d}^{2}+\sigma_{e}^{2}$ \\
\hline Dentro & & & Qd & $\sigma_{d}^{2}$ \\
\hline
\end{tabular}

onde: $\mathrm{b}$ é $\mathrm{o} \mathrm{n}^{\circ}$ de blocos ou repetições; $n$ é a média harmônica do $\mathrm{n}^{\circ}$ de árv/parcela, e os demais quadrados médios são irrelevantes para as estimativas procuradas.

Ainda para o experimento 1, o modelo matemático adotado para análise dos dados depois do desbaste foi:

$$
y_{i j}=m+p_{i}+b_{j}+\left(p_{i} X b_{j}\right)+e_{i j} \text {, onde }
$$

$\mathrm{y}_{\mathrm{ij}}=$ valor observado na parcela que recebeu o tratamento "i" no bloco "j";

$\mathrm{m}=$ média geral sem efeito dos tratamentos;

$p_{i}=$ efeito da progênie "i" ;

$b_{j}=$ efeito do bloco "j" ; $e_{i j}=$ contribuição do acaso.

As fórmulas para cálculo da análise de variância do experimento 1 , após 0 desbaste feito aos 3,2 anos de idade estão na tabela 8 . 
Tabela 8 : Fórmulas para cálculo da análise de variância do experimento 1 após o desbaste feito aos 3,2 anos de idade.Eucalyptus urophylla, Bofete-SP, 1994:

\begin{tabular}{|c|c|c|c|c|}
\hline $\begin{array}{l}\text { Fonte de } \\
\text { Variação }\end{array}$ & $\begin{array}{l}\text { Graus de } \\
\text { Liberdade }\end{array}$ & GL & QM & E (QM) para médias \\
\hline Blocos & $b-1=B$ & 3 & & \\
\hline Progênies & $p-1=p$ & 33 & Qp & $\sigma_{d}^{2}+n \cdot \sigma_{e}^{2}+b \sigma_{p}^{2}$ \\
\hline Blocos xProgên & $(b-1) \cdot(p-1)$ & 1 & & $\sigma_{d}^{2}+n \cdot \sigma_{e}$ \\
\hline Prog. $E \times L$ & $\begin{array}{c}(b-1) \cdot(p-1)= \\
B \times P\end{array}$ & 99 & & \\
\hline Resíduo & $\begin{aligned} T- & {[(B+P+G)+} \\
& (B \times P)]\end{aligned}$ & 628 & Qe & $\sigma_{d}^{2}+\sigma_{e}^{2}$ \\
\hline Dentro & & & Qd & $\sigma_{d}^{2}$ \\
\hline
\end{tabular}

onde: $b$ é o $n^{\circ}$ de blocos ou repetições; ñ é a média harmônica do $n^{\circ}$ de ár/parcela, e os demais quadrados médios são irrelevantes para as estimativas procuradas. $T=$ total

A análise pós-desbaste seguiu a orientação de Kanovski \& Nikles (1989), que propõe o uso de contrastes lineares para o caso de procedências e progênies desbalanceadas, ou seja, com números diferentes de árvores por parcela, em função do desbaste seletivo. Foram então montados os contrastes de interesse para cada uma das 2 procedências.

O desdobramento dos graus de liberdade dos tratamentos através desses contrastes lineares (ou ortogonais) obedeceu a sequência:

$$
\begin{aligned}
& Y_{E . L}=111111111111111111111111-2,4-2,4-2,4- \\
& 2,4 \quad-2,4 \quad-2,4 \quad-2,4 \quad-2,4 \quad-2,4 \quad-2,4
\end{aligned}
$$


onde $t_{1} a t_{24}=$ tratamentos são progênies da procedência Egon e $t_{25}$ a $t_{34}$ $=$ tratamentos referentes às progênies da procedência Lewotobi .

Para o experimento 2, o modelo matemático adotado para análise antes do desbaste foi :

$$
y_{i j}=m+p_{i}+b_{j}+e_{i j} \text {, onde }
$$

$y_{i j}=$ valor observado na parcela que recebeu o tratamento "i" no bloco "j" ;

$\mathrm{m}=$ média geral sem efeito dos tratamentos ;

$p_{i}=$ efeito da progênie "i" ;

$b_{j}=$ efeito do bloco "j";

$\mathrm{e}_{\mathrm{ij}}=$ contribuição do acaso.

Na tabela 9 é apresentado o esquema da análise de variância do experimento 2 aos 4 anos, antes do desbaste.

Tabela 9 : Esquema da análise de variância do experimento 2 aos 4 anos, antes do desbaste. Eucalyptus urophylla, Anhembi - SP, 1994:

\begin{tabular}{lcc}
\hline \multicolumn{1}{c}{ Fonte de Variação } & Graus de Liberdade & $G L$ \\
\hline Blocos & $(b-1)$ & 3 \\
Progênies & $(p-1)$ & 55 \\
Erro & $(b-1) \cdot(p-1)$ & 165 \\
\hline
\end{tabular}

Ainda para o experimento 2 , o modelo matemático adotado para análise dos dados depois do desbaste foi: 


$$
y_{i j}=m+p_{i}+b_{j}+\left(p_{i} \times b_{j}\right)+e_{i j} \text {, onde }
$$

$y_{i j}=$ valor observado na parcela que recebeu o tratamento "i" no bloco "j" ;

$\mathrm{m}=$ média geral sem efeito dos tratamentos;

$p_{i}=$ efeito da progênie "i" ;

$b_{j}=$ efeito do bloco "j";

$\mathrm{e}_{\mathrm{ij}}=$ contribuição do acaso.

O esquema da análise de variância do experimento 2 após o desbaste aos 4,5 anos de idade é apresentado na tabela 10.

Tabela 10 : Esquema da análise de variância do experimento 2 após o desbaste aos 4,5 anos de idade. Eucalyptus urophylla, Anhembi-SP, 1995:

\begin{tabular}{lcc}
\hline \multicolumn{1}{c}{ Fonte de Variação } & Graus de Liberdade & $G L$ \\
\hline Blocos & $b-1=B$ & 3 \\
Progênies & $p-1=P$ & 55 \\
Blocos X Progênies & $(b-1) \cdot(p-1)=B \times P$ & 165 \\
Erro & $T-(B+P+G)+(B \times P)$ & 674 \\
\hline
\end{tabular}

O experimento foi analisado em todos os parâmetros dendrométricos e genéticos nas idades de 4, 5 e 6 anos. Foi feita a análise descritiva dos dados de crescimento (altura total, DAP, Volume real por árvore e o estimado por ha ). Para estimar o volume por árvore real foi adotado o fator de forma igual a 0,45 que é uma média real de dados de plantios operacionais na mesma região. Entre as idades de 4 e 5 anos 
foi feito um desbaste para seleção de árvores superiores, sendo esta a melhor idade indicada por Rezende \& Bertolucci (1993).

Utilizou-se o Teste $F$ para detectar diferenças significativas entre progênies neste teste nas 3 idades, conforme descrito por Gomes (1990). A interação blocos X progênies foi adicionada ao modelo estatístico para controlar e avaliar o efeito do desbaste seletivo, de alto efeito ambiental e que causa grande desbalanceamento por não seguir um mesmo padrão em todas as parcelas.

\section{Estimação dos parâmetros genéticos}

As estimativas de variâncias genéticas e fenotípicas foram obtidas de operações diretas com os quadrados médios, com base em suas esperanças para o delineamento em blocos ao acaso, de acordo com Venkovsky (1987) e Bueno Filho (1992). As expressões correspondentes estão na tabela 11.

Tabela 11 : Estimativas de variâncias:

\begin{tabular}{|c|c|c|}
\hline Parâmetro & Símbolo & Estimativa \\
\hline Variância entre progênies & $\sigma_{p}^{2}$ & $(Q p-Q e) / b$ \\
\hline Variância aditiva & $\sigma_{a}^{2}$ & $4 \times Q p$ \\
\hline Variância intra classes & $\sigma_{y}^{2}$ & $Q p / b$ \\
\hline Variância do erro & $\sigma_{e}^{2}$ & $Q e-(Q d / \tilde{n})$ \\
\hline Variância dentro & $\sigma_{d}^{2}$ & Qd \\
\hline Variância fenotípica & $\sigma_{f}^{2}$ & $\sigma_{p}^{2}+\sigma_{e}^{2}+\sigma_{d}^{2}$ \\
\hline
\end{tabular}

Para estimar os componentes de variância foi usado o método REML, para volume por árvore nas idades de 4, 5 e 6 anos, usando o programa estatístico SAS (1990), concordando com Bouvet \& Vigneron, (1996), e ainda com Still \& Torrie (1980) que aplicaram esse método para experimentos com espécies florestais. 
Para os 2 experimentos em todas as idades, conforme proposto por Bienwagen et al. (1997), a análise estatística das variáveis DAP, altura e volume por árvore, incluiu uma análise de variância usando o Teste F e o Teste REGWF - teste de comparação múltipla de médias - (Einot \& Gabriel, 1975), a fim de detetar diferenças dendrométricas, estatisticamente significativas, entre as progênies, que são então classificadas em ordem decrescente de diâmetro (DAP) e de volume real por árvore.

No caso do experimento 1 , foi usada a técnica de contrastes lineares para comparar as progênies das 2 procedências (Egon $X$ Lewotobi), aplicando 0 procedimento estatístico da PROC GLM, método SS3 do SAS 6.09 para Unix, conforme proposto por Azais (1994) e adotado por Bouvet \& Vigneron (1996).

Foram elaboradas tabelas com os dados completos das populações e de todas as progênies. Também, para facilitar uma comparação visual dos extremos, são apresentadas tabelas resumo onde comparam-se as cinco melhores e as cinco piores progênies, para cada procedência. Verifica-se que esse número de cinco representa claramente os agrupamentos de significância realizados nos dois extremos da classificação, o que pode ser conferido nas tabelas do anexo 2.

Para atender às exigências dos testes estatísticos utilizados, foram aplicados:

- teste W de Shapiro \& Wilk (1965), para normalidade dos dados experimentais, feito pela PROC UNIVARIATE do SAS 6.09.

- teste de Box \& Cox (1964) para homogeneidade das variâncias dos tratamentos (progênies ).

Para adequar os dados experimentais às exigências do modelo estatístico, quando necessário foi utilizada a família de transformações estatísticas proposta por Box \& Cox (1964), onde:

$$
K=1-(b / 2) \quad \text { e } \quad Y^{\prime}=Y^{K}
$$

Houve transformação de dados apenas em duas variáveis do experimento 2 , transformando estatisticamente a altura pela quarta potência e o volume por árvore pela raiz quadrada. Após estas tranformações, obteve-se para todas as variáveis uma distribuição normal e homocedasticidade, de forma a atender corretamente às 
premissas para as análises de variância. Não foi necessário transformar dados para o experimento 1. Os detalhes estão apresentados no anexo 3.

\section{2. 9. - Metodologia da Análise Genética}

Para a realização da análise genética, inicialmente foram utilizados dados de DAP $(\mathrm{cm})$, referentes às idades de 3 anos no experimento 1 ( $F 1)$, e 4 anos no experimento 2 .

Para o cálculo dos coeficientes de herdabilidade, de seus erros associados, coeficientes de variação genético e coeficientes de variação fenotípica e os ganhos genéticos respectivos a seleção massal e sequencial, foram utilizadas as equações propostas por Vencovsky \& Barriga (1992).

Os coeficientes de herdabilidade para a seleção entre médias de progênies de meio-irmãos, seleção entre árvores individuais e seleção dentro de parcelas são, ainda conforme Venkovsky (1987):

$$
\begin{array}{ll}
\text { seleção ao nivel de médias de progênies: } & h^{2}{ }_{m}=\sigma_{p}^{2} / \sigma_{y}^{2} \\
\text { seleção de plantas individuais: } & h^{2}{ }_{i}=\sigma_{a}^{2} / \sigma_{f}^{2} \\
\text { seleção dentro de progênies: } & h^{2}{ }_{d}=3 \sigma_{p}^{2} / \sigma_{d}^{2}
\end{array}
$$

Os coeficientes de variação experimental ( CV \%), ao nivel de médias e os coeficientes de variação genéticos foram obtidos segundo Venkovsky (1987).

Foram usados diferenciais de seleção reais no cálculo de ganhos genéticos, diferente do comumente adotado que são diferenciais estimados. 
Para o cálculo do índice de seleção combinada e seu respectivo ganho genético utilizaram-se as equações propostas por Bueno Filho (1992):
1) $i=(x \operatorname{arv}-x p g) \cdot h^{2} m+(x \operatorname{arv}-x p g) \cdot h^{2} i$
2) $x i=\sum i / n$
e
$\wedge_{S} i=\sum(x i-i)^{2} / n-1$
3) $\quad \mathrm{i}>\mathrm{I}_{1}=\mathrm{xi}$
$\rightarrow \mathrm{DAP}_{1}$
$\mathrm{i}>\mathrm{I}_{2}=x \mathrm{i}+1^{\wedge} \mathrm{si}$
$\rightarrow \mathrm{DAP}_{2}$
$i>I_{3}=x i+2{ }^{\wedge} \mathrm{si}$
$\rightarrow \mathrm{DAP}_{3}$
4) $d s=D A P$ teste - DAP seleção
5) $\mathrm{Gi}=\left(h^{2}\right.$ indiv $) \cdot(\mathrm{ds}$ DAP $\rightarrow i)$

Para compôr os limites de seleção, foram utilizados os valores da média e desvio padrão da variável DAP (cm), em cada procedência do experimento 1 e a nivel de teste como um todo no experimento 2, para selecionar as árvores na seleção massal; e em cada progênie na seleção sequencial.

Para a seleção das árvores dentro das progênies utilizou-se o mesmo padrão ao nivel de cada progênie.

Na seleção combinada foram usados diferenciais de seleção reais, preferiveis ao método tradicional dos diferenciais tabelados. $O$ mesmo padrão foi utilizado ao nivel de procedência, mas a variável utilizada foi o indice proposto por Bueno Filho (1992):

$I_{i j k}=Y_{i} \ldots+q\left(Y_{i j k}-Y_{i j}\right)$

onde $q$ indica o peso relativo dado à seleção dentro de parcelas, quando comparado à seleção entre médias de progênies, sendo neste caso:

$$
q=\left(\frac{3 n b}{3+n b}\right) \cdot \sigma^{2} y / \sigma^{2} d
$$


A estimação dos componentes de variância foi feita pelo método REML, pois o método MIVQUE(0) (Minimum Variance Quadratic Unbiased Estimation) melhor comentado em Valério Filho (1991) e normalmente adotado, não se adaptou aos dados altamente desbalanceados após o desbaste, perdendo precisão.

Todas as equações e procedimentos estatisticos foram programados e calculados nos procedimentos do programa estatístico SAS ( Statistical Analytic System) versão 6.04 em microcomputadores Pentium 166 e 200. 


\section{4 - RESULTADOS \& DISCUSSÃO}

A análise está dividida em dois ítens: primeiro, o experimento 1, populações selvagens; depois, o experimento 2 , com a população recombinada e selecionada. Ao final, compara-se os resultados de ambas.

\section{1 - ANÁLISE DAS AMOSTRAS DAS POPULAÇÕES NATURAIS ( exp.1)}

A análise é feita antes da realização do desbaste (avaliando todas as árvores) e após o mesmo. Antes, com as populações ainda intocadas, foi possivel estimar os parâmetros genéticos em condições normais. A comparação entre os resultados anteriores e posteriores permite avaliar os efeitos causados pelos desbastes seletivos sobre os parâmetros dendrométricos.

Para satisfazer as premissas exigidas pela análise de variância e pelo teste de comparação de médias, não foi necessário transformar estatisticamente os dados das variáveis utilizadas para o exp1.

\subsection{1 - COMPORTAMENTO SILVICULTURAL}

- procedências, antes e após o desbaste

a) Antes do desbaste: a tabela 12 apresenta os dados da análise de variância das características altura, diâmetro e volume, aos 3 anos de idade. 
Tabela 12 : Análise de variância para o exp1 (procedências da llha Flores: Egon e Lewotobi ) aos 3 anos de idade. E. urophylla, Anhembi-SP.

\begin{tabular}{cccclc}
\multicolumn{2}{c}{ DAP : $\mathrm{m}=11,71 \mathrm{~cm}$} & $\mathrm{E}=11,57 \mathrm{~m}$ & $\mathrm{~L}=12,04 \mathrm{~cm}$ \\
\hline $\mathrm{FV}$ & $\mathrm{GL}$ & $\mathrm{QM}$ & $\mathrm{F}$ & Prob>F & CV exp \% \\
\hline 34 prog. & 33 & 2,890 & $1,71^{\star}$ & 0,023 & 11,11 \\
24 prog $\mathrm{E}$ & 23 & 2,386 & 1,53 & 0,088 & 10,77 \\
10 prog $\mathrm{L}$ & 9 & 3,802 & 1,84 & 0,107 & 11,94 \\
Contr $\mathrm{E}$ x $\mathrm{L}$ & 1 & 6,283 & 3,71 & 0,0571 & \\
4 blocos & 3 & 1,742 & 1,03 & 0,383 & \\
\hline Resid 34 $\mathrm{p}$ & 99 & 1,695 & & & \\
Res. pg $\mathrm{E}$ & 69 & 1,555 & & & \\
Res. pg $\mathrm{L}$ & 27 & 2,071 & & & \\
\hline
\end{tabular}

\begin{tabular}{|c|c|c|c|c|c|}
\hline$m=$ &, $55 \mathrm{~m}$ & & $=14,4$ & & $\mathrm{~L}=14,81 \mathrm{~m}$ \\
\hline $\mathrm{FV}$ & GL & QM & $\mathrm{F}$ & Prob $>F$ & CV $\exp \%$ \\
\hline 34 prog. & 33 & 2,905 & $1,55^{\star}$ & 0,049 & 9,39 \\
\hline $24 \operatorname{prog} E$ & 23 & 3,005 & $1,69^{\star}$ & 0,049 & 9,22 \\
\hline 10 prog $L$ & 9 & 2,563 & 1,17 & 0,354 & 10,01 \\
\hline Contr $E \times L$ & 1 & 3,691 & 1,97 & 0,163 & \\
\hline 4 blocos & 3 & 1,126 & 0,60 & 0,615 & \\
\hline Resid $34 p$ & 99 & 1,869 & & & \\
\hline Res. pg E & 69 & 1,776 & & & \\
\hline Res. pg L & 27 & 2,197 & & & \\
\hline
\end{tabular}

\begin{tabular}{|c|c|c|c|c|c|}
\hline \multicolumn{3}{|c|}{ VOL: $m=0,081 \mathrm{~m}^{3} / \mathrm{arv}$} & \multicolumn{2}{|c|}{$E=0,078 \mathrm{~m}^{3} / \mathrm{arv}$} & $L=0,088 \mathrm{~m}$ \\
\hline FV & GL & QM & $\mathrm{F}$ & Prob $>F$ & $C V \exp \%$ \\
\hline 34 prog. & 33 & 0,000737 & $2,08^{\star \star}$ & 0,003 & 23,20 \\
\hline $24 \operatorname{prog} E$ & 23 & 0,000463 & 1,58 & 0,074 & 21,86 \\
\hline 10 prog $L$ & 9 & 0,001191 & $2,29^{\star}$ & 0,047 & 25,80 \\
\hline Contr $\mathrm{E} \times \mathrm{L}$ & 1 & 0,002974 & $8,38^{* *}$ & 0,004 & \\
\hline 4 blocos & 3 & 0,000263 & 0,74 & 0,528 & \\
\hline Resid $34 p$ & 99 & 0,00035 & & & \\
\hline Res. pg $E$ & 69 & 0,00029 & & & \\
\hline Res. pg L & 27 & 0,00052 & & & \\
\hline
\end{tabular}


Antes do desbaste, aos 3 anos de idade, a tabela 12 mostra as diferenças significativas encontradas em dois niveis ( * a $5 \%$ e ** a $1 \%$ de probabilidade ) entre as procedências Egon e Lewotobi, para as características diâmetro, altura e volume.

Para diâmetro - DAP (cm), houve diferença significativa ( * ) entre todas as 34 progênies agrupadas. Não houve diferença entre as progênies dentro das procedências, nem entre as 2 procedências.

Para altura $(m)$, houve diferença significativa ( * ) entre as progênies de Egon, ou seja, dentro dessa procedência, e quando todas as 34 progênies foram agrupadas. Não houve diferença entre as progênies de Lewotobi, nem entre as procedências.

Para volume real ( $\mathrm{m} 3$ / arv) foi encontrada diferença altamente significativa ( ${ }^{\star}$ ) entre procedências ( contraste $E \times L$ ) e, portanto, entre suas progênies quando agrupadas. Houve diferença significativa ( ${ }^{*}$ ) entre as progênies de Lewotobi, ou seja, dentro dessa procedência. Não houve diferença entre as progênies de Egon.

Analisando os coeficientes de variação experimental, para diâmetro e altura estão em nivel adequado, ao redor de $10 \%$ ou menos, indicando boa eficiência experimental, com baixa interferência de erros e, portanto, boa confiabilidade.

As diferenças absolutas entre os tratamentos ( melhor $X$ pior progênie), conforme mostram os dados completos nas tabelas e do anexo 1, na procedência Lewotobi, são de $31 \%$ para diâmetro e 76 \% para volume real. Na procedência Egon estes valores são de $31 \%$ para diâmetro e $78 \%$ para volume, mostrando um comportamento praticamente igual. Para o experimento todo, as mesmas comparações são de 36 \% entre diâmetros e $95 \%$ entre volumes, demonstrando o alto nivel de variação e o bom potencial a ser explorado pelo melhoramento nesses materiais da llha Flores.

b ) Após o desbaste: as tabelas 13 e 14 relacionam os dados da análise de variância das caracteristicas altura, diâmetro ( DAP ) e volume, aos 4 e 5 anos de idade, para o exp.1. 
Tabela 13 : Análise de variância para o exp1( procedências da llha Flores: Egon e Lewotobi) aos 4 anos de idade. E. urophylla, Anhembi-SP.

\begin{tabular}{|c|c|c|c|c|c|}
\hline \multirow{2}{*}{$\begin{array}{r}\text { DAP } \\
F V\end{array}$} & \multicolumn{2}{|c|}{$=15,18 \mathrm{~cm}$} & \multicolumn{2}{|c|}{$E=14,96 m$} & \multirow{2}{*}{$\begin{array}{r}L=15,68 \mathrm{~m} \\
\mathrm{cV} \exp \%\end{array}$} \\
\hline & GL & QM & $\mathrm{F}$ & Prob $>F$ & \\
\hline 34 prog. & 33 & 5,180 & 1,41 & 0,072 & 14,11 \\
\hline 24 prog $E$ & 23 & 3,281 & 0,94 & 0,546 & 15,04 \\
\hline 10 prog $L$ & 9 & 5,367 & 1,32 & 0,235 & 11,13 \\
\hline Contr $E \times L$ & 1 & 40,299 & $10,98^{\star \star}$ & 0,001 & \\
\hline bloc $\times$ prog & 99 & 4,573 & 1,25 & 0,081 & \\
\hline 4 blocos & 3 & 2,080 & 0,57 & 0,063 & \\
\hline Resid $34 p$ & 307 & 3,668 & & & \\
\hline Res.pgE & 212 & 3,493 & & & \\
\hline Res.pg L & 95 & 4,058 & & & \\
\hline \multicolumn{3}{|c|}{$H: \quad m=17,95 m$} & \multicolumn{2}{|c|}{$E=17,80 \mathrm{~m}$} & $L=18,31 \mathrm{~m}$ \\
\hline $\mathrm{FV}$ & GL & QM & $\mathrm{F}$ & Prob $>F$ & $C V \exp \%$ \\
\hline 34 prog. & 33 & 5,554 & $3,92^{\star \star}$ & 0,0001 & 10,70 \\
\hline $24 \operatorname{prog} E$ & 23 & 4,148 & $3,05^{\star \star}$ & 0,0001 & 10,11 \\
\hline 10 prog $L$ & 9 & 6,776 & $4,40^{\star \star}$ & 0,0001 & 11,12 \\
\hline Contr $E \times L$ & 1 & 19,330 & $13,65^{\star \star}$ & 0,0003 & \\
\hline bloc $\times$ prog & 99 & 3,693 & $2,61^{\star \star}$ & 0,0001 & \\
\hline 4 blocos & 3 & 2,250 & 1,59 & 0,1919 & \\
\hline Resíd $34 p$ & 307 & 1,415 & & & \\
\hline Res.pg E & 212 & 1,359 & & & \\
\hline Res. pg L & 95 & & & & \\
\hline \multicolumn{3}{|c|}{ VOL: $m=0,150 \mathrm{~m}^{3} / \mathrm{arv}$} & \multicolumn{2}{|c|}{$E=0,144 \mathrm{~m}^{3} / \mathrm{arv}$} & $L=0,163 \mathrm{~m}$ \\
\hline $\mathrm{FV}$ & $G L$ & QM & $\mathrm{F}$ & Prob $>F$ & $C V \exp \%$ \\
\hline 34 prog. & 33 & 0,003996 & $2,09^{\star \star}$ & 0,0007 & 33,20 \\
\hline 24 prog $E$ & 23 & 0,002246 & 1,46 & 0,0873 & 35,84 \\
\hline 10 prog $L$ & 9 & 0,005195 & 1,89 & 0,0625 & 26,18 \\
\hline Contr $E \times L$ & 1 & 0,025794 & $13,48^{\star \star}$ & 0,0003 & \\
\hline bloc $\times$ prog & 99 & 0.002487 & $1,30^{\star}$ & 0,0479 & \\
\hline 4 blocos & 3 & 0,00114 & 0,60 & 0,6181 & \\
\hline Resíd $34 p$ & 307 & 0,00191 & & & \\
\hline Res. pg E & 212 & 0,00154 & & & \\
\hline Res.pg L & 95 & 0,00274 & & & \\
\hline
\end{tabular}


Tabela 14: Análise de variância para o exp1(procedências da llha Flores: Egon e Lewotobi) aos 5 anos de idade. E. urophylla, Anhembi-SP.

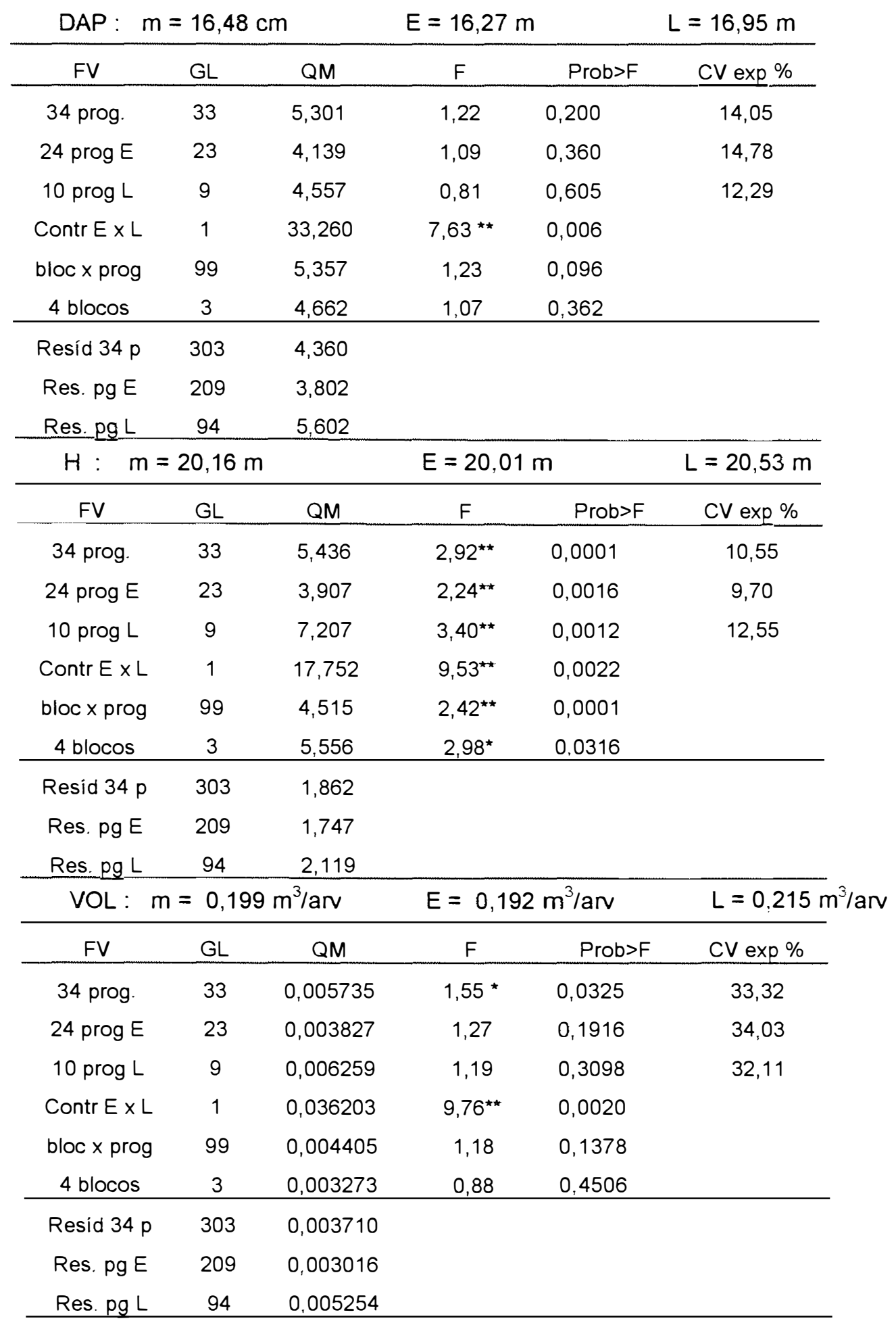


Após o desbaste, as tabelas 13 e 14 demonstram as diferenças significativas observadas em dois níveis ( ${ }^{*}$ a $5 \%$ e ** a $1 \%$ de probabilidade ) entre as procedências Egon e Lewotobi, para as características diâmetro (DAP), altura e volume real, para duas idades.

Aos 4 anos de idade ( 1 ano após o desbaste, tabela 13 ):

Para diâmetro - DAP $(\mathrm{cm})$, houve diferença altamente significativa ( ${ }^{\star \star}$ ) entre as 2 procedências ( contraste $E \times L$ ). Não houve diferença entre as progênies dentro de cada procedência, nem entre todas as 34 progênies agrupadas. Não houve significância para a interação bloco X progênie.

Para altura total $(m)$, encontrada diferença altamente significativa ( **) entre todas os tratamentos testados, ou seja, entre e dentro de procedências, e quando todas as 34 progênies foram agrupadas. Também houve diferença altamente significativa ( ${ }^{* \star}$ ) para a interação bloco X progênie, mostrando a influência diferencial do desbaste entre os tratamentos ( reações distintas entre as progênies ).

Para volume real ( $\mathrm{m} 3$ / arv), houve diferença altamente significativa ( ${ }^{* \star}$ ) entre procedências ( contraste $E \times L$ ) e, portanto, entre suas progênies quando agrupadas. Encontrada diferença significativa ( ${ }^{*}$ ) para a interação bloco $X$ progênie, mostrando a influência diferencial do desbaste entre os tratamentos, porém menor do que para altura. Não houve diferença entre as progênies dentro das procedências.

Portanto, a altura foi a característica mais influenciada pelo desbaste, seguida pelo volume real com casca por árvore. O diâmetro ( DAP ) sofreu o menor efeito em um ano após o desbaste próximo de $50 \%$.

Aos 5 anos de idade ( 2 anos após o desbaste, tabela 14):

Para diâmetro - DAP, manteve-se igual ao ano anterior, ou seja, com diferença altamente significativa $\left({ }^{\star *}\right)$ entre as 2 procedências (contraste $E \times L$ ). Não houve diferença entre as progênies dentro de cada procedência, nem entre todas as 34 progênies agrupadas. Não houve significância para a interação bloco X progênie. 
Para altura também mostrou-se igual ao ano anterior, com diferença altamente significativa ( ${ }^{* *}$ ) entre todas os tratamentos testados, ou seja, entre e dentro de procedências, e quando todas as 34 progênies foram agrupadas. Também houve diferença altamente significativa para a interação bloco $X$ progênie, evidenciando a influência diferencial do desbaste entre os tratamentos ( reações distintas entre as progênies ).

Para volume real houve diferença altamente significativa $\left({ }^{\star \star}\right)$ entre procedências ( contraste $E \times L$ ), mas a um nivel menor entre todas as progênies se agrupadas. Não houve diferença para a interação bloco $X$ progênie, nem entre as progênies dentro das procedências.

Novamente a altura foi a caracteristica mais influenciada pelo desbaste, que afetou menos o volume e o diâmetro após dois anos do corte de quase 50 \% das piores árvores.

Comparando as 2 idades após o desbaste, nota-se que há uma tendência geral de queda da influência diferencial do desbaste sobre as árvores remanescentes, pois as significâncias vão se reduzindo, e os valores das probabilidades aumentam. Isto pode ser interpretado como um retorno gradativo da competição, que passa a agir cada vez mais sobre a totalidade das árvores, que nesses dois anos já ocuparam os espaços vazios. Muitos indivíduos que retomaram crescimento livre voltam a competir.

A procedência Lewotobi, que sempre apresentou as maiores médias de crescimento, pode ser considerada superior pelas análises de variância. Após o desbaste, ou seja, a partir dos 4 anos, mostra diferenças altamente significativas ao nível de procedência, para médias de altura, volume real por árvore e DAP.

As mesmas análises dentro das 2 procedências mostraram diferença significativa entre as médias de progênies somente para altura, não sendo significativas as diferenças para diâmetro e volume.

Devido ao efeito uniformizador do desbaste, mesmo ocorrendo diferenças significativas entre as médias das progênies, constatou-se uma forte redução da amplitude de variação para todas as características. As comparações entre os extremos dessas médias e os valores porcentuais estão na tabela 15. 
Tabela 15: Efeito do desbaste sobre valores extremos de diâmetro (DAP), altura e volume e comparação porcentual. Médias de progênies de E. urophylla em Bofete-SP.

\begin{tabular}{ccccccc}
\hline Idade & \multicolumn{2}{c}{ DAP } & \multicolumn{2}{c}{ altura } & \multicolumn{2}{c}{ volume } \\
anos & $\mathrm{cm}$ & $\%$ & $\mathrm{~m}$ & $\%$ & $\mathrm{~m} 3 / \mathrm{arv}$ & $\%$ \\
\hline 3 & $14,1-10,3$ & 36 & $16,8-13,0$ & 28 & $0,125-0,064$ & 95 \\
4 & $16,6-13,6$ & 22 & $19,3-17,0$ & 13 & $0,195-0,124$ & 57 \\
5 & $17,9-15,5$ & 15 & $21,4-18,9$ & 13 & $0,248-0,171$ & 45 \\
\hline
\end{tabular}

Entre 3 e 5 anos, devido ao desbaste, houve grande redução da amplitude de variação: para diâmetro reduziu-se de $36 \%$ para $15 \%$; para altura, caiu de $28 \%$ para $13 \%$, e para volume diminuiu de $95 \%$ para $45 \%$.

Em apenas um ano já recomeça uma estratificação entre e dentro das progênies, principalmente em volume, cuja diferença entre as médias extremas passa dos $95 \%$ aos 3 anos para $57 \%$ aos 4 anos. Em mais um ano, esta mesma diferença média cai para $45 \%$, conforme ainda os dados completos dos anexos 1 e 2 .

Dentro de cada procedência existem progênies que mantém a mesma taxa de crescimento normal e outras que se destacam por serem mais responsivas à redução da competição. Isto pode ser chamado de efeito diferencial do desbaste, ou resposta diferencial das progênies, ou mesmo uma indicação de interação genótipo $X$ ambiente, por abertura indireta do espaçamento. Em média, com o desbaste próximo de $50 \%$, houve uma duplicação da área por planta ( passando de 6 para $12 \mathrm{~m}^{2} / \mathrm{arv}$ ).

Desde os 3 anos de idade algumas progênies se destacam, com potencial de crescimento acima das demais (progênies 26, 27, e 32, todas de Lewotobi, e 3 e 22, de Egon ) ou muito abaixo ( progênies 1, 5,24 e 13, todas de Egon). A lista completa da classificação das progênies pelo teste REGWF está no anexo 2.

Antes do desbaste, tanto os valores de CV experimental, como os de CV para crescimento em DAP e altura correspondem ao citado em literatura ( Pinto Jr, 1984 ; Mori et al., 1988 ) para a região de Anhembi-SP, que é muito próxima e semelhante 
ao local da experimentação (Bofete-SP), com pequena vantagem de crescimento para este teste, conforme Luz et al. (1996). Isto pode ser atribuído a uma melhor nutrição (foram feitas calagem e várias adubações completas), resultando numa resposta maior e mais rápida. Após o desbaste, aos 4 anos houve acréscimos nos CVs experimentais e apareceu diferença significativa $\left(^{*}\right)$ para blocos, devido a um desbalanceamento causado pelo desbaste seletivo. Entretanto, isto desaparece aos 5 anos indicando um retomo às condições normais com o passar do tempo.

Observa-se que na idade mais jovem, ou antes da interferência do desbaste, só o volume revelou diferenças significativas, exceto dentro da procedência Egon, que mostrou diferenças em altura. A $5 \%$ de significância, houve diferença para diâmetro e altura para o agrupamento geral das duas procedências, considerando-as como uma só origem - Ilha Flores.

Para o diâmetro, apesar das altas diferenças dendrométricas absolutas apresentadas entre os tratamentos, estatisticamente não se comprovou nenhuma significância entre ou dentro de procedências. As maiores respostas ocorreram sempre em altura, que se mostrou o parâmetro que melhor avaliou a resposta aos desbastes nessas idades jovens ( 3 a 5 anos).

Mas a nivel de toda a população testada, ou seja, Ilha Flores como um todo, há diferenças para diâmetro e altura, o que permite classificar todas as progênies conjuntamente, levando em conta que não haverá barreiras de distância para a recombinação entre os genótipos do teste (delineamento de blocos ao acaso, progênies das 2 procedências misturadas ).

Analisando o comportamento silvicultural a nivel de procedência, a tabela 16 apresenta um resumo comparativo por idades. 
Tabela 16: Estatísticas básicas (descritivas) ao nível de procedência, aos 3, 4 e 5 anos de idade, para o experimento 1: E urophylla, Bofete-SP, 1994.

\begin{tabular}{|c|c|c|c|c|c|c|c|c|}
\hline Idade & $\mathrm{N}^{0}$ árvs & $\begin{array}{l}\text { Falh } \\
+ \text { desb } \\
(\%)\end{array}$ & $\begin{array}{l}\text { Altura } \\
(\mathrm{m})\end{array}$ & $\begin{array}{l}\text { DAP } \\
(\mathrm{cm})\end{array}$ & $\begin{array}{c}\text { Volume } \\
\text { real } \\
\left(\mathrm{m}^{3} / \mathrm{arv}\right)\end{array}$ & $\begin{array}{c}\text { Volume } \\
\text { real } \\
\left(\mathrm{m}^{3} / \mathrm{ha}\right)\end{array}$ & $\begin{array}{l}\text { CV } \\
\text { DAP } \\
(\%)\end{array}$ & $\begin{array}{l}\text { CV } \\
\text { Alt } \\
\text { (\%) }\end{array}$ \\
\hline Proced & Lewotobi & & & & & & & \\
\hline 3 & 226 & 6 & 14,81 & 12,04 & 0,088 & 141,8 & 27,3 & 21,6 \\
\hline 4 & 134 & 44 & 18.31 & 15,68 & 0,163 & 152,8 & 12,6 & 8,4 \\
\hline 5 & 133 & 44 & 20,53 & 16,95 & 0,215 & 201,3 & 13,7 & 8,8 \\
\hline Proced & Egon & & & & & & & \\
\hline 3 & 558 & 3 & 14,45 & 11.57 & 0,078 & 126,6 & 26,2 & 20,8 \\
\hline 4 & 305 & 47 & 17,80 & 14,96 & 0,144 & 128,2 & 12,1 & 7,9 \\
\hline 5 & 304 & 47 & 20,01 & 16.27 & 0,192 & 170,5 & 13,8 & 8,6 \\
\hline Geral & Ilha Flores & & & & & & & \\
\hline 3 & 784 & 47 & 14,55 & 11,71 & 0,081 & 131,1 & 27,9 & 22,1 \\
\hline 4 & 439 & 46 & 17,95 & 15,18 & 0,150 & 135,4 & 12,9 & 8,8 \\
\hline 5 & 437 & 46 & 20,16 & 16,48 & 0,199 & 179,0 & 14,6 & 9,3 \\
\hline
\end{tabular}

onde: volume estimado por ha $=$ vol. cil. $X(F . F=0,45) \times(1667 \times \%$ de sobrevivência $)$.

Comparando as produtividades das procedências, em termos de volume por árvore, Lewotobi é $13 \%$ maior que Egon aos 3 anos. Essa superioridade se mantém em $12 \%$ aos 5 anos. A mesma comparação em volume por hectare, aos 3 anos, revela $12 \%$ a mais para Lewotobi, que aos 5 anos continua superando Egon, só que em $18 \%$, numa tendência crescente.

Isto mostra que após o desbaste, as árvores de Lewotobi podem ser consideradas mais responsivas que as de Egon, por terem aumentado seu ritmo de crescimento. Outra forma de avaliar o desempenho das procedências seria através do incremento médio anual - IMA - calculando com os dados da tabela 16. Porém, este dado é ilustrativo, meramente uma extrapolação para hectare. O IMA para Lewotobi era de 47,2 $\mathrm{m}^{3} /$ ha.ano e 2 anos após o desbaste ficou em 40,3, representando uma redução de $85,4 \%$, enquanto Egon sofreu uma redução de 80,8 \%. Deste ponto de 
vista, como a procedência Egon tinha maior proporção de material genético inferior, a eliminação das piores árvores beneficiou mais as médias finais do que em Lewotobi.

\section{Efeito ambiental $X$ falhas}

O E. urophylla suportou a seca acentuada do ano anterior à medição (1994 ) praticamente 5 meses sem chuvas entre julho e novembro - de uma forma muito melhor do que o $E$. saligna, que conta com um teste de progênie próximo. Houve 6,1 $\%$ de falhas + mortas na procedência do $\mathrm{Mt}$. Lewotobi e 8,3\% na procedência do $\mathrm{Mt}$. Egon, contra uma média de $25 \%$ de falhas e mortas no teste de espaçamento e progênie de $E$. saligna, com mesma idade e sob idênticas condições edafoclimáticas.

Como a espécie $E$. saligna sempre foi a preferida para os plantios na região, sendo na maior parte substituída pelo $E$. grandis, a ótima resistência do $E$ urophylla à seca comprova o seu potencial adaptativo a ser aproveitado. Deve-se lembrar que a sua alta capacidade de brotação também deverá contribuir muito para que esta espécie venha a ser adotada como boa alternativa para condução da rebrota para 3 rotações. Neste particular, dados operacionais para plantios de $E$. grandis sobre solos arenosos, revelam que apesar da maior produtividade no $1^{\circ}$ corte, a regeneração é ruim com alto porcentual de falhas, e isto se agrava para o corte na estação seca, chegando mesmo a inviabilizar a $2^{\mathrm{a}}$ rotação.

- progênies, antes e após o desbaste

Apenas para facilitar as comparações, as tabela 17, 18 e 19 apresentam as médias das cinco melhores e das cinco piores progênies, classificadas pelo teste REGWF em volume por árvore para as três idades; obviamente, os estudos completos consideraram toda a população. As listagens completas estão no anexo 2. 
Tabela 17 - Classificação pelo teste REGWF das cinco melhores e cinco piores progênies por procedência, em volume médio por árvore, aos 3 anos de idade, para 0 exp1 ( procedências da llha Flores: Egon e Lewotobi). E. urophylla, Anhembi-SP.

melhores progênies 3 anos

\begin{tabular}{|c|c|c|c|c|c|c|c|c|}
\hline CLASSIF. & PROGENIE & $\begin{array}{c}\text { FALHA } \\
\%\end{array}$ & $\begin{array}{r}\text { ALT } \\
(m)\end{array}$ & $\begin{array}{c}\text { CV } \\
\text { ALT } \\
\%\end{array}$ & DAP & DAPQ & $\begin{array}{c}\text { CV } \\
\text { DAP } \\
\%\end{array}$ & $\begin{array}{l}\text { VOL real } \\
\text { m3/an }\end{array}$ \\
\hline \multicolumn{9}{|l|}{ Egon } \\
\hline 1 & 22 & 8 & 16.0 & 9.3 & 13.6 & 13.8 & 14.6 & 0.114 \\
\hline 2 & 2 & 4 & 15.3 & 8.8 & 12.9 & 13.0 & 14.6 & 0.095 \\
\hline 3 & 6 & 8 & 16.0 & 9.2 & 12.4 & 12.6 & 17.2 & 0.087 \\
\hline 4 & 3 & 8 & 14.1 & 10.3 & 12.3 & 12.5 & 18.2 & 0.087 \\
\hline 5 & 20 & 4 & 14.9 & 15.6 & 12.0 & 12.4 & 24.0 & 0.087 \\
\hline$x$ & $x$ & 7 & 15.3 & 10.7 & 12.6 & 12.8 & 17.7 & 0.094 \\
\hline \multicolumn{9}{|l|}{ Lewotob } \\
\hline 6 & 26 & 0 & 16.8 & 23.8 & 14.2 & 14.5 & 21.4 & 0.125 \\
\hline 7 & 27 & 8 & 15.6 & 21.7 & 13.0 & 13.6 & 29.6 & 0.107 \\
\hline 8 & 32 & 0 & 15.3 & 14.9 & 12.3 & 12.6 & 25.2 & 0.095 \\
\hline 9 & 30 & 4 & 15.4 & 27.6 & 11.8 & 12.4 & 32.9 & 0.085 \\
\hline 10 & 28 & 4 & 15.2 & 16.3 & 11.9 & 12.2 & 22.3 & 0.082 \\
\hline$x$ & $x$ & 3 & 15.7 & 20.9 & 12.6 & 13.0 & 26.3 & 0.099 \\
\hline \multicolumn{9}{|l|}{ piores } \\
\hline CLASSIF. & PROGENIE & $\begin{array}{c}\text { FALHA } \\
\%\end{array}$ & $\begin{array}{r}\text { ALT } \\
(m)\end{array}$ & $\begin{array}{c}C V \\
A L T \\
\%\end{array}$ & DAP & DAPQ & $\begin{array}{c}\text { CV } \\
\text { DAP } \\
\%\end{array}$ & $\begin{array}{c}\text { VOL real } \\
\mathrm{m} 3 / \mathrm{ar}\end{array}$ \\
\hline \multicolumn{9}{|l|}{ Egon } \\
\hline 1 & 5 & 4 & 13.5 & 22.0 & 10.4 & 11.0 & 33.2 & 0.064 \\
\hline 2 & 12 & 4 & 13.7 & 23.6 & 10.8 & 11.2 & 29.7 & 0.065 \\
\hline 3 & 18 & 4 & 13.2 & 32.7 & 10.4 & 11.1 & 39.0 & 0.067 \\
\hline 4 & 21 & 4 & 13.0 & 34.7 & 11.1 & 11.6 & 30.9 & 0.068 \\
\hline 5 & 23 & 8 & 13.9 & 19.8 & 11.0 & 11.4 & 29.2 & 0.070 \\
\hline$x$ & $x$ & 5 & 13.5 & 26.6 & 10.7 & 11.3 & 32.4 & 0.067 \\
\hline \multicolumn{9}{|l|}{ Lewotob } \\
\hline 6 & 29 & 0 & 13.6 & 21.9 & 11.1 & 11.6 & 29.8 & 0.071 \\
\hline 7 & 25 & 7 & 14.0 & 29.6 & 10.8 & 11.5 & 38.0 & 0.075 \\
\hline 8 & 31 & 8 & 14.7 & 18.5 & 11.4 & 11.8 & 28.6 & 0.078 \\
\hline 9 & 33 & 8 & 14.3 & 18.0 & 11.6 & 12.0 & 25.9 & 0.078 \\
\hline 10 & 34 & 8 & 14.7 & 20.4 & 11.7 & 12.0 & 25.3 & 0.079 \\
\hline$x$ & $x$ & 8 & 14.2 & 21.7 & 11.3 & 11.8 & 29.5 & 0.076 \\
\hline
\end{tabular}


Tabela 18 - Classificação pelo teste REGWF das cinco melhores e cinco piores progênies por procedência, em volume médio por árvore, aos 4 anos de idade, para o exp1 (procedências da Ilha Flores: Egon e Lewotobi). E. urophylla, Anhembi-SP. melhores progênies 4 anos

\begin{tabular}{|c|c|c|c|c|c|c|c|c|}
\hline \multirow[t]{3}{*}{ CLASSIF. } & \multirow[t]{3}{*}{ PROGENIE } & \multirow{3}{*}{$\begin{array}{c}\text { FALHA } \\
\%\end{array}$} & \multirow{3}{*}{$\begin{array}{l}\text { ALT } \\
(m)\end{array}$} & \multirow{2}{*}{$\begin{array}{l}\text { CV } \\
\text { ALT }\end{array}$} & \multirow{3}{*}{$\begin{array}{l}\text { DAP } \\
(\mathrm{cm})\end{array}$} & \multirow[t]{3}{*}{$\mathrm{DAPQ}$} & \multirow{3}{*}{$\begin{array}{c}\text { CV } \\
\text { DAP \% }\end{array}$} & \multirow{3}{*}{$\begin{array}{l}\text { VOL real } \\
\text { m3/an }\end{array}$} \\
\hline & & & & & & & & \\
\hline & & & & & & & & \\
\hline \multicolumn{9}{|l|}{ Egon } \\
\hline 1 & 22 & 29 & 18.3 & 27.2 & 16.3 & 15.9 & 10.2 & 0.184 \\
\hline 2 & 23 & 63 & 18.5 & 8.2 & 15.9 & 16.0 & 12.0 & 0.167 \\
\hline 3 & 14 & 50 & 17.7 & 9.7 & 15.4 & 15.5 & 11.1 & 0.152 \\
\hline 4 & 11 & 50 & 18.2 & 7.5 & 15.3 & 15.3 & 6.4 & 0.151 \\
\hline 5 & 3 & 46 & 17.8 & 6.2 & 15.3 & 15.4 & 13.5 & 0.150 \\
\hline$x$ & $x$ & 48 & 18.1 & 11.8 & 15.6 & 15.6 & 10.7 & 0.161 \\
\hline \multicolumn{9}{|l|}{ Lewotobi } \\
\hline 6 & 26 & 21 & 19.3 & 6.9 & 16.6 & 16.8 & 15.4 & 0.195 \\
\hline 7 & 25 & 67 & 18.8 & 8.1 & 16.5 & 16.6 & 12.8 & 0.183 \\
\hline 8 & 30 & 46 & 18.8 & 6.4 & 16.2 & 16.4 & 14.0 & 0.178 \\
\hline 9 & 32 & 33 & 19.0 & 6.6 & 15.8 & 15.9 & 10.8 & 0.171 \\
\hline 10 & 27 & 33 & 18.4 & 7.7 & 16.0 & 16.2 & 13.9 & 0.170 \\
\hline$x$ & $x$ & 40 & 18.9 & 7.1 & 16.2 & 16.4 & 13.4 & 0.179 \\
\hline \multicolumn{9}{|l|}{ piores } \\
\hline \multicolumn{9}{|l|}{ Egon } \\
\hline 1 & 13 & 42 & 17.1 & 9.0 & 13.9 & 14.2 & 19.4 & 0.124 \\
\hline 2 & 9 & 42 & 17.1 & 9.9 & 14.6 & 14.6 & 7.4 & 0.130 \\
\hline 3 & 1 & 38 & 17.3 & 9.2 & 14.6 & 14.7 & 8.8 & 0.133 \\
\hline 4 & 12 & 53 & 18.3 & 8.4 & 13.6 & 14.4 & 38.0 & 0.137 \\
\hline 5 & 2 & 21 & 17.7 & 7.0 & 14.7 & 14.8 & 11.0 & 0.137 \\
\hline$x$ & $x$ & 41 & 17.5 & 8.7 & 14.3 & 14.5 & 16.9 & 0.132 \\
\hline \multicolumn{9}{|l|}{ Lewotobi } \\
\hline 6 & 34 & 46 & 17.0 & 10.1 & 14.7 & 14.8 & 12.2 & 0.133 \\
\hline 7 & 31 & 42 & 17.9 & 9.9 & 14.7 & 14.8 & 10.1 & 0.139 \\
\hline 8 & 33 & 54 & 17.3 & 12.1 & 15.3 & 15.4 & 12.8 & 0.147 \\
\hline 9 & 29 & 50 & 17.9 & 6.0 & 15.4 & 15.5 & 11.2 & 0.152 \\
\hline 10 & 28 & 46 & 18.2 & 8.4 & 15.5 & 15.5 & 6.7 & 0.154 \\
\hline$x$ & $x$ & 48 & 17.6 & 9.3 & 15.1 & 15.2 & 10.6 & 0.145 \\
\hline
\end{tabular}


Tabela 19 - Classificação pelo teste REGWF das cinco melhores e cinco piores progênies por procedência, em volume médio por árvore, aos 5 anos de idade, para o exp1 (procedências da llha Flores: Egon e Lewotobi). E. urophylla, Anhembi-SP. melhores progênies 5 anos

\begin{tabular}{|c|c|c|c|c|c|c|c|c|c|}
\hline CLASS & PROGE & $\begin{array}{c}\text { FALHA } \\
\%\end{array}$ & $\begin{array}{l}\text { ALT } \\
(m)\end{array}$ & $\begin{array}{c}C V \\
A L T \\
\%\end{array}$ & DAP & DAPQ & $\begin{array}{c}\text { CV } \\
\text { DAP } \\
\%\end{array}$ & $\begin{array}{l}\text { VOL } \\
\text { real } \\
\text { m3/an }\end{array}$ & $\begin{array}{l}\text { VOL } \\
\text { real } \\
\text { m3/ha }\end{array}$ \\
\hline \multicolumn{10}{|l|}{ Egon } \\
\hline 1 & 22 & 38 & 21.4 & 7.4 & 17.7 & 17.8 & 10.3 & 0.239 & 249.2 \\
\hline 2 & 11 & 50 & 20.8 & 8.4 & 17.0 & 17.1 & 8.2 & 0.214 & 178.7 \\
\hline 3 & 3 & 46 & 20.7 & 8.0 & 16.8 & 17.0 & 15.1 & 0.214 & 193.6 \\
\hline 4 & 23 & 63 & 20.9 & 8.5 & 16.7 & 16.9 & 14.1 & 0.210 & 131.4 \\
\hline 5 & 14 & 50 & 19.8 & 4.6 & 17.1 & 17.2 & 12.5 & 0.207 & 172.5 \\
\hline$x$ & $x$ & 49 & 20.7 & 7.4 & 17.1 & 17.2 & 12.0 & 0.217 & 185.1 \\
\hline \multicolumn{10}{|l|}{ Lewoto } \\
\hline 6 & 25 & 67 & 21.3 & 10.4 & 17.9 & 18.0 & 15.2 & 0.248 & 138.0 \\
\hline 7 & 26 & 21 & 21.0 & 9.7 & 17.7 & 17.9 & 15.7 & 0.243 & 320.3 \\
\hline 8 & 30 & 46 & 20.3 & 8.0 & 17.8 & 17.9 & 14.0 & 0.233 & 210.6 \\
\hline 9 & 32 & 33 & 21.4 & 6.5 & 17.1 & 17.2 & 11.6 & 0.227 & 252.2 \\
\hline 10 & 27 & 33 & 20.9 & 5.6 & 17.0 & 17.2 & 14.9 & 0.220 & 244.7 \\
\hline$x$ & $x$ & 40 & 21.0 & 8.0 & 17.5 & 17.6 & 14.3 & 0.234 & 233.2 \\
\hline \multicolumn{10}{|l|}{ piores } \\
\hline \multicolumn{10}{|l|}{ Egon } \\
\hline 1 & 9 & 42 & 19.5 & 7.6 & 15.6 & 15.7 & 10.5 & 0.171 & 166.5 \\
\hline 2 & 1 & 38 & 19.3 & 8.0 & 15.9 & 16.0 & 9.3 & 0.174 & 181.2 \\
\hline 3 & 6 & 38 & 19.4 & 6.0 & 15.8 & 16.0 & 13.6 & 0.176 & 183.2 \\
\hline 4 & 4 & 38 & 19.3 & 6.8 & 15.9 & 16.0 & 12.3 & 0.177 & 184.4 \\
\hline 5 & 24 & 58 & 20.1 & 8.3 & 15.5 & 15.7 & 15.5 & 0.178 & 123.3 \\
\hline$x$ & $x$ & 43 & 19.5 & 7.3 & 15.8 & 15.9 & 12.2 & 0.175 & 167.7 \\
\hline \multicolumn{10}{|l|}{ Lewotob } \\
\hline 6 & 34 & 50 & 18.9 & 10.8 & 16.2 & 16.4 & 14.3 & 0.181 & 150.6 \\
\hline 7 & 31 & 42 & 20.4 & 9.5 & 16.1 & 16.2 & 12.0 & 0.191 & 185.6 \\
\hline 8 & 29 & 50 & 19.9 & 8.9 & 16.4 & 16.6 & 13.2 & 0.194 & 161.9 \\
\hline 9 & 28 & 46 & 20.3 & 9.0 & 16.6 & 16.7 & 7.7 & 0.201 & 181.7 \\
\hline 10 & 33 & 54 & 20.5 & 8.5 & 16.6 & 16.7 & 13.2 & 0.205 & 156.3 \\
\hline$x$ & $x$ & 48 & 20.0 & 9.3 & 16.4 & 16.5 & 12.1 & 0.194 & 167.2 \\
\hline
\end{tabular}


Na tabela 19 foi incluida mais uma coluna, extrapolando os dados individuais, onde se procurou calcular qual seria a média por hectare por progênie, apenas como ilustração, evidenciando a potencialidade de cada material.

A média das cinco progênies com maior volume por árvore, a maioria de Lewotobi, é superior a média do teste em $14,7 \%$ aos 3 anos, em $11,0 \%$ aos 4 anos e em $9,7 \%$ aos 5 anos de idade. Apesar da retirada de $50 \%$ em média das árvores de cada progênie, já no quinto ano as estimativas de volume por hectare superaram as obtidas no terceiro ano (pré desbaste), demonstrando o ótimo potencial de resposta do E. urophylla ao manejo para serraria ou para produção de sementes.

Em relação à procedência Egon, a média volumétrica indica aos 5 anos uma superioridade geral de $24,0 \%$ entre as 5 melhores e as 5 piores progênies, $(0,217 X$ $0,175 \mathrm{~m}^{3} / \mathrm{arv}$ ), demonstrando um bom potencial a ser explorado pelo melhoramento desde as populações selvagens, fruto da alta variabilidade natural. Mesmo uma seleção massal pode apresentar bons resultados, devido principalmente aos benefícios da recombinação, que potencializa o estoque genético em termos de possibilidades de cruzamentos, agora com amplas e iguais oportunidades de expressar mais equilibradamente as diferentes habilidades combinatórias dos individuos.

Os mesmos comentários são válidos para a procedência Lewotobi, que apresenta um diferencial volumétrico geral de 20,6\% entre as médias das 5 melhores e das 5 piores progênies $\left(0,234 \times 0,194 \mathrm{~m}^{3} /\right.$ arv $)$, revelando um potencial alto a ser explorado na seleção via massal ( fenotípica) ou genética ( por outros métodos que considerem o valor genético de cada progênie e do conjunto populacional, como as seleções sequencial ou a combinada), conforme será demonstrado à frente.

No anexo 1, são apresentadas as categorias silviculturais de classificação das árvores, demonstrando a normalidade das condições experimentais, que não apresentaram ocorrências anormais em relação aos padrões de qualidade obtidos para plantios de eucalipto na região.

Entre as duas procedências, a diferença entre as médias das 5 melhores e das 5 piores progênies mostrou a inferioridade da procedência Egon em 8\% para as 
melhores e $11 \%$ nas piores, frente à procedência Lewotobi, demonstrando uma proporção muito maior de progênies inferiores do que outras populações, apesar de contar com um número de progênies e árvores maior e, portanto, mais representativo.

Comparando a tabela $16 \mathrm{com}$ as tabelas 17 a 19 , a média das cinco progênies com maior volume por árvore é superior a média do teste em $22 \%$ aos 3 anos, em $10 \%$ aos 4 anos e em $17 \%$ aos 5 anos de idade. E apesar da retirada de quase $50 \%$ em média das árvores de cada progênie, já no quinto ano as estimativas de volume por árvore superaram as obtidas no terceiro ano (pré desbaste), demonstrando o ótimo potencial de resposta do E. urophylla ao manejo para serraria ou para produção de sementes. Isto indica que com o uso de $50 \%$ de desbaste. o volume por hectare deve crescer pelo menos $80 \%$ em apenas 3 anos (passando de 131 para $230 \mathrm{~m} 3$ / ha). A tabela 20 apresenta a distribuição das árvores nas classes de DAP aos 3 anos de idade, demonstrando a situação da população antes da interferência do desbaste, onde $13 \%$ das árvores eram superiores ou acima de 2 desvios padrão.

Tabela 20 - Distribuição de frequência de cada classe de DAP (cm), para o exp 1 (teste de procedências da Ilha Flores), 3 anos de idade. E. urophylla, Bofete-SP.

\begin{tabular}{lcccc}
\hline Classe & $\begin{array}{c}\text { Frequência } \\
\text { absoluta (árv's) }\end{array}$ & $\begin{array}{c}\text { Frequência } \\
\text { relativa simples } \\
(\%)\end{array}$ & $\begin{array}{c}\text { Frequência } \\
\text { absoluta } \\
\text { acumulada } \\
\text { (árv's) }\end{array}$ & $\begin{array}{c}\text { Frequência } \\
\text { relativa } \\
\text { acumulada (\%) }\end{array}$ \\
\hline Falha & 53 & 6,5 & 53 & 6,5 \\
Inferior & 314 & 38,5 & 367 & 45,0 \\
Média & 342 & 41,9 & 709 & 86,9 \\
Superior & 101 & 12,4 & 715 & 87,6 \\
Topo & 6 & 0,7 & 816 & 100,0 \\
\hline
\end{tabular}

onde, para o DAP

Inferior $=$ INFERIOR a média

Média = INTERMEDIÁRIA entre a média e a média +1 desvios padrão

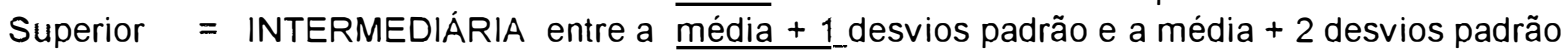

Topo = INTERMEDIÁRIA entre a média +2 desvios padrão e a média +3 desvios padrão 


\subsection{2 - ANÁLISE GENÉTICA}

Realizada com os dados aos 3 anos de idade, antes do desbaste (populações sem interferência). Os resultados da análise genética quantitativa das procedências Egon e Lewotobi, com os valores das estimativas dos componentes de variância, estão resumidos na tabela 21 , e as herdabilidades na tabela 22.

Tabela 21 - Estimativas dos componentes de variância, para o diâmetro (DAP), aos 3 anos de idade, para o exp 1 (procedências da llha Flores). E. urophylla. Bofete-SP.

\begin{tabular}{|c|c|c|c|c|c|c|}
\hline Procedência & $\sigma_{p}^{2}$ & $\sigma_{e}^{2}$ & $\sigma_{d}^{2}$ & $\sigma_{a}^{2}$ & $\sigma_{\mathrm{f}}^{2}$ & $\sigma_{\mathrm{fm}}^{2}$ \\
\hline Mt. Egon & 0.245 & -0.197 & 9.201 & 0.981 & 9.283 & 13.997 \\
\hline Mt. Lewotobi & 0.559 & -0.266 & 9.900 & 2.238 & 10.194 & 15.344 \\
\hline \multicolumn{3}{|c|}{$\begin{array}{l}\text { onde : } \\
\sigma_{p}^{2}=\text { variância genética entre progênies }\end{array}$} & \multicolumn{4}{|c|}{$\sigma_{a}^{2}=$ variância genética aditiva } \\
\hline \multicolumn{3}{|c|}{$\sigma_{e}^{2}=$ variância entre parcelas } & \multicolumn{4}{|c|}{$\sigma_{f}^{2}=$ variância fenotipica } \\
\hline \multicolumn{3}{|c|}{$\sigma_{d}^{2}=$ variância dentro de parcelas } & \multicolumn{4}{|c|}{$\sigma_{f m}^{2}=$ variância fenotipica média } \\
\hline
\end{tabular}

Tabela 22 - Estimativas de herdabilidades nos sentidos amplo $\left(h^{2} m\right)$ e restrito $\left(h^{2}\right.$; $h^{2} \mathrm{~d}$ ), para o diâmetro (DAP), 3 anos de idade, para o exp1. E. urophylla, Bofete-SP.

\begin{tabular}{lccc}
\hline Procedência & $h^{2} m$ & $h^{2} r$ & $h^{2} d$ \\
\hline Mt. Egon & 0.423 & 0.106 & 0.079 \\
Mt. Lewotobi & 0.618 & 0.219 & 0.169 \\
\hline
\end{tabular}

Os valores obtidos para as variâncias e herdabilidades indicam um bom aproveitamento dos diferenciais de seleção obtidos, com média influência da variabilidade transmitida via sexual ( aditiva ) na variância genética total (aditiva + dominante + epistática ). Assim, mudanças nos fatores ambientais influenciariam no 
fenótipo, especialmente na procedência Egon, que apresenta os menores valores para as herdabilidades, tanto no sentido amplo como no restrito.

Tabela 23 - Coeficientes de variação genética e fenotípica estimados, para a variável DAP, por procedência aos 3 anos de idade, no exp 1. E. urophylla. Bofete-SP.

\begin{tabular}{lcc}
\hline Procedência & CV genético & CV fenotípico \\
\hline Mt. Egon & 4,27 & 26,25 \\
Mt. Lewotobi & 6,23 & 26,61 \\
\hline
\end{tabular}

As tabelas 21,22 e 23 demonstram maiores valores das estimativas de variância genética e nas herdabilidades na procedência Mt. Lewotobi, que apresentou ainda a maior porcentagem de indivíduos superiores, com maior coeficiente de variação genético, igalando seu ceficiente de variação fenotípico a Egon.

Verificou-se valores baixos a médios para os erros associados, reflexo do número de progênies testado que pode ser considerado baixo, no caso da procedência Lewotobi, e do número considerado médio de plantas por parcela (progênie), que poderia gerar variações experimentais indesejáveis. Como consequência, a confiabilidade nas estimativas dos parâmetros genéticos e fenotípicos poderia sofrer algumas restrições, como é comum na literatura.

Por exemplo, Torggler (1987), ao analisar procedências e progênies de $E$. saligna, encontrou nas estimativas dos erros associados aos parâmetros genéticos e às herdabilidades valores negativos a baixos, deduzindo que isto é reflexo de problemas com amostragem deficiente nas populações, recomendando cautela na interpretação dos resultados. Também verificou herdabilidades dentro de procedências muito altas e não consistentes, por causa dos grandes desvios padrão com comportamento variável, sem tendências definidas com o avanço da idade. Os diferentes coeficientes de variação também não seguiram uma tendência comum com as idades para nenhum dos 3 locais e 8 procedências analisadas. 


\section{1. 3 Métodos de seleção}

Os três métodos de seleção testados - massal, sequencial e combinada - têm seus resultados comparados nas tabelas 24 ( Egon ) e 25 ( Lewotobi).

Tabela 24 - Estimativas dos parâmetros genéticos para cada método de seleção simulado, para diâmetro DAP (cm), na procedência Egon, 3 anos de idade, para o $\exp 1$. Média da população $=11,59 \mathrm{~cm}$. E. urophylla, Bofete-SP.

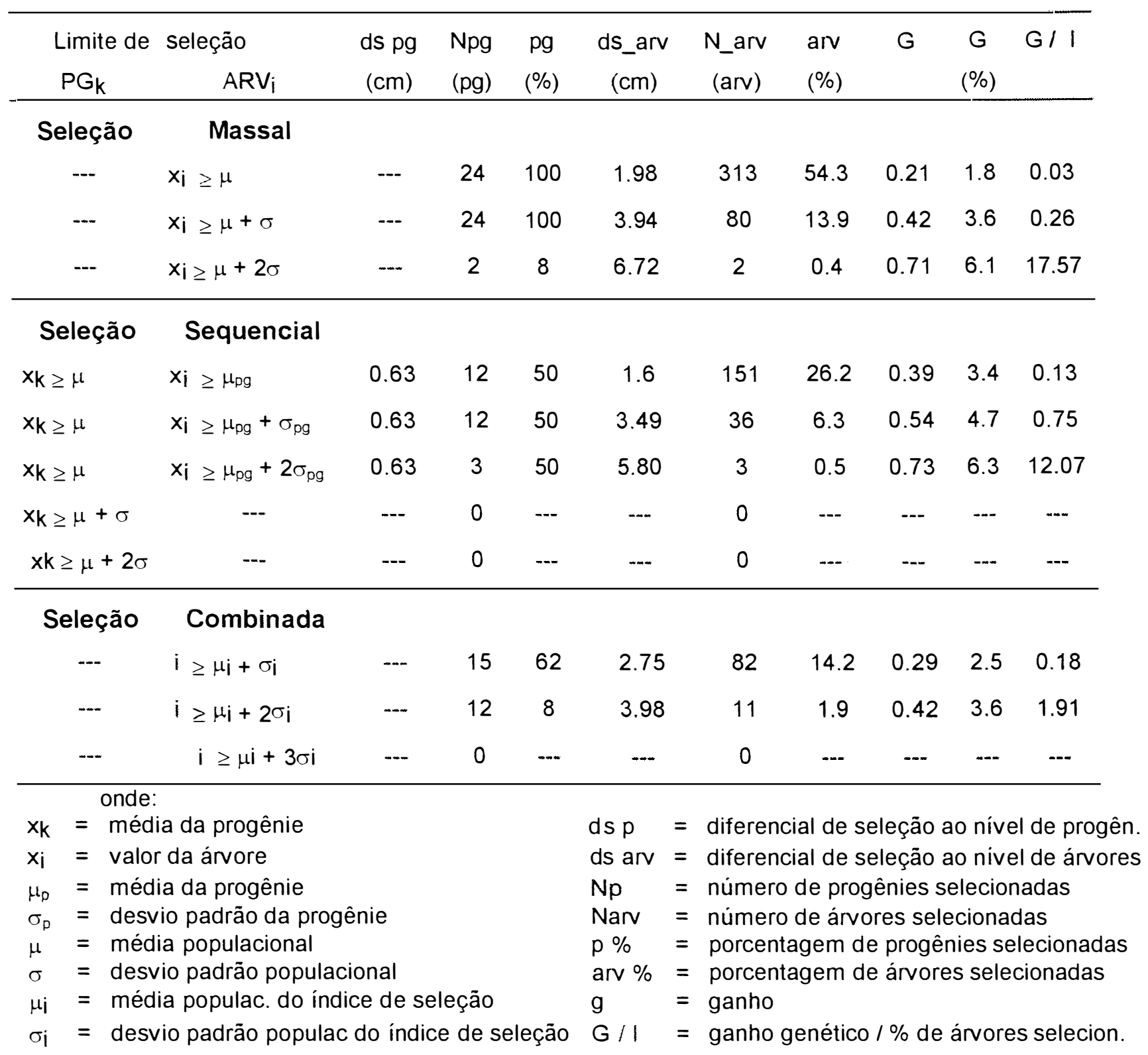


Tabela 25 - Estimativas de parâmetros genéticos para os métodos de seleção simulados, para diâmetro (DAP, em cm) aos 3 anos de idade, procedência Lewotobi. E. urophylla, Bofete-SP.

Média da população $=12,0 \mathrm{~cm}$

\begin{tabular}{|c|c|c|c|c|c|c|c|c|c|c|}
\hline $\begin{array}{l}\text { Limite de } \\
P G_{k}\end{array}$ & $\begin{array}{l}\text { seleção } \\
\text { ARV }\end{array}$ & $\begin{array}{l}\text { ds pg } \\
(\mathrm{cm})\end{array}$ & $\begin{array}{l}\text { Npg } \\
(p g)\end{array}$ & $\begin{array}{r}\mathrm{pg} \\
(\%) \\
\end{array}$ & $\begin{array}{l}\text { ds_arv } \\
(\mathrm{cm})\end{array}$ & $\begin{array}{l}\text { N_an } \\
\text { (an) }\end{array}$ & $\begin{array}{l}\text { arv } \\
(\%)\end{array}$ & G & $\begin{array}{l}G \\
(\%)\end{array}$ & $G / 1$ \\
\hline Seleção & Massal & & & & & & & & & \\
\hline$\cdots$ & $x_{i} \geq \mu$ & $\cdots$ & 10 & 100 & 2.34 & 130 & 54 & 0.51 & 4.3 & 0.08 \\
\hline$\cdots$ & $x_{i} \geq \mu+\sigma$ & $-\cdots$ & 9 & 90 & 4.65 & 29 & 12 & 1.02 & 8.5 & 0.71 \\
\hline-- & $x_{i} \geq \mu+2 \sigma$ & -.- & 1 & 10 & 8.69 & 1 & 0.4 & 1.91 & 15.9 & 37.85 \\
\hline$x k \geq \mu$ & $x_{i} \geq \mu_{\mathrm{og}}$ & 1.14 & 3 & 30 & 1.96 & 42 & 19 & 1.04 & 8.7 & 0.46 \\
\hline$x_{k} \geq \mu$ & $x_{i} \geq \mu_{p g}+\sigma_{p g}$ & 1.14 & 3 & 30 & 4.53 & 8 & 3 & 1.47 & 12.3 & 3.50 \\
\hline
\end{tabular}

Seleção Sequencial

\begin{tabular}{|c|c|c|c|c|c|c|c|c|c|c|}
\hline$x k \geq \mu$ & $x_{i} \geq \mu_{p g}+2 \sigma_{p g}$ & 1.14 & 1 & 10 & 7.44 & 1 & 0.4 & 1.96 & 16.4 & 36.41 \\
\hline$x k \geq \mu+\sigma$ & $\cdots$ & $\cdots$ & 0 & -- & $\cdots$ & $\cdots$ & $-\cdots$ & 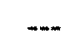 & -- & $\cdots \cdots$ \\
\hline$x_{k} \geq \mu+2 \sigma$ & --- & --- & 0 & $-\cdots$ & -- & $-\cdots$ & --- & $-\cdots$ & -- & -- \\
\hline
\end{tabular}

\section{Seleção Combinada}

$\begin{array}{rlrrrrrrrrr}-- & i \geq \mu i+\sigma i & -- & 6 & 60 & 3.36 & 35 & 14 & 0.74 & 6.1 & 1.01 \\ --- & i \geq \mu i+2 \sigma i & --- & 1 & 10 & 5.14 & 7 & 3 & 1.13 & 9.4 & 7.74 \\ -- & i \geq \mu i+3 \sigma i & --- & 1 & 10 & 8.69 & 1 & 0.4 & 1.91 & 15.9 & 91.57\end{array}$

\begin{tabular}{|c|c|c|c|}
\hline & onde: & & \\
\hline$x_{k}$ & $=$ média da progênie & ds $p$ & diferencial de seleção ao nível de progên. \\
\hline$x_{i}$ & $=$ valor da árvore & ds arv & diferencial de seleção ao nivel de árvores \\
\hline$\mu_{p}$ & $=$ média da progênie & $\mathrm{Np}$ & $=$ número de progênies selecionadas \\
\hline$\sigma_{\mathrm{p}}$ & $=$ desvio padrão da progênie & Narv & $=$ número de árvores selecionadas \\
\hline$\mu$ & $=$ média populacional & $p \%$ & $=$ porcentagem de progênies selecionadas \\
\hline$\sigma$ & $=$ desvio padrão populacional & $\operatorname{arv} \%$ & $=$ porcentagem de árvores selecionadas \\
\hline$\mu \mathrm{i}$ & $=$ média populac. do índice de seleção & G & $=$ ganho \\
\hline$\sigma_{\mathrm{i}}$ & $\begin{array}{l}=\text { desvio padrão populac. do índice de } \\
\text { seleção }\end{array}$ & $G / 1$ & $=$ ganho genético $/ \%$ de árvores selecion. \\
\hline
\end{tabular}


Comparando os três métodos testados nas duas procedências ( tabelas 24 e

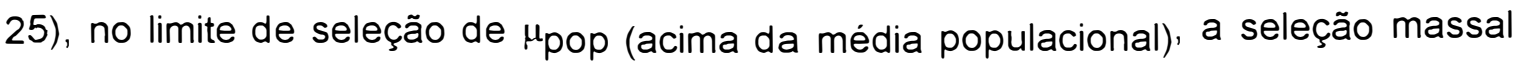
obteve melhores resultados, com a melhor relação $G$ / I e uma base genética mais ampla.

A seleção sequencial obteve melhores ganhos porcentuais, mas a menor base genética, recomendando eliminar $90 \%$ das progênies, o que do ponto de vista da população é absurdo. Já a seleção combinada resultou tanto em baixo ganho porcentual como em uma base genética reduzida, pois exigiria remover mais de $80 \%$ das familias, o que da mesma forma é um exagero que desequilibraria toda a população e traria grandes inconvenientes à polinização, acabando por favorecer a autofecundação e consequentemente, mais prejuizos do que ganhos.

Este aspecto vital para as estratégias do melhoramento é discutido por Torggler (1987), quanto às limitações práticas de aplicar as recomendações teóricas sobre os testes de procedência/ progênie em delineamentos de blocos compactos. Citando Nanson (1972) e Wright (1978), a autora ressalta o inconveniente do espaçamento irregular após o desbaste, bem como o desbalanço entre a contribuição diferencial das familias e do número de árvores por familia, sendo este o maior defeito deste tipo de delineamento.

Dessa forma, Torggler (1987) recomenda que para aproveitar os testes de progênie dentro de procedências, deve-se selecionar em um ciclo e na geração seguinte, em novo teste de progênie, então aplicar maiores intensidades de seleção entre e dentro das familias.

Ao nivel da média da população + um desvio padrão ( $\mu p o p+\sigma p o p)$, a seleção sequencial foi a que teve melhores ganhos porcentuais com maior base genética, seguida pela seleção massal. Ao nivel de $\mu$ pop mais três opop, não foram selecionadas familias nem individuos, por não ocorrerem árvores nesta categoria.

Em função dos altos niveis de seleção ( porcentagem de árvores a eliminar) necessários para atingir maiores ganhos genéticos, optou-se por recomendar uma estratégia em duas etapas: 
- numa primeira fase, eliminação de metade das árvores inferiores; aguardar 2 ou 3 anos para uma coleta de sementes com recombinação, para manutenção de maior base genética. Neste caso, os testes funcionariam como uma população base com médio nivel de seleção.

- na segunda fase, realizar novo desbaste, eliminando mais árvores inferiores na classe $\mu p o p+\sigma p o p$ (média da população + um desvio padrão), até atingir um máximo de $80 \%$ dos individuos, para não incorrer em problemas de polinização deficiente ou preferencial. Isto poderia acontecer sob desbastes severos, que acabam resultando em má distribuição espacial das árvores e ao final prejudicam na obtenção dos ganhos teóricos previstos, e ainda aumentam a endogamia.

Os valores das estimativas dos parâmetros genéticos e fenotipicos presentes nas tabelas 21 a 25 são compativeis com os dados existentes na literatura já citada, para a mesma região de experimentação.

Volume por progênie antes e após desbaste seletivo

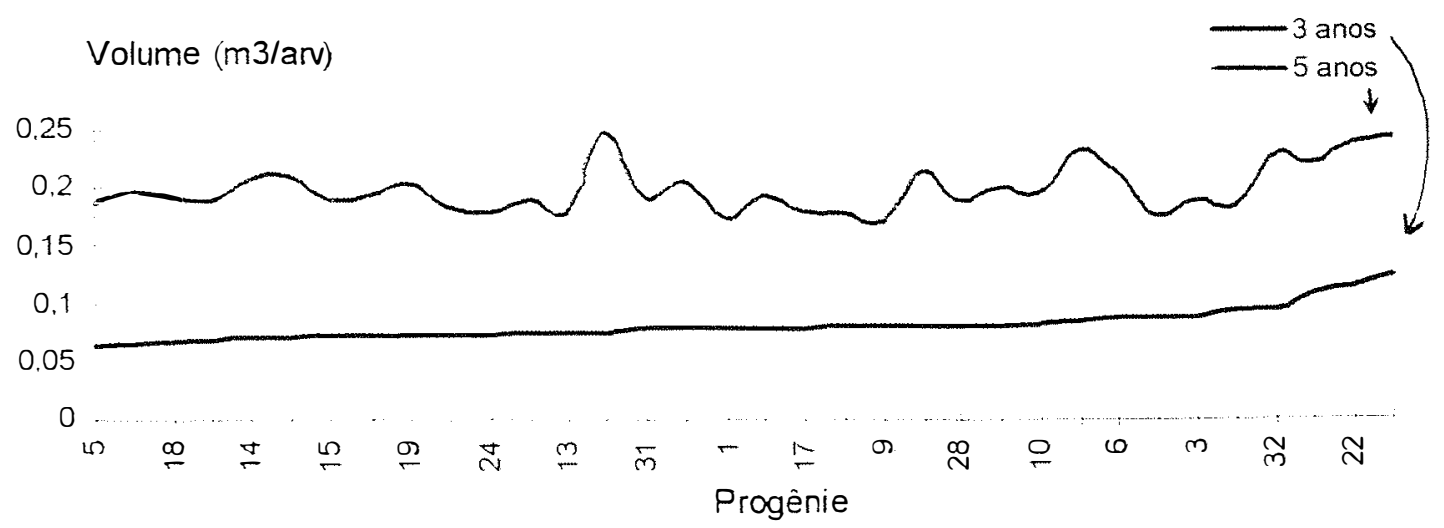

Figura 5: Gráfico de volume das progênies da procedência llha Flores (exp 1), evidenciando as respostas diferenciadas 2 anos após desbaste. E. urophylla, Bofete-SP. 


\subsection{4 - Seleção de Ideotipos}

Dentro do objetivo de caracterizar adequadamente a grande variabilidade fenotípica da população natural, foram identificados e quantificados os ideotipos, separando-os em 3 categorias definidas pelo tipo de casca. Aos 3 anos, definiu-se somente 2 tipos de casca : fibrosa e lisa. Porém, aos 5 anos de idade, com o maior desenvolvimento das árvores e a maior expressão das caracteristicas morfológicas, revelou-se necessária nova classificação dos tipos de casca, que passaram a ser 3 : fibrosa, rugosa e lisa. A descrição da casca concentrou-se nas árvores superiores, que são as de interesse para o melhoramento, e que permanecerão após os desbastes.

A avaliação de outras características morfológicas foi tentada, mas não pôde ser concluida, apesar da coleta de material (só houve frutificação em parte das árvores superiores, e a coleta em árvores novas revelou-se muito trabalhosa e por vezes inútil, escalando árvores sem frutos).

E diante da imensa variação natural para tipos de folha e de fruto, não apresentando correlação clara com o ideotipo, conforme pode ser conferido no anexo 4 , decidiu-se avaliar somente o tipo de casca, que é o parâmetro mais visivel, de mais fácil identificação e com menor variação. Os resultados estão nas tabelas $26 e 27$ (aos 3 anos de idade) e 28 (aos 5 anos).

Tabela 26 - Frequência e crescimento das árvores classificadas por ideotipo, entre as 107 árvores superiores aos 3 anos de idade, para o exp 1. E. urophylla, Bofete-SP.

\begin{tabular}{lcccc}
\hline \multicolumn{1}{c}{ Ideotipo } & $\begin{array}{c}\text { Frequência } \\
(\%)\end{array}$ & $\begin{array}{c}\text { Altura } \\
\text { média }(\mathrm{m})\end{array}$ & $\begin{array}{c}\text { DAP } \\
\text { médio }(\mathrm{cm})\end{array}$ & $\begin{array}{c}\text { Volume } \\
\left(\mathrm{m}^{3} / \mathrm{arv}\right)\end{array}$ \\
\hline casca fibrosa & 77,6 & 17,31 & 15,95 & 0,157 \\
casca lisa & 22,4 & 16,36 & 15,51 & 0,139 \\
\hline
\end{tabular}


Os ideotipos acima podem ser definidos pelas fotografias das figuras 4 e 5 , e nas descrições do item 3. 2. 6 sobre metodologia de avaliação dos ideotipos apresentada.

Relacionando o crescimento em altura, diâmetro (DAP) e volume com a tipicidade das árvores superiores (tabela 26), há uma tendência geral das árvores superiores com casca lisa possuirem menor crescimento, ou seja, menos

Tabela 27 - Tipicidade dos individuos superiores de cada procedência e no experimento, aos 3 anos de idade, para o exp 1 :

\begin{tabular}{|c|c|c|c|c|c|c|c|c|c|c|}
\hline \multirow[t]{3}{*}{ Procedência } & \multirow{3}{*}{$\begin{array}{l}\mathrm{N}^{\circ} \mathrm{de} \\
\text { árvores }\end{array}$} & \multicolumn{3}{|c|}{ Superiores } & \multirow{2}{*}{\multicolumn{2}{|c|}{$\begin{array}{l}\% \text { na pro } \\
\text { fibrosa }\end{array}$}} & \multirow{2}{*}{\multicolumn{2}{|c|}{$\begin{array}{r}\text { cedência } \\
\text { lisa }\end{array}$}} & \multirow{3}{*}{$\begin{array}{r}\% \text { nas árv } \\
\text { supe } \\
\text { fibrosa }\end{array}$} & \multirow{3}{*}{$\begin{array}{l}\text { ores } \\
\text { riores } \\
\text { lisa }\end{array}$} \\
\hline & & \multirow[b]{2}{*}{$N^{\circ}$} & \multirow[b]{2}{*}{ e } & \multirow[b]{2}{*}{$(\%)$} & & & & & & \\
\hline & & & & & $N^{0}$ & e $(\%)$ & $N^{\circ} e$ & $(\%)$ & & \\
\hline Egon & 558 & 71 & & 12,7 & 57 & 10,2 & 14 & 2,5 & 80,3 & 19,7 \\
\hline Lewotobi & 226 & 36 & & 15,9 & 26 & 11,5 & 10 & 4,4 & 72,2 & 27,8 \\
\hline Experimento & & & & & & & & & & \\
\hline (Ilha Flores) & 784 & 107 & & 13,6 & 84 & 10,7 & 24 & 2,9 & 78,6 & 22,4 \\
\hline
\end{tabular}

Quanto aos totais de árvores, a procedência Lewotobi apesar de possuir $29 \%$ do total de árvores do experimento, tem 33,6 \% das árvores superiores. Lewotobi também possui uma frequência bem maior do ideotipo casca lisa, ou $76 \%$ a mais do que Egon, isto é, 4,4\% contra 2,5\%. Isto parece coerente com as informações de Martin e Cossalter (1976), que encontraram muitas árvores com a parte superior do tronco ( $1 / 3$ ) com casca lisa em Lewotobi, cuja população de $E$. urophylla também aparentava menor idade mas com maior porte do que em Egon. Tanto estes autores como Vieira e Bucsan (1977) comentam sobre a presença do E. alba nestes locais, inclusive associado no subosque ou na borda das florestas, o que sugeriu a possibilidade de introgressão entre as duas espécies, ou mesmo hibridação.

Outra observação é que aos 3 anos de idade, as árvores estão muito jovens, ainda em inicio de diferenciação da deiscência da casca. A época do ano também 
interfere na classificação, sendo as diferenças mais evidentes no pico da estação de crescimento ( no verão, em janeiro/ fevereiro). Na estação seca, com o crescimento mínimo e o envelhecimento da casca, pode haver dificuldade de distinguir os ideotipos, em especial árvores intermediárias. Para reavaliar os ideotipos quanto à idade, aos 5 anos já está mais bem definida a tipificação, pelo que foi considerada mais precisa esta última classificação, apresentada na tabela 28.

Tabela 28 - Tipos de casca em árvores superiores de E. urophylla e seus parâmetros dendrométricos. Experimento 1, Bofete - SP, aos 5 anos, janeiro de 1996.

\begin{tabular}{|c|c|c|c|c|c|c|c|c|}
\hline TIPO & $\mathrm{N}$ & $\begin{array}{l}N \\
\%\end{array}$ & $\begin{array}{l}\text { DAP } \\
(\mathrm{cm})\end{array}$ & $\begin{array}{c}\text { CV } \\
\text { DAP } \\
\% \\
\end{array}$ & $\begin{array}{l}\text { ALT } \\
(\mathrm{m})\end{array}$ & $\begin{array}{c}\text { CV } \\
A L T \\
\% \\
\end{array}$ & $\begin{array}{l}\text { VOL } \\
\text { m3/ arv }\end{array}$ & $\begin{array}{l}\mathrm{CV} \\
\mathrm{VOL}\end{array}$ \\
\hline \multicolumn{9}{|l|}{ EGON } \\
\hline 1 - FIBROSA & 193 & 64 & 16,45 * & 13.00 & 20,11 * & 7.59 & 0,197 & 30.52 \\
\hline 2 - RUGOSA & 96 & 31 & 16,16 & 11.21 & 19,94 & 7.65 & 0,188 & 27.66 \\
\hline 3 - LISA & 15 & 5 & 14,68 & 13.13 & 19,10 & 10.00 & 0,150 & 31.00 \\
\hline total & 304 & média: & 16,27 & & 20,01 & & 0,192 & \\
\hline \multicolumn{9}{|l|}{ LEWOTOBI } \\
\hline 1 - FIBROSA & 92 * & 68 & 16,97 * & 13.15 & 20,67 & 8.85 & 0,217 * & 32.96 \\
\hline 2 - RUGOSA & 37 & 28 & 16,97 & 14.45 & 20,15 & 9.49 & 0,213 & 35.20 \\
\hline 3 - LISA & 5 & 4 & 16,43 & 15.89 & $21,47^{\star}$ & 3.66 & 0,204 & 34.63 \\
\hline total & 134 & média: & 16,95 & & 20,52 & & 0,215 & \\
\hline
\end{tabular}

Obs: cascas: fibrosa = escura e indeiscente; rugosa = pardo-clara textura mais fina e granular, persistente na base e deiscente na parte média do tronco; lisa = creme-clara, deiscência total.

A tabela 28 demonstra que o ideotipo de casca lisa é ligeiramente inferior aos outros, exceto para altura na procedência Lewotobi. A proporção dos ideotipos 
também não variou significativamente entre as duas procedências, que se mostraram com dados dendrométricos e porcentuais muito próximos nesta nova classificação.

Isto contradiz o conhecimento aparente normalmente divulgado sobre a superioridade das árvores de casca lisa, pois existem árvores tão grandes ou maiores com outros tipos de casca. Aparentemente, como a frequência desse ideotipo casca lisa é baixa, as poucas árvores lisas e claras destacam-se e chamam mais a atenção dentro de uma população onde predominam as árvores de casca escura ou parda (mais de $90 \%$, sendo ao redor de $60 \%$ fibrosa escura e $30 \%$ rugosa parda). A categoria rugosa apresenta uma variação na parte baixa do tronco, que pode apresentar casca rugosa da base até 40 a $70 \%$ da altura, possuindo a partir daí casca lisa no alto.

A tendência é que com maior idade possa ser alterada a classificação apresentada, principalmente considerando algumas árvores do ideotipo de casca rugosa como sendo lisa ou fibrosa. Como as características morfológicas da casca tendem a se acentuar com a maturidade, espera-se ser possivel inclusive dividir em categorias por porcentagem de casca, como já foi feito para $E$. saligna de acordo com Santos \& Scanavacca (1992) e Baez (1994), para a população de Itatinga-SP.

Uma ressalva que pode ser feita é quanto à amostragem do material, que pode ser considerada ainda insuficiente para expressar a proporção real dos ideotipos na população. Estima-se que avaliando acima de 600 árvores para cada procedência se poderia chegar a valores dendrométricos ainda mais próximos, com menor amplitude de variação em função do aumento da amostra, pois a tendência observada é a convergência dos valores dos ideotipos para a média da população.

Isto indica que, em termos de volume de madeira, não haveria grande vantagem de selecionar as árvores mais comuns da espécie ( o padrão dominante, ou seja, casca fibrosa) ou as do padrão minoritário (neste caso, o ideotipo de casca lisa), ou ainda trabalhar com a população como um todo, principalmente em idades jovens, conforme ressaltado por Luz et al., 1996. Pode-se deduzir que a característica casca ainda estaria em segregação na população, parecendo incorporada mas não apresentando correlação definida com os dados dendrométricos. Em mais algumas 
gerações de recombinação esta situação deverá se definir, quando a seleção por ideotipos poderia se tornar mais eficiente.

Com base nestes resultados, conclui-se que o ideotipo de casca lisa deve ser melhor estudado, inclusive avaliando a eficiência de uma seleção dirigida, para caracterizar seu comportamento dendrométrico e genético.

Por isso decidiu-se incluir neste estudo o experimento n. 2, onde progênies oriundas de matrizes selecionadas para o ideotipo casca lisa ( chamado $E$. "platyphylla" apenas como divulgação, conforme Ferreira, $1996^{1}$ ) são comparadas, procurando comprovar a possivel eficácia de uma coleta seletiva direcionada para aumento da frequência do ideotipo de casca lisa clará. Os resultados estão apresentados no ítem 4.2 , a seguir.

\footnotetext{
${ }^{1}$ FERREIRA, M. Departamento de Ciências Florestais, ESALQ / USP. Comunicação pessoal, 1996.
} 


\section{2 - ANÁLISE DA POPULAÇÃO RECOMBINADA ( $\exp .2$ )}

\subsection{1 - COMPORTAMENTO SILVICULTURAL}

- progênies, antes e após o desbaste

Da mesma forma que para o exp1, a análise é feita antes da realização de um desbaste (avaliando todas as árvores) e após o mesmo. Antes, com a população completa, foi possivel estimar os parâmetros genéticos em condições normais. A comparação entre os resultados anteriores e posteriores permite avaliar os efeitos causados pelos desbastes seletivos sobre os parâmetros dendrométricos.

A tabela 29 resume os principais resultados da análise de variância, facilitando as comparações entre as 3 idades. Na sequência, são apresentadas as tabelas completas para cada idade.

Tabela 29 - Níveis de probabilidade do Teste F para ANAVA - análises de médias de $\operatorname{DAP}(\mathrm{cm})$ e de volume por árvore ( $\mathrm{m} 3 /$ arv ), aos 4,5 e 6 anos. E. urophylla, Anhembi-SP.

\begin{tabular}{lcclllll}
\hline ldade & \multicolumn{2}{c}{4 anos } & 5 anos & 6 anos \\
\hline Fonte de & G.L. & DAP & Volume /arv & DAP & Volume/ arv & DAP & Volum/ arv \\
Variação & & & & & & & \\
\hline Progênie & 55 & $0.0001^{\star \star}$ & $0.0001^{\star \star}$ & $0.0009^{* \star}$ & $0.0011^{\star \star}$ & $0.0011^{\star \star}$ & $0.0014^{\star \star}$ \\
Bloco & 3 & $0.0237^{*}$ & $0.0014^{\star \star}$ & $0.0024^{* \star}$ & $0.0828 n s$ & $0.0017^{\star \star}$ & $0.0093^{\star \star}$ \\
\hline
\end{tabular}

Foram verificadas diferenças estatísticas altamente significativas entre progênies, para DAP ( aos 4, 5 e 6 anos ) e para volume por árvore (aos 4 e 6 anos). Entre blocos também houve diferença estatística significativa, para DAP nas 3 idades e para volume por árvore aos 4 e 6 anos. Para altura, as diferenças foram altamente significativas nas 3 idades, e estão demonstradas nas tabelas 30 a 32 . 
As tabelas 30 (antes do desbaste), 31 e 32 (depois do desbaste ) apresentam os resultados completos da análise de variância para o experimento 2 .

Tabela 30 : Análise de variância de diâmetro (DAP), altura e volume aos 4 anos, para o exp2 (população recombinada - Outras Ilhas). E.urophylla , Anhembi - SP.

DAP : $m=12,82 \mathrm{~cm}$

\begin{tabular}{cccccc}
\hline FV & GL & QM & F & Prob>F & CV exp \% \\
\hline 56 prog. & 33 & 4,430 & $2,18^{\star *}$ & 0,0001 & 11,12 \\
4 blocos & 3 & 7,043 & $3,47^{\star}$ & 0,0175 & \\
Resíd 56 p & 165 & 2,029 & & & \\
\hline
\end{tabular}

$H: m=18,13 m$

$\mathrm{H}$ transform. $=2768,75$

\begin{tabular}{cccccc}
\hline FV & GL & QM $/ 10^{5}$ & $F$ & Prob>F & CV exp \% \\
\hline 56 prog. & 33 & 7,070 & $2,07^{\star \star}$ & 0,0002 & 21,13 \\
4 blocos & 3 & 48,550 & $14,18^{\star \star}$ & 0,0001 & \\
Resíd 56 p & 165 & 3,423 & & & \\
\hline
\end{tabular}

VOL: $m=0,127 \mathrm{~m}^{3} /$ ha $\quad$ Vol transform. $=0,4831$

\begin{tabular}{cccccc}
\hline FV & GL & QM & F & Prob>F & CV exp \% \\
56 prog. & 33 & 0,003530 & $2,24^{\star \star}$ & 0,0001 & 28,22 \\
4 blocos & 3 & 0,008568 & $5,43^{\star \star}$ & 0,0014 & \\
Resíd 56 p & 165 & 0,001578 & & & \\
\hline
\end{tabular}


Tabela 31 : Análise de variância de diâmetro (DAP), altura e volume aos 5 anos, para o exp2 (população recombinada - Outras Ilhas). E.urophylla, Anhembi - SP.

DAP : $m=16,50 \mathrm{~cm}$

\begin{tabular}{|c|c|c|c|c|c|}
\hline $\mathrm{FV}$ & $G L$ & QM & $\mathrm{F}$ & Prob $>F$ & $C V \exp \%$ \\
\hline 56 prog. & 55 & 10,154 & $1,75^{\star \star}$ & 0,0009 & 14,61 \\
\hline 4 blocos & 3 & 28,122 & $4,83^{\star \star}$ & 0,0024 & \\
\hline bloc $\times$ prog & 165 & 8,511 & 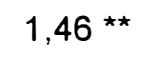 & 0,0005 & \\
\hline Resid $56 p$ & 730 & & & & \\
\hline \multicolumn{6}{|c|}{$H: \quad m=18,13 m$} \\
\hline $\mathrm{FV}$ & GL & $\mathrm{QM} / 10^{5}$ & $\mathrm{~F}$ & Prob $>F$ & $C V \exp \%$ \\
\hline 56 prog. & 33 & 7,070 & $2,07^{\star \star}$ & 0,0002 & 21,13 \\
\hline 4 blocos & 3 & 48,550 & $14,18^{\star \star}$ & 0,0001 & \\
\hline Resid $56 \mathrm{p}$ & 165 & 3,423 & & & \\
\hline \multicolumn{6}{|c|}{ VOL : $m=0,223 \mathrm{~m}^{3} / \mathrm{ha}$} \\
\hline FV & GL & QM & $\mathrm{F}$ & Prob $>F$ & $C V \exp \%$ \\
\hline 56 prog. & 55 & 0,010483 & $1,73^{\star \star}$ & 0,0011 & 35,70 \\
\hline 4 blocos & 3 & 0,013540 & 2,24 & 0,0828 & \\
\hline bloc $\times$ prog & 165 & 0,008530 & $1,41^{\star \star}$ & 0,0017 & \\
\hline Resid $56 \mathrm{p}$ & 730 & 0,006057 & & & \\
\hline
\end{tabular}


Tabela 32 : Análise de variância de diâmetro (DAP), altura e volume aos 6 anos, para o exp2 ( população recombinada - Outras lihas). E.urophylla , Anhembi - SP.

DAP : $m=17,53 \mathrm{~cm}$

\begin{tabular}{cccccc}
\hline FV & GL & QM & F & Prob>F & CV exp \% \\
\hline 56 prog. & 55 & 12,464 & $1,74 * \star$ & 0,0011 & 15,28 \\
4 blocos & 3 & 36,443 & $5,09 \star \star$ & 0,0017 & \\
bloc x prog & 165 & 10,766 & $1,50 \star \star$ & 0,0003 & \\
Resid 56 p & 672 & 7,165 & & & \\
\hline
\end{tabular}

$H: m=18,13 m \quad H$ transform. $=2768,75$

\begin{tabular}{cccccc}
\hline FV & GL & QM $/ 10^{5}$ & $F$ & Prob>F & CV exp \% \\
\hline 56 prog. & 33 & 7,070 & $2,07^{\star \star}$ & 0,0002 & 21,13 \\
4 blocos & 3 & 48,550 & $14,18^{\star \star}$ & 0,0001 & \\
Resid 56 p & 165 & 3,423 & & & \\
\hline VOL : $\mathrm{m}=0,278 \mathrm{~m}^{3} / \mathrm{ha}$ & & $(\mathrm{H}=24,41 \mathrm{~m})$ \\
\hline FV & $\mathrm{GL}$ & $\mathrm{QM}$ & $\mathrm{F}$ & Prob>F & CV exp \% \\
56 prog. & 55 & 0,018252 & $1,72^{\star \star}$ & 0,0014 & 37.44 \\
4 blocos & 3 & 0,041127 & $3,87^{\star \star}$ & 0,0093 & \\
bloc x prog & 165 & 0,015219 & $1,43^{\star \star}$ & 0,0012 & \\
Resid $56 \mathrm{p}$ & 672 & 0,010638 & & & \\
\hline
\end{tabular}

a) Antes do desbaste, aos 4 anos de idade, a tabela 30 mostra as diferenças altamente significativas ( ${ }^{\star *}$ ) a $1 \%$ de probabilidade entre as progênies, para todas as caracteristicas: diâmetro - DAP , altura e volume real por árvore.

b) Depois do desbaste, as tabelas 31 e 32 mostram as diferenças significativas em dois niveis ( ${ }^{*}$ a $5 \% e^{\star \star}$ a $1 \%$ de probabilidade ) entre as progênies, para as caracteristicas conforme a seguir. 
Aos 5 anos de idade ( 1 ano após o desbaste, tabela 31 ), houve diferença altamente significativa ( ${ }^{\star \star}$ ) entre as progênies, para diâmetro - DAP, altura e volume real por árvore. Houve também diferença altamente significativa ( ** ) para a interação bloco X progênie, mostrando a influência diferencial do desbaste entre os tratamentos ( reações distintas entre as progênies ).

Aos 6 anos de idade ( 2 anos após o desbaste, tabela 32 ): manteve-se a diferença altamente significativa $\left({ }^{\star \star}\right)$ entre as progênies, para diâmetro - DAP, altura e volume real por árvore. Houve também diferença altamente significativa ( ${ }^{*}$ ) para a interação bloco $X$ progênie, mostrando a influência diferencial do desbaste entre os tratamentos.

Comparando as 2 idades após o desbaste, nota-se que com o passar do tempo há uma tendência geral de queda da influência diferencial do desbaste ( que causou a eliminação da competição ) sobre as árvores remanescentes, pois as significâncias vão se reduzindo, e os valores das probabilidades aumentam.

A procedência originária da recombinação de "Outras llhas ", que sempre apresenta as maiores médias de crescimento, pode ser considerada superior às do exp.1 pela análise de variância, que mostra após o desbaste, ou seja, a partir dos 5 anos, diferenças altamente significativas ao nivel de progênies, para médias de altura, DAP e volume real estimado por árvore.

Após o desbaste, esperava-se não ocorrer diferenças significativas entre as médias das progênies, ou que fossem muito pequenas, devido ao efeito uniformizador do desbaste. Mas em apenas 1 ano já recomeça uma estratificação entre as progênies, principalmente em altura.

Da mesma forma que ocorreu com o exp1, só que de uma forma muito mais acentuada neste caso, existem progênies que mantém a mesma taxa de crescimento normal ( como as de $n^{0} 58$ e 14 ) e outras que se destacam por serem mais responsivas à redução da competição ( $n^{0 S} 47$ e 2 ). Isto pode ser chamado de efeito diferencial do desbaste, ou reação diferencial das progênies, indicando interação genótipo $X$ ambiente, por abertura do espaçamento. 
Como o desbaste próximo de $50 \%$ não foi sistemático, mas seletivo, a duplicação da área por planta ( subindo de $6 \mathrm{~m}^{2}$ para, em média, $12 \mathrm{~m}^{2} / \mathrm{arv}$ ) também variou. Espacialmente, essa área por árvore é irregular devido à localização casual das árvores superiores, causando assim pontos de competição mais intensa ou mais leve dentro do teste, o que pode também influenciar nos efeitos ambientais e nas respostas das árvores, além da reação da progênie, conforme o gráfico abaixo (Fig.6).

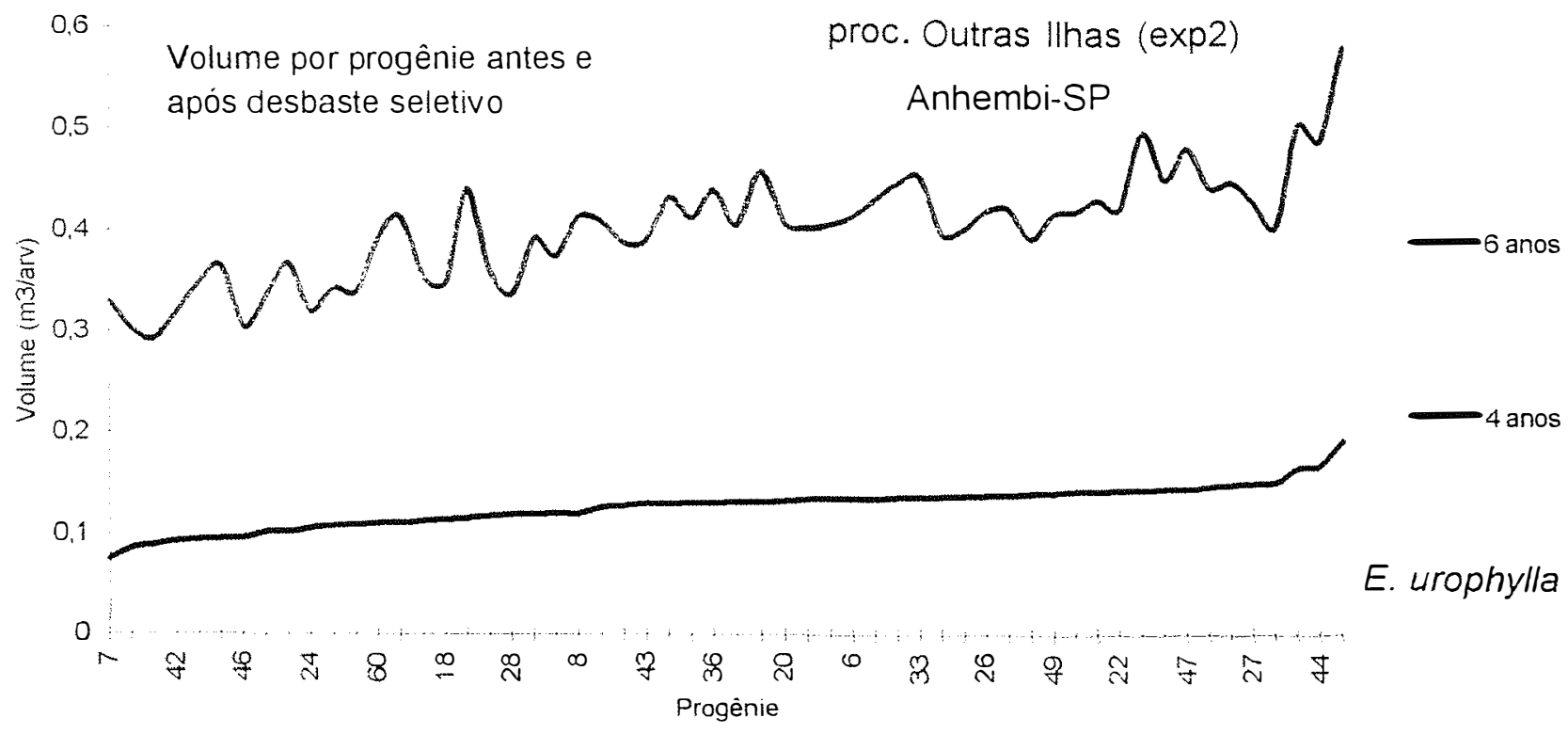

Algumas progênies se destacam com potencial de crescimento muito acima das demais ( progs 58 e 44 ) ou muito abaixo ( progs 41, 4 e 7 ). Ver lista completa da classificação das progênies por DAP e volume pelo teste REGWF no anexo 2 . Os valores de CV experimental aumentaram bastante após o desbaste, mas se estabilizaram rapidamente, com pequena tendência de acréscimo. As médias de crescimento em DAP e altura correspondem ao citado em literatura (Pinto Jr, 1984; Mori et al., 1988 ) para a região de Anhembi-SP, com crescimento um pouco maior para este teste, conforme Luz et al., 1996. Para a idade mais jovem, ou antes da interferência do desbaste, todas as caracteristicas analisadas mostraram diferenças altamente significativas.

Os resultados dendrométricos para as 3 idades do exp. 2 estão resumidos na tabela 33, onde também foram incluidos os dados de crescimento aos 3 anos de idade, porém estes só foram usados para os cálculos de médias gerais nesta tabela. Não puderam ser aproveitados nas análises subsequentes, pois houve problemas de mistura de dados de várias parcelas quando da coleta de dados no campo. 
Tabela 33 : Estatísticas descritivas, exp1. E. urophylla, Anhembi-SP.

\begin{tabular}{|c|c|c|c|c|c|c|c|c|}
\hline Idade & $\begin{array}{l}\mathrm{N}^{0} \mathrm{de} \\
\text { árvores }\end{array}$ & $\begin{array}{c}\text { Falhas } \\
\text { +desbast } \\
(\%)\end{array}$ & $\begin{array}{l}\text { Altura } \\
\text { média } \\
(\mathrm{m})\end{array}$ & $\begin{array}{l}\text { DAP } \\
\text { médio } \\
(\mathrm{cm})\end{array}$ & $\begin{array}{c}\text { Volume } \\
\text { real } \\
\left(\mathrm{m}^{3} / \mathrm{arv}\right)\end{array}$ & $\begin{array}{l}\text { Volume } \\
\text { real } \\
\left(\mathrm{m}^{3} / \mathrm{ha}\right)\end{array}$ & $\begin{array}{l}\text { CV } \\
\text { Altura } \\
(\%)\end{array}$ & $\begin{array}{l}\text { CV } \\
\text { DAP } \\
(\%)\end{array}$ \\
\hline & Antes & do & desbaste & & & & & \\
\hline 3 & 1.662 & 7 & 16,7 & 12,3 & 0,091 & 141,8 & 26,8 & 24,7 \\
\hline \multirow[t]{2}{*}{4} & 1.654 & 8 & 18.1 & 12.8 & 0.127 & 196.1 & 31.5 & 24.3 \\
\hline & Após & 0 & desbaste & & & & & \\
\hline 5 & 954 & 47 & 22.3 & 16.5 & 0.223 & 197.9 & 15.7 & 7.7 \\
\hline 6 & 881 & 51 & 24.4 & 17.5 & 0.278 & 227.7 & 16.5 & 8.0 \\
\hline
\end{tabular}

Entre os 3 e 4 anos de idade, houve um acréscimo de $37 \%$ no volume real médio por árvore. Foi, então, feito o desbaste de $39 \%$, que somado às falhas iniciais resultou numa redução final de $47 \%$ do número de árvores.

Em apenas um ano após, ou seja, aos 5 anos, esse volume cresceu mais $78 \%$, mostrando a grande capacidade de resposta do material recombinado, como resultante de ganhos na taxa de crescimento de $21 \%$ para altura e $19 \%$ para DAP.

Da mesma forma que já discutido para o experimento 1 , esse não é só um ganho real das árvores, mas incorpora o resultado matamático das médias antes e após eliminar as árvores inferiores e dominadas. Se fossem comparados somente os dados das remanescentes, antes e depois do desbaste, o ganho real em volume seria inferior a $35 \%$.

Em dois anos após o desbaste, o aumento no volume foi de $24 \%$, com o DAP crescendo somente mais $6 \%$ e a altura mais $9 \%$, o que comprova que a taxa real de crescimento em resposta ao desbaste, para as árvores superiores remanescentes (acima da média da população), seria em torno de 25 a $30 \%$ no primeiro ano e 15 a $20 \%$ no segundo. Isso levaria a um decréscimo no IMA, de $18 \%$ em 1 ano e $4 \%$ em dois anos, indicando que o terceiro ano após o desbaste, ou no máximo $\circ 4^{\circ}$ ano, seria o momento apropriado para uma nova intervenção complementar. 
Apenas para facilitar as comparações, a tabela 34 apresenta as médias das cinco melhores e das cinco piores progênies, classificadas pelo volume por árvore ; obviamente, os estudos completos consideraram toda a população (ver anexos 1 e 2).

Tabela 34 : Estimativas das médias das cinco melhores e das cinco piores progênies, classificadas em volume por árvore. E. urophylla, Anhembi-SP.

\begin{tabular}{ccccccccc}
\hline Classif & $\begin{array}{c}\text { Idade } \\
\text { Falha } \\
(\%)\end{array}$ & $\begin{array}{c}\text { Altura } \\
\mathrm{m}\end{array}$ & $\begin{array}{c}\mathrm{CV} \\
\text { altura } \\
(\%)\end{array}$ & $\begin{array}{c}\text { DAP } \\
\mathrm{cm}\end{array}$ & $\begin{array}{c}\mathrm{CV} \\
\mathrm{DAP} \\
(\%)\end{array}$ & $\begin{array}{c}\text { Volume } \\
\text { real } \\
\mathrm{m}^{3} / \mathrm{arv}\end{array}$ & $\begin{array}{c}\text { Volume } \\
\text { real } \\
\mathrm{m}^{3} / \mathrm{ha}\end{array}$ \\
\hline \multirow{2}{*}{ Melhores } & 5 & 11 & 19.3 & 19.4 & 14.5 & 27.0 & 0.166 & 246.7 \\
& 5 & 48 & 22.9 & 7.2 & 18.2 & 14.4 & 0.276 & 243.0 \\
\hline 5 & 4 & 11 & 16.1 & 30.9 & 10.8 & 37.0 & 0.087 & 131.1 \\
Piores & 5 & 56 & 21.5 & 8.5 & 15.0 & 14.9 & 0.177 & 129.1 \\
& 6 & 59 & 23.2 & 9.4 & 15.8 & 14.7 & 0.212 & 146.2 \\
\hline
\end{tabular}

A média das cinco progênies com maior volume por árvore é superior a média do teste em $30,7 \%$ aos 4 anos, em 23,8 \% aos 5 anos e em 25,2 \% aos 6 anos de idade. Apesar da retirada de $50 \%$ em média das árvores de cada progênie, já no sexto ano as estimativas de volume por hectare superaram as obtidas no quarto ano (pré desbaste), demonstrando o ótimo potencial de resposta do E. urophylla ao manejo para serraria ou para produção de sementes. Isto também indicou que os parâmetros genéticos deveriam ser acompanhados.

As diferenças observadas são muito altas, chegando a $125 \%$ entre as médias das 5 melhores e das 5 piores progênies, seguindo o mesmo padrão analisado anteriormente para o exp1. O ritmo de crescimento em volume real por árvore chega a $66 \%$ logo após o desbaste, mas este ritmo se reduz para níveis mais baixos entre o $5^{\circ}$ e $\circ 6^{\circ}$ ano, revelando claramente que a competição voltou a ocorrer. Esses saltos no desenvolvimento devem influenciar as estimativas de análises estatísticas frente às idades, especialmente nos componentes ambientais das variâncias fenotípicas. 


\section{2.2 - ANÁLISE GENÉTICA ( EXP. 2 ):}

Analisando as estimativas dos componentes de variância e das herdabilidades (tabelas 35 e 36 ), observa-se que as variâncias diminuiram após o desbaste, mas aos 6 anos aumentaram grandemente em valores absolutos, apesar de variarem bem menos na sua proporção ( \% ).

Tabela 35 - Estimativas dos componentes de variância para volume por árvore (m3/arv) e suas porcentagens, aos 4, 5 e 6 anos de idade. E. urophylla, Anhembi-SP.

\begin{tabular}{cccccccccc}
\hline Desbaste & Idade & $\sigma_{p}^{2}$ & $\%$ & $\sigma^{2}{ }_{e}$ & $\%$ & $\sigma_{d}^{2}$ & $\%$ & $\sigma_{b}^{2}$ & $\%$ \\
\hline Sem & 4 & 121.68 & 3.6 & 0.00 & 0.0 & 3240.28 & 95.4 & 35.51 & 1.0 \\
Com & 5 & 90.71 & 2.7 & 295.16 & 8.7 & 2996.06 & 87.9 & 23.33 & 0.7 \\
Com & 6 & 184.97 & 3.0 & 600.44 & 9.8 & 5258.75 & 85.7 & 91.04 & 1.5
\end{tabular}

$$
\begin{array}{ll}
\text { onde : } \sigma^{2}=\text { variâncias : } & \sigma_{p}^{2}=\text { var. genética entre progênies; } \\
\sigma^{2}{ }_{e}=\text { var. entre parcelas } & \sigma_{d}^{2}=\text { variància dentro de parcelas; } \quad \sigma^{2} \text { = variância entre blocos; }
\end{array}
$$
continuação...

$\begin{array}{llll}\text { Desbaste Idade } & \sigma^{2} a & \sigma^{2}{ }_{f} & \sigma^{2}{ }_{m}\end{array}$

\begin{tabular}{lllll} 
Sem & 4 & 486.73 & 3361.96 & 222.94 \\
Com & 5 & 362.84 & 3381.93 & 258.13 \\
Com & 6 & 739.88 & 6044.16 & 499.41 \\
\hline
\end{tabular}

$$
\sigma_{\mathrm{f}}^{2}=\text { var. fenotipica } \quad \sigma_{\mathrm{fm}}^{2}=\text { var. fenotípica média }
$$

Estes dados comparativos antes e após o desbaste são muito interessantes por serem dificilmente encontrados na literatura, tanto nacional como internacional, 
especialmente para eucaliptos. Há exemplos para coniferas (Gwaze, 1996) e apenas comentários sem dados dos efeitos genéticos do desbaste, para E. pellita e Acacia (Hanwood, 1996).

Os seguintes fatos ocorreram aos 5 anos: a) redução da diferença da média das cinco progênies com maior volume por árvore ; b) não-significância para volume por árvore; c) redução nas estimativas absolutas das variâncias. São conseqüências do efeito uniformizador do desbaste seletivo realizado aos 4 anos. Aos 6 anos já pode ser observada uma nova estratificação entre as árvores, que reverte a tendência dessas estimativas citadas e provoca o aumento dos valores.

Nota-se que as estimativas absolutas dos componentes de variância estão mais sujeitas ao efeito do desbaste seletivo do que a proporção entre as mesmas, indicando pequena influência sobre a estimativa das herdabilidades, que tende a diminuir com o tempo, como observado na tabela 36 .

Tabela 36 - Estimativas de herdabilidades nos sentidos amplo $\left(h^{2} m\right)$ e restrito $\left(h^{2} i\right.$ e $h^{2} d$ ), para volume por árvore, antes e depois do desbaste seletivo. E. urophylla, Anhembi-SP.

\begin{tabular}{ccccc}
\hline Desbaste & Idade (anos) & $\mathrm{h}^{2} \mathrm{~m}$ & $\mathrm{~h}^{2} \mathrm{i}$ & $\mathrm{h}^{2} \mathrm{~d}$ \\
\hline antes & 4 & 0.546 & 0.145 & 0.113 \\
depois & 5 & 0.351 & 0.107 & 0.091 \\
depois & 6 & 0.370 & 0.122 & 0.106 \\
\hline
\end{tabular}

Deve-se observar que a redução na estimativa da herdabilidade média foi maior, pois este desbaste manteve todas as progênies ( não houve desbaste entre), selecionando árvores apenas dentro de cada progênie. 


\subsection{3 - SELEÇÃO DE GENÓTIPOS}

\subsubsection{Escolha do Método de Seleção}

Foram comparados três métodos de seleção: massal, sequencial e combinada, conforme demonstrado na tabela 37, procurando escolher ao final o que proporcionasse maior ganho, mas mantendo uma base genética aceitável.

Tabela 37 - Estimativas dos parâmetros genéticos para cada método de seleção, avaliados numericamente para volume por árvore, aos 4 anos de idade. E. urophylla, Anhembi-SP.

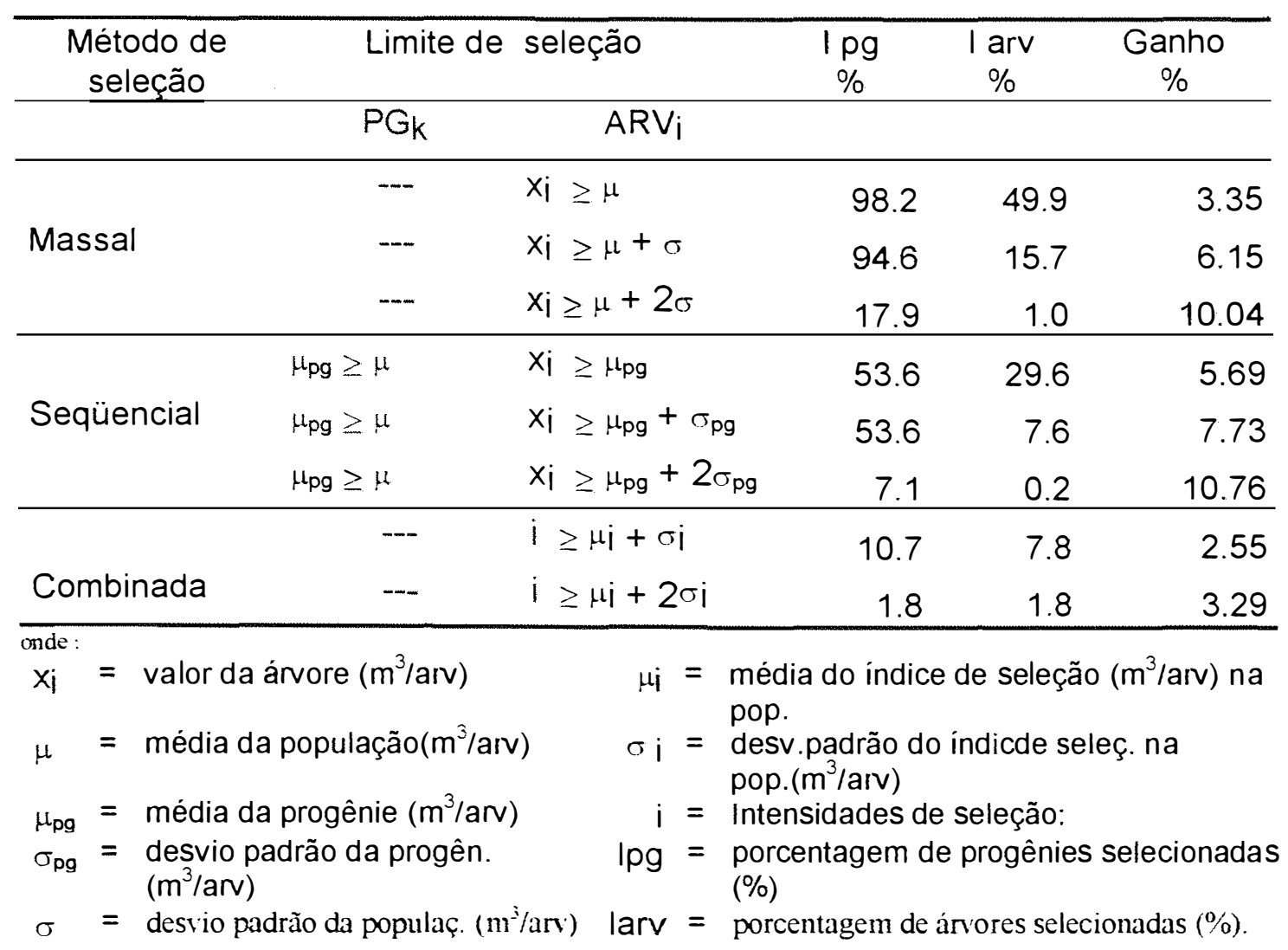

O método de seleção massal foi o que proporcionou maior ganho genético com menor intensidade de seleção (tabela ${ }^{37}$. Assim é mantida uma base genética maior, desejável nesta fase da seleção ( ainda não se completou a recombinação, faltando 
estabilizar mais os fenótipos ainda numa próxima geração, quando será aplicável seleção mais intensa ). Implicações destes aspectos são discutidas por Cotterill (1986) e por White, (1992).

A seleção seqüencial, apesar de fornecer resultados semelhantes aos da seleção massal, não foi escolhida por usar maiores intensidades de seleção, perdendo mais genótipos.

Para a seleção de árvores superiores neste teste, numa primeira fase foram desbastadas em média as $50 \%$ piores árvores em volume por progênie, não sendo eliminada nenhuma progênie, visando minimizar as perdas de base genética e a contribuição potencial desses genótipos recombinados. O ganho genético predito acima foi de $3,4 \%$; porém, dados de plantios operacionais na região indicam que na 1a geração após uma recombinação e seleção, este ganho pode ser bem maior (mais de $8 \%$ ), comparando com a população base. A literatura também apresenta resultados superiores a $10 \%$ nestes casos, para E. urophylla (Nirsatmanto, 1996), exemplificando que numa segunda etapa, com mais um desbaste, este ganho poderá ser mais elevado. 


\section{2. 3. 2 Seleção de Ideotipos}

Os ideotipos foram definidos pelos mesmos padrões de casca adotados para o experimento 1 ( ver fotografias das figuras 4 e 5 e descrições do ítem 3.2.6 sobre metodologia de avaliação dos ideotipos). Conforme a tabela 38 , as árvores superiores aos 4 anos foram separadas por ideotipos, comparando-as com a população toda.

Tabela 38 - Frequência e crescimento das árvores classificadas por ideotipo, entre 261 árvores superiores aos 4 anos de idade, para o exp 2. E. urophylla, Anhembi-SP.

\begin{tabular}{lccccc}
\hline \multicolumn{1}{c}{ Ideotipo } & $\begin{array}{c}\text { No de } \\
\text { árvores }\end{array}$ & $\begin{array}{c}\text { Frequência } \\
(\%)\end{array}$ & $\begin{array}{c}\text { Altura } \\
\text { média }(\mathrm{m})\end{array}$ & $\begin{array}{c}\text { DAP } \\
\text { médio }(\mathrm{cm})\end{array}$ & $\begin{array}{c}\text { Volume } \\
\left(\mathrm{m}^{3} / \mathrm{arv}\right)\end{array}$ \\
\hline $\begin{array}{l}\text { a) árv. Superiores: } \\
\text { casca lisa }\end{array}$ & 73 & 27,8 & 21,4 & 17,3 & 0,239 \\
$\quad$ casca fibrosa & 188 & 72,2 & 20,9 & 16,4 & 0,214 \\
\hline b) população toda & 1.654 & - & 18,1 & 12,8 & 0,127 \\
\hline
\end{tabular}

Aos 4 anos de idade, as árvores superiores do ideotipo casca lisa eram apenas $4,4 \%$ da população, mas representavam $28 \%$ das árvores superiores. Apresentaram maior altura e maior diâmetro - DAP do que o outro ideotipo, o mesmo ocorrendo em relação às médias da população. Em volume por árvore, o ideotipo casca lisa foi $12 \%$ superior ao ideotipo com casca fibrosa, e apresentou $88 \%$ acima da média da população completa antes do desbaste.

Como a expressão do tipo de casca se acentua com a idade, foi feita uma reavaliação dos ideotipos aos 6 anos de idade. Com árvores mais velhas foi possivel estabelecer 3 ideotipos, que foram casca lisa, rugosa e fibrosa, sempre de acordo com a descrição inicial. 
Nesta nova classificação, apresentada nas tabelas 39 e 40, observou-se redução da frequência do ideotipo de casca fibrosa, do qual muitas árvores passaram a ser consideradas como rugosas, grupo que acaba englobando características intermediárias entre os outros ideotipos.

Tabela 39 - Avaliação de ideotipos das árvores superiores da população recombinada multiprocedências (Outras Ilhas), aos 6 anos de idade. E. urophylla, Bofete-SP.

\begin{tabular}{|c|c|c|c|c|c|c|c|c|c|c|}
\hline \multirow[t]{2}{*}{$\begin{array}{c}\text { Classe das } \\
\text { árvores }\end{array}$} & \multirow[t]{2}{*}{$\begin{array}{l}\mathrm{N}^{\circ} \text { de } \\
\text { árvores }\end{array}$} & \multicolumn{3}{|c|}{$\%$ dos } & \multicolumn{5}{|c|}{ ideotipos (casca) } & \multirow[b]{2}{*}{$(\%)$} \\
\hline & & $\mathrm{N}^{\circ}$ & e & (\%) & $\mathrm{N}^{\circ}$ & e & $(\%)$ & $\mathrm{N}^{\circ}$ & e & \\
\hline Superiores & 143 & 92 & & 64,3 & 41 & & 28.6 & 10 & & 7,0 \\
\hline $\begin{array}{c}\text { População } \\
\text { toda }\end{array}$ & 881 & 576 & & 65,4 & 244 & & 27.7 & 61 & & 6,9 \\
\hline
\end{tabular}

Esta nova classificação demonstra um certo equlibrio entre as frequências dos ideotipos nas árvores superiores e na população toda. $\mathrm{Na} 1^{\mathrm{a}}$ classificação aos 4 anos, o ideotipo casca lisa apresentou maior frequência entre as superiores, o que foi mudado após o desbaste, que eliminou mais árvores inferiores entre o ideotipo casca fibrosa, praticamente igualando essas proporções entre superiores e a população desbastada.

A comparação entre ideotipos aos 6 anos é detalhada na tabela 40, que apresenta os dados dendrométricos e a superioridade relativa dos ideotipos para as 143 árvores superiores nessa idade. O grupo de árvores com casca lisa apresentou superioridade de $78 \%$ sobre a população desbastada, enquanto as com casca rugosa apresentaram-se com mais $66 \%$ e as com casca fibrosa $58 \%$, o que resultou numa média de + $58 \%$ das árvores superiores sobre a média da população. Aparentemente, nesta idade o tipo de casca começa a mostrar correlação com a 
produtividade, pois a porcentagem de casca na parte alta do tronco decresce de forma semelhante com altura, DAP e volume, conforme mostra a tabela 40.

Tabela 40 - Ideotipos para casca aos 6 anos e seus parâmetros dendrométricos, em 143 árvores superiores de E. urophylla. Experimento 2, Anhembi - SP, fev/ 1996.

\begin{tabular}{ccccccc}
\hline TIPO & N & $\begin{array}{c}\text { N } \\
\%\end{array}$ & $\begin{array}{c}\text { DAP } \\
(\mathrm{cm})\end{array}$ & $\begin{array}{c}\text { ALT } \\
(\mathrm{m})\end{array}$ & $\begin{array}{c}\text { VOL } \\
\mathrm{m3/} \text { arv }\end{array}$ & $\begin{array}{c}\text { Superioridade em } \\
\text { relação à população, } \\
\text { para volume }\end{array}$ \\
\hline 1 - LISA & 10 & 7 & 23,08 & $\mathbf{2 6 , 1 6}$ & $\mathbf{0 , 4 9 5}$ & $+178 \%$ \\
2 - RUGOSA & 41 & 28,6 & 22,15 & 26,39 & 0,462 & $+166 \%$ \\
3 - FIBROSA & 92 & 64,3 & 21,41 & 26,15 & 0,428 & $+154 \%$ \\
\hline só superiores & 143 & 16 & 21,73 & 26,24 & 0,441 & $+158 \%$ \\
\hline total população & 881 & média & 16,27 & 20,01 & 0,192 & $100 \%$ \\
\hline
\end{tabular}

Nesta avaliação, as árvores do ideotipo casca rugosa apresentaram a partir da metade do tronco, até o ápice, casca lisa com deiscência em placas/ lamelas. E as do ideotipo casca fibrosa, exibiram casca lisa somente na extremidade do tronco e nos ramos, com acúmulo de casca fibrosa aumentando gradativamente até a base.

A conclusão é que sempre ocorre alguma porcentagem de casca lisa a partir da copa e dos ramos, em qualquer árvore de E. urophylla, sendo uma característica da espécie. Porém, essa porcentagem aumenta em certas árvores até chegar à base do tronco, quando se define o ideotipo casca lisa típico, que ocorre ao redor de $7 \%$ da população.

Esta mesmo tipo de classificação foi feita por Martin e Cossalter ( 1975 ) na llha Flores, no Monte Mandiri ( um vulcão semelhante aos Montes Egon e Lewotobi - ver apêndice ). Encontraram um aumento na ocorrência de árvores com casca lisa à medida que desciam a encosta ; a $1000 \mathrm{~m}$ de altitude, $75 \%$ das árvores possuiam só casca fibrosa e só 5 \% tinham parte da casca lisa ; a $800 \mathrm{~m}$ já havia 25 \% de árvores 
com casca lisa, e a $450 \mathrm{~m}$ de altitude $100 \%$ das árvores apresentaram casca lisa com somente 1 a $1,5 \mathrm{~m}$ de casca rugosa na base do tronco.

Os resultados obtidos para este experimento sugerem que a proporção do ideotipo de casca lisa deverá se alterar pouco, pois já estão visualmente bem definidas, mantendo ao redor de 7 a $8 \%$ das árvores, e o ideotipo intermediário, de casca rugosa, poderá sofrer alguma alteração aumentando ligeiramente sua frequência, em função das diferenças entre os tipos de casca irem se acentuando com a idade.

As árvores com casca lisa, portanto, apresentaram maiores incrementos, o que difere dos resultados do experimento 1 e também do obtido por Chaperon (1976), apresentado no Quadro 1 (pg 23) , que apresentou como inferior à média populacional o crescimento deste material. Esse autor considerou este tipo de árvore como "E. platyphylla", ou um híbrido natural com E. alba , que ocorre em todos os locais de origem das populações testadas; isto é sugerido para muitas espécies arbóreas por Anderson (1968).

O passo seguinte neste estudo é a comparação entre os resultados dos dois experimentos, visando avaliar a possível eficácia de uma coleta seletiva direcionada para aumento da frequência do ideotipo de casca lisa clara. Os resultados estão a seguir.

Conforme discutido por Matheson (1988), citando ainda Booth et al. (1988), em uma mesma região ecológica pode-se comparar dados experimentais pois as parcelas dos tratamentos necessariamente não precisam ser contíguas. Segundo o autor, divisões políticas municipais ou estaduais não são critérios válidos para testes biológicos, mas sim a similaridade dos sítios onde os materiais são testados, sendo mais importante o clima e depois o tipo de solo. No caso das comparações dos dois experimentos, considerou-se que estão na mesma região ecológica, separados por poucos quilômetros, no mesmo microclima, havendo grande semelhança dos solos muito arenosos sob a mesma vegetação original. 


\section{3 ESTRATÉGIA DE MELHORAMENTO DAS POPULAÇÕES}

\subsubsection{COMPARAÇÃO SILVICULTURAL}

A comparação entre o desenvolvimento dos materiais genéticos dos dois experimentos procurou evidenciar as vantagens adaptativas da recombinação no seu estágio inicial ( $1^{\mathrm{a}}$ geração ), conforme a tabela 41 .

Tabela 41: Estatísticas básicas (descritivas) para os 2 experimentos com E. urophylla Exp 1, Bofete - SP , populações selvagens de Flores (Egon e Lewotobi):

\begin{tabular}{|c|c|c|c|c|c|c|c|c|}
\hline Idade & $\begin{array}{l}\text { No de } \\
\text { arvor. }\end{array}$ & $\begin{array}{c}\text { Falhas } \\
+ \text { desb. } \\
\%\end{array}$ & $\begin{array}{l}\text { Altura } \\
\text { (m) }\end{array}$ & $\begin{array}{l}\text { DAP } \\
(\mathrm{cm})\end{array}$ & $\begin{array}{c}\text { Volume } \\
\text { real } \\
\text { (mªr) }\end{array}$ & $\begin{array}{c}\text { Volume } \\
\text { real } \\
\left(\mathrm{m}^{3} / \mathrm{ha}\right)\end{array}$ & $\begin{array}{c}\text { CV } \\
\text { Altura } \\
(\%)\end{array}$ & $\begin{array}{c}\text { CV } \\
\text { DAP } \\
(\%)\end{array}$ \\
\hline 3 & 764 & 6 & 14.5 & 11.7 & 0.081 & 126.5 & 21.1 & 26.9 \\
\hline 4 & 444 & 46 & 17.9 & 15.2 & 0.150 & 136.4 & 9.6 & 13.2 \\
\hline 5 & 439 & 46 & 20.2 & 16.5 & 0.199 & 178.7 & 8.3 & 13.1 \\
\hline \multicolumn{9}{|c|}{ Exp 2 , Anhembi - SP, população melhorada F1 de Outras Ilhas } \\
\hline 3 & 1.662 & 7 & 16,7 & 12,3 & 0,091 & 141,8 & 26,8 & 24,7 \\
\hline 4 & 1.654 & 8 & 18.1 & 12.8 & 0.127 & 196.1 & 31.5 & 24.3 \\
\hline 5 & 954 & 47 & 22.3 & 16.5 & 0.223 & 197.9 & 15.7 & 7.7 \\
\hline 6 & 881 & 51 & 24.4 & 17.5 & 0.278 & 227.7 & 16.5 & 8.0 \\
\hline
\end{tabular}

A população melhorada do exp2, nas mesmas idades (aos 3 , 4 e 5 anos) apresentou $12 \%$ a mais de volume real por árvore, sobre a média da população selvagem da Ilha Flores. Entre as procedências, Outras Ilhas superou Egon em 17 \%, mas apresentou apenas $3 \%$ a mais que Lewotobi. Aos 5 anos, essas diferenças foram de $16 \%$ sobre Egon e menos de $4 \%$ sobre Lewotobi. 
Para a região de Anhembi, que é a mesma dos experimentos 1 e 2, os valores de DAP e altura obtidos por Pinto Jr. (1984), já citado na tabela 4, mostraram-se um pouco menores ( - $12 \%$ em altura e - $14 \%$ em DAP ) para a procedência Lewotobi, que no exp1 atingiu crescimento maior do que em Aracruz, no litoral do Espírito Santo, região de floresta pluvial de alta produtividade. O mesmo ocorreu comparando com os dados do exp2, só que com vantagens ainda maiores, com a população recombinada de Outras Ihas superando os melhores resultados dendrométricos da tabela 4 em mais $26 \%$ em altura e $17 \%$ em DAP.

Isto também poderia indicar que os indices de desenvolvimento foram bastante homogêneos na região ecológica única que engloba os dois experimentos, testados em condições edafoclimáticas e topográficas similares, não havendo restrições conforme exposto por Matheson (1988).

Comparando as populações selvagens do exp1, com a recombinada do exp2, deduz-se que a simples seleção massal direcionada para a coleta das matrizes de casca lisa ( sementes que originaram o exp2 ) alterou bastante o perfil populacional quanto à distribuição de freqûencia de indivíduos por classe. Devem ser considerados ainda os efeitos positivos esperados com a continuidade do processo de recombinação para a próxima geração.

Os coeficientes de variação na população recombinada, tanto para altura como para DAP, revelaram-se um pouco maiores nas populações selvagens antes do desbaste, indicando maior variabilidade natural nas condições de origem.

Após o desbaste, a população recombinada e selecionada para casca lisa apresentou uma variação muito maior na altura, sobre maiores valores absolutos de médias, o que indica ser muito mais responsiva à melhoria das condições de sítio (ambientais ), enquanto que para o DAP, os coeficientes de variação se mostraram muito próximos. 


\subsection{2 - COMPARAÇÃO GENÉTICA}

A avaliação conjunta dos parâmetros genéticos permite inferir os componentes de variância que se mostram mais influenciados por idade, população e pela seleção de ideotipos. Os dados obtidos, porém, não são diretamente comparáveis, pois algumas condições experimentais são diferentes, principalmente delineamentos e efeitos ambientais. Algumas tendências podem ser compatíveis, auxiliando a compreender a magnitude e as tendências desses parâmetros na tabela 42.

Tabela 42: Variâncias e herdabilidades com base no diâmetro (DAP) para populações de E. urophylla.

Exp 1, Bofete - SP : Procedência Egon

\begin{tabular}{|c|c|c|c|c|c|c|c|c|c|}
\hline Idade & $\begin{array}{l}\text { CV } \\
\text { Altura } \\
(\%)\end{array}$ & $\begin{array}{l}\text { CV } \\
\text { DAP } \\
(\%)\end{array}$ & $\begin{array}{l}\text { Vari } \\
\text { Progên }\end{array}$ & $\begin{array}{l}\text { ân ci a } \\
\text { Dentro }\end{array}$ & $\begin{array}{l}\text { s } G \text { e } n \\
\text { Aditiva }\end{array}$ & $\begin{array}{l}\text { é t i c a s } \\
\text { Fenotíp. }\end{array}$ & $\begin{array}{l}\text { Her } \\
\text { média }\end{array}$ & $\begin{array}{l}\text { da bi } 1 \text { i } \\
\text { individual }\end{array}$ & $\begin{array}{r}d \text { a d e s } \\
\text { dentro }\end{array}$ \\
\hline 3 & 20,8 & 26,2 & 0,245 & 9,20 & 0,98 & 9,28 & 0,423 & 0,106 & 0,079 \\
\hline 4 & 7,9 & 12,1 & 0,142 & 7,18 & 0,53 & 9,93 & 0,203 & 0,054 & 0,059 \\
\hline 5 & 8,6 & 13,8 & 0,229 & 11,27 & 1,02 & & 0,231 & 0,063 & 0,061 \\
\hline \multicolumn{10}{|c|}{...idem : Procedência Lewotobi } \\
\hline 3 & 21,6 & 27,3 & 0,559 & 9,90 & 2,24 & 10,19 & 0,618 & 0,219 & 0,169 \\
\hline 4 & 8,4 & 12,6 & 0,307 & 8,42 & 1,32 & 10,59 & 0,369 & 0,125 & 0,109 \\
\hline 5 & 8,8 & 13,7 & 0,562 & 13,64 & 2,38 & 18,01 & 0,376 & 0,132 & 0,123 \\
\hline
\end{tabular}

Exp 2, Anhembi-SP:

\begin{tabular}{cccccccccc}
\hline 4 & 31,5 & 24,3 & 121 & 3240 & 485 & 3361 & 0,546 & 0,145 & 0,113 \\
5 & 15,7 & 7,7 & 90 & 2996 & 361 & 3381 & 0,351 & 0,107 & 0,091 \\
6 & 16,5 & 8,0 & 184 & 5258 & 739 & 6044 & 0,370 & 0,122 & 0,105 \\
\hline
\end{tabular}

onde: volume/ ha $=($ vol. cil. $) \times F . F \times(1667$ arv/ha $) \times(1-(\%$ falhas + desbaste/ 100 $))$. 
Cornelius (1994) fez ampla análise dos resultados de 67 trabalhos florestais publicados, comparando herdabilidades e coeficientes genéticos de variação. Encontrou que as herdabilidades tendem a ser baixas, entre 0,18 a 0,26, e os valores individuais estão entre 0,1 a 0,4. Evidenciou que as herdabilidades para forma tendem a ser mais altas que para as caracteristicas de crescimento, e o volume por árvore mostrou os mais altos níveis nos coeficientes de variação genética aditiva. Comparando com os resultados dos dois experimentos aqui estudados, os valores estão ligeiramente mais baixos que essa média mundial, apesar de que nos trabalhos específicos com eucaliptos, os valores são muito próximos, o que valida as estimativas feitas.

Rezende \& Bertolucci (1993) estudaram a seleção combinada em 45 progênies de E. urophylla em Aracruz - ES, entre os 2 e 7 anos de idade, aplicando a metodologia de Falconer (1981) e obtendo resultados de variâncias e herdabilidades , no sentido restrito ao nivel de médias de familias e de individuos dentro de familias, muito próximos ao deste estudo e todos dentro da faixa normalmente observada para experimentos com eucaliptos do subgênero Symphyomyrtus. Houve um aumento significativo nas estimativas de herdabilidade até os 4 anos, com os valores se estabilizando a seguir, indicando ser esta a idade minima para aplicar a seleção precoce. O ganho indireto anual com a seleção combinada nessa idade foi $56 \%$ superior ao mesmo ganho obtido da mesma forma aos 7 anos, evidenciando as vantagens de reduzir cada ciclo seletivo em 3 anos, pois $74 \%$ das árvores selecionadas aos 7 anos já podem ser selecionadas aos 4 anos, o que foi confirmado pelo método de Hamblin \& Zimmermann (1986) citado pelos autores. Infelizmente nada foi informado sobre a procedência do genótipo usado, o que permitiria maiores interpretações sobre os resultados. Mas isto confirma que o desbaste realizado neste estudo é válido e seria vantajoso aplicar a seleção nesta idade ao redor de 4 anos, pois os valores são altamente correlacionados com idades adultas.

Torggler (1987) estudou, em 3 locais do estado de S. Paulo, a variação genética entre progênies dentro de 8 procedências de E. saligna, encontrando diferenças significativas para todos os tratamentos e parâmetros, com maior variação genética para altura das plantas e mantendo as mesmas tendências com o avanço da idade. 
As estimativas de herdabilidade para médias de progênies foram altas e, segundo a autora, não muito consistentes devido aos altos desvios padrões que mudam com as idades, não seguindo uma tendência comum nos vários locais. Concluiu também que a amostragem nas populações deve ter prejudicado a estimativa dos parâmetros genéticos, levando a cautela na interpretação, pois a variabilidade real da população pode ser subestimada. E ainda segundo Torggler (1987), as estimativas de ganhos para seleção dentro das procedências se mostraram razoáveis, indicando a viabilidade do aproveitamento dos materiais genéticos para futuras estratégias de melhoramento.

Em comparação com os resultados deste estudo, pode-se concluir que os mesmos comentários são aplicáveis, com ganhos também bastante viáveis que demonstram o alto potencial destes materiais para programas de melhoramento. 


\subsection{3 - ESTRATÉGIAS PARA CONTINUIDADE}

Os materiais genéticos estudados apresentaram alto potencial de resposta à seleção, devendo haver prosseguimento dos trabalhos de melhoramento na próxima geração, para uso de sementes na região e mesmo introdução em situações ecológicas (clima/ solo) semelhantes, concordando com Matheson (1988).

Com a avaliação a nivel da llha Flores, resultante do agrupamento das duas populações que estão geograficamente distantes na origem, pode-se obter uma grande diferença entre as médias de diâmetro, altura e volume. Isto indica um potencial maior para explorar via melhoramento genético, caso seja enfocado o experimento como um todo, ao permitir a recombinação entre todas as progênies das duas populações, o que jamais se verificaria em condições naturais.

Isto é chamado de ampliação da base genética, ao permitir oportunidades para que novas combinações sejam criadas e possam ser testadas no novo ambiente onde a espécie está sendo introduzida e melhorada, o que ampliaria a variabilidade e, consequentemente, as chances de adaptação para as próximas gerações. Obviamente, a recombinação não segue proporções constantes e definidas em todos os cruzamentos.

Como ocorre uma dispersão do florescimento dentro de cada população, muitos individuos não participam da recombinação, ao passo que outros encontram condições ideais para transferir seus genes para a próxima geração. E a cada ano esse resultado se altera, pois ocorre uma alternância da fenologia individual, não sincronizada, mas casual ou resultante da interação genótipo $X$ ambiente. Assim, as frequentes variações climáticas acabam promovendo um fluxo gênico mais abrangente ao longo de décadas, considerando assim toda a população dentro de um equilíbrio dinâmico.

Deve-se ressaltar que para uma recombinação efetiva, com a quebra de blocos gênicos e restabelecendo o equilibrio de ligação das frequências gênicas, estima-se 
serem necessárias no mínimo duas ou três gerações de melhoramento. Os comentários de Martins-Corder et al. (1996) concordam com essa hipótese, sendo que estes autores estudaram E. urophylla de Anhembi-SP, a mesma procedência que originou o experimento 2. Determinaram altos níveis de polimorfismo isoenzimático que reflete uma ampla base genética, provavelmente fruto de uma amostragem adequada do material que é genuinamente variável, além de que a seleção realizada não trouxe perdas na variabilidade alozímica. Citando Mitton (1989), estes autores ressaltam que as características de crescimentol produtividade e as isoenzimas estão muito relacionadas com os sistemas adaptativos, com a seleção para crescimento podendo trazer maior uniformidade enzimática. Lembrando Zobel \& Talbert (1984), a manutenção dessa variabilidade é fundamental para os programas de melhoramento, pois populações com maior variabilidade são menos vulneráveis às adversidades ambientais por apresentarem maior potencial adaptativo.

Foi levantada uma provável explicação para a correlação do tipo de casca com a produtividade, em termos de genética dessas populações arbóreas, conforme discutido com Mori, 1997¹. Cada procedência teria suas combinações (grupos de genes ligados) em função da pressão de seleção imposta pelo seu ambiente evolutivo. Essas combinações se somariam às ligações casuais de características secundárias, morfológicas, não necessariamente adaptativas, como por exemplo cores, formas ou aparências. Haveria uma certa dificuldade ao se promover o intercâmbio gênico (através de crossing-over) completo entre os individuos pertencentes a várias populações de origens distintas, pelo menos na primeira geração recombinada.

Isto inclusive poderia influenciar na correta estimativa e nas conclusões sobre os parâmetros genéticos em populações ainda não estabilizadas, ou com equilibrio gênico em andamento, conforme ainda discutido em Mayr ( 1977), sobre a genética e a ecologia da especiação. Este autor debate as idéias sobre a base genética do polimorfismo, ou seja, diferentes "tipos" coexistindo na mesma população, como no caso estudado da casca do E. urophylla.

\footnotetext{
${ }^{1}$ MORI, E.S., Depto. Genética e Melhoramento, UNESP, Botucatu. Comunicação pessoal.
} 
Ainda segundo Mayr ( 1977), a chamada ação pleiotrópica de genes é a chave para a solução de muitos fenômenos esquisitos. A permanência de um gene no patrimônio gênico de uma população sob seleção depende de sua contribuição total à "adaptabilidade" e não da contribuição de um fenótipo visível à adaptabilidade. Padrões como cor ou detalhes estruturais podem ser um co-produto acidental de um gene conservado por outras propriedades fisiológicas. Assim seria explicado o sucesso evolutivo de caracteres aparentementemente insignificantes ou inúteis, que passam a fazer parte de um estoque de variabilidade intrapopulacional que é mantido por mecanismos especificos, muitas vezes não diretamente selecionáveis.

Portanto, levanta-se dúvidas sobre a eficiência e a utilidade de futuros trabalhos de classificação desses materiais, através de estudos estatisticos e hierárquicos que procurem correlação entre categorias morfológicas e ganhos de produtividade. As interpretações desses resultados paramétricos não podem se dissociar nem da realidade fenotipica de campo ( ideotipo visto como um todo e não só em uma ou duas caracteristicas isoladas) e nem da visão de longo prazo do melhoramento da população

Abaixo. exemplo de arquitetura de copas: dificuidade na classificação:

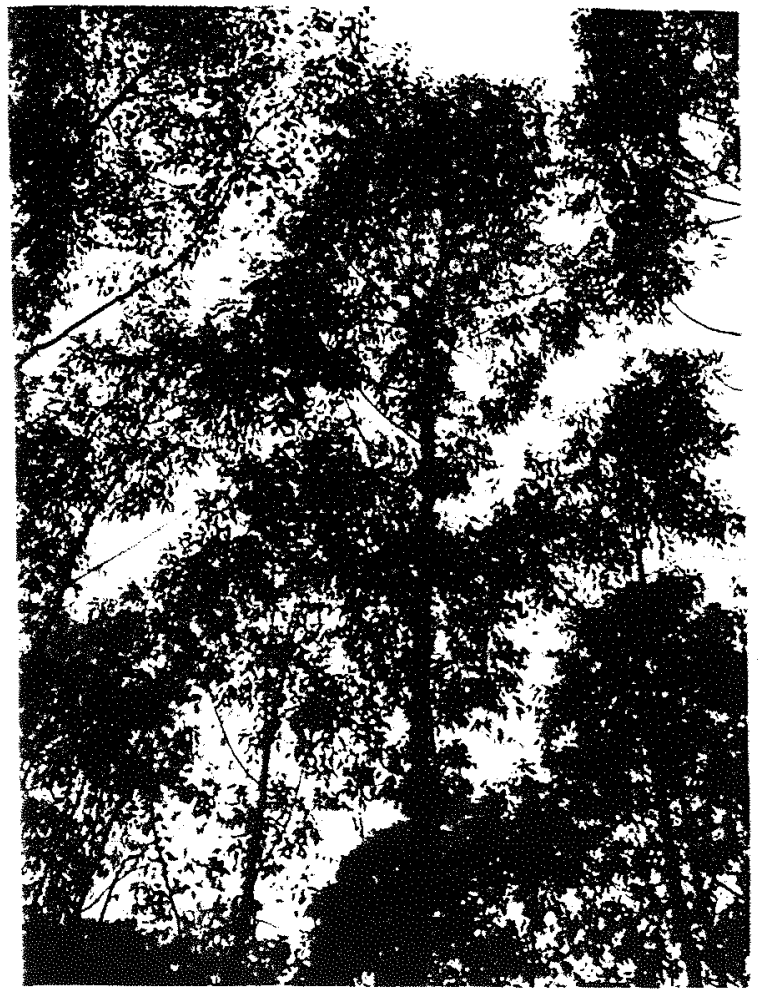

Casca fibrosa escura "trophylla" copa mais fechada folhas horizontais

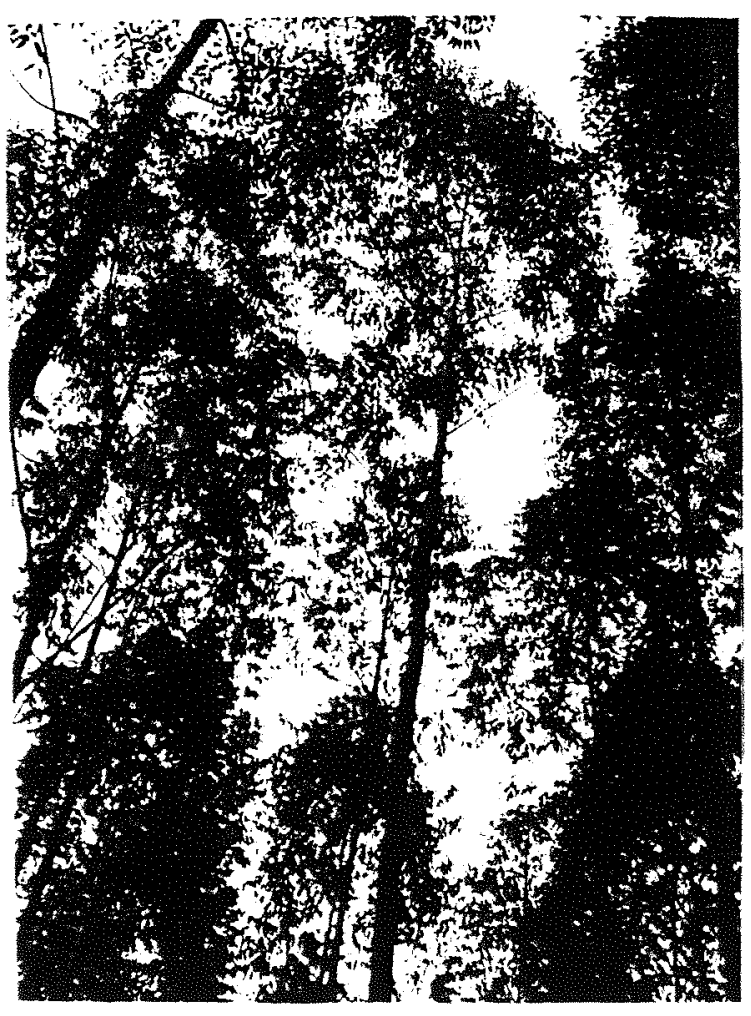

Casca lisa clara "platyphylla" Copa mais aberta. folhas pendentes 


\section{5 - CONCLUSÕES}

Com base em todos os resultados apresentados, para os dois experimentos estudados nas diversas idades, pode-se concluir que :

a) Para as populações naturais do exp.1 (Ilha Flores), a procedência e as progênies de Lewotobi possuem melhor potencial produtivo, em relação a Egon. A procedência Lewotobi, devido aos maiores valores de variância genética aditiva e de herdabilidades, também obteve os maiores ganhos, que demonstram seu maior potencial de melhoramento.

b) A melhor estratégia de seleção neste caso, para maximizar ganhos com menor perda de genótipos, será utilizar a seleção massal na procedência Lewotobi para a formação de um Pomar de Sementes por Mudas, com nivel de seleção acima da upop. Já para a procedência Egon, com menor potencial de melhoramento, a seleção sequencial resultará em melhores ganhos porcentuais e redução adequada no número de famílias, utilizando as progênies acima da $\mu p o p$, e dentro destas, as árvores com DAP acima de $\mu p g$;

c) Nas populações naturais, não devem ser aplicadas intensidades de seleção acima da média da população + mais um desvio ( $\mu$ pop+opop). Isto evita uma drástica redução na base genética, e permite que a recombinação possa ocorrer, pelo menos, por mais uma geração para ser mais efetiva.

d) Para a população recombinada e selecionada do exp.2 (multiprocedência de Outras llhas ), o melhor método de seleção é o massal, que da mesma forma que no experimento anterior, alia os maiores ganhos com a menor redução da base 
genética, além de trabalhar adequadamente o ideotipo de casca lisa que ocorre em alta frequência ( > $18 \%$ ).

e) A seleção dirigida para os fenótipos de casca lisa e clara, na populaçãobase de Outras Ilhas em Anhembi, mostrou-se eficiente para aumentar a frequência desse ideotipo na geração seguinte, com a porcentagem de individuos atípicos passando de 15,9 para 18,8 , ou seja, um acréscimo de $20 \%$ em relação ao inicial; apesar de ser menor do que o inicialmente esperado, ainda é um valor significativo.

f) $O$ melhoramento das populações após a recombinação mostra-se muito mais eficiente, pois pode ser selecionada uma gama muito mais ampla de individuos, o que é demonstrado pelos maiores valores de coeficientes de variância e das herdabilidades, resultando em maior possibilidade de ganho genético. Também isto é evidenciado na comparação de superioridade das médias das melhores progênies sobre as piores; aos 5 anos, em Flores é de $24 \%$ e em Outras llhas atinge $56 \%$.

g) A análise dos fenótipos definidos como casca lisa, rugosa e fibrosa, comprovou a grande variação morfológica na origem, que pode ser atribuída à variação natural dentro da espécie. Considera-se também que houve contribuição de hibridação intraespecífica ( entre procedências ) na 1a geração de recombinação na população base multiprocedência, com retrocruzamentos entre os diversos ideotipos naturais.

h) As variações de casca, inicialmente agrupadas em padrões tidos como fixos, sofreram variações de acordo com a época do ano ( estação de crescimento = chuvas e estação seca = maturação e escurecimento da casca), o que causa mudanças no agrupamento dos indivíduos. Porém, a nivel populacional, as frequências de cada um dos grupos sofre pequenas alterações que não se revelaram significativas, principalmente por afetarem as árvores do grupo intermediário, de casca rugosa, ainda em fase de definição pela idade relativamente nova.

i) $O$ efeito do desbaste seletivo, definido pelos métodos de seleção para cada experimento, é marcante sobre os parâmetros genéticos, alterando-os completamente, como esperado. Entretanto, após 2 anos, nas 3 populações 
estudadas, os valores foram retornando à normalidade, indicando que a competição entre plantas está voltando a estratificar as árvores (anteriormente só superiores) em dominantes, co-dominantes e dominadas. Dois anos após o desbaste seletivo, as árvores remanescentes mostram uma nova estratificação, perdendo a uniformidade causada pelo desbaste, expressando novamente seu potencial genético diante da redução da competição.

j) O desbaste seletivo influencia mais as estimativas absolutas dos componentes de variância do que a sua proporção em relação ao total, mostrando uma influência pequena sobre as estimativas das herdabilidades. 


\section{REFERÊNCIAS BIBLIOGRÁFICAS}

ADAM, P. Australian rainforests. Oxford Biogeography series $n^{\circ} 6$. Oxford University Press, 1992, $308 \mathrm{p}$.

ALLARD, R. W. Princípios do melhoramento genético das plantas. Rio de Janeiro, USAID. S. Paulo, Edgar Blücher, 1971. 379 p.

ANDERSON, E. Introgressive hybridization. New York: Hafner Publishing Company, 1968. $109 \mathrm{p}$.

ASHTON, D. H. ; SANDIFORD, E. M. ; Natural hybridisation between Eucalyptus regnans F. Muell. and E. macrorhyncha F. Muell. in the Cathedral Range, Victoria. Australian Journal of Botany, 1988, 36: 1-22.

ASSIS, T.F. Estimativas de herdabilidade e correlações em progênies jovens de Eucalyptus grandis Hill ex-Maiden, Viçosa, 1980. (Mestrado - UFV).

BAEZ, M. N. Variação fenotípica de Eucalyptus saligna Smith, de Itatinga-SP: Árvores superiores, sementes e progênies de polinização livre, Piracicaba, 1994, 79 p. (Mestrado - ESALQ/USP).

BIERWAGEN, R.; LUZ, H. F ; COUTO, H.T. Z.; CAPITANI, L.R. Stand density, progeny and age interaction for third generation selection of Eucalyptus grandis. In: Dieters et al. (eds) Proced. QFRI- IUFRO Conf. - Caloundra, QLD, Australia. Oct, 1996. p.123-126.

BIERWAGEN, R.; LUZ, H.de F:; KLEINIG, D. and MORI, E. S. Seleção e caracterização de árvores superiores hibridas numa população base de Eucalyptus saligna sob estresse nutricional. In: IUFRO Conference on Silviculture and Improvement of Eucalypt, Salvador, Brazil. Proced. EMBRAPA, Centro Nacional de Pesquisa de Florestas, aug.1997. v.1, p.348-354. 
BOLAND, D. J.; BROOKER, M. I.; CHIPPENDALE, G. M.; HALL, N.; HYLAND, B. P. M.; JOHNSTON, R. D.; KLEINIG, D. A.; TURNER, J. D. Forest Trees of Australia. Melbourne, CSIRO, 1994.

BOUVET, J. M. ; VIGNERON, P. Genetic structure of Eucalyptus urophylla $\times$ E. grandis population in the reciprocical recurrent selection scheme in the Congo. In: Dieters et al. (eds) Proceed. QFRI- IUFRO Conf. - Caloundra, QLD, Australia. Oct, 1996. p.127-132.

BOX, G.E.P. ; COX, D.R. An analysis of transformations. Journal Royal Statistical Society (2) : p. 211-253, 1964.

BOX, G.E.P. ; DRAPER, N.R. Empirical model-building and response surfacesadequacy of estimation and the use of transformation. John Willey \& Sons, New York, 1987.669 p.

BREWBAKER, J. L. Genética na agricultura. São Paulo, Polígono / EDUSP, 1969. $218 p$.

BROOKER, M.I.H. ; KLEINIG, D.A. Field guide to Eucalypts - East and Northern Australia. Melbourne, Inkata Press, 1994.

BUENO FILHO, J.S.S. Seleção combinada versus seleção sequencial no melhoramento de populações florestais, Piracicaba, 1992, 96 p. (Mestrado ESALQ/USP).

CAMPINHOS JÚNIOR, E. ; IKEMORI, Y. K. Selection and management of the basic population of Eucalyptus grandis and E. urophylla established at Aracruz for the long term breeding programme. In: Breeding tropical trees: Population structure and genetic improvement strategies in clonal and seedling forestry. Proc. IUFRO Conference, Pattaya, Thayland, Nov. 1988. p. 169-175.

CAPITANI, L.R.; Vieira, F.S.; Mendes, F.S. 1987. Eucalyptus urophylla da Indonésia no vale do Rio Doce. Revista CVRD, 8: p. 37-52.

CHAPERON, $\mathrm{H}$. Amelioration genetique des Eucalyptus hybrides au Congo Bazzaville. In : Third World Consultation on Forest Tree Breeding, 2., Canberra, 1976. Abstracts. Canberra, FAO/IUFRO, 1976. p. 1055-1069.

COTTERILL, P.P. Genetic gains expected from alternative breeding strategies including simple low cost options. Silvae Genetica 1986 (35): 212-223. 
CORNELIUS, J. 1994. Heritabilities and additive genetic coefficients of variation in forest trees. Can.J.For.Res. 24: 372-379.

DOBZHANSKY, T. Genética do processo evolutivo. São Paulo: Editora da Universidade de São Paulo / Editora Polígono, 1973. 453 p.

EINOT, I. \& GABRIEL, K.R. A study of the powers of several methods of multiple comparisons. Journal of American Statistical Association (70) : p. 574-583, 1975.

ELDRIGE, K. G. Breeding systems, variation and genetic improvement of tropical eucalypts. In: Tropical trees variation, breeding and conservation. London: Academic Press, 1976. p.101-8.

ELDRIDGE, K. ; DAVIDSON, J. ; HARWOOD, C. ; WYK, G. van. Eucalypt domestication and breeding. Oxford: Clarendon Press, 1993. 288 p.

ESBRISSE, E. J. ; GOMES, F. S. ; PIRES, I. E. Estabilidade e adaptabilidade genotípica de progênies de Eucalyptus urophylla S.T.Blake na região do Rio Jari - Pará. In: IUFRO Conference on Silviculture and Improvement of Eucalypt, Salvador, Brazil. Proced. EMBRAPA, Centro Nacional de Pesquisa de Florestas, aug.1997. v.1, p.157-162.

FALCONER, D. S. ; MACKAY, T. F. C. Introduction to quantitative genetics. 4 ed. Essex : Longman, 1996. 464 p.

FERREIRA, M. Melhoramento genético : seleção massal e individual. Circular técnica IPEF , Piracicaba : (21): 1-14, 1976.

FERREIRA, M. Interação Genótipo X Ambiente e sua importância na seleção de espécies/ procedências. In: REUNIÃO SOBRE INTERAÇÃO DO GENÓTIPO SOBRE CLIMA E SOLO, 1, 1986. Piracicaba, Anais... Piracicaba: IPEF, p. 16$17,1986$.

FERREIRA, M. Melhoramento e a silvicultura intensiva clonal. IPEF, Piracicaba, (45) : 22-30, 1992.

FERREIRA, M. \& LUZ, H. de F. Uso de arquitetura de mudas na seleção de híbridos de eucalipto de polinização livre. In: PROGRAMAS COOPERATIVOS EM MELHORAMENTO GENÉTICO FLORESTAL, Piracicaba. Anais, Piracicaba, IPEF/ ESALQ-USPI UFVI EMBRAPA, 1988. p. 15-33. 
FERREIRA, M. e SANTOS, P. E. T. dos . Melhoramento genético Florestal dos Eucalyptus no Brasil - Breve histórico e perspectivas. In: IUFRO Conference on Silviculture and Improvement of Eucalypt, Salvador, Brazil. Proced. EMBRAPA, Centro Nacional de Pesquisa de Florestas, aug.1997. v.1, p. 14-34.

FLORENCE, R.G. Eucalypt ecology. Forest and Timber, Sydney, 13 (3): 2-21, 1977.

GOMES, F. P. Curso de estatística experimental. Piracicaba: Livraria Nobel, 1990. $13^{\mathrm{a}}$ ed. $468 \mathrm{p}$.

GOUVEAA, C. F.; MORI, E. S.; BRASIL, M. A. M. ; VALLE, C. F. do e BONINE, C. A. V. Seleção fenotípica por padrão de proporção de casca rugosa persistente em árvores de Eucalyptus urophylla S.T.Blake, visando formação de população base de melhoramento genético para qualidade da madeira. In: IUFRO Conference on Silviculture and Improvement of Eucalypt, Salvador, Brazil. Proced. EMBRAPA, Centro Nacional de Pesquisa de Florestas, aug.1997. v.1, p.355-360.

GRIFFIN, A. R.; BURGESS, I. P.; WOLF, L. Patterns of natural and manipulated hybridization in the genus Eucalyptus L'Herit - a rewiew. Australian Journal of Botany, Melbourne, 36 (1): 41-66. 1988.

GWAZE, D.P.; WOOLLIANS, J. A . ; KANOWSKI, P.J. Predicted genetic gain in height in 23-year-old progeny tests of Pinus taeda in Zimbabwe, and inferences for the optimum age of selection. In: Dieters et al. (eds) Proced. QFRI - IUFRO Conf.-Caloundra,QLD, Australia. Oct, 1996. p.148-153.

HARDIYANTO, E. B. Genetic parameter estimates for stem form and diameter in two Pinus merkusii progeny tests in Java, Indonesia. In: Dieters et al. (eds) Proced. QFRI- IUFRO Conf. - Caloundra, QLD, Australia. Oct, 1996. p. 204-05.

HARWOOD, C.E.; NIKLES, D.G.; POMROY, P; ROBSON, K. Impact of thinning via phenotypic selection on the genetic base of planted seed production areas. In: Dieters et al. (eds) Proced. QFRI- IUFRO Conf.-Caloundra,QLD, Australia. Oct, 1996. p.148-153.

HIGA, A. H. ; RESENDE, M. D. V. ; SOUZA, S. M. Programas de melhoramento genético de Eucalyptus no Brasil. Curitiba, CNPF-EMBRAPA, 1992. s.p. 
HODGSON, L. M. Breeding of eucalypts in South Africa. South Africa Forestry Journal, Pretoria (89): 13-15. 1974.

JONES, D. A . ; WILKINS, D. A . Variation and adaptation in plant species. Heineman Educational Books, London, 1971. 184 p.

KAGEYAMA, P.Y. Seleção precoce a diferentes idades em progênies de Eucalyptus grandis Hill ex-Maiden. Piracicaba, 1983. 147 p. (Livre Docência - ESALQ/USP).

KAGEYAMA, P. Y. ; KIKUTI, P. Comparison between clones and open-pollinated progenies originating from a population of Eucalyptus grandis in Brazil. In: Breeding tropical trees: Population structure and genetic improvement strategies in clonal and seedling forestry. Proc. IUFRO Conference, Pattaya, Thayland, Nov. 1988. p. 227-235.

KIKUTI, P. Parâmetros genéticos em progênies de meios irmãos e clonais numa população de Eucalyptus grandis (Hill) Maiden na região de Telêmaco Borba PR. Piracicaba, 1988. 119 p. ( Mestrado - ESALQ/USP).

LÓPEZ, C.R. Variação fenotípica e genética em clones de Eucalyptus urophylla S.T. Blake da Ilha Flores (Indonésia). Piracicaba, 1992. 101 p. (Tese Mestrado ESALQ/ USP).

LUZ, H. de F.; BIERWAGEN, R.; FERREIRA, M.; CAPITANI, L. R. Population studies and selection strategies of Eucalyptus urophylla. In: Tree Improvement for Sustainable Tropical Forestry. Proc. QFRI-IUFRO Conf., Caloundra, Queensland, Australia.1996. p. 138-42.

LUZ, H. F.; BIERWAGEN, R.; CAPITANI, L.R.; FERREIRA, M. Efeitos do desbaste seletivo numa população de Eucalyptus urophylla. In: Conferência IUFRO sobre Silvicultura e Melhoramento de Eucaliptos, Salvador, 1997. EMBRAPA, Anais, p. $139-144$.

MARTIN, B. \& COSSALTER, C. Les Eucalyptus des iles de la Sonde. Bois et Forêts des Tropiques, Nogent-sur-Marne, (163): 3-25. 1975.

MARTIN, B. \& COSSALTER, C. Les Eucalyptus des iles de la Sonde. Bois et Forêts des Tropiques, Nogent-sur-Marne, (164): 3-14. 1975.

MARTIN, B. \& COSSALTER, C. Les eucalypts des iles de la Sonde. Bois et Forêts des Tropiques, Nogent-sur Marne, (165): 3-20. 1976. 
MARTIN, B. \& COSSALTER, C. Les Eucalyptus des iles de la Sonde. Bois et Forêts des Tropiques, Nogent-sur-Marne, (166): 3-22. 1976.

MARTINS-CORDER, M. P. ; MORI, E. S. ; KAGEYAMA, P. Y. ; LOPES, C. R. Estudo da variabilidade enzimática em Eucalyptus urophylla da llha Flores. Scientia Forestalis, IPEF, Piracicaba, (50): 43-49, 1996.

MATHESON, A. C. Statistical methods and problems in testing large numbers of genotypes across sites. In: Breeding tropical trees: Population structure and genetic improvement strategies in clonal and seedling forestry. Proc. IUFRO Conference, Pattaya, Thayland, Nov. 1988. P. 93-105.

MAYR, E. Populações, espécies e evolução. São Paulo, EDUSP. 1977. 485 p.

MITCHEL BEAZLEYI IUCN. The last rain forests. World Conservation Atlas. Mitchel Beazley International, London, 1990. 200 p.

MORI, E. S. Efeitos da competição intra-especifica na seleção de árvores superiores de Eucalyptus saligna Smith. Piracicaba, 1987. ( T. Mestrado - ESALQ/ USP).

MORI, E. S. Variabilidade genética isoenzimática em uma população de Eucalyptus grandis Hill ex Maiden submetida a diferentes intensidades de seleção. Piracicaba, 1993. 119 p. ( T. Doutorado - ESALQ/ USP).

MORI, E.S.; KAGEYAMA, P.Y. \& FERREIRA, M. Variação genética e interações progênies versus locais em Eucalyptus urophylla. Revista IPEF, Piracicaba, (39): 53-63, 1988.

MOURA, V. P. G. Altitudinal variation in Eucalyptus urophylla S.T.Blake. Melbourne, 1977. Thesis ( M.S.). University of Melbourne.

MOURA, V. P. G. Resultado da pesquisa com com várias procedências de Eucalyptus urophylla S.T.Blake, no centro-leste do Brasil. Boletim de Pesquisa. EMBRAPA/ CPAC, Planaltina, 3: 1-22, 1981.

NAMKOONG, G. Introduction to quantitative genetics in forestry. USDA-Forest Service, Technical Bulletin no 1588, USA, 1979. 342p.

ODA, S.; MENCK, A.L.M. \& VENCOVSKY, R. Problemas no melhoramento genético do eucalipto em função da alta intensidade de seleção. Revista IPEF. Piracicaba, n. 41, p. 8-17, 1989. 
OLIVEIRA, V. R. de O. Estudos para formação de populações base de Eucalyptus tereticornis Sm. Piracicaba, 1994. ( Tese Mestrado - ESALQ/ USP). 117 p.

PÁSZTOR, Y. P. C. Teste de procedências de Eucalyptus pilularis Sm. na região de Mogi Guaçu. Piracicaba, 1972, $61 \mathrm{p}$.

PÁSZTOR, Y. P. C. ; ETTORI, L. C. ; ZANATTO, A. C. S. ; MORAIS, E. Teste internacional de procedências de Eucalyptus urophylla S.T.Blake. In: CONGRESSO FLORESTAL BRASILEIRO, 6, Campos do Jordão, 1990. SBS, Anais, p. 421-25.

PINYOPUSARERK, K. ; GUNN, B.V.; WILLIAMS, E. R. ; PRYOR, L.D. Comparative geografical variation in seedling morphology of three closely related red mahoganies, Eucalyptus. Urophylla . E. pellita and E. scias . Aust.J.Bot., 1993, 41: $23-34$.

PINTO JUNIOR, J.E. Variabilidade genética em progênies de uma procedência de Eucalyptus urophylla S.T. Blake da Ilha Flores - Indonésia. Piracicaba. 1984. 164 p. (Mestrado - ESALQ/USP).

PRYOR, L. D. Reproductive habits of the eucalypts. Unasylvia, Roma, 30 (119/120): 42-50, 1978.

PRYOR, L.D.; WILLIAMS, E.R.; GUNN, B.V. A morphometric analysis of Eucalyptus urophylla and related taxa with descriptions of two new species. Australian Systematic Botany. 8: p. 57-70

RAMALHO, M. A. P. Emprego da seleção recorrente no melhoramento de essências florestais. In: SIMPÓSIO BRASILEIRO DE PESQUISA FLORESTAL, 1, Belo Horizonte, 1993. Anais... Belo Horizonte, SIF, p. 21-37. 1993.

RESENDE, M. D. V. de ; OLIVEIRA, E. B. ; HIGA, A. H. Utilização de índices de seleção no melhoramento de eucalipto. Bol.Pes.Flor., Curitiba, (21): 1-13, dez.1990. p. 1-13.

RESENDE, M. D. V. de ; RESENDE, R. M. S. Seleção de cruzamentos, recombinação desbalanceada e aumento da eficiência do melhoramento genético de Eucalyptus. In: IUFRO Conference on Silviculture and Improvement of Eucalypt, Salvador, Brazil. Proced. EMBRAPA, Centro Nacional de Pesquisa de Florestas, aug.1997. v.1, p.337-341. 
REZENDE, G. D. S. P. ; BERTOLUCCI, F. L. G. Uso da seleção combinada na determinação da eficiência da seleção precoce em progênies de $E$. urophylla. In: 7o Congr. Florestal Brasileiro/ 1o Panamericano, Curitiba. Anais, SBS, S.Paulo, 1993. p. 158-160.

SAMPAIO, A. N. O eucalipto. Companhia Paulista de Estradas de Ferro, Jundiaí, $1961,667 \mathrm{p}$.

SAS INSTITUTE INC. SAS / STAT users guide ( version 6.09). Cary, USA, 1990. $846 \mathrm{p}$.

SHAPIRO, S.S. ; FRANCIA, R. S. An approximate analysis of variance test for normality . Journal of American Statistical Association, 337(67): p.215-6.

SHAPIRO, S. S. ; WILK, M. B. An analysis of variance test for normality (complete samples). Biometrika (52) : p. 591-611, 1965.

SHAPIRO, S. S. ; WILK, M.B. ; CHEN, H. J. A comparative study of various tests for normality. American Statistical Association Journal, p. 1343-72. Dec.1968

SILVA, R.G. Métodos de genética quantitativa aplicados ao melhoramento animal. Ribeirão Preto: Sociedade Brasileira de Genética, 1982. 161 p.

SWALLOW, W. H. ; MONAHAN, J. F. Monte Carlo comparison of ANOVA, MIVQUE, REML and ML estimators of variance components. Technometrics. 26: p. 4757.

TORGGLER, M. G. F. Variação genética entre progênies dentro de procedências de Eucalyptus saligna Smith. Piracicaba, 1987. 198 p. (Mestrado, ESALQ/USP).

VALÉRIO FILHO, W.V. Comparação de métodos para estimação de componentes de variância através de simulação de dados. Piracicaba, 1991. 160 p. (Doutorado ESALQ/ USP).

VENCOVSKY, R. ; BARRIGA, P. Genética biométrica no fitomelhoramento. Ribeirão Preto: Sociedade Brasileira de Genética. 1992. 486 p.

VIEIRA, F.S. ; BUCSAN, B. Relatório da viagem realizada no periodo de maio a agosto de 1977 à República da Indonésia, com a finalidade de coleta de sementes de Eucalyptus urophylla e E. alba. CVRD, 1977, 132 p. (não publicado) 
WALTER, H. Vegetação e zonas climáticas. Tratado de ecologia global. São Paulo, EDUSP, 1986. $326 \mathrm{p}$

XAVIER, A. ; COMÉRIO, J. and AUGUSTO, F. Eficiência da seleção massal em gerações F1 e F2 de Eucalyptus grandis Coff's Harbour. In: IUFRO Conference on Silviculture and Improvement of Eucalypt, Salvador, Brazil. Proced. EMBRAPA, Centro Nacional de Pesquisa de Florestas, aug.1997. v.1, p.145150.

ZOBEL, B. ; TALBERT, J. Applied forest tree improvement. New York, John Wiley \& Sons, 1984. $496 \mathrm{p}$.

\section{BIBLIOGRAFIA RECOMENDADA}

Complementar às citações anteriores, porém de caráter geral, consideradas fundamentais para uma abordagem crítica e ampla, com redação clara e objetiva, atendendo a princípios de metodologia e filosofia de pesquisa atuais

BARRAS, R. Os cientistas precisam escrever: guia de redação para cientistas, engenheiros e estudantes. São Paulo: T. A . Queiroz/ EDUSP, 1979. 218 p.

ECO, U. Como se faz uma tese. Estudos. São Paulo, Editora Perspectiva, 1996. $170 \mathrm{p}$.

ECO, U. ; SEBEOK, T. A . O signo de três. Coleção Estudos. São Paulo, Editora Perspectiva, 1991. $263 \mathrm{p}$.

GRANGER, G.G. A ciência e as ciências. São Paulo, Editora da Universidade Estadual Paulista,1994.122 p. 
ANEXOS

ANEXO 1:

TABELAS COMPLETAS COM DADOS POR PROGÊNIE 
TABELAS COMPLETAS COM DADOS DE TODAS AS PROGÊNIES DO EXP.1:

POPULAÇÕES SELVAGENS

Tabela 42: Estatísticas básicas (descritivas) ao nivel de progênie, aos 3 anos de idade, para 0 experimento 1: E urophylla, Bofete-SP, 1994.

\begin{tabular}{|c|c|c|c|c|c|c|c|c|c|}
\hline $\begin{array}{c}\text { FST } 3 \\
\text { Progenie } n^{\circ}\end{array}$ & $\begin{array}{l}\text { Núm. } \\
\text { Arvores }\end{array}$ & $\begin{array}{l}\text { Falha } \\
\text { (\%) }\end{array}$ & $\begin{array}{l}\text { Volume } \\
\text { (m3) }\end{array}$ & $\begin{array}{l}\text { Volume } \\
\text { por ha } \\
\text { (m3/ha) }\end{array}$ & $\begin{array}{l}\text { Altura } \\
(\mathrm{m}) \\
\end{array}$ & $\begin{array}{l}\text { DAP } \\
(\mathrm{cm}) \\
\end{array}$ & DAP_Q & $\begin{array}{c}\text { CV } \\
\text { altura } \\
(\%) \\
\end{array}$ & $\begin{array}{c}\text { CV } \\
\text { DAP (\%) }\end{array}$ \\
\hline 1 & 21 & 13 & 0.079 & 114.74 & 14.12 & 11.70 & 12.12 & 22.20 & 27.50 \\
\hline 2 & 23 & 4 & 0.095 & 151.28 & 15.61 & 12.86 & 12.99 & 8.85 & 14.58 \\
\hline 3 & 22 & 8 & 0.087 & 132.79 & 15.43 & 12.27 & 12.46 & 10.31 & 18.22 \\
\hline 4 & 24 & 0 & 0.081 & 135.83 & 13.77 & 12.07 & 12.45 & 23.82 & 25.93 \\
\hline 5 & 23 & 4 & 0.064 & 101.72 & 13.50 & 10.45 & 10.99 & 22.02 & 33.18 \\
\hline 6 & 22 & 8 & 0.087 & 133.53 & 15.34 & 12.40 & 12.57 & 9.24 & 17.18 \\
\hline 7 & 23 & 4 & 0.074 & 118.81 & 14.37 & 11.28 & 11.61 & 22.63 & 24.94 \\
\hline 8 & 23 & 4 & 0.072 & 115.76 & 14.35 & 11.28 & 11.59 & 19.36 & 24.33 \\
\hline 9 & 19 & 21 & 0.082 & 108.10 & 14.63 & 12.13 & 12.36 & 16.38 & 20.29 \\
\hline 10 & 24 & 0 & 0.083 & 138.02 & 14.94 & 12.15 & 12.41 & 10.32 & 21.42 \\
\hline 11 & 22 & 8 & 0.082 & 125.44 & 15.36 & 11.75 & 12.03 & 14.84 & 22.48 \\
\hline 12 & 23 & 4 & 0.065 & 103.31 & 13.65 & 10.78 & 11.23 & 23.62 & 29.73 \\
\hline 13 & 23 & 4 & 0.075 & 119.27 & 13.91 & 11.64 & 11.96 & 24.77 & 24.28 \\
\hline 14 & 23 & 4 & 0.070 & 112.57 & 13.74 & 10.92 & 11.56 & 19.93 & 35.42 \\
\hline 15 & 22 & 8 & 0.071 & 108.49 & 14.00 & 11.00 & 11.49 & 22.37 & 30.94 \\
\hline 16 & 24 & 0 & 0.082 & 137.32 & 14.69 & 11.92 & 12.22 & 24.09 & 22.87 \\
\hline 17 & 23 & 4 & 0.079 & 127.00 & 14.63 & 11.53 & 11.95 & 24.37 & 27.79 \\
\hline 18 & 23 & 4 & 0.067 & 107.37 & 13.17 & 10.35 & 11.08 & 32.72 & 38.98 \\
\hline 19 & 21 & 13 & 0.072 & 104.70 & 14.55 & 10.96 & 11.41 & 17.59 & 29.76 \\
\hline 20 & 23 & 4 & 0.087 & 138.53 & 15.24 & 12.04 & 12.37 & 15.57 & 24.04 \\
\hline 21 & 23 & 4 & 0.068 & 109.06 & 13.04 & 11.11 & 11.61 & 34.65 & 30.86 \\
\hline 22 & 22 & 8 & 0.114 & 173.51 & 16.77 & 13.61 & 13.75 & 9.28 & 14.59 \\
\hline 23 & 22 & 8 & 0.070 & 106.84 & 13.91 & 10.98 & 11.42 & 19.83 & 29.22 \\
\hline 24 & 20 & 17 & 0.073 & 101.53 & 14.25 & 10.90 & 11.40 & 26.22 & 31.27 \\
\hline \multicolumn{10}{|l|}{ Lewotobi } \\
\hline 25 & 20 & 17 & 0.075 & 103.54 & 13.95 & 10.79 & 11.51 & 29.60 & 37.98 \\
\hline 26 & 24 & 0 & 0.125 & 207.63 & 16.04 & 14.15 & 14.46 & 23.82 & 21.38 \\
\hline 27 & 22 & 8 & 0.107 & 162.83 & 15.25 & 13.02 & 13.55 & 21.70 & 29.57 \\
\hline 28 & 23 & 4 & 0.082 & 131.04 & 14.91 & 11.90 & 12.18 & 16.29 & 22.33 \\
\hline 29 & 24 & 0 & 0.071 & 118.26 & 13.60 & 11.14 & 11.61 & 21.86 & 29.81 \\
\hline 30 & 23 & 4 & 0.085 & 136.09 & 14.13 & 11.79 & 12.39 & 27.62 & 32.92 \\
\hline 31 & 22 & 8 & 0.078 & 118.64 & 14.66 & 11.40 & 11.84 & 18.48 & 28.60 \\
\hline 32 & 24 & 0 & 0.095 & 157.96 & 15.96 & 12.25 & 12.62 & 14.87 & 25.19 \\
\hline 33 & 22 & 8 & 0.078 & 119.18 & 14.34 & 11.65 & 12.01 & 17.98 & 25.92 \\
\hline 34 & 22 & 8 & 0.079 & 121.30 & 14.68 & 11.66 & 12.01 & 20.42 & 25.26 \\
\hline
\end{tabular}


Tabela 43: Estatísticas básicas (descritivas) ao nível de progênie, aos 4 anos de idade, para o experimento 1: E urophylla, Bofete-SP, 1995.

\begin{tabular}{|c|c|c|c|c|c|c|c|c|c|}
\hline $\begin{array}{c}\text { FST } 4 \\
\text { Progenie } \\
n^{\circ} \\
\end{array}$ & $\begin{array}{l}\text { Núm. } \\
\text { Arvores }\end{array}$ & $\begin{array}{l}\text { Falha } \\
\quad(\%) \\
\end{array}$ & $\begin{array}{l}\text { Volume } \\
\text { (m3/arv) }\end{array}$ & $\begin{array}{c}\text { Volume } \\
\text { por ha } \\
\text { (m3/ha) }\end{array}$ & $\begin{array}{l}\text { Altura } \\
+(\mathrm{m}) \\
\end{array}$ & $\begin{array}{l}\text { DAP } \\
(\mathrm{cm}) \\
\end{array}$ & $\begin{array}{r}\text { DAPQ } \\
(\mathrm{m}) \\
\end{array}$ & $\begin{array}{c}\text { CV } \\
\text { altura } \\
(\%) \\
\end{array}$ & $\begin{array}{l}\text { CV } \\
\text { DAP } \\
(\%) \\
\end{array}$ \\
\hline \multicolumn{10}{|l|}{ EGON } \\
\hline 1 & 15 & 38 & 0.133 & 138.07 & 17.27 & 14.62 & 14.67 & 9.21 & 8.84 \\
\hline 2 & 19 & 21 & 0.137 & 181.22 & 17.66 & 14.69 & 14.78 & 7.00 & 11.03 \\
\hline 3 & 13 & 46 & 0.150 & 135.87 & 17.85 & 15.25 & 15.38 & 6.20 & 13.51 \\
\hline 4 & 15 & 38 & 0.142 & 148.16 & 17.03 & 15.19 & 15.30 & 9.51 & 12.02 \\
\hline 5 & 9 & 63 & 0.150 & 93.78 & 18.11 & 15.14 & 15.27 & 5.82 & 14.23 \\
\hline 6 & 15 & 38 & 0.137 & 143.15 & 17.60 & 14.73 & 14.83 & 4.94 & 12.16 \\
\hline 7 & 12 & 50 & 0.141 & 117.33 & 17.83 & 14.80 & 14.85 & 8.65 & 8.68 \\
\hline 8 & 12 & 50 & 0.147 & 122.72 & 17.96 & 15.12 & 15.19 & 6.22 & 10.29 \\
\hline 9 & 14 & 42 & 0.130 & 126.27 & 17.07 & 14.57 & 14.61 & 9.94 & 7.38 \\
\hline 10 & 14 & 42 & 0.146 & 142.34 & 17.46 & 15.21 & 15.30 & 10.01 & 11.35 \\
\hline 11 & 12 & 50 & 0.151 & 125.71 & 18.21 & 15.25 & 15.28 & 7.54 & 6.38 \\
\hline 12 & 9 & 63 & 0.137 & 85.64 & 18.28 & 13.60 & 14.45 & 8.44 & 37.97 \\
\hline 13 & 14 & 42 & 0.124 & 120.46 & 17.07 & 13.94 & 14.18 & 8.96 & 19.44 \\
\hline 14 & 12 & 50 & 0.152 & 126.51 & 17.71 & 15.41 & 15.50 & 9.74 & 11.12 \\
\hline 15 & 12 & 50 & 0.144 & 120.12 & 18.17 & 14.91 & 14.95 & 6.14 & 7.50 \\
\hline 16 & 15 & 38 & 0.146 & 151.95 & 18.03 & 14.83 & 14.98 & 8.54 & 14.44 \\
\hline 17 & 13 & 46 & 0.148 & 133.33 & 18.12 & 15.11 & 15.18 & 5.06 & 10.02 \\
\hline 18 & 12 & 50 & 0.147 & 122.29 & 17.46 & 15.25 & 15.36 & 5.79 & 12.44 \\
\hline 19 & 11 & 54 & 0.140 & 106.66 & 17.86 & 14.70 & 14.81 & 4.70 & 12.73 \\
\hline 20 & 14 & 42 & 0.142 & 137.84 & 17.79 & 14.78 & 14.96 & 4.51 & 16.51 \\
\hline 21 & 11 & 54 & 0.143 & 109.17 & 17.64 & 14.96 & 15.07 & 7.83 & 12.77 \\
\hline 22 & 17 & 29 & 0.184 & 217.43 & 18.27 & 16.29 & 15.88 & 27.21 & 10.24 \\
\hline 23 & 9 & 63 & 0.167 & 104.61 & 18.50 & 15.88 & 15.98 & 8.22 & 12.00 \\
\hline 24 & 10 & 58 & 0.139 & 96.33 & 17.70 & 14.67 & 14.81 & 6.82 & 14.22 \\
\hline \multicolumn{10}{|l|}{ LEWOTOBI } \\
\hline 25 & 8 & 67 & 0.183 & 101.71 & 18.75 & 16.47 & 16.59 & 8.06 & 12.81 \\
\hline 26 & 19 & 21 & 0.195 & 257.57 & 19.26 & 16.62 & 16.80 & 6.89 & 15.40 \\
\hline 27 & 16 & 33 & 0.170 & 189.27 & 18.44 & 16.01 & 16.16 & 7.73 & 13.90 \\
\hline 28 & 13 & 46 & 0.154 & 139.51 & 18.15 & 15.45 & 15.48 & 8.44 & 6.66 \\
\hline 29 & 12 & 50 & 0.152 & 126.83 & 17.88 & 15.38 & 15.47 & 5.98 & 11.24 \\
\hline 30 & 13 & 46 & 0.178 & 160.71 & 18.78 & 16.21 & 16.35 & 6.39 & 13.97 \\
\hline 31 & 14 & 42 & 0.139 & 135.07 & 17.89 & 14.69 & 14.76 & 9.88 & 10.09 \\
\hline 32 & 16 & 33 & 0.171 & 189.86 & 19.03 & 15.78 & 15.86 & 6.61 & 10.78 \\
\hline 33 & 11 & 54 & 0.147 & 112.48 & 17.27 & 15.28 & 15.39 & 12.10 & 12.84 \\
\hline 34 & 13 & 46 & 0.133 & 120.03 & 17.04 & 14.72 & 14.82 & 10.06 & 12.18 \\
\hline
\end{tabular}


Tabela 44: Estatísticas básicas (descritivas) ao nível de progênie, aos 5 anos de idade, para o experimento 1: E urophylla, Bofete-SP, 1994.

\begin{tabular}{|c|c|c|c|c|c|c|c|c|c|}
\hline 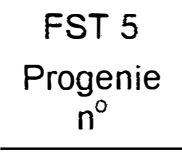 & $\begin{array}{l}\text { Núm. } \\
\text { Arvores }\end{array}$ & Falha & Volume & $\begin{array}{c}\text { Volume } \\
\text { por ha } \\
(\mathrm{m} 3 / \mathrm{ha})\end{array}$ & Altura & DAP & DAPQ & $\begin{array}{c}\text { CV } \\
\text { altura } \\
(\%)\end{array}$ & $\begin{array}{l}\text { CV } \\
\text { DAP } \\
(\%) \\
\end{array}$ \\
\hline \multicolumn{10}{|l|}{ EGON } \\
\hline 1 & 15 & 38 & 0.174 & 181.21 & 19.27 & 15.89 & 15.96 & 7.96 & 9.35 \\
\hline 2 & 19 & 21 & 0.184 & 242.26 & 20.03 & 15.93 & 16.04 & 8.00 & 12.22 \\
\hline 3 & 13 & 46 & 0.214 & 193.58 & 20.69 & 16.82 & 17.00 & 8.05 & 15.06 \\
\hline 4 & 15 & 38 & 0.177 & 184.42 & 19.27 & 15.94 & 16.05 & 6.79 & 12.30 \\
\hline 5 & 9 & 63 & 0.188 & 117.77 & 19.67 & 16.23 & 16.40 & 4.76 & 15.41 \\
\hline 6 & 15 & 38 & 0.176 & 183.23 & 19.37 & 15.83 & 15.97 & 5.97 & 13.56 \\
\hline 7 & 12 & 50 & 0.189 & 157.85 & 20.17 & 16.21 & 16.27 & 6.71 & 9.08 \\
\hline 8 & 12 & 50 & 0.203 & 168.98 & 20.54 & 16.63 & 16.69 & 4.34 & 9.09 \\
\hline 9 & 14 & 42 & 0.171 & 166.48 & 19.54 & 15.60 & 15.68 & 7.61 & 10.47 \\
\hline 10 & 14 & 42 & 0.196 & 190.78 & 19.64 & 16.46 & 16.61 & 11.00 & 14.16 \\
\hline 11 & 12 & 50 & 0.214 & 178.72 & 20.75 & 17.00 & 17.06 & 8.44 & 8.20 \\
\hline 12 & 9 & 63 & 0.197 & 123.29 & 20.44 & 16.27 & 16.47 & 3.95 & 16.53 \\
\hline 13 & 13 & 46 & 0.179 & 161.84 & 19.50 & 15.92 & 16.02 & 7.48 & 11.92 \\
\hline 14 & 12 & 50 & 0.207 & 172.52 & 19.75 & 17.06 & 17.18 & 4.64 & 12.54 \\
\hline 15 & 11 & 54 & 0.190 & 145.24 & 20.18 & 16.20 & 16.27 & 6.76 & 9.11 \\
\hline 16 & 15 & 38 & 0.190 & 198.32 & 20.43 & 15.96 & 16.14 & 6.66 & 15.54 \\
\hline 17 & 13 & 46 & 0.194 & 175.54 & 20.04 & 16.45 & 16.53 & 6.72 & 9.91 \\
\hline 18 & 12 & 50 & 0.191 & 159.24 & 19.75 & 16.37 & 16.48 & 9.06 & 12.20 \\
\hline 19 & 11 & 54 & 0.183 & 139.90 & 19.77 & 15.97 & 16.10 & 6.73 & 13.18 \\
\hline 20 & 14 & 42 & 0.190 & 184.73 & 20.00 & 15.96 & 16.21 & 9.46 & 18.41 \\
\hline 21 & 11 & 54 & 0.187 & 142.54 & 19.23 & 16.29 & 16.45 & 8.81 & 14.75 \\
\hline 22 & 15 & 38 & 0.239 & 249.21 & 21.43 & 17.68 & 17.76 & 7.37 & 10.25 \\
\hline 23 & 9 & 63 & 0.210 & 131.44 & 20.94 & 16.73 & 16.88 & 8.48 & 14.15 \\
\hline 24 & 10 & 58 & 0.178 & 123.33 & 20.05 & 15.50 & 15.67 & 8.35 & 15.52 \\
\hline \multicolumn{10}{|l|}{ LEWOT } \\
\hline 25 & 8 & 67 & 0.248 & 137.98 & 21.25 & 17.87 & 18.05 & 10.37 & 15.22 \\
\hline 26 & 19 & 21 & 0.243 & 320.31 & 21.03 & 17.67 & 17.88 & 9.69 & 15.73 \\
\hline 27 & 16 & 33 & 0.220 & 244.71 & 20.94 & 17.01 & 17.19 & 5.64 & 14.91 \\
\hline 28 & 13 & 46 & 0.201 & 181.68 & 20.31 & 16.63 & 16.67 & 9.02 & 7.70 \\
\hline 29 & 12 & 50 & 0.194 & 161.90 & 19.88 & 16.42 & 16.55 & 8.85 & 13.24 \\
\hline 30 & 13 & 46 & 0.233 & 210.58 & 20.31 & 17.78 & 17.94 & 8.01 & 14.02 \\
\hline 31 & 14 & 42 & 0.191 & 185.58 & 20.36 & 16.12 & 16.23 & 9.51 & 12.01 \\
\hline 32 & 16 & 33 & 0.227 & 252.20 & 21.44 & 17.09 & 17.20 & 6.48 & 11.60 \\
\hline 33 & 11 & 54 & 0.205 & 156.31 & 20.55 & 16.58 & 16.71 & 8.46 & 13.20 \\
\hline 34 & 12 & 50 & 0.181 & 150.64 & 18.88 & 16.23 & 16.39 & 10.78 & 14.34 \\
\hline
\end{tabular}


Tabela 45 - Frequência de árvores desbastadas, falhas de plantio, mortas, quebradas, bifurcadas acima do DAP e de árvores normais, aos 4 anos de idade, para o exp1:

\begin{tabular}{|c|c|c|c|c|}
\hline Categoria & $\begin{array}{c}\text { F.A.S. } \\
\text { (arv) }\end{array}$ & $\begin{array}{c}\text { F.A.A. } \\
\text { (arv) }\end{array}$ & $\begin{array}{c}\text { F.R.S. } \\
(\%)\end{array}$ & $\begin{array}{c}\text { F.R.A. } \\
(\%)\end{array}$ \\
\hline \multicolumn{5}{|l|}{ Egon } \\
\hline Normal & 299 & 299 & 51.9 & 51.9 \\
\hline Desbaste & 222 & 521 & 38.5 & 90.5 \\
\hline Falha & 21 & 542 & 3.6 & 94.1 \\
\hline Morta & 27 & 569 & 4.7 & 98.8 \\
\hline Quebrada & 1 & 570 & 0.2 & 99.0 \\
\hline Bifurcada & 6 & 576 & 1.0 & 100.0 \\
\hline \multicolumn{5}{|l|}{ Acima do DAP } \\
\hline \multicolumn{5}{|l|}{ Lewotobi } \\
\hline Normal & 129 & 129 & 53.8 & 53.8 \\
\hline Desbaste & 90 & 219 & 37.5 & 91.3 \\
\hline Falha & 8 & 227 & 3.3 & 94.6 \\
\hline Morta & 7 & 234 & 2.9 & 97.5 \\
\hline Quebrada & 1 & 235 & 0.4 & 97.9 \\
\hline Bifurcada & 5 & 240 & 2.1 & 100.0 \\
\hline Acima do DAP & & & & \\
\hline
\end{tabular}

Onde:

F.A.S. $=$ frequência absoluta simples

F.A.A $=$ frequência absoluta acumulada

F.R.S. = frequência relativa simples

F.R.A. = frequência relativa acumulada 
TABELAS COMPLETAS COM DADOS DE TODAS AS PROGÉNIES DO EXP.2:

\section{POPULAÇÃO RECOMBINADA}

Tabela 46. Estatísticas básicas (descritivas) ao nível de progênie, aos 4 anos de idade, para o experimento 2. E. urophylla, Anhembi-SP.

\begin{tabular}{|c|c|c|c|c|c|c|c|c|c|}
\hline Progenie & $\begin{array}{l}\text { Número } \\
\text { de } \\
\text { Arvores }\end{array}$ & Falha & Volume & (m3/ha) & Altura & $(\mathrm{cm})$ & $D A P Q$ & $\begin{array}{c}\text { CV } \\
\text { altura }\end{array}$ & $\begin{array}{l}\text { CV } \\
\text { DAP }\end{array}$ \\
\hline 1 & 28 & 13 & 0.144 & 210.75 & 18.66 & 13.51 & 14.16 & 21.90 & 32.15 \\
\hline 2 & 28 & 13 & 0.132 & 192.95 & 17.59 & 12.54 & 13.50 & 30.03 & 40.61 \\
\hline 3 & 24 & 25 & 0.153 & 190.67 & 19.46 & 14.32 & 14.61 & 13.47 & 20.47 \\
\hline 4 & 29 & 9 & 0.086 & 129.80 & 15.43 & 10.76 & 11.54 & 35.01 & 39.63 \\
\hline 5 & 28 & 13 & 0.113 & 165.04 & 17.39 & 12.10 & 12.78 & 28.62 & 34.76 \\
\hline 6 & 30 & 6 & 0.135 & 210.50 & 18.68 & 13.22 & 13.69 & 22.29 & 27.38 \\
\hline 7 & 24 & 25 & 0.075 & 94.27 & 15.94 & 9.92 & 10.62 & 29.52 & 39.08 \\
\hline 8 & 31 & 3 & 0.120 & 194.34 & 17.95 & 12.58 & 13.14 & 20.56 & 30.83 \\
\hline 9 & 29 & 9 & 0.135 & 203.51 & 19.05 & 13.35 & 13.72 & 18.11 & 24.31 \\
\hline 11 & 28 & 13 & 0.102 & 148.43 & 18.05 & 11.79 & 12.20 & 18.51 & 27.25 \\
\hline 12 & 30 & 6 & 0.143 & 224.05 & 18.38 & 13.74 & 14.27 & 21.24 & 28.49 \\
\hline 13 & 31 & 3 & 0.143 & 230.56 & 19.13 & 13.78 & 14.10 & 21.30 & 22.09 \\
\hline 14 & 26 & 19 & 0.166 & 224.22 & 18.56 & 14.34 & 15.02 & 26.77 & 31.95 \\
\hline 15 & 29 & 9 & 0.118 & 177.58 & 18.16 & 12.51 & 13.01 & 21.16 & 28.86 \\
\hline 17 & 29 & 9 & 0.111 & 167.13 & 17.36 & 11.89 & 12.53 & 29.18 & 34.02 \\
\hline 18 & 30 & 6 & 0.114 & 178.49 & 18.17 & 12.32 & 12.82 & 21.97 & 29.43 \\
\hline 19 & 28 & 13 & 0.136 & 198.09 & 18.41 & 13.38 & 13.93 & 17.83 & 29.40 \\
\hline 20 & 29 & 9 & 0.133 & 200.99 & 18.81 & 13.11 & 13.61 & 20.29 & 28.62 \\
\hline 21 & 30 & 6 & 0.148 & 231.32 & 19.50 & 13.78 & 14.23 & 16.24 & 26.07 \\
\hline 22 & 32 & 0 & 0.144 & 240.50 & 19.42 & 13.53 & 13.99 & 20.57 & 26.85 \\
\hline 23 & 29 & 9 & 0.095 & 143.74 & 15.74 & 11.03 & 11.93 & 35.10 & 42.00 \\
\hline 24 & 30 & 6 & 0.106 & 166.12 & 17.55 & 12.21 & 12.59 & 25.69 & 25.39 \\
\hline 25 & 30 & 6 & 0.150 & 234.69 & 18.97 & 13.87 & 14.40 & 21.47 & 28.40 \\
\hline 26 & 30 & 6 & 0.139 & 217.42 & 19.28 & 13.50 & 13.87 & 18.84 & 24.21 \\
\hline 27 & 31 & 3 & 0.151 & 243.71 & 19.77 & 13.69 & 14.20 & 19.28 & 27.98 \\
\hline 28 & 30 & 6 & 0.119 & 185.94 & 18.67 & 12.71 & 13.03 & 18.39 & 22.96 \\
\hline 29 & 31 & 3 & 0.119 & 192.48 & 18.26 & 12.50 & 13.03 & 22.34 & 30.14 \\
\hline 30 & 28 & 13 & 0.120 & 175.17 & 17.87 & 12.55 & 13.10 & 26.67 & 30.48 \\
\hline 31 & 30 & 6 & 0.138 & 215.43 & 19.30 & 13.39 & 13.80 & 15.89 & 25.21 \\
\hline
\end{tabular}




\begin{tabular}{lrrrrrrrrl}
32 & 30 & 6 & 0.126 & 197.59 & 19.02 & 12.67 & 13.21 & 20.77 & 30.04 \\
33 & 25 & 22 & 0.136 & 176.84 & 17.76 & 13.10 & 13.83 & 26.60 & 34.55 \\
34 & 30 & 6 & 0.146 & 227.85 & 19.32 & 13.56 & 14.02 & 23.28 & 26.70 \\
35 & 29 & 9 & 0.131 & 197.68 & 18.50 & 13.07 & 13.61 & 21.62 & 29.61 \\
36 & 30 & 6 & 0.131 & 205.09 & 17.80 & 12.90 & 13.66 & 22.50 & 35.44 \\
37 & 32 & 0 & 0.135 & 224.61 & 18.70 & 13.30 & 13.76 & 20.81 & 27.02 \\
38 & 29 & 9 & 0.115 & 173.58 & 16.66 & 12.01 & 12.85 & 33.16 & 38.88 \\
39 & 28 & 13 & 0.132 & 192.99 & 19.18 & 13.35 & 13.70 & 14.49 & 23.76 \\
40 & 31 & 3 & 0.109 & 176.53 & 17.02 & 12.12 & 12.75 & 30.41 & 33.35 \\
41 & 30 & 6 & 0.089 & 138.95 & 16.27 & 10.75 & 11.46 & 32.82 & 37.59 \\
42 & 30 & 6 & 0.093 & 144.79 & 15.73 & 11.25 & 11.92 & 34.29 & 35.80 \\
43 & 32 & 0 & 0.130 & 216.18 & 17.69 & 12.81 & 13.54 & 28.91 & 34.85 \\
44 & 31 & 3 & 0.169 & 273.60 & 19.47 & 14.56 & 15.11 & 19.04 & 28.21 \\
45 & 32 & 0 & 0.135 & 224.73 & 18.33 & 13.12 & 13.76 & 22.40 & 32.06 \\
46 & 30 & 6 & 0.096 & 149.51 & 16.83 & 11.28 & 11.90 & 29.12 & 34.25 \\
47 & 31 & 3 & 0.146 & 236.56 & 19.10 & 13.19 & 13.94 & 25.05 & 34.71 \\
49 & 31 & 3 & 0.141 & 227.09 & 18.95 & 13.52 & 13.99 & 19.70 & 26.95 \\
50 & 30 & 6 & 0.137 & 213.96 & 18.17 & 13.05 & 13.81 & 26.81 & 35.20 \\
51 & 31 & 3 & 0.128 & 207.13 & 18.08 & 13.14 & 13.63 & 20.18 & 27.94 \\
52 & 30 & 6 & 0.140 & 218.92 & 19.23 & 13.56 & 13.93 & 18.57 & 23.76 \\
53 & 32 & 0 & 0.108 & 180.22 & 17.22 & 11.85 & 12.49 & 30.42 & 33.89 \\
54 & 30 & 6 & 0.139 & 216.82 & 18.48 & 12.97 & 13.76 & 24.63 & 36.20 \\
55 & 30 & 6 & 0.130 & 202.65 & 16.95 & 12.64 & 13.60 & 30.83 & 40.52 \\
56 & 30 & 6 & 0.094 & 147.58 & 17.30 & 11.31 & 12.08 & 22.82 & 33.02 \\
58 & 30 & 6 & 0.193 & 301.19 & 19.40 & 15.74 & 16.26 & 18.50 & 26.37 \\
59 & 29 & 9 & 0.102 & 154.24 & 17.38 & 11.65 & 12.23 & 22.65 & 32.75 \\
60 & 29 & 9 & 0.111 & 168.23 & 16.10 & 11.82 & 12.76 & 37.99 & 41.42 \\
\hline & & & & & & & & &
\end{tabular}


Tabela 47. Estatísticas básicas (descritivas) ao nível de progênie, aos 5 anos de idade, para o experimento 2. E. urophylla, Anhembi-SP.

\begin{tabular}{|c|c|c|c|c|c|c|c|c|c|}
\hline Progenie & Arvores & $\begin{array}{c}\text { Falha } \\
+ \text { Desb } \\
(\%)\end{array}$ & $\begin{array}{l}\text { Volume } \\
\text { (m3) }\end{array}$ & $\begin{array}{l}\text { Volume } \\
\text { (m3/há) }\end{array}$ & $\begin{array}{l}\text { Altura } \\
(\mathrm{m})\end{array}$ & $\begin{array}{l}\text { DAP } \\
(\mathrm{cm})\end{array}$ & $\begin{array}{c}D A P Q \\
(\mathrm{~cm})\end{array}$ & $\begin{array}{c}\text { CV } \\
\text { altura } \\
(\%)\end{array}$ & $\begin{array}{l}\text { CV } \\
\text { DAP } \\
(\%)\end{array}$ \\
\hline 1 & 15 & 53 & 0.271 & 212.08 & 22.30 & 18.27 & 18.45 & 8.12 & 14.72 \\
\hline 2 & 15 & 53 & 0.268 & 209.46 & 23.07 & 17.68 & 17.94 & 8.23 & 17.90 \\
\hline 3 & 20 & 38 & 0.212 & 220.86 & 22.02 & 16.22 & 16.40 & 7.64 & 15.50 \\
\hline 4 & 12 & 63 & 0.178 & 111.19 & 20.83 & 15.28 & 15.41 & 9.51 & 13.88 \\
\hline 5 & 17 & 47 & 0.194 & 171.94 & 21.97 & 15.73 & 15.77 & 6.15 & 7.40 \\
\hline 6 & 18 & 44 & 0.225 & 210.59 & 22.64 & 16.52 & 16.69 & 4.90 & 14.81 \\
\hline 7 & 7 & 78 & 0.207 & 75.43 & 22.71 & 15.82 & 15.97 & 6.46 & 14.45 \\
\hline 8 & 14 & 56 & 0.237 & 173.21 & 22.36 & 17.01 & 17.16 & 11.04 & 13.85 \\
\hline 9 & 19 & 41 & 0.213 & 211.24 & 22.32 & 16.23 & 16.37 & 6.30 & 13.15 \\
\hline 11 & 14 & 56 & 0.172 & 125.72 & 21.57 & 14.85 & 15.01 & 5.81 & 15.61 \\
\hline 12 & 18 & 44 & 0.234 & 219.24 & 21.61 & 17.14 & 17.32 & 8.38 & 15.24 \\
\hline 13 & 22 & 31 & 0.223 & 255.58 & 22.82 & 16.51 & 16.58 & 5.88 & 9.38 \\
\hline 14 & 18 & 44 & 0.269 & 252.15 & 22.56 & 18.00 & 18.21 & 7.13 & 15.81 \\
\hline 15 & 17 & 47 & 0.193 & 171.27 & 21.91 & 15.56 & 15.71 & 8.16 & 14.24 \\
\hline 17 & 13 & 59 & 0.229 & 155.13 & 23.23 & 16.53 & 16.65 & 4.78 & 12.49 \\
\hline 18 & 18 & 44 & 0.200 & 187.57 & 21.69 & 15.86 & 16.03 & 11.54 & 14.91 \\
\hline 19 & 15 & 53 & 0.240 & 187.71 & 22.03 & 16.96 & 17.31 & 8.72 & 21.17 \\
\hline 20 & 16 & 50 & 0.216 & 180.24 & 22.16 & 16.29 & 16.48 & 7.03 & 15.65 \\
\hline 21 & 21 & 34 & 0.235 & 257.32 & 22.52 & 16.90 & 17.09 & 7.54 & 15.44 \\
\hline 22 & 22 & 31 & 0.220 & 251.73 & 22.48 & 16.39 & 16.55 & 6.49 & 14.33 \\
\hline 23 & 11 & 66 & 0.215 & 123.42 & 21.77 & 16.47 & 16.66 & 5.27 & 16.01 \\
\hline 24 & 13 & 59 & 0.187 & 126.49 & 22.00 & 15.25 & 15.39 & 6.43 & 14.09 \\
\hline 25 & 19 & 41 & 0.241 & 238.84 & 22.82 & 17.02 & 17.22 & 5.76 & 15.60 \\
\hline 26 & 19 & 41 & 0.226 & 224.07 & 23.16 & 16.43 & 16.55 & 6.94 & 12.01 \\
\hline 27 & 23 & 28 & 0.229 & 274.85 & 22.52 & 16.66 & 16.85 & 7.32 & 15.50 \\
\hline 28 & 17 & 47 & 0.181 & 160.36 & 22.03 & 15.13 & 15.19 & 6.19 & 9.41 \\
\hline 29 & 16 & 50 & 0.219 & 182.28 & 22.19 & 16.49 & 16.63 & 6.98 & 13.26 \\
\hline 30 & 17 & 47 & 0.206 & 182.47 & 22.18 & 15.97 & 16.11 & 6.81 & 13.50 \\
\hline 31 & 17 & 47 & 0.238 & 210.96 & 22.82 & 16.78 & 17.03 & 7.90 & 17.93 \\
\hline 32 & 14 & 56 & 0.228 & 166.41 & 22.82 & 16.57 & 16.74 & 5.93 & 14.90 \\
\hline 33 & 12 & 63 & 0.270 & 168.77 & 22.83 & 17.90 & 18.10 & 9.49 & 15.41 \\
\hline 34 & 22 & 31 & 0.238 & 272.76 & 23.16 & 16.77 & 16.96 & 7.13 & 15.35 \\
\hline
\end{tabular}




\begin{tabular}{rlrlllllll}
35 & 17 & 47 & 0.230 & 203.58 & 22.91 & 16.68 & 16.80 & 6.09 & 12.48 \\
36 & 18 & 44 & 0.238 & 222.97 & 21.67 & 17.06 & 17.43 & 7.84 & 21.28 \\
37 & 20 & 38 & 0.217 & 225.89 & 22.15 & 16.38 & 16.53 & 6.35 & 14.26 \\
38 & 14 & 56 & 0.225 & 164.21 & 21.75 & 16.69 & 16.87 & 14.11 & 15.54 \\
39 & 18 & 44 & 0.208 & 194.92 & 21.86 & 16.06 & 16.31 & 6.41 & 18.17 \\
40 & 16 & 50 & 0.196 & 163.39 & 21.56 & 15.74 & 15.92 & 9.54 & 15.86 \\
41 & 13 & 59 & 0.178 & 120.43 & 21.85 & 14.89 & 15.06 & 9.45 & 16.05 \\
42 & 14 & 56 & 0.182 & 132.77 & 21.46 & 15.30 & 15.41 & 7.34 & 12.14 \\
43 & 23 & 28 & 0.204 & 244.05 & 21.74 & 15.92 & 16.12 & 8.88 & 16.59 \\
44 & 24 & 25 & 0.260 & 325.51 & 22.58 & 17.56 & 17.87 & 8.35 & 19.32 \\
45 & 19 & 41 & 0.227 & 224.19 & 21.92 & 16.64 & 16.93 & 7.14 & 19.46 \\
46 & 14 & 56 & 0.175 & 127.62 & 21.00 & 14.80 & 15.06 & 11.44 & 19.60 \\
47 & 17 & 47 & 0.268 & 237.69 & 23.41 & 17.88 & 17.97 & 3.87 & 10.23 \\
49 & 21 & 34 & 0.223 & 243.41 & 22.36 & 16.52 & 16.67 & 6.53 & 13.96 \\
50 & 21 & 34 & 0.218 & 239.02 & 21.95 & 16.51 & 16.65 & 8.18 & 13.61 \\
51 & 17 & 47 & 0.221 & 195.38 & 21.59 & 16.66 & 16.86 & 7.65 & 15.97 \\
52 & 22 & 31 & 0.210 & 240.69 & 22.25 & 16.18 & 16.28 & 5.92 & 11.45 \\
53 & 14 & 56 & 0.204 & 148.52 & 22.68 & 15.69 & 15.85 & 5.16 & 15.15 \\
54 & 22 & 31 & 0.225 & 257.81 & 22.27 & 16.51 & 16.77 & 6.74 & 18.41 \\
55 & 16 & 50 & 0.249 & 207.65 & 22.37 & 17.39 & 17.62 & 7.89 & 16.86 \\
56 & 15 & 53 & 0.197 & 153.88 & 21.53 & 15.85 & 16.01 & 6.65 & 14.54 \\
58 & 22 & 31 & 0.300 & 344.21 & 23.16 & 18.81 & 19.03 & 7.40 & 15.68 \\
59 & 12 & 63 & 0.213 & 133.41 & 22.12 & 16.31 & 16.44 & 5.02 & 13.00 \\
60 & 14 & 56 & 0.220 & 160.09 & 22.43 & 16.35 & 16.61 & 5.92 & 18.67 \\
\hline
\end{tabular}


Tabela 48. Estatísticas básicas (descritivas) ao nível de progênie, aos 6 anos de idade, para o experimento 2. E. urophylla, Anhembi-SP.

\begin{tabular}{|c|c|c|c|c|c|c|c|c|c|}
\hline $\begin{array}{c}\text { FSJ } 6 \\
\text { Progenie }\end{array}$ & $\begin{array}{l}\text { Número } \\
\text { Arvores }\end{array}$ & $\begin{array}{c}\text { Falha } \\
+ \text { Desb } \\
(\%)\end{array}$ & $\begin{array}{l}\text { Volume } \\
\text { (m3) }\end{array}$ & $\begin{array}{l}\text { Volume } \\
\text { (m3/ há) }\end{array}$ & $\begin{array}{c}\text { Altura } \\
\text { (m) }\end{array}$ & $\begin{array}{l}\text { DAP } \\
(\mathrm{cm})\end{array}$ & $D A P Q$ & $\begin{array}{c}\text { CV } \\
\text { altura } \\
(\%)\end{array}$ & $\begin{array}{l}\text { CV } \\
\text { DAP } \\
(\%)\end{array}$ \\
\hline 1 & 14 & 56 & 0.354 & 258.32 & 24.86 & 19.74 & 19.97 & 6.94 & 16.18 \\
\hline 2 & 14 & 56 & 0.328 & 238.91 & 25.25 & 18.64 & 18.95 & 8.61 & 18.78 \\
\hline 3 & 19 & 41 & 0.254 & 250.95 & 24.32 & 16.85 & 17.05 & 6.72 & 15.71 \\
\hline 4 & 12 & 63 & 0.216 & 135.12 & 22.75 & 16.07 & 16.22 & 10.87 & 14.09 \\
\hline 5 & 13 & 59 & 0.240 & 162.62 & 24.23 & 16.63 & 16.68 & 8.70 & 8.64 \\
\hline 6 & 15 & 53 & 0.280 & 218.78 & 24.40 & 17.61 & 17.84 & 8.06 & 16.80 \\
\hline 7 & 6 & 81 & 0.254 & 79.35 & 24.17 & 16.87 & 17.04 & 9.76 & 15.65 \\
\hline 8 & 14 & 56 & 0.294 & 214.25 & 24.71 & 17.96 & 18.14 & 11.41 & 14.53 \\
\hline 9 & 19 & 41 & 0.272 & 269.12 & 25.00 & 17.27 & 17.44 & 5.42 & 14.19 \\
\hline 11 & 11 & 66 & 0.233 & 133.43 & 23.77 & 16.38 & 16.53 & 6.12 & 14.32 \\
\hline 12 & 18 & 44 & 0.289 & 270.58 & 23.69 & 18.20 & 18.42 & 6.91 & 16.30 \\
\hline 13 & 20 & 38 & 0.277 & 288.09 & 24.85 & 17.55 & 17.65 & 7.06 & 10.50 \\
\hline 14 & 18 & 44 & 0.339 & 317.97 & 24.72 & 19.22 & 19.49 & 8.36 & 17.29 \\
\hline 15 & 17 & 47 & 0.242 & 214.05 & 23.91 & 16.61 & 16.78 & 7.62 & 14.96 \\
\hline 17 & 10 & 69 & 0.303 & 157.76 & 25.60 & 17.92 & 18.14 & 7.12 & 16.39 \\
\hline 18 & 16 & 50 & 0.235 & 195.70 & 23.56 & 16.39 & 16.61 & 12.71 & 16.97 \\
\hline 19 & 14 & 56 & 0.311 & 226.49 & 24.11 & 18.51 & 18.85 & 8.14 & 20.00 \\
\hline 20 & 15 & 53 & 0.276 & 215.94 & 24.40 & 17.59 & 17.80 & 8.35 & 15.99 \\
\hline 21 & 20 & 38 & 0.296 & 308.90 & 25.17 & 17.92 & 18.14 & 5.59 & 16.26 \\
\hline 22 & 18 & 44 & 0.279 & 261.17 & 24.94 & 17.60 & 17.72 & 4.86 & 12.33 \\
\hline 23 & 10 & 69 & 0.270 & 140.62 & 23.90 & 17.44 & 17.68 & 8.18 & 17.39 \\
\hline 24 & 12 & 63 & 0.214 & 134.07 & 23.58 & 15.84 & 15.99 & 4.59 & 14.50 \\
\hline 25 & 17 & 47 & 0.300 & 265.42 & 24.76 & 18.12 & 18.37 & 6.51 & 16.92 \\
\hline 26 & 17 & 47 & 0.282 & 249.63 & 25.29 & 17.47 & 17.63 & 6.10 & 14.05 \\
\hline 27 & 20 & 38 & 0.278 & 289.68 & 24.77 & 17.44 & 17.66 & 7.48 & 16.17 \\
\hline 28 & 17 & 47 & 0.218 & 192.99 & 23.74 & 16.01 & 16.07 & 6.19 & 9.16 \\
\hline 29 & 14 & 56 & 0.274 & 199.94 & 24.18 & 17.62 & 17.79 & 6.91 & 14.60 \\
\hline 30 & 16 & 50 & 0.255 & 212.86 & 24.53 & 16.91 & 17.07 & 5.49 & 14.22 \\
\hline 31 & 16 & 50 & 0.264 & 220.12 & 24.69 & 17.15 & 17.32 & 6.27 & 14.52 \\
\hline 32 & 14 & 56 & 0.284 & 207.32 & 25.21 & 17.60 & 17.76 & 6.31 & 14.09 \\
\hline 33 & 11 & 66 & 0.319 & 182.64 & 24.55 & 18.75 & 18.98 & 8.12 & 16.54 \\
\hline 34 & 22 & 31 & 0.306 & 350.84 & 25.48 & 18.09 & 18.31 & 6.59 & 16.04 \\
\hline
\end{tabular}




\begin{tabular}{rrrrrrrrrr}
35 & 16 & 50 & 0.283 & 236.24 & 24.97 & 17.73 & 17.87 & 4.48 & 13.11 \\
36 & 17 & 47 & 0.310 & 274.26 & 24.26 & 18.29 & 18.71 & 9.33 & 22.19 \\
37 & 17 & 47 & 0.269 & 238.13 & 23.94 & 17.49 & 17.66 & 7.63 & 14.61 \\
38 & 11 & 66 & 0.327 & 187.50 & 25.36 & 18.75 & 18.93 & 10.17 & 14.53 \\
39 & 17 & 47 & 0.274 & 242.71 & 24.59 & 17.26 & 17.58 & 8.11 & 19.67 \\
40 & 14 & 56 & 0.231 & 168.79 & 23.11 & 16.42 & 16.64 & 9.90 & 17.39 \\
41 & 12 & 63 & 0.204 & 127.27 & 23.33 & 15.41 & 15.56 & 11.82 & 14.48 \\
42 & 13 & 59 & 0.227 & 153.60 & 23.65 & 16.31 & 16.40 & 5.68 & 11.19 \\
43 & 20 & 38 & 0.261 & 271.53 & 23.85 & 17.06 & 17.34 & 9.60 & 18.65 \\
44 & 23 & 28 & 0.322 & 386.30 & 25.00 & 18.52 & 18.87 & 8.11 & 20.16 \\
45 & 16 & 50 & 0.297 & 247.69 & 24.28 & 17.92 & 18.31 & 9.60 & 21.56 \\
46 & 13 & 59 & 0.209 & 141.53 & 22.46 & 15.52 & 15.84 & 13.34 & 21.06 \\
47 & 17 & 47 & 0.336 & 297.45 & 25.94 & 19.02 & 19.10 & 4.36 & 9.29 \\
49 & 20 & 38 & 0.276 & 287.87 & 24.52 & 17.54 & 17.71 & 7.01 & 14.49 \\
50 & 19 & 41 & 0.261 & 258.36 & 24.21 & 17.16 & 17.33 & 7.77 & 14.56 \\
51 & 14 & 56 & 0.260 & 189.51 & 23.68 & 17.26 & 17.46 & 7.25 & 16.13 \\
52 & 21 & 34 & 0.253 & 276.33 & 24.45 & 16.90 & 17.02 & 6.62 & 12.03 \\
53 & 13 & 59 & 0.236 & 160.04 & 24.35 & 16.26 & 16.45 & 6.24 & 16.23 \\
54 & 22 & 31 & 0.284 & 325.17 & 24.61 & 17.55 & 17.84 & 9.34 & 18.78 \\
55 & 15 & 53 & 0.304 & 237.62 & 24.57 & 18.25 & 18.54 & 6.87 & 18.40 \\
56 & 14 & 56 & 0.255 & 186.15 & 23.61 & 17.14 & 17.36 & 6.50 & 16.48 \\
58 & 20 & 38 & 0.390 & 406.55 & 25.37 & 20.44 & 20.70 & 7.09 & 16.57 \\
59 & 11 & 66 & 0.266 & 152.52 & 24.50 & 17.30 & 17.44 & 5.84 & 13.09 \\
60 & 14 & 56 & 0.282 & 205.72 & 24.57 & 17.51 & 17.84 & 5.86 & 20.43 \\
\hline & & & & & & & & &
\end{tabular}


Tabela 49 - Frequência de árvores normais, falhas de plantio, mortas e bifurcadas, aos 4 anos de idade, para o experimento 2. E. urophylla, Anhembi-SP.

\begin{tabular}{lcccc}
\hline \multicolumn{1}{c}{ Categoria } & F.A.S. & F.A.A. & F.R.S. & F.R.A. \\
& $($ arv $)$ & $($ arv $)$ & $(\%)$ & $(\%)$ \\
\hline NORMAL & 1610 & 1610 & 89.8 & 89.8 \\
FALHA & 123 & 1733 & 6.9 & 96.7 \\
MORTA & 12 & 1745 & 0.7 & 97.4 \\
QUEBRADA & 19 & 1764 & 1.1 & 98.4 \\
BIFURCADA & 23 & 1787 & 1.3 & 99.7 \\
BIFURCADA & 05 & 1792 & 0.3 & 100.0 \\
ACIMA DO DAP & & & & \\
\hline
\end{tabular}

Onde:
F.A.S. = frequência absoluta simples
F.R.S. = frequência relativa simples
F.A.A = frequência absoluta acumulada
F.R.A. = frequência relativa acumulada

Os dados acima demonstram a plena normalidade das condições experimentais, que apresentam-se equivalentes às dos melhores plantios de eucalipto da região. 


\begin{abstract}
ANEXO 2:
LISTAGENS COM CLASSIFICAÇÃO DAS PROGÊNIES PELO TESTE REGWF
\end{abstract}

e gráficos de volume por progênie Antes e após desbaste 
Tabela 50: Classificação das progênies pelo diâmetro (DAP), aos 3 anos de idade, para o experimento 1: Europhylla, Bofete-SP, 1994.

\begin{tabular}{|c|c|c|c|c|c|c|}
\hline \multicolumn{7}{|c|}{ Prog. No } \\
\hline \multirow[t]{2}{*}{26} & 14.15 & $A$ & & & & \\
\hline & & A & 13 & 11.64 & $A$ & $B$ \\
\hline \multirow[t]{2}{*}{22} & 13.61 & $A \quad B$ & & & $A$ & B \\
\hline & & $A \quad B$ & 17 & 11.53 & A & $B$ \\
\hline \multirow[t]{2}{*}{27} & 13.02 & $A \quad B$ & & & $A$ & B \\
\hline & & $A \quad B$ & 31 & 11.40 & $A$ & B \\
\hline \multirow[t]{2}{*}{2} & 12.86 & $A \quad B$ & & & A & B \\
\hline & & $A \quad B$ & 7 & 11.28 & A & B \\
\hline \multirow[t]{2}{*}{6} & 12.40 & $A \quad B$ & & & A & $B$ \\
\hline & & $A \quad B$ & 8 & 11.28 & $A$ & $B$ \\
\hline \multirow[t]{2}{*}{3} & 12.27 & $A \quad B$ & & & $A$ & B \\
\hline & & $A \quad B$ & 29 & 11.14 & $A$ & B \\
\hline \multirow[t]{2}{*}{32} & 12.25 & $A \quad B$ & & & A & B \\
\hline & & $A \quad B$ & 21 & 11.11 & $A$ & B \\
\hline \multirow[t]{2}{*}{10} & 12.15 & $A \quad B$ & & & A & B \\
\hline & & $A \quad B$ & 15 & 11.00 & A & B \\
\hline \multirow[t]{2}{*}{9} & 12.13 & $A \quad B$ & & & $A$ & B \\
\hline & & $A \quad B$ & 23 & 10.98 & A & B \\
\hline \multirow[t]{2}{*}{4} & 12.07 & $A \quad B$ & & & A & B \\
\hline & & $A \quad B$ & 19 & 10.96 & $A$ & $B$ \\
\hline \multirow[t]{2}{*}{20} & 12.04 & $A \quad B$ & & & A & B \\
\hline & & $A \quad B$ & 14 & 10.92 & A & B \\
\hline \multirow[t]{2}{*}{16} & 11.92 & $A \quad B$ & & & A & $B$ \\
\hline & & $A \quad B$ & 24 & 10.90 & A & B \\
\hline \multirow[t]{2}{*}{28} & 11.90 & $A \quad B$ & & & $A$ & B \\
\hline & & $A \quad B$ & 25 & 10.79 & $A$ & $B$ \\
\hline \multirow[t]{2}{*}{30} & 11.79 & $A \quad B$ & & & & B \\
\hline & & $A \quad B$ & 12 & 10.78 & & B \\
\hline \multirow[t]{2}{*}{11} & 11.75 & $A \quad B$ & & & & $B$ \\
\hline & & $A \quad B$ & 5 & 10.45 & & B \\
\hline \multirow[t]{2}{*}{1} & 11.70 & $A \quad B$ & & & & B \\
\hline & & A B & 18 & 10.35 & & B \\
\hline 33 & 11.65 & $A \quad B$ & & & & \\
\hline
\end{tabular}


Tabela 51 : Classificação das progênies pelo diâmetro (DAP), aos 5 anos de idade, para o experimento 1: E urophylla, Bofete-SP, 1996.

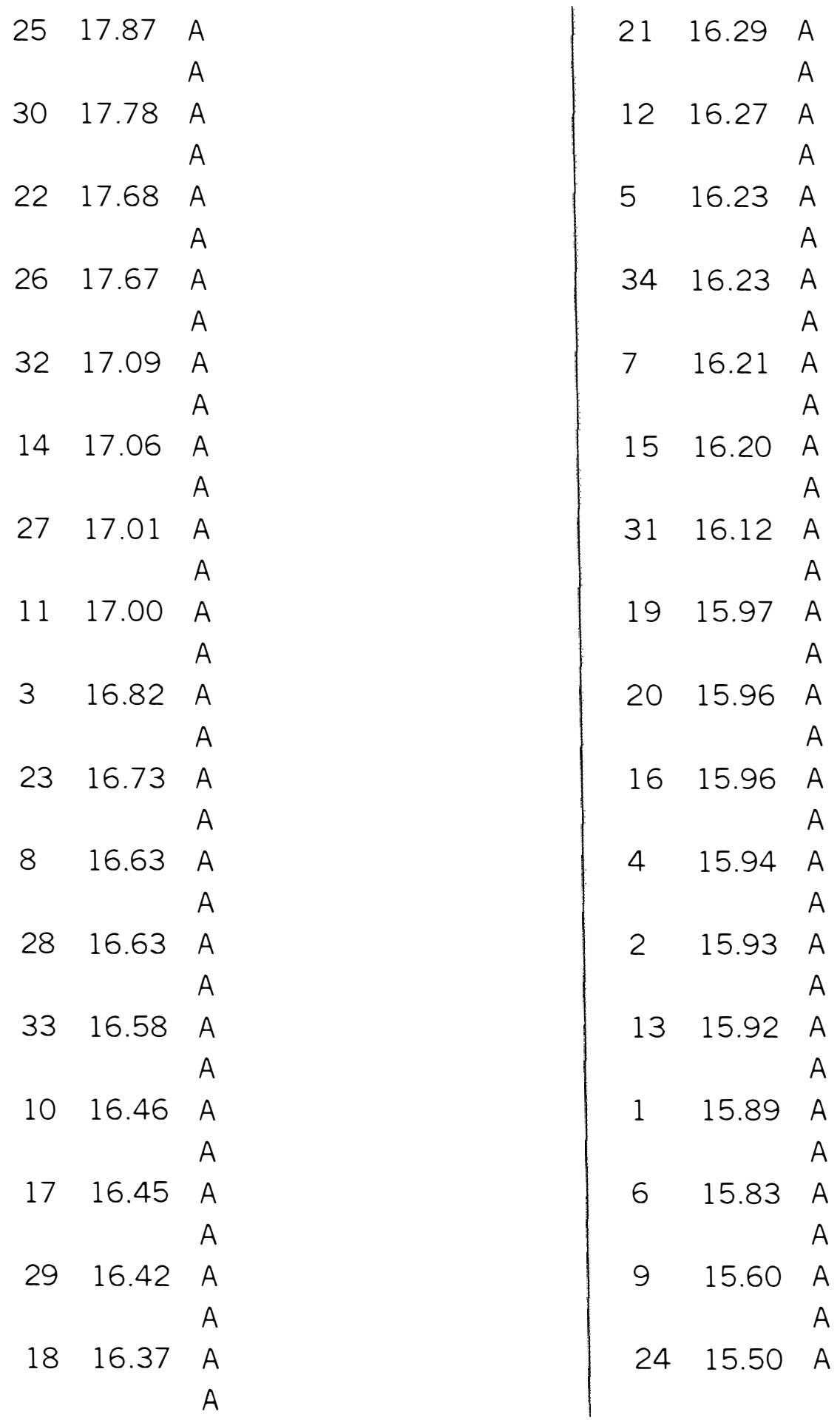


Tabela 52: Classificação das progênies pelo volume real com casca $\left(\mathrm{m}^{3} / \mathrm{ha}\right)$, aos 3 anos de idade, para o experimento 1: E urophylla, Bofete-SP, 1994.

\begin{tabular}{|c|c|c|c|c|}
\hline 26 & 0.125 & $\begin{array}{l}A \\
A\end{array}$ & 1 & 0.079 \\
\hline 22 & 0.114 & $\begin{array}{ll}A & B \\
A & B\end{array}$ & 33 & 0.078 \\
\hline 27 & 0.107 & $\begin{array}{ll}A & B \\
A & B\end{array}$ & 31 & 0.078 \\
\hline 32 & 0.095 & $\begin{array}{ll}A & B \\
A & B\end{array}$ & 13 & 0.075 \\
\hline 2 & 0.095 & $\begin{array}{ll}A & B \\
A & B\end{array}$ & 25 & 0.075 \\
\hline 6 & 0.087 & $\begin{array}{ll}A & B \\
A & B\end{array}$ & 7 & 0.074 \\
\hline 3 & 0.087 & $\begin{array}{ll}A & B \\
A & B\end{array}$ & 24 & 0.073 \\
\hline 20 & 0.087 & $\begin{array}{ll}A & B \\
A & B\end{array}$ & 8 & 0.072 \\
\hline 30 & 0.085 & $\begin{array}{ll}A & B \\
A & B\end{array}$ & 19 & 0.072 \\
\hline 10 & 0.083 & $\begin{array}{ll}A & B \\
& B\end{array}$ & 15 & 0.071 \\
\hline 16 & 0.082 & $\begin{array}{l}B \\
B\end{array}$ & 29 & 0.071 \\
\hline 11 & 0.082 & $\begin{array}{l}B \\
B\end{array}$ & 14 & 0.070 \\
\hline 28 & 0.082 & $\begin{array}{l}B \\
B\end{array}$ & 23 & 0.070 \\
\hline 9 & 0.082 & $\begin{array}{l}B \\
B\end{array}$ & 21 & 0.068 \\
\hline 4 & 0.081 & $\begin{array}{l}B \\
B\end{array}$ & 18 & 0.067 \\
\hline 17 & 0.079 & $\begin{array}{l}B \\
B\end{array}$ & 12 & 0.065 \\
\hline 34 & 0.079 & $\begin{array}{l}B \\
B\end{array}$ & 5 & 0.064 \\
\hline
\end{tabular}


Tabela 53: Classificação das progênies por volume real com casca $\left(\mathrm{m}^{3} / \mathrm{ha}\right)$, aos 5 anos de idade, para o experimento 1: E urophylla, Bofete-SP, 1994.

\begin{tabular}{|c|c|c|c|c|}
\hline 25 & 0.248 & $\begin{array}{l}A \\
A\end{array}$ & 18 & 0.191 \\
\hline 26 & 0.243 & $\begin{array}{l}A \\
A\end{array}$ & 31 & 0.191 \\
\hline 22 & 0.239 & $\begin{array}{l}A \\
A\end{array}$ & 16 & 0.190 \\
\hline 30 & 0.233 & $\begin{array}{l}A \\
A\end{array}$ & 15 & 0.190 \\
\hline 32 & 0.227 & $\begin{array}{l}A \\
A\end{array}$ & 20 & 0.190 \\
\hline 27 & 0.220 & $\begin{array}{l}A \\
A\end{array}$ & 7 & 0.189 \\
\hline 11 & 0.214 & $\begin{array}{l}A \\
A\end{array}$ & 5 & 0.188 \\
\hline 3 & 0.214 & $\begin{array}{l}A \\
A\end{array}$ & 21 & 0.187 \\
\hline 23 & 0.210 & $\begin{array}{l}A \\
A\end{array}$ & 2 & 0.184 \\
\hline 14 & 0.207 & $\begin{array}{l}A \\
A\end{array}$ & 19 & 0.183 \\
\hline 33 & 0.205 & $\begin{array}{l}A \\
A\end{array}$ & 34 & 0.181 \\
\hline 8 & 0.203 & $\begin{array}{l}A \\
A\end{array}$ & 13 & 0.179 \\
\hline 28 & 0.201 & $\begin{array}{l}A \\
A\end{array}$ & 24 & 0.178 \\
\hline 12 & 0.197 & $\begin{array}{l}A \\
A\end{array}$ & 4 & 0.177 \\
\hline 10 & 0.196 & $\begin{array}{l}A \\
A\end{array}$ & 6 & 0.176 \\
\hline 17 & 0.194 & $\begin{array}{l}A \\
A\end{array}$ & 1 & 0.174 \\
\hline 29 & 0.194 & $\begin{array}{l}A \\
A\end{array}$ & 9 & 0.171 \\
\hline
\end{tabular}


Tabela 54 : Classificação das progênies pelo diâmetro (DAP), aos 4 anos de idade, para o experimento 2: E urophylla, Anhembi - SP, 1994.

\begin{tabular}{|c|c|c|c|c|c|c|c|c|c|c|c|c|c|}
\hline \multirow[t]{2}{*}{58} & 15.74 & A & & & & & 54 & 12.97 & A & B & C & D & $E$ \\
\hline & & A & & & & & & & A & B & C & D & $E$ \\
\hline \multirow[t]{2}{*}{3} & 14.32 & A & B & & & & 36 & 12.90 & A & B & C & D & $E$ \\
\hline & & A & B & & & & & & A & B & C & D & $E$ \\
\hline \multirow[t]{2}{*}{44} & 14.56 & A & B & C & & & 43 & 12.81 & A & B & C & D & $\mathrm{E}$ \\
\hline & & A & B & C & & & & & A & B & C & D & $E$ \\
\hline \multirow[t]{2}{*}{14} & 14.34 & A & B & C & & & 28 & 12.71 & A & B & C & D & $E$ \\
\hline & & A & B & C & & & & & A & B & C & D & $E$ \\
\hline \multirow[t]{2}{*}{25} & 13.87 & A & B & C & D & & 32 & 12.67 & A & B & C & D & $E$ \\
\hline & & A & B & C & D & & & & A & B & C & D & $E$ \\
\hline \multirow[t]{2}{*}{13} & 13.78 & A & B & C & D & & 55 & 12.64 & A & B & C & D & $E$ \\
\hline & & A & B & C & D & & & & A & B & C & D & $E$ \\
\hline \multirow[t]{2}{*}{21} & 13.18 & A & B & C & D & & 29 & 12.50 & A & B & C & D & $E$ \\
\hline & & A & B & C & D & & & & A & B & C & D & $E$ \\
\hline \multirow[t]{2}{*}{12} & 13.74 & A & B & C & D & & 8 & 12.58 & A & B & C & D & $E$ \\
\hline & & A & B & C & D & & & & A & B & C & D & $E$ \\
\hline \multirow[t]{2}{*}{27} & 13.69 & A & B & C & D & & 30 & 12.55 & A & B & C & D & $\mathrm{E}$ \\
\hline & & A & B & C & D & & & & A & B & C & D & $\mathrm{E}$ \\
\hline \multirow[t]{2}{*}{52} & 13.56 & A & B & C & D & & 2 & 12.54 & A & B & C & D & $E$ \\
\hline & & A & B & C & D & & & & A & B & C & D & $E$ \\
\hline \multirow[t]{2}{*}{39} & 13.35 & A & B & C & D & & 15 & 12.51 & A & B & C & D & $E$ \\
\hline & & A & B & C & D & & & & A & B & C & D & $E$ \\
\hline \multirow[t]{2}{*}{19} & 13.38 & A & B & C & D & & 40 & 12.12 & A & B & C & D & $E$ \\
\hline & & A & B & C & D & & & & A & B & C & D & $E$ \\
\hline \multirow[t]{2}{*}{22} & 13.53 & A & B & C & D & & 24 & 12.21 & A & B & C & D & E \\
\hline & & A & B & C & D & & & & A & B & C & D & $E$ \\
\hline \multirow[t]{2}{*}{49} & 13.52 & A & B & C & D & E & 38 & 12.01 & A & B & C & D & $E$ \\
\hline & & A & B & C & D & $\mathrm{E}$ & & & A & B & C & D & $E$ \\
\hline \multirow{2}{*}{1} & 73.51 & A & B & C & D & E & 5 & 12.10 & A & B & C & D & $E$ \\
\hline & & A & B & C & D & E & & & A & B & C & D & $E$ \\
\hline 34 & 13.56 & A & B & C & D & E & 18 & 12.32 & A & B & C & D & $E$ \\
\hline & & A & B & C & D & $\mathrm{E}$ & & & A & B & C & D & $E$ \\
\hline 26 & 13.50 & A & B & C & D & E & 60 & 11.82 & A & B & C & D & $E$ \\
\hline & & A & B & C & D & E & & & A & B & C & D & $E$ \\
\hline 31 & 13.39 & A & B & C & D & E & 17 & 11.89 & A & B & C & D & $E$ \\
\hline & & A & B & C & D & $\mathrm{E}$ & & & A & B & C & D & $E$ \\
\hline 6 & 13.22 & A & B & C & D & E & 53 & 11.85 & A & B & C & D & $E$ \\
\hline & & A & B & C & D & E & & & A & B & C & D & $E$ \\
\hline 9 & 13.35 & A & B & C & D & E & 59 & 11.65 & A & B & C & D & $E$ \\
\hline & & A & B & C & D & $\mathrm{E}$ & & & A & B & C & D & $E$ \\
\hline 37 & 13.30 & A & B & C & D & E & 11 & 11.79 & A & B & C & D & $E$ \\
\hline & & A & B & C & D & E & & & A & B & C & D & $E$ \\
\hline 47 & 13.19 & A & B & C & D & E & 42 & 11.25 & A & B & C & D & $E$ \\
\hline & & A & B & C & D & E & & & A & B & C & D & $E$ \\
\hline 51 & 13.14 & A & B & C & D & E & 46 & 11.28 & A & B & C & D & $E$ \\
\hline & & A & B & C & D & E & & & & B & C & D & $E$ \\
\hline 33 & 13.10 & A & B & C & D & E & 56 & 11.31 & & B & C & D & $E$ \\
\hline & & A & B & C & D & $\mathrm{E}$ & & & & B & C & D & $E$ \\
\hline 45 & 13.12 & A & B & C & D & E & 23 & 11.03 & & B & C & D & $E$ \\
\hline & & A & B & C & D & $\mathrm{E}$ & & & & & C & D & $\mathrm{E}$ \\
\hline 20 & 13.11 & A & B & C & D & E & 41 & 10.75 & & & C & D & $E$ \\
\hline & & A & B & C & D & E & & & & & & D & E \\
\hline 35 & 13.07 & $A$ & B & C & D & $\mathrm{E}$ & 4 & 10.76 & & & & D & $E$ \\
\hline 50 & 1305 & A & B & C & D & E & & & & & & & $E$ \\
\hline 5 & 10.00 & A & $B$ & C & D & $\mathrm{E}$ & 7 & 9.92 & & & & & $E$ \\
\hline
\end{tabular}


Tabela 55 : Classificação das progênies pelo diâmetro (DAP), aos 6 anos de idade, para o experimento 2: E urophylla, Anhembi - SP, 1994.

\begin{tabular}{|c|c|c|c|c|c|c|}
\hline 58 & 20.44 & $A$ & & & & \\
\hline \multirow{2}{*}{1} & 19.74 & A & B & & & \\
\hline & & $A$ & $B$ & & & \\
\hline \multirow[t]{2}{*}{14} & 19.22 & $A$ & $B$ & $C$ & & \\
\hline & & A & B & C & & \\
\hline \multirow[t]{2}{*}{47} & 19.02 & $A$ & $B$ & $C$ & $D$ & \\
\hline & & $A$ & $B$ & $C$ & $D$ & \\
\hline \multirow[t]{2}{*}{33} & 18.75 & A & B & C & D & \\
\hline & & A & B & C & D & \\
\hline \multirow[t]{2}{*}{2} & 18.64 & A & B & C & D & $E$ \\
\hline & & $A$ & $B$ & $C$ & D & $E$ \\
\hline \multirow[t]{2}{*}{44} & 18.52 & $A$ & B & $C$ & $D$ & $E$ \\
\hline & & $A$ & $B$ & C & $D$ & $E$ \\
\hline \multirow[t]{2}{*}{19} & 18.51 & $A$ & $B$ & $C$ & $D$ & $E$ \\
\hline & & $A$ & B & $c$ & $D$ & $E$ \\
\hline \multirow[t]{2}{*}{38} & 18.75 & $A$ & B & $c$ & $D$ & $E$ \\
\hline & & $A$ & $B$ & $c$ & $D$ & $E$ \\
\hline \multirow[t]{2}{*}{36} & 18.29 & $A$ & B & $c$ & $D$ & $E$ \\
\hline & & $A$ & $B$ & C & $D$ & $E$ \\
\hline \multirow[t]{2}{*}{55} & 18.25 & $A$ & $B$ & C & D & $E$ \\
\hline & & $A$ & $B$ & C & $D$ & $\bar{E}$ \\
\hline \multirow[t]{2}{*}{12} & 18.20 & $A$ & $B$ & $C$ & $D$ & E \\
\hline & & $A$ & $B$ & $C$ & $D$ & E \\
\hline \multirow[t]{2}{*}{25} & 18.12 & $A$ & B & C & $D$ & $E$ \\
\hline & & $A$ & $B$ & $c$ & $D$ & E \\
\hline \multirow[t]{2}{*}{34} & 18.09 & $A$ & B & C & D & $E$ \\
\hline & & $A$ & $B$ & $c$ & $D$ & $E$ \\
\hline \multirow[t]{2}{*}{8} & 17.96 & $A$ & B & $C$ & $D$ & $E$ \\
\hline & & $A$ & B & C & $D$ & E \\
\hline \multirow[t]{2}{*}{21} & 17.92 & $A$ & B & C & $D$ & $E$ \\
\hline & & $A$ & $B$ & $C$ & $D$ & $E$ \\
\hline \multirow[t]{2}{*}{17} & 17.92 & $A$ & $B$ & C & $D$ & $E$ \\
\hline & & $A$ & $B$ & $C$ & $D$ & $E$ \\
\hline \multirow[t]{2}{*}{35} & 17.73 & $A$ & $B$ & $C$ & $D$ & $E$ \\
\hline & & $A$ & $B$ & $c$ & $D$ & $E$ \\
\hline 51 & 17.26 & $A$ & $B$ & $c$ & $D$ & $E$ \\
\hline & & $A$ & $B$ & $C$ & $D$ & $E$ \\
\hline 6 & 17.61 & $A$ & $B$ & C & $D$ & $E$ \\
\hline & & $A$ & B & C & $D$ & $E$ \\
\hline 45 & 17.92 & $A$ & $B$ & $C$ & $D$ & $E$ \\
\hline & & $A$ & B & $C$ & $D$ & $E$ \\
\hline 27 & 17.44 & A & $B$ & C & $D$ & $E$ \\
\hline & & $A$ & $B$ & C & $D$ & $E$ \\
\hline 32 & 17.60 & $A$ & $B$ & $C$ & $D$ & $E$ \\
\hline & & $A$ & $B$ & C & $D$ & $E$ \\
\hline 13 & 17.55 & $A$ & $B$ & C & $D$ & $E$ \\
\hline & & $A$ & B & $C$ & $D$ & $E$ \\
\hline 54 & 17.55 & $A$ & $B$ & C & $D$ & $E$ \\
\hline & & $A$ & B & C & $D$ & $\mathrm{E}$ \\
\hline 49 & 17.54 & $A$ & B & $C$ & $D$ & $E$ \\
\hline & & $A$ & $B$ & C & $D$ & $E$ \\
\hline 60 & 17.51 & $A$ & B & $C$ & $D$ & E \\
\hline & & $A$ & $B$ & $c$ & $D$ & E \\
\hline 26 & 17.47 & $A$ & $B$ & $c$ & $D$ & $E$ \\
\hline & & $A$ & $B$ & $C$ & $D$ & $E$ \\
\hline
\end{tabular}

\begin{tabular}{|c|c|c|c|c|c|}
\hline \multirow[t]{2}{*}{23} & \multirow[t]{2}{*}{17.44} & A & B & C & D \\
\hline & & A & B & C & D \\
\hline \multirow[t]{2}{*}{29} & \multirow[t]{2}{*}{17.62} & $A$ & B & C & $D$ \\
\hline & & $A$ & B & C & $D$ \\
\hline \multirow[t]{2}{*}{20} & \multirow[t]{2}{*}{17.59} & A & $B$ & C & $D$ \\
\hline & & A & B & C & $\mathrm{D}$ \\
\hline \multirow[t]{2}{*}{37} & \multirow[t]{2}{*}{17.49} & A & $B$ & C & D \\
\hline & & $A$ & B & C & $D$ \\
\hline \multirow[t]{2}{*}{22} & \multirow[t]{2}{*}{17.60} & A & B & C & D \\
\hline & & A & B & $c$ & $D$ \\
\hline \multirow[t]{2}{*}{59} & \multirow[t]{2}{*}{17.30} & $A$ & $B$ & $c$ & $D$ \\
\hline & & $A$ & B & C & $D$ \\
\hline \multirow[t]{2}{*}{9} & \multirow[t]{2}{*}{17.27} & $A$ & $B$ & $C$ & $D$ \\
\hline & & $A$ & B & C & D \\
\hline \multirow[t]{2}{*}{39} & \multirow[t]{2}{*}{17.26} & $A$ & B & C & $D$ \\
\hline & & $A$ & B & C & $D$ \\
\hline \multirow[t]{2}{*}{50} & \multirow{2}{*}{17.16} & A & B & C & D \\
\hline & & $A$ & $B$ & C & $D$ \\
\hline \multirow[t]{2}{*}{31} & \multirow[t]{2}{*}{17.15} & A & B & C & D \\
\hline & & A & B & C & D \\
\hline 56 & 17.14 & $A$ & B & C & $D$ \\
\hline & & A & B & C & D \\
\hline 7 & 16.87 & $A$ & B & C & $D$ \\
\hline & & $A$ & B & C & $D$ \\
\hline 43 & 17.06 & A & B & C & D \\
\hline & & $A$ & $B$ & $C$ & $D$ \\
\hline 52 & 16.90 & $A$ & $B$ & C & $D$ \\
\hline & & A & $B$ & $C$ & $D$ \\
\hline 3 & 16.85 & A & $B$ & $C$ & $D$ \\
\hline & & A & B & $c$ & $D$ \\
\hline 30 & 16.91 & A & B & C & $D$ \\
\hline & & A & $B$ & C & $D$ \\
\hline 5 & 16.63 & A & B & C & D \\
\hline & & $A$ & B & $C$ & $D$ \\
\hline 15 & 16.61 & $A$ & $B$ & $C$ & $D$ \\
\hline & & A & B & $C$ & $D$ \\
\hline 40 & 16.42 & A & B & C & $D$ \\
\hline & & & $B$ & $c$ & $D$ \\
\hline 53 & 16.26 & & $B$ & $c$ & $D$ \\
\hline & & & $B$ & $c$ & $D$ \\
\hline 18 & 16.39 & & $B$ & C & $D$ \\
\hline & & & $B$ & C & $D$ \\
\hline 42 & 16.31 & & B & C & D \\
\hline & & & B & $C$ & D \\
\hline 4 & 16.07 & & B & C & D \\
\hline & & & B & $C$ & $D$ \\
\hline 28 & 16.01 & & B & C & $D$ \\
\hline & & & & $C$ & $D$ \\
\hline 24 & 15.84 & & & C & $D$ \\
\hline & & & & C & D \\
\hline 11 & 16.38 & & & $C$ & $D$ \\
\hline 46 & 15.52 & & & & $\begin{array}{l}D \\
D\end{array}$ \\
\hline 41 & 15.41 & & & & \\
\hline
\end{tabular}


Tabela 56 : Classificação das progênies por volume real com casca $\left(\mathrm{m}^{3} / \mathrm{ha}\right)$, aos 4 anos de idade, para o experimento 2: E urophylla, Anhembi - SP, 1994.

\begin{tabular}{|c|c|c|c|c|c|}
\hline 58 & 0.193 & A & & & \\
\hline 44 & 0.169 & A & $\begin{array}{l}\mathrm{B} \\
\mathrm{B}\end{array}$ & & \\
\hline 3 & 0.153 & $\begin{array}{l}A \\
A\end{array}$ & & $\begin{array}{l}\text { C } \\
\text { C }\end{array}$ & \\
\hline 14 & 0.166 & $\begin{array}{l}A \\
A\end{array}$ & & $\begin{array}{l}C \\
C\end{array}$ & $\begin{array}{l}\mathrm{D} \\
\mathrm{D}\end{array}$ \\
\hline 27 & 0.151 & $\begin{array}{l}A \\
A\end{array}$ & $\begin{array}{l}\mathrm{B} \\
\mathrm{B}\end{array}$ & $\begin{array}{l}\mathrm{C} \\
\mathrm{C}\end{array}$ & $\begin{array}{l}\text { D } \\
\text { D }\end{array}$ \\
\hline 25 & 0.150 & $\begin{array}{l}A \\
A\end{array}$ & $\begin{array}{l}B \\
B\end{array}$ & $\begin{array}{l}\mathrm{C} \\
\mathrm{C}\end{array}$ & $\begin{array}{l}\mathrm{D} \\
\mathrm{D}\end{array}$ \\
\hline 47 & 0.146 & $\begin{array}{l}A \\
A\end{array}$ & & $\begin{array}{l}C \\
C\end{array}$ & $\begin{array}{l}\mathrm{D} \\
\mathrm{D}\end{array}$ \\
\hline 21 & 0.148 & $\begin{array}{l}A \\
A\end{array}$ & $\begin{array}{l}\mathrm{B} \\
\mathrm{B}\end{array}$ & $\begin{array}{l}\mathrm{C} \\
\mathrm{C}\end{array}$ & $\begin{array}{l}\mathrm{D} \\
\mathrm{D}\end{array}$ \\
\hline 22 & 0.144 & $\begin{array}{l}A \\
A\end{array}$ & $\begin{array}{l}B \\
B\end{array}$ & $\begin{array}{l}C \\
C\end{array}$ & $\begin{array}{l}\mathrm{D} \\
\mathrm{D}\end{array}$ \\
\hline 34 & 0.146 & $\begin{array}{l}A \\
A\end{array}$ & $\begin{array}{l}\mathrm{B} \\
\mathrm{B}\end{array}$ & $\begin{array}{l}C \\
C\end{array}$ & $\begin{array}{l}D \\
D\end{array}$ \\
\hline 12 & 0.143 & $\begin{array}{l}A \\
A\end{array}$ & $\begin{array}{l}\mathrm{B} \\
\mathrm{B}\end{array}$ & $\begin{array}{l}C \\
C\end{array}$ & $\begin{array}{l}\text { D } \\
\text { D }\end{array}$ \\
\hline 13 & 0.143 & $\begin{array}{l}A \\
A\end{array}$ & $\begin{array}{l}\mathrm{B} \\
\mathrm{B}\end{array}$ & $\begin{array}{l}\text { C } \\
C\end{array}$ & $\begin{array}{l}\mathrm{D} \\
\mathrm{D}\end{array}$ \\
\hline 1 & 0.144 & & & $\begin{array}{l}C \\
C\end{array}$ & $\begin{array}{l}D \\
D\end{array}$ \\
\hline 49 & 0.141 & $\begin{array}{l}A \\
A\end{array}$ & $\begin{array}{l}\mathrm{B} \\
\mathrm{B}\end{array}$ & $\begin{array}{l}C \\
C\end{array}$ & $\begin{array}{l}\mathrm{D} \\
\mathrm{D}\end{array}$ \\
\hline 52 & 0.140 & $\begin{array}{l}A \\
A\end{array}$ & $\begin{array}{l}\mathrm{B} \\
\mathrm{B}\end{array}$ & $\begin{array}{l}C \\
C\end{array}$ & $\begin{array}{l}\mathrm{D} \\
\mathrm{D}\end{array}$ \\
\hline 54 & 0.139 & $\begin{array}{l}A \\
A\end{array}$ & & $\begin{array}{l}C \\
C\end{array}$ & $\begin{array}{l}D \\
D\end{array}$ \\
\hline 26 & 0.139 & $\begin{array}{l}A \\
A\end{array}$ & $\begin{array}{l}\mathrm{B} \\
\mathrm{B}\end{array}$ & $\begin{array}{l}c \\
c\end{array}$ & $\begin{array}{l}D \\
D\end{array}$ \\
\hline 6 & 0.135 & $\begin{array}{l}A \\
A\end{array}$ & $\begin{array}{l}\mathrm{B} \\
\mathrm{B}\end{array}$ & $\begin{array}{l}C \\
C\end{array}$ & $\begin{array}{l}D \\
D\end{array}$ \\
\hline 39 & 0.132 & $\begin{array}{l}A \\
A\end{array}$ & $\begin{array}{l}\mathrm{B} \\
\mathrm{B}\end{array}$ & $\begin{array}{l}C \\
C\end{array}$ & $\begin{array}{l}D \\
D\end{array}$ \\
\hline 31 & 0.138 & $\begin{array}{l}A \\
A\end{array}$ & $\begin{array}{l}\mathrm{B} \\
\mathrm{B}\end{array}$ & $\begin{array}{l}\mathrm{C} \\
\mathrm{C}\end{array}$ & $\begin{array}{l}\mathrm{D} \\
\mathrm{D}\end{array}$ \\
\hline 33 & 0.136 & $\begin{array}{l}A \\
A\end{array}$ & $\begin{array}{l}B \\
B\end{array}$ & $\begin{array}{l}C \\
C\end{array}$ & $\begin{array}{l}D \\
D\end{array}$ \\
\hline 45 & 0.135 & $\begin{array}{l}A \\
A\end{array}$ & $\begin{array}{l}B \\
B\end{array}$ & $\begin{array}{l}C \\
C\end{array}$ & $\begin{array}{l}D \\
D\end{array}$ \\
\hline 37 & 0.135 & $\begin{array}{l}A \\
A\end{array}$ & $\begin{array}{l}B \\
B\end{array}$ & $\begin{array}{l}\mathrm{C} \\
\mathrm{C}\end{array}$ & $\begin{array}{l}\mathrm{D} \\
\mathrm{D}\end{array}$ \\
\hline 50 & 0.137 & $\begin{array}{l}A \\
A\end{array}$ & $\begin{array}{l}B \\
B\end{array}$ & $\begin{array}{l}C \\
C\end{array}$ & $\begin{array}{l}D \\
D\end{array}$ \\
\hline 19 & 0.136 & $\begin{array}{l}A \\
A\end{array}$ & $\begin{array}{l}\mathrm{B} \\
\mathrm{B}\end{array}$ & $\begin{array}{l}\mathrm{C} \\
\mathrm{C}\end{array}$ & $\begin{array}{l}\mathrm{D} \\
\mathrm{D}\end{array}$ \\
\hline 20 & 0.133 & $\begin{array}{l}A \\
A\end{array}$ & $\begin{array}{l}B \\
B\end{array}$ & $\begin{array}{l}\mathrm{C} \\
\mathrm{C}\end{array}$ & $\begin{array}{l}\mathrm{D} \\
\mathrm{D}\end{array}$ \\
\hline 2 & 0.132 & $\begin{array}{l}A \\
A\end{array}$ & $\begin{array}{l}\mathrm{B} \\
\mathrm{B}\end{array}$ & $\begin{array}{l}\mathrm{C} \\
\mathrm{C}\end{array}$ & $\begin{array}{l}\mathrm{D} \\
\mathrm{D}\end{array}$ \\
\hline 9 & 0.135 & $\begin{array}{l}A \\
A\end{array}$ & $\begin{array}{l}\mathrm{B} \\
\mathrm{B}\end{array}$ & $\begin{array}{l}\mathrm{C} \\
\mathrm{C}\end{array}$ & $\begin{array}{l}\mathrm{D} \\
\mathrm{D}\end{array}$ \\
\hline
\end{tabular}

\begin{tabular}{|c|c|c|c|c|c|}
\hline 35 & 0.131 & A & B C & C & D \\
\hline & & A & B & C & D \\
\hline 36 & 0.131 & $\begin{array}{l}A \\
A\end{array}$ & $\begin{array}{l}B \\
B\end{array}$ & $\begin{array}{l}\mathrm{C} \\
\mathrm{C}\end{array}$ & $\begin{array}{l}\text { D } \\
\text { D }\end{array}$ \\
\hline 43 & 0.130 & A & B & C & $\mathrm{D}$ \\
\hline 55 & 0130 & A & B & C & \\
\hline 50 & 0.730 & $\begin{array}{l}A \\
A\end{array}$ & $B$ & c & D \\
\hline 32 & 0.126 & A & $B$ & C & D \\
\hline & & A & B & C & D \\
\hline 51. & 0.128 & $\begin{array}{l}A \\
A\end{array}$ & $\begin{array}{l}\text { B } \\
\text { B }\end{array}$ & $\begin{array}{l}\mathrm{C} \\
\mathrm{C}\end{array}$ & $\begin{array}{l}\mathrm{D} \\
\mathrm{D}\end{array}$ \\
\hline 29 & 0.119 & A & B & C & $\mathrm{D}$ \\
\hline 8 & 0.120 & A & B & C & D \\
\hline & & $\begin{array}{l}\mathrm{A} \\
\mathrm{A}\end{array}$ & $\begin{array}{l}B \\
B\end{array}$ & $\begin{array}{l}\mathrm{c} \\
\mathrm{C}\end{array}$ & $\begin{array}{l}\text { D } \\
\text { D }\end{array}$ \\
\hline 30 & 0.120 & A & B & C & $\mathrm{D}$ \\
\hline 28 & 0.119 & $\begin{array}{l}A \\
A\end{array}$ & B & C & $\mathrm{D}$ \\
\hline & & $\begin{array}{l}A \\
A\end{array}$ & $\begin{array}{l}\text { B } \\
\text { B }\end{array}$ & $\begin{array}{l}\mathrm{C} \\
\mathrm{C}\end{array}$ & $\begin{array}{l}\mathrm{D} \\
\mathrm{D}\end{array}$ \\
\hline 15 & 0.118 & A & B & C & D \\
\hline 38 & 0.115 & $\begin{array}{l}A \\
A\end{array}$ & B & $\mathrm{C}$ & D \\
\hline 18 & & $\hat{A}$ & B & $\mathrm{c}$ & $\begin{array}{l}\text { D } \\
\text { D }\end{array}$ \\
\hline & & $\begin{array}{l}A \\
A\end{array}$ & $\begin{array}{l}B \\
B\end{array}$ & $\begin{array}{l}C \\
C\end{array}$ & $\begin{array}{l}\text { D } \\
\text { D }\end{array}$ \\
\hline 40 & 0.109 & A & B & C & D \\
\hline 24 & & A & B & C & D \\
\hline & 0.106 & $\begin{array}{l}\text { A } \\
A\end{array}$ & $\begin{array}{l}\mathrm{B} \\
\mathrm{B}\end{array}$ & $\begin{array}{l}\text { C } \\
C\end{array}$ & $\begin{array}{l}D \\
D\end{array}$ \\
\hline 5 & 0.113 & A & B & C & D \\
\hline 17 & 0.111 & A & B & C & $\mathrm{D}$ \\
\hline & & A & $\begin{array}{l}B \\
B\end{array}$ & $\begin{array}{l}c \\
c\end{array}$ & $\mathrm{D}$ \\
\hline 60 & 0.111 & $\begin{array}{l}A \\
A\end{array}$ & $\begin{array}{l}B \\
B\end{array}$ & $\begin{array}{l}\mathrm{C} \\
\mathrm{C}\end{array}$ & $\begin{array}{l}\mathrm{D} \\
\mathrm{D}\end{array}$ \\
\hline 53 & 0.108 & A & B & C & D \\
\hline & & A & B & C & D \\
\hline 59 & 0.102 & $\begin{array}{l}A \\
A\end{array}$ & $\begin{array}{l}B \\
B\end{array}$ & C & D \\
\hline 46 & 0.096 & A & B & c & D \\
\hline 42 & 0.093 & $\begin{array}{l}A \\
A\end{array}$ & $\begin{array}{l}B \\
B\end{array}$ & $\begin{array}{l}C \\
C\end{array}$ & $\begin{array}{l}D \\
D\end{array}$ \\
\hline & & & B & C & D \\
\hline 11 & 0.102 & & B & C & $\mathrm{D}$ \\
\hline 23 & 0.095 & & B & C & D \\
\hline 56 & 0.094 & & & $c$ & D \\
\hline 41 & 0.089 & & & & D \\
\hline 4 & 0.086 & & & & \\
\hline 7 & 0.075 & & & & \\
\hline
\end{tabular}


Tabela 57 : Classificação das progênies por volume real com casca $\left(\mathrm{m}^{3} / \mathrm{ha}\right)$, aos 6 anos de idade, para o experimento 2: E urophylla, Anhembi - SP, 1996.

\begin{tabular}{|c|c|c|c|c|c|c|c|}
\hline 58 & 0.390 & A & & & & & \\
\hline 1 & 0.354 & $\begin{array}{l}A \\
A\end{array}$ & B & & & & \\
\hline & & $A$ & B & & & & \\
\hline 14 & 0.339 & A & B & C & & & \\
\hline & & A & B & C & & & \\
\hline 47 & 0.336 & A & B & C & D & & \\
\hline & & A & B & C & D & & \\
\hline 44 & 0.322 & A & B & C & D & $E$ & \\
\hline & & A & B & C & D & E & \\
\hline 33 & 0.319 & A & B & C & D & $E$ & \\
\hline & & A & B & C & D & $E$ & $\mathrm{~F}$ \\
\hline 2 & 0.328 & A & B & C & D & $E$ & $\mathrm{~F}$ \\
\hline & & A & $B$ & C & D & $E$ & $\mathrm{~F}$ \\
\hline 36 & 0.310 & A & B & C & D & $E$ & \\
\hline & & A & B & C & D & $\mathrm{E}$ & \\
\hline 19 & 0.311 & A & B & C & D & E & \\
\hline & & A & $B$ & C & D & $E$ & \\
\hline 38 & 0.327 & A & B & C & D & $E$ & \\
\hline & & A & $B$ & C & $D$ & $E$ & \\
\hline 34 & 0.306 & $A$ & $B$ & C & $D$ & $E$ & \\
\hline & & $A$ & $B$ & $C$ & $D$ & $E$ & \\
\hline 55 & 0.304 & $A$ & $B$ & C & $D$ & $E$ & \\
\hline & & A & B & C & D & $E$ & \\
\hline 17 & 0.303 & A & B & C & D & $E$ & \\
\hline & & A & B & C & $D$ & $E$ & \\
\hline 25 & 0.300 & A & B & C & $D$ & $E$ & \\
\hline & & A & B & C & $D$ & $E$ & \\
\hline 21 & 0.296 & $A$ & $B$ & C & $D$ & E & \\
\hline & & A & $B$ & $c$ & $D$ & $E$ & \\
\hline 8 & 0.294 & A & B & C & $D$ & $E$ & \\
\hline & & A & B & C & $D$ & $E$ & \\
\hline 12 & 0.289 & A & $B$ & C & D & $E$ & \\
\hline & & A & B & C & D & $E$ & \\
\hline 54 & 0.284 & A & B & C & D & $E$ & \\
\hline & & A & $B$ & $C$ & $D$ & $E$ & \\
\hline 35 & 0.283 & A & B & C & $D$ & $E$ & \\
\hline & & A & B & $C$ & $D$ & $E$ & \\
\hline 32 & 0.284 & A & $B$ & C & $D$ & E & \\
\hline & & $A$ & $B$ & $C$ & $D$ & $\mathrm{E}$ & \\
\hline 60 & 0.282 & A & $B$ & C & $D$ & $E$ & \\
\hline & & $A$ & B & C & D & $E$ & \\
\hline 26 & 0.282 & $A$ & B & C & $D$ & $E$ & \\
\hline & & $A$ & B & C & $D$ & $E$ & \\
\hline 27 & 0.278 & $A$ & B & C & $D$ & $E$ & \\
\hline & & $A$ & B & $C$ & $D$ & $E$ & \\
\hline 13 & 0.277 & $A$ & B & $C$ & $D$ & $E$ & \\
\hline & & A & B & $C$ & $D$ & $E$ & \\
\hline 49 & 0.276 & $A$ & $B$ & C & $D$ & $E$ & \\
\hline & & $A$ & B & C & $D$ & $E$ & \\
\hline 45 & 0.297 & A & B & C & $D$ & $E$ & \\
\hline & & $A$ & $B$ & $C$ & $D$ & $E$ & \\
\hline 39 & 0.274 & $A$ & B & C & $D$ & $E$ & \\
\hline & & $A$ & B & $C$ & $D$ & $E$ & \\
\hline 51 & 0.260 & $A$ & B & C & $D$ & $E$ & \\
\hline & & $A$ & $B$ & $C$ & $D$ & $E$ & \\
\hline
\end{tabular}

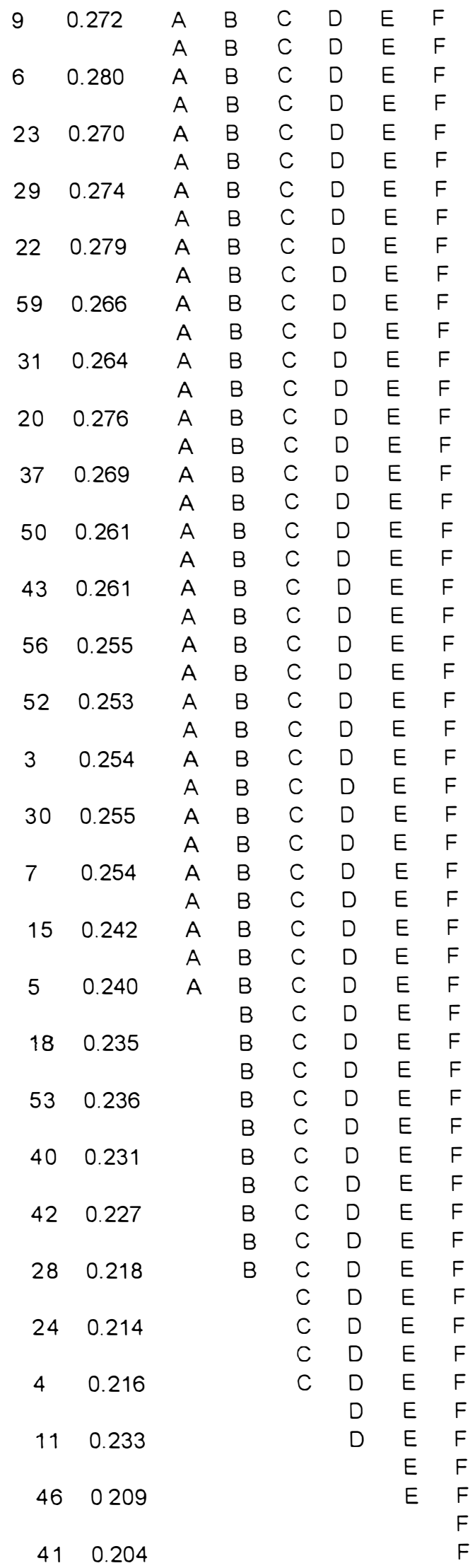


Experimento 1 - Bofete - SP

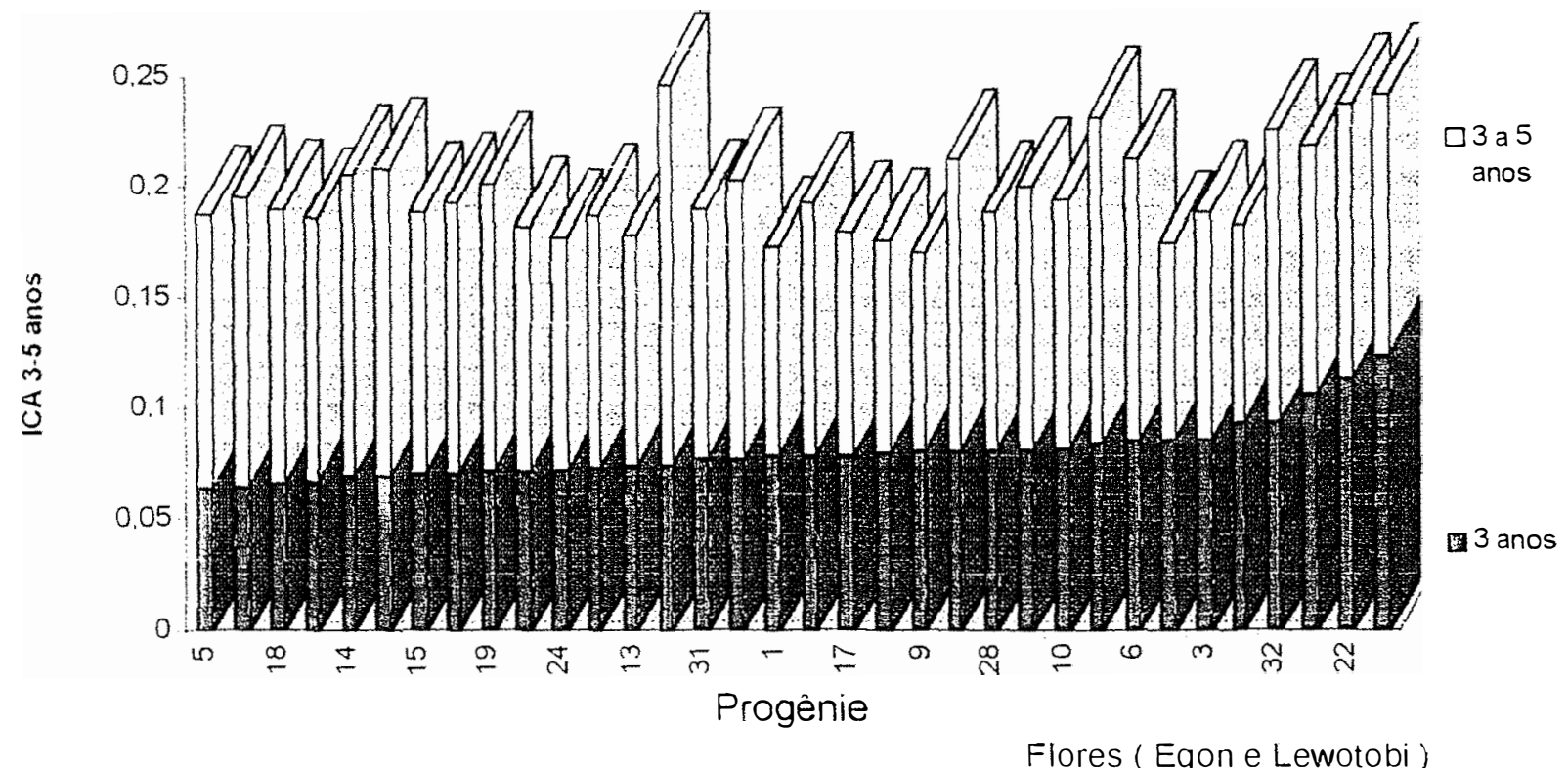

Experimento 2 - Anhembi-SP

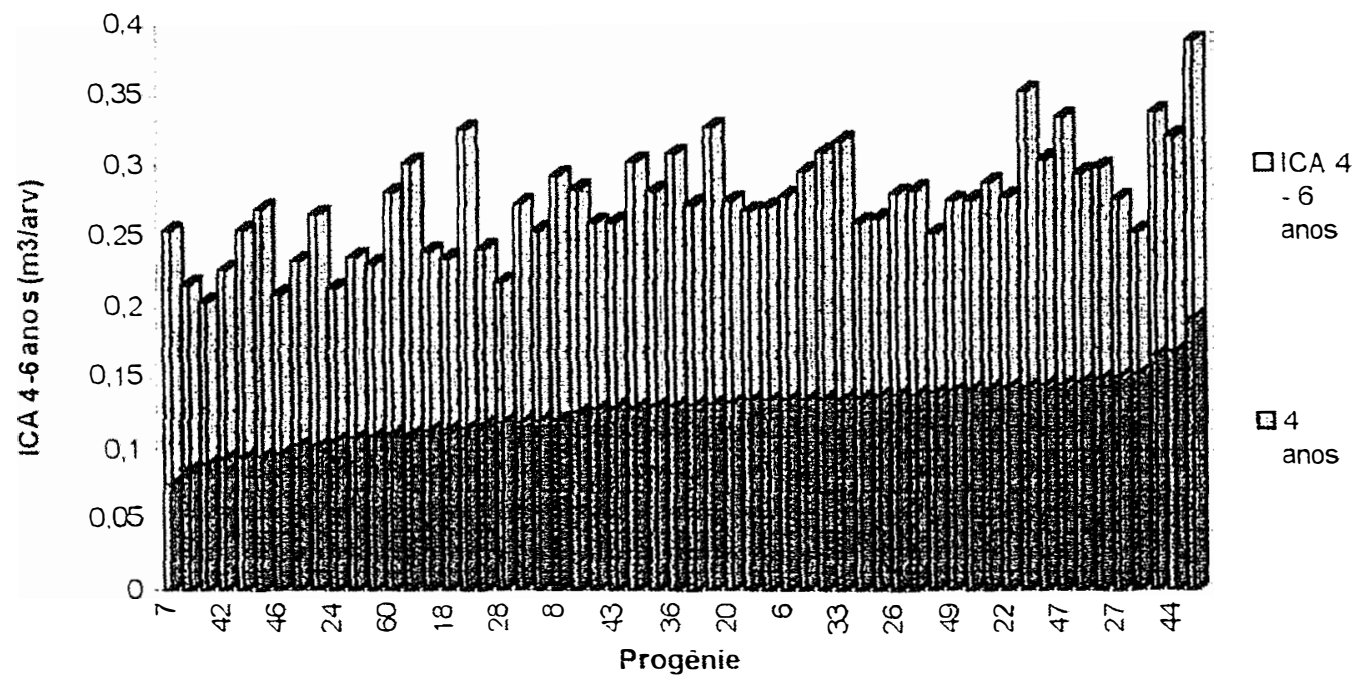

Outras Ilhas

Gráficos com a distribuição de volume por progênie. antes e após o desbaste. para as duas Populações $F 0$ e $F 1$ de $E$. urophylla. evidenciando a resposta diferenciada por progênie. 


\section{ANEXO 03:}

\section{Resumo da análise confirmatória para os dados dos dois experimentos}

objetivo desta análise confirmatória foi testar as assunções de:

a) Distribuição normal das médias das parcelas;

b) Homocedasticidade entre as variâncias dos tratamentos.

As demais assunções exigidas pela análise de variância e pelos testes de comparação de médias foram consideradas como satisfeitas. Os resultados completos obtidos estão nas tabelas do anexo 2 , para cada experimento.

Tabela 58 - Resultados dos testes de normalidade e de homogeneidade de variâncias obtidos a partir dos dados originais, para o experimento 1 ( $\left.F_{0}\right)$.

\begin{tabular}{cccccc}
\hline Procedência & Variável & $\begin{array}{c}\text { Transformação } \\
\text { Utilizada }\end{array}$ & $\begin{array}{c}\text { Prob } \\
>\text { W }\end{array}$ & b & Prob \\
& Altura $(\mathrm{m})$ & Nenhuma & 0.0586 & -0.358 & 0.9587 \\
\hline \multirow{3}{*}{ Mt. Egon } & DAP $(\mathrm{cm})$ & Nenhuma & 0.1478 & 4.064 & 0.5766 \\
& Volume $\left(\mathrm{m}^{3} / \mathrm{arv}\right)$ & Nenhuma & 0.0123 & 1.266 & 0.6677 \\
\hline \multirow{3}{*}{ Mt. Lewotobi } & Altura $(\mathrm{m})$ & Nenhuma & 0.7217 & -13.638 & 0.0550 \\
& DAP $(\mathrm{cm})$ & Nenhuma & 0.8580 & -4.517 & 0.7304 \\
& Volume $\left(\mathrm{m}^{3} / a r v\right)$ & Nenhuma & 0.6236 & -0.797 & 0.7595 \\
\hline
\end{tabular}

onde:

Prob $<W=$ Resultado do Teste de Normalidade de Shapiro \& Wilk;

$\mathrm{b}=$ Coeficiente angular do teste de Box \& Cox, para testar Heterocedasticidade;

Prob $>|T|=$ Resultado do Teste t pareado, para verificar se o valor obtido para $b$ é igual a 0 ; In = Logaritmo neperiano (base e).

Os resultados resumidos na tabela 01 permitem verificar que, originalmente, os dados das variáveis DAP, altura e volume estimado por árvore apresentaram distribuição normal e homocedasticidade, satisfazendo as premissas exigidas pela análise de variância. 
Tabela 59 - Resultados dos testes de normalidade e de homogeneidade de variâncias obtidos a partir dos dados originais, para o experimento 2 ( F1).

\begin{tabular}{ccccc}
\hline Variável & $\begin{array}{c}\text { Transformação } \\
\text { Utilizada }\end{array}$ & Prob $>\mathrm{W}$ & $\mathrm{b}$ & Prob $>|\mathrm{T}|$ \\
\hline Altura $(\mathrm{m})$ & Nenhuma & 0.0001 & -6.84 & 0.0007 \\
DAP $(\mathrm{cm})$ & Nenhuma & 0.6751 & +2.14 & 0.1608 \\
$\begin{array}{c}\text { Volume } \\
\left(\mathrm{m}^{3} / \mathrm{arv}\right)\end{array}$ & Nenhuma & 0.0001 & +1.93 & 0.0031 \\
Altura $(\mathrm{m})$ & 4a potência & 0.2655 & +0.54 & 0.3270 \\
DAP $(\mathrm{cm})$ & Nenhuma & 0.6751 & +2.14 & 0.1608 \\
$\begin{array}{l}\text { Volume } \\
\left(\mathrm{m}^{3} / \mathrm{arv}\right)\end{array}$ & raiz quadrada & 0.5948 & +0.76 & 0.5440 \\
\hline
\end{tabular}

onde :

Prob $<W=$ Resultado do Teste de Normalidade de Shapiro \& Wilk;

$\mathrm{b}$ = Coeficiente angular do teste de Box \& Cox, para testar Homocedasticidade;

Prob $>|T|=$ Resultado do Teste t pareado, para verificar se o valor obtido para b é igual a 0 ; In = Logaritmo neperiano (base e $)$.

A partir dos resultados resumidos na tabela 02 , pode-se verificar que originalmente os dados das variáveis altura e volume por árvore não apresentaram distribuição normal e homocedasticidade.

Após transformar estatisticamente a altura pela quarta potência, e o volume por árvore pela raiz quadrada, foi possivel observar para todas as variáveis estudadas uma distribuição normal e homocedasticidade, atendendendo assim às premissas para as análises de variância. 


\section{APÊNDICE 1}

\section{INFORMAÇÕES SOBRE AS POPULAÇÕES NATURAIS \\ DE E. urophylla}

Mapas, fotos e figuras

( compilado e modificado de Martin \& Cossalter, 1975 e 1976, em Bois et Forêts des Tropiques, $\mathrm{n}^{\mathrm{os}} 163$ a 166 ) 


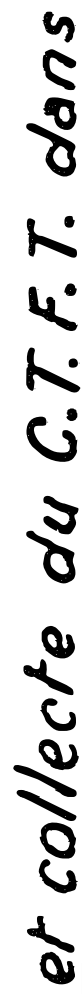

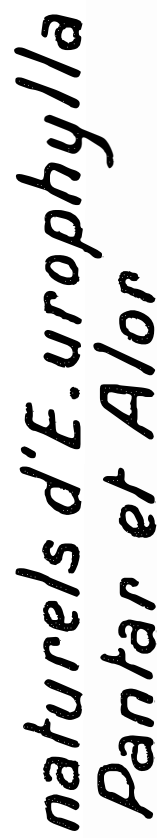

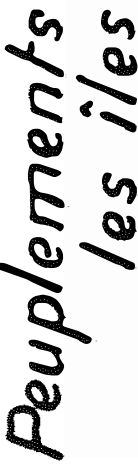

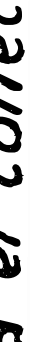

(2)

हो

है

5

iष

0

s

(2)

的

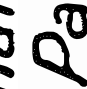

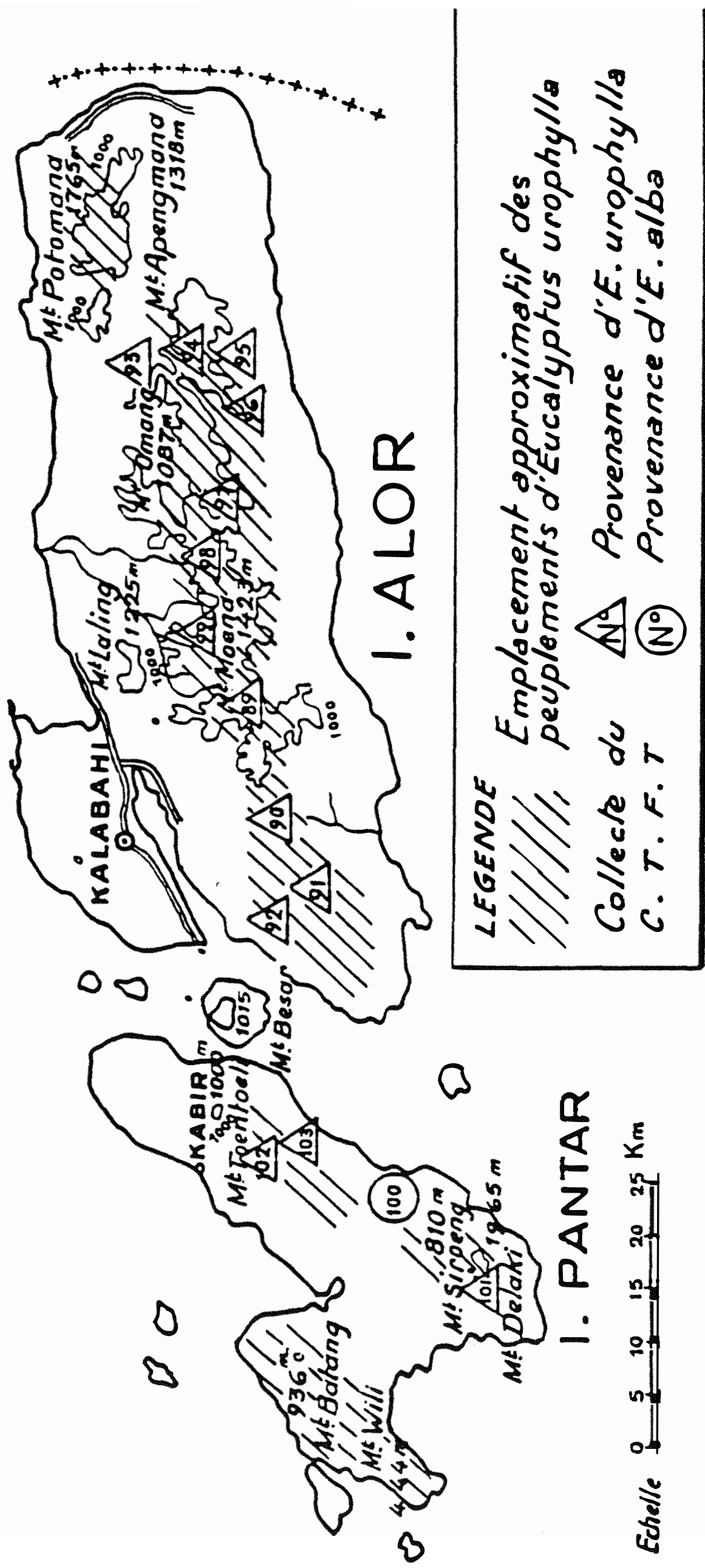




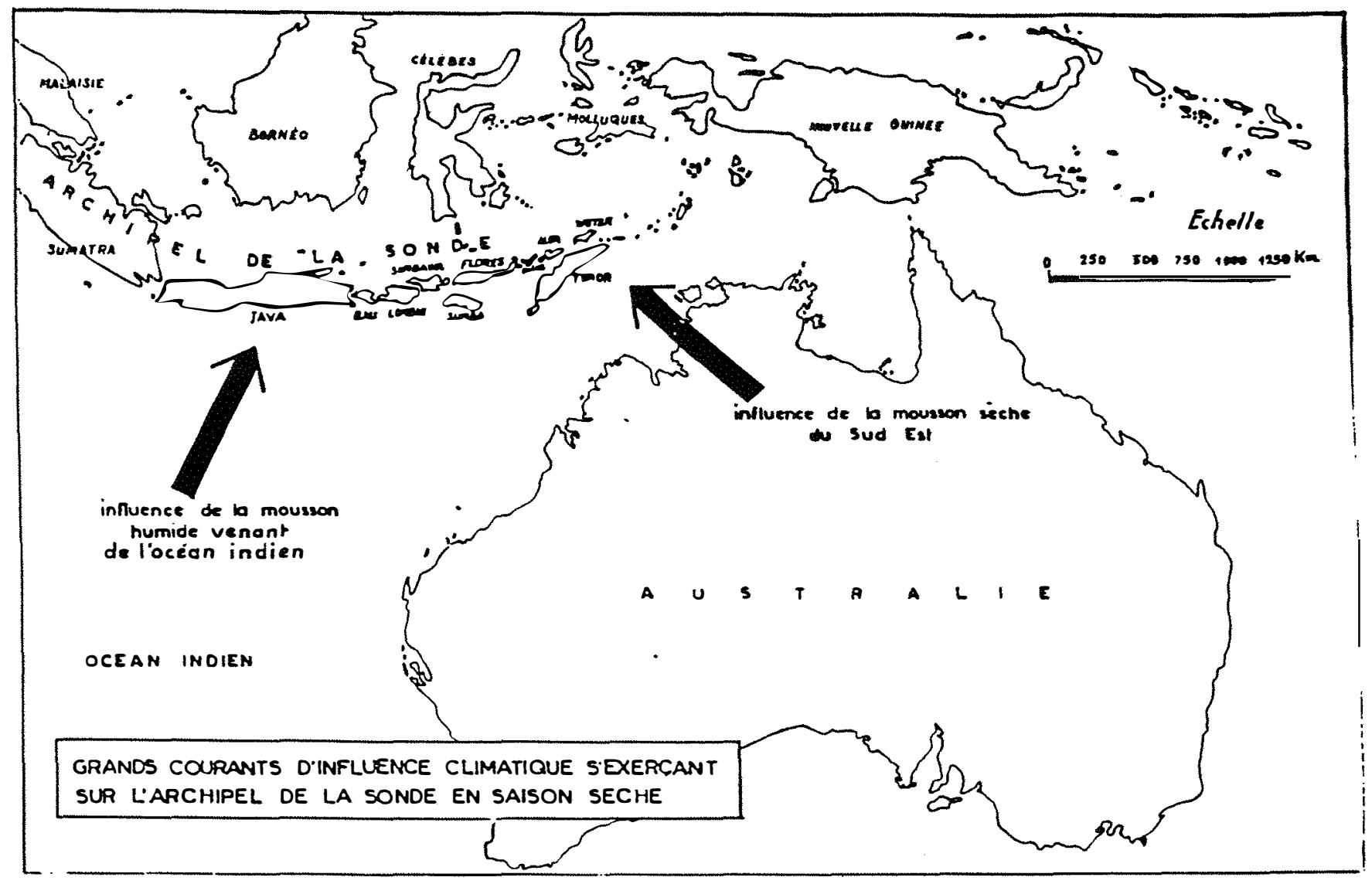

TYPE DE PLUVIOMETRIE dES ILES SUD DE LA SONDE

Dopres le ropport entre le nombre de mais sees et le nombre de mois humides.
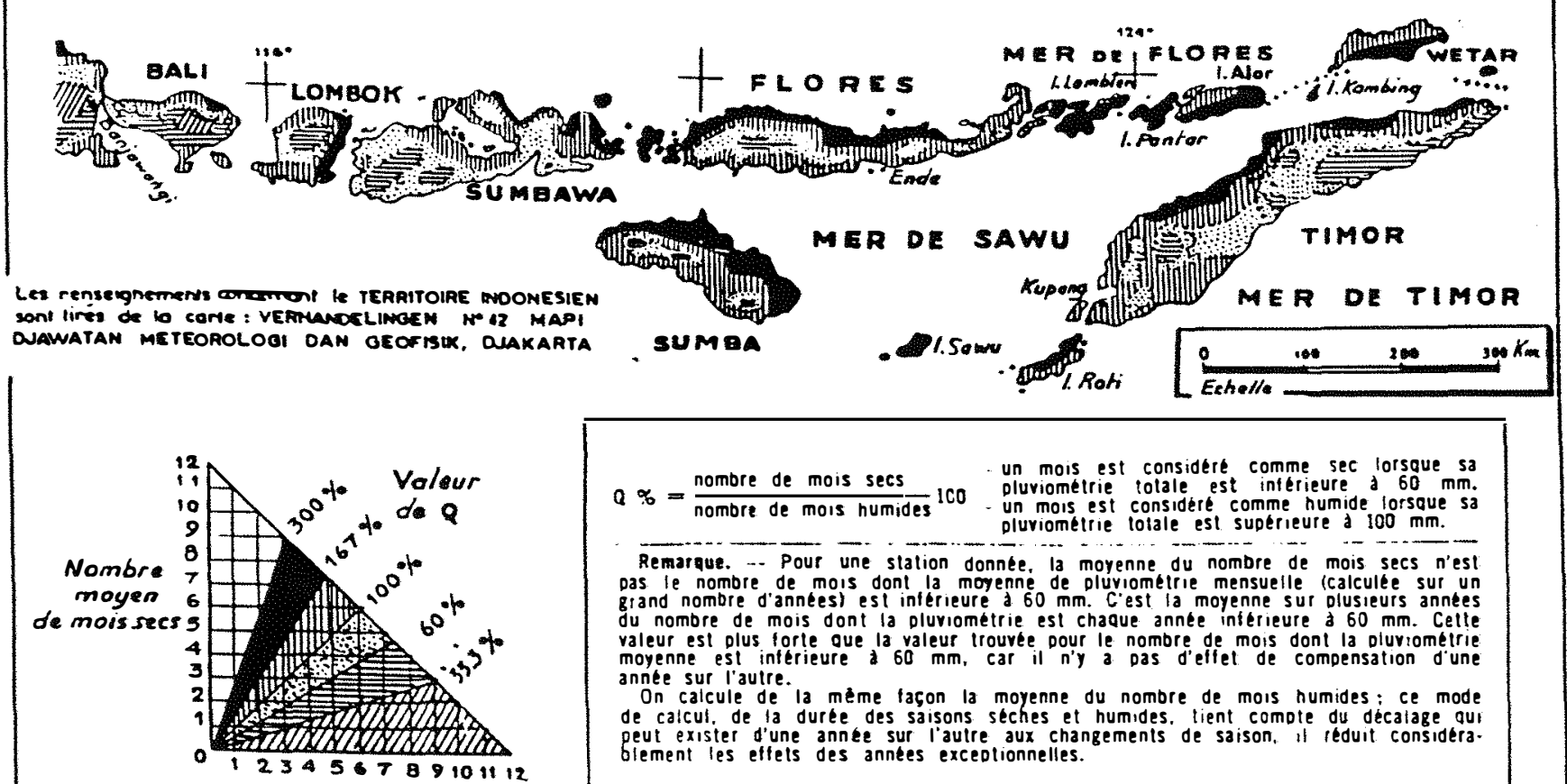

Nombre moyen demois humides

Influência do clima sobre as populações naturais de E. urophylla. 
गTACHE No

E. alba des iles de la somde

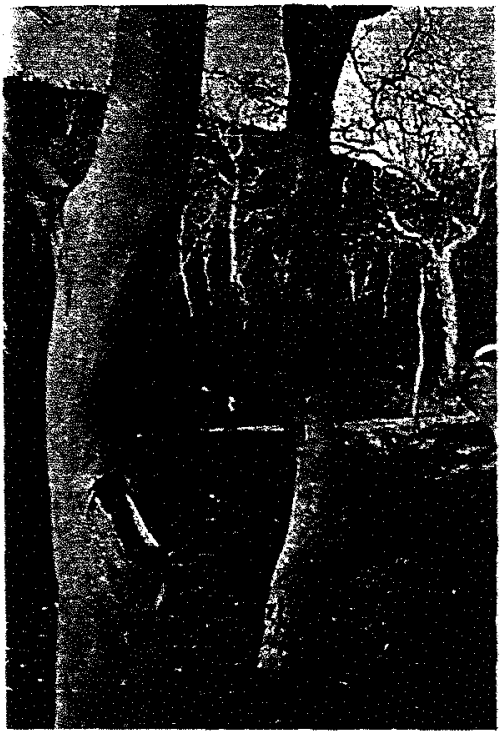

Photo Iratin.

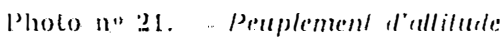
"nlre dilen el .1/culbisst?

(P'artir porlugasse de T'imst.

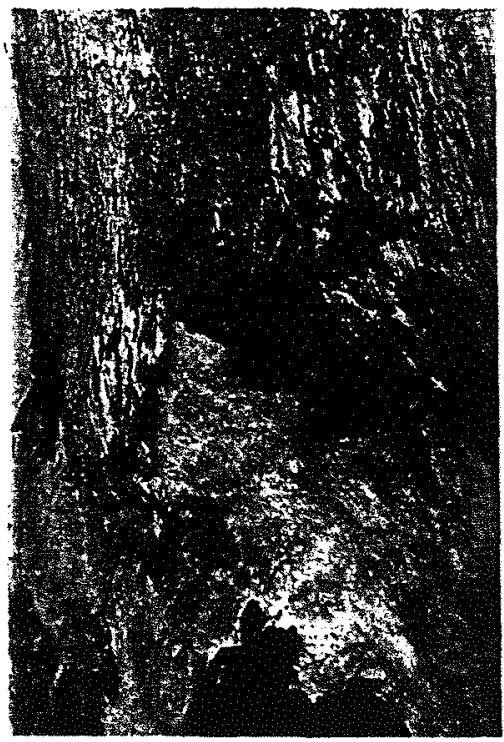

Ph:to cinsalter.

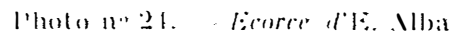
dis munlutmir.

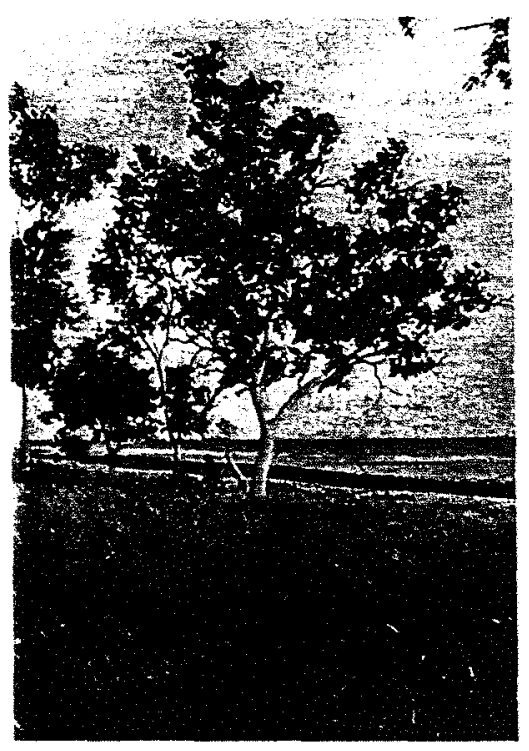

Platolo Consillter.

Photo n" 2.2. - Penplement ali. alba sur la risile . Noril

de let purlie portulguise de Timor.

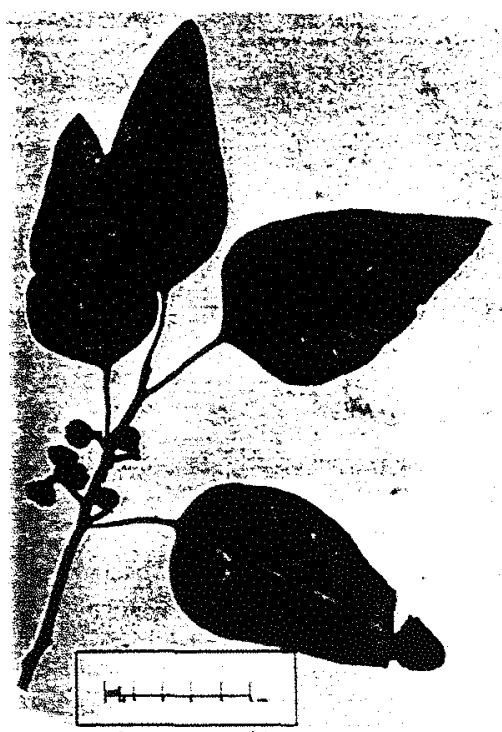

Phulo linsitler.

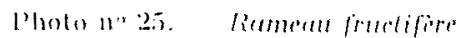

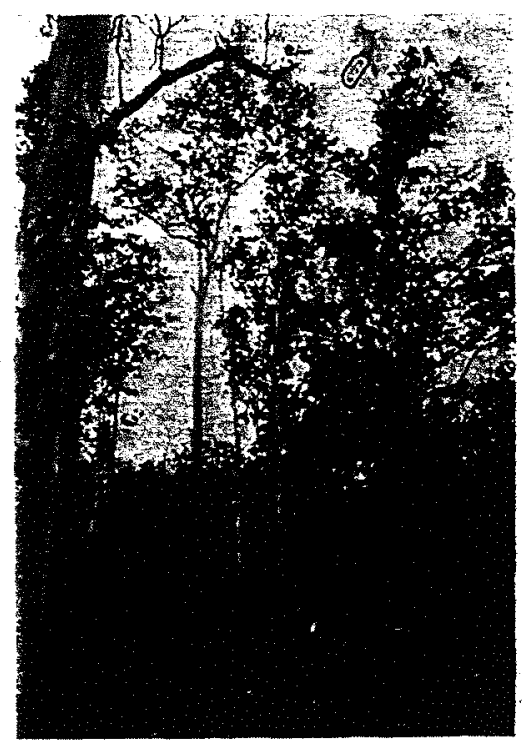

Photo Cossulter.

Photo n" 2.3. - Tress beat specimen de la ciole surl de la portie porlugaise de l'ile: (. Nalar Bora).

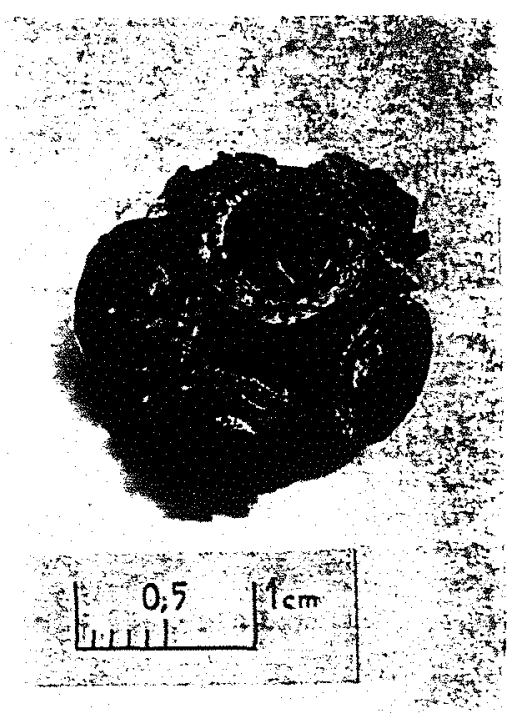

Pholu cossisller

Ploto n" ag. Cilomirule de fruils. 

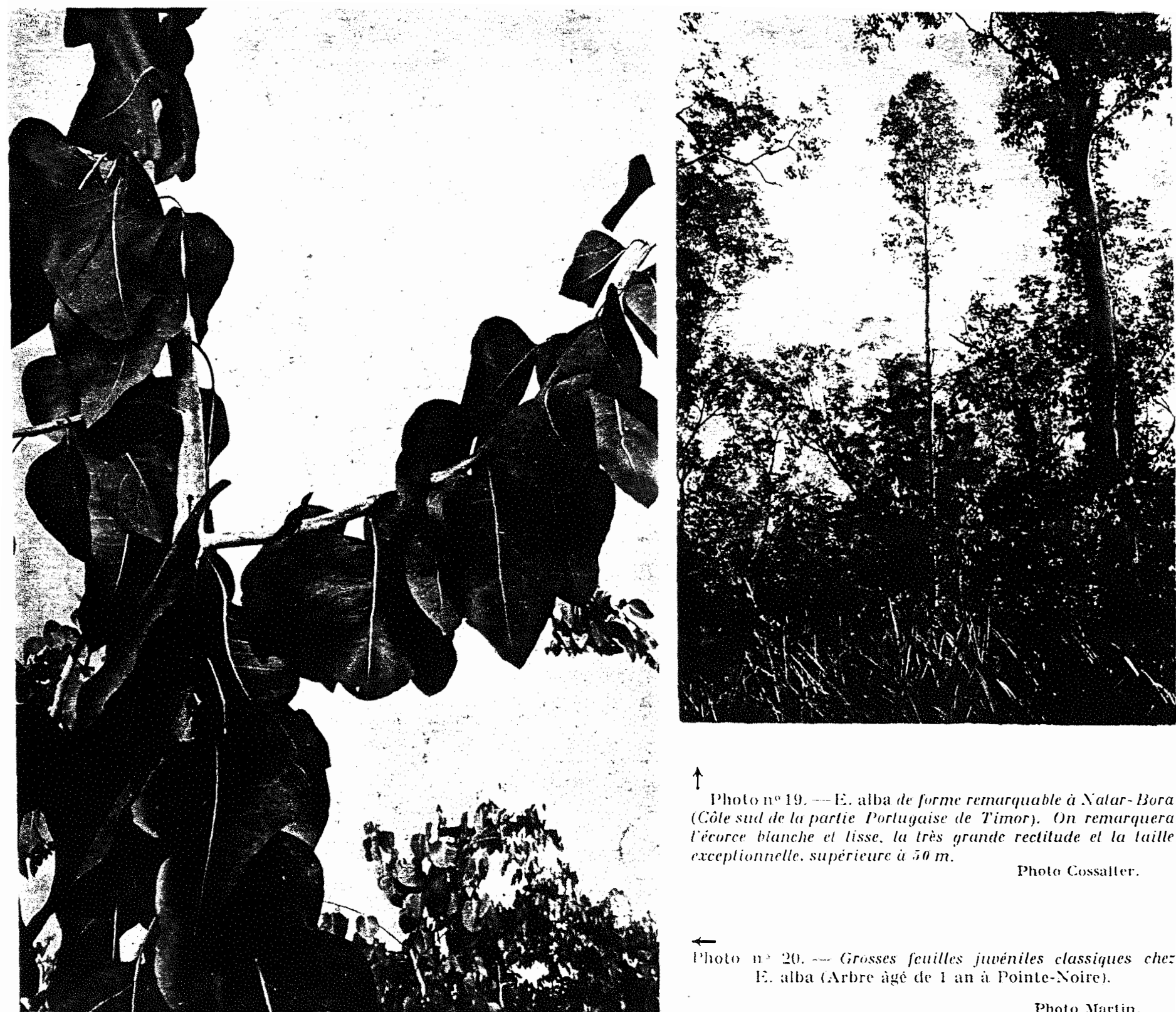

\section{$\uparrow$}

Photo no 19 . E. alba de firme remarquable a Nalar-bura (Cóle sud de la partie l'orlugaise de Timor). On remarquera lieurce blanche el lisse. la très grande rectitude el la laille exceptionnelle. superiéure a in $\mathrm{m}$.

Photo Cossaller.

Thoto $n: 20$.... (irosses fouilles jumeniles classigues che: E. alba (Arbre age de 1 an a Pointe-.ioirel.

Photo Martin.

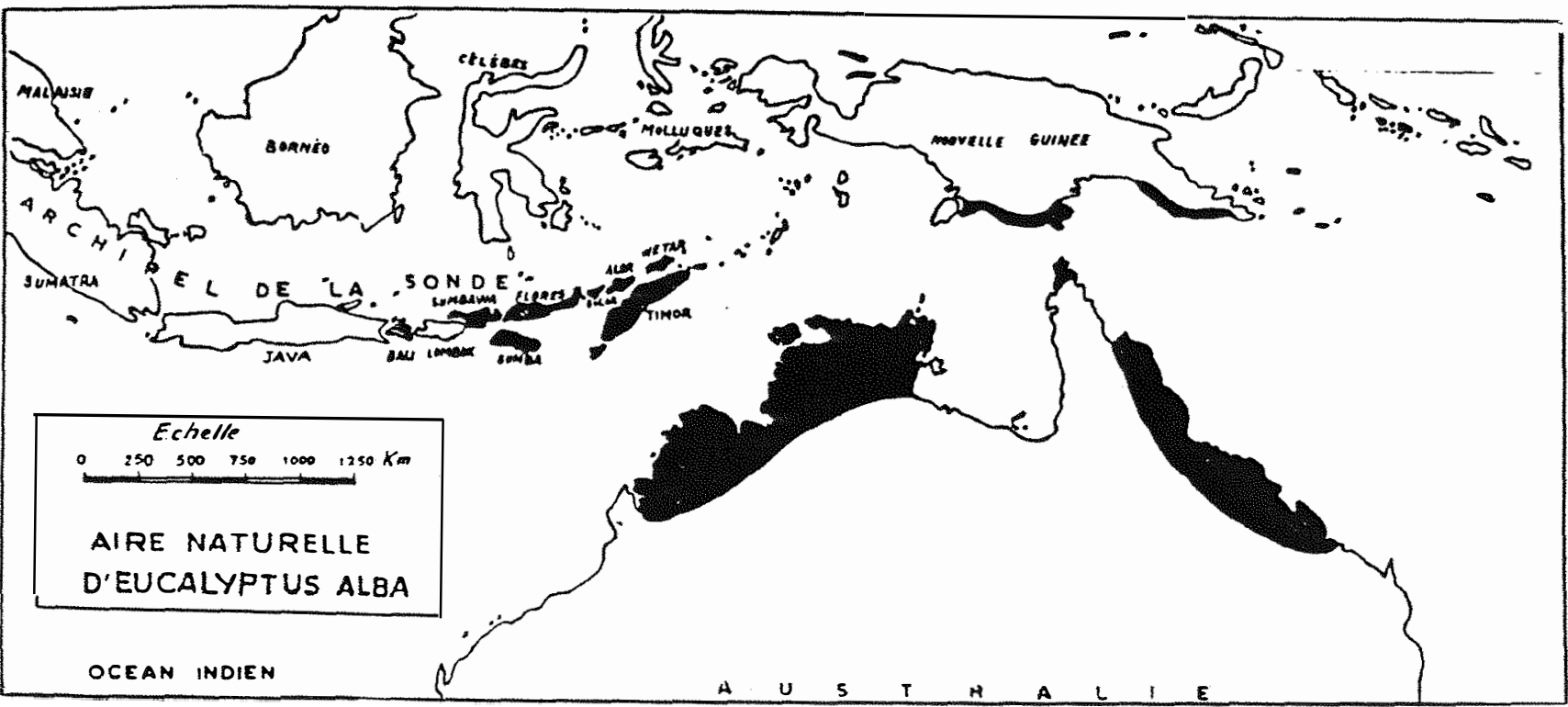



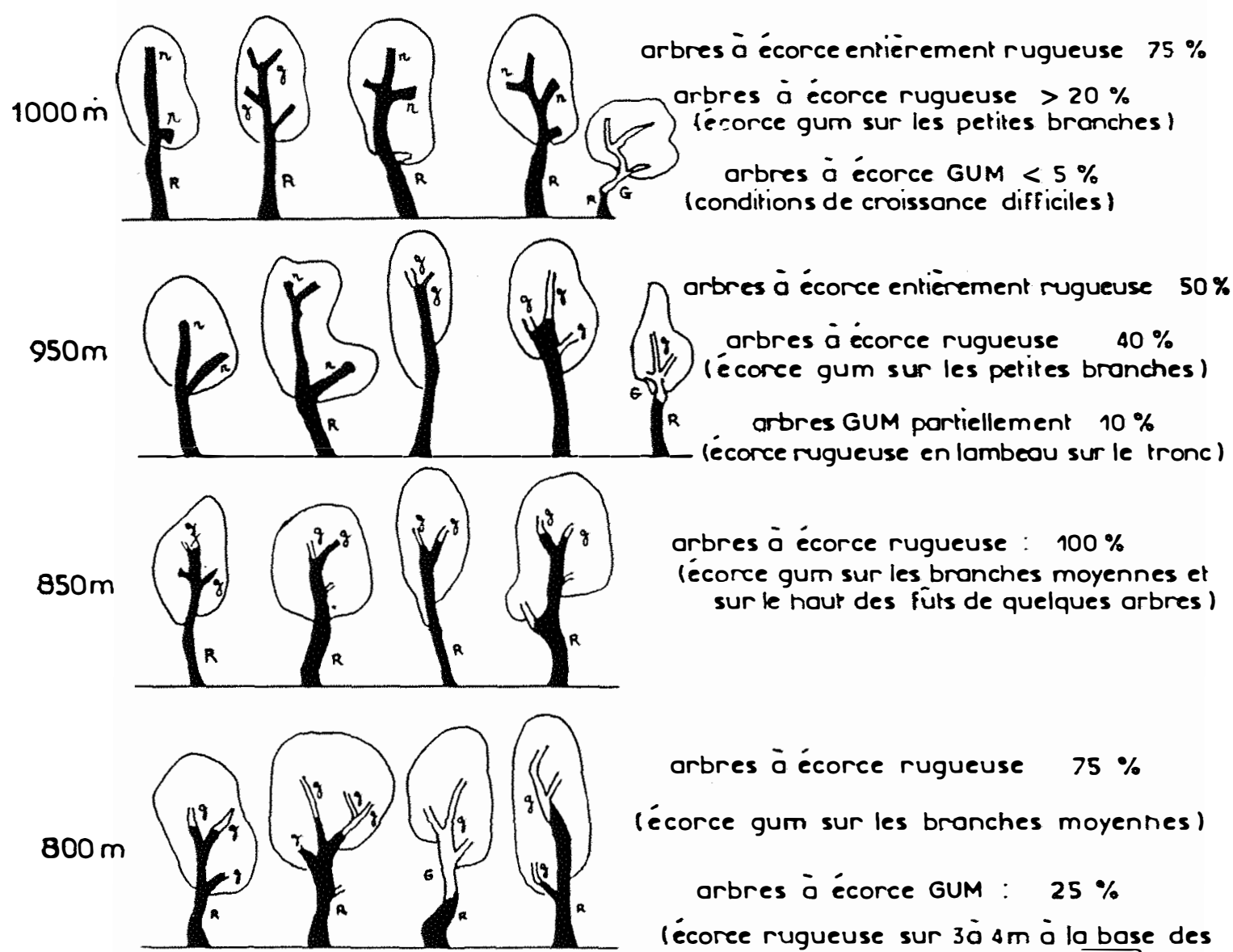

arbres à écorce rugueuse $75 \%$ (écorce gum sur les bronches moyennes) arbres ò écorce GUM : $25 \%$ lécorce rugueuse sur $30 \dot{0} \Delta \mathrm{m}$ ò la base des (rones]

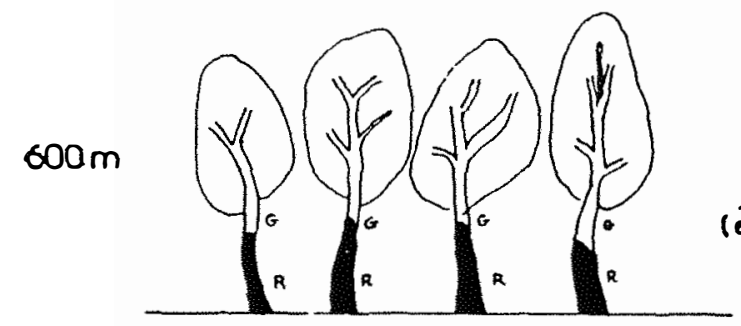

$$
\text { orbres ò écorce GUM : } 100 \%
$$
(écorce rugueuse sur $3 a ̀$ sm à la base des troncs)

$450 \mathrm{~m}$

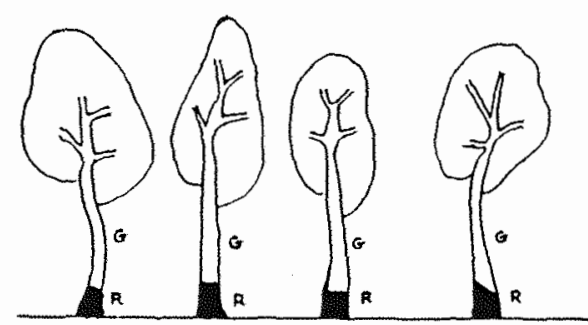

orbres ò écorce GUM : $100 \%$ lécorce rugueuse sur $1 \mathrm{~m}$ à $1,50 \mathrm{~m}$ à la bose des ironcs)

$$
\begin{array}{lll}
G=\text { tronc GUM } & \quad g=\text { branches gum } \\
R=\text { ironc rugueux } & \Omega=\text { branches rug }
\end{array}
$$

Variações naturais do tipo e porcentagem de casca de $E$. urophylla, correlacionadas com a altitude E com o porte e vigor. Ilha Flores. 


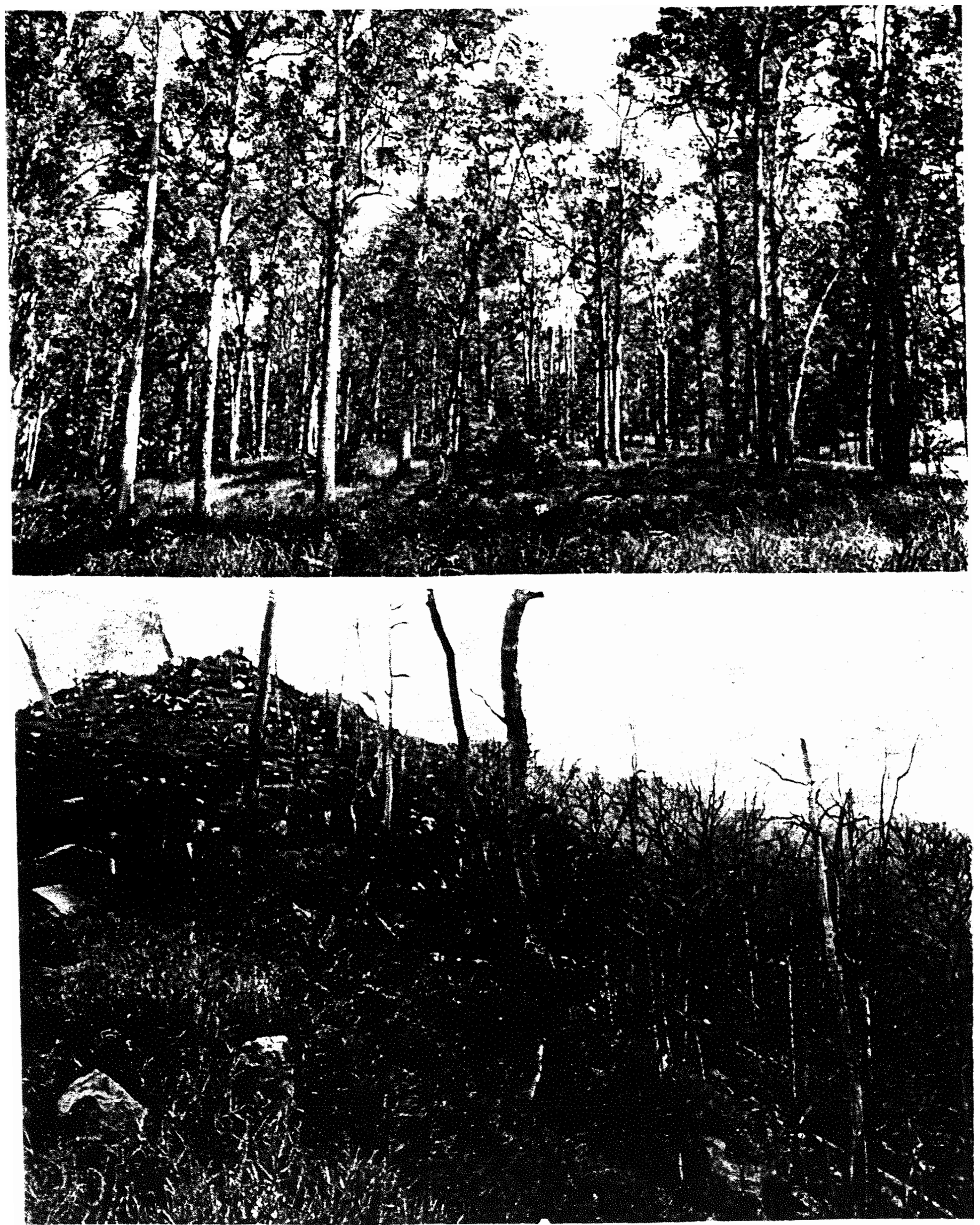

Acima: populacăo de E. urophylla nas encostas do Monte Egon a $700 \mathrm{~m}$ de aititude. Ilha Flores.

4baixo: populaçăo destruida por erupçăo recente do Monte Boleng. a $1.000 \mathrm{~m}$. de altitude. IIha Adonara. 


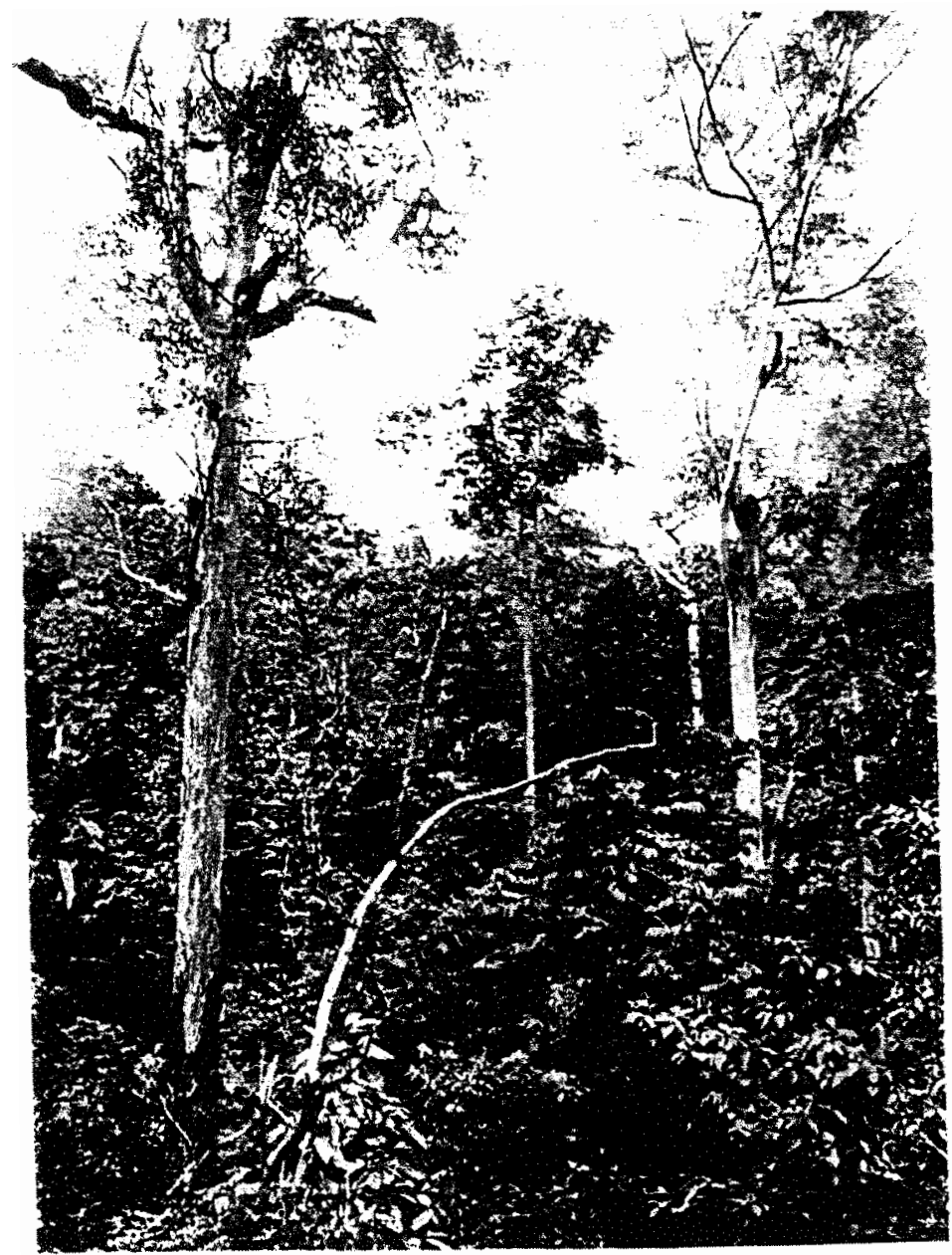

Ao lado: árvores de E. urophylla

casca lisa com altura

superando os $50 \mathrm{~m}$.

emergentes sobre a

floresta tropical densa.

em Lewotobi - 1. Flores.

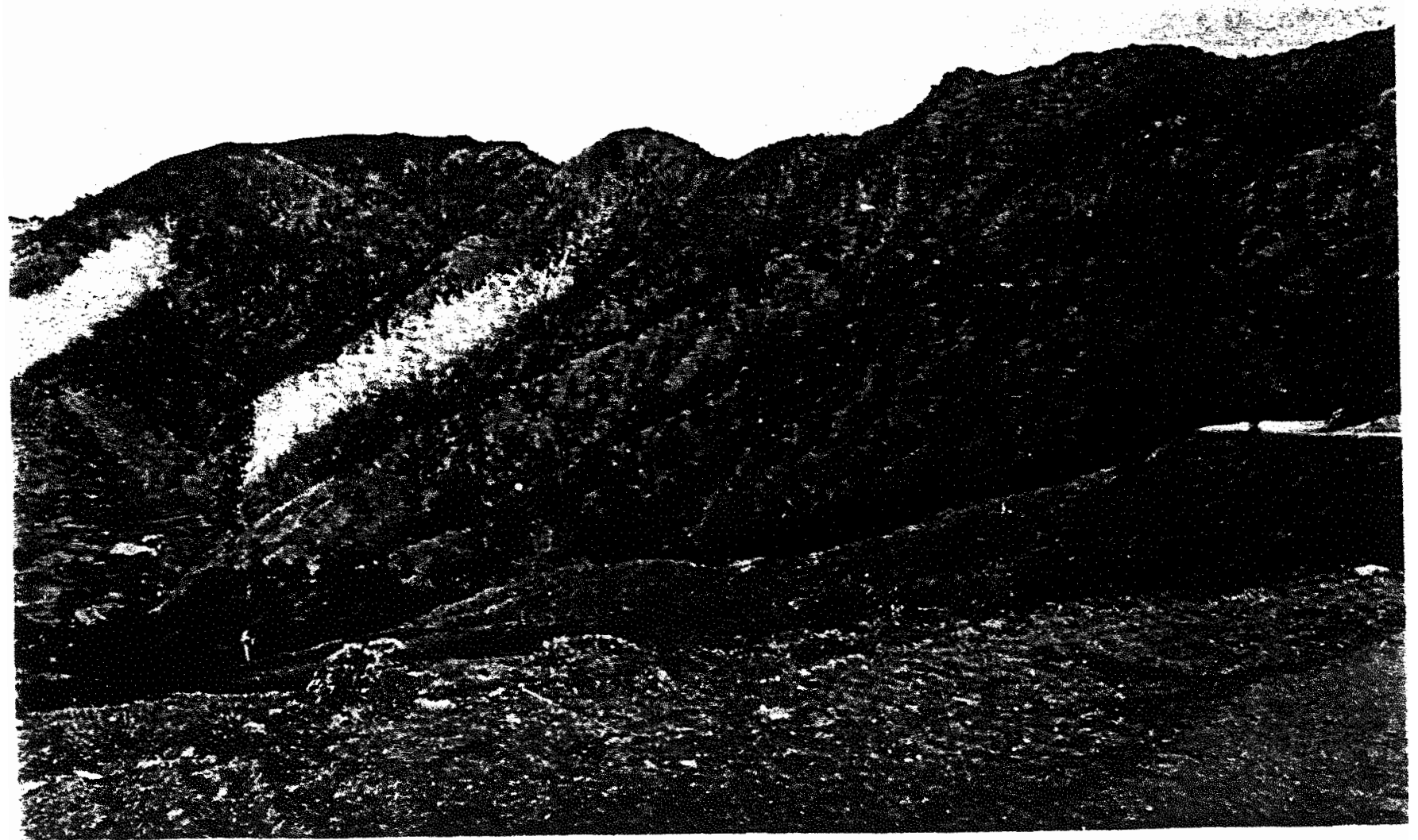




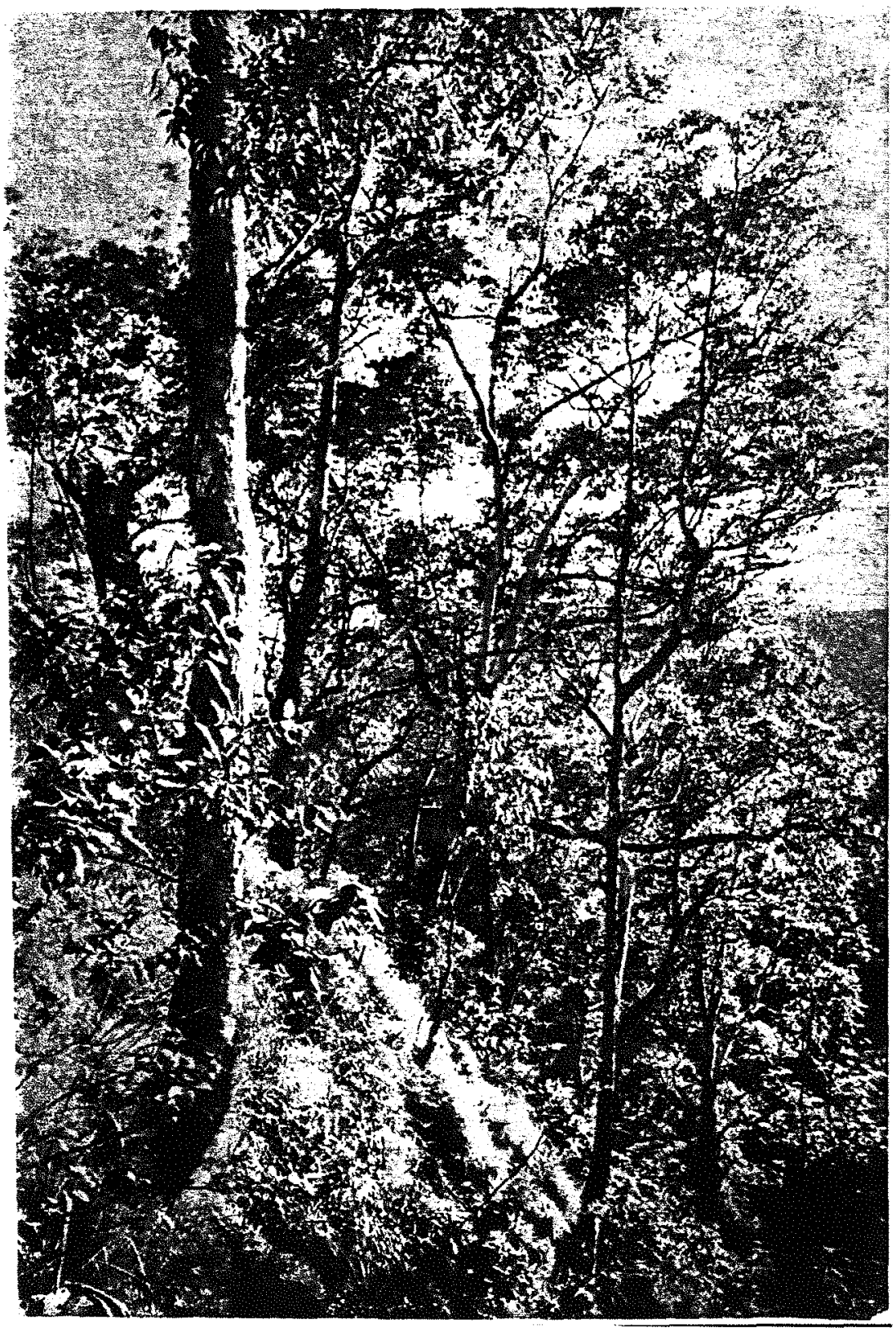

População de E. urophylla em Lomblem, a $500 \mathrm{~m}$ de altitude. sobre solos rasos e secos, em encosta vulcânica pedregosa. 
Photo n" 16. -... F. urophylla it icorce lisse. Région de: Bacan (lle de Lomblent. tllilude x.j") m. On remarnuera la présence décorce rugueusé à la base du lial.

Photo lossalter.

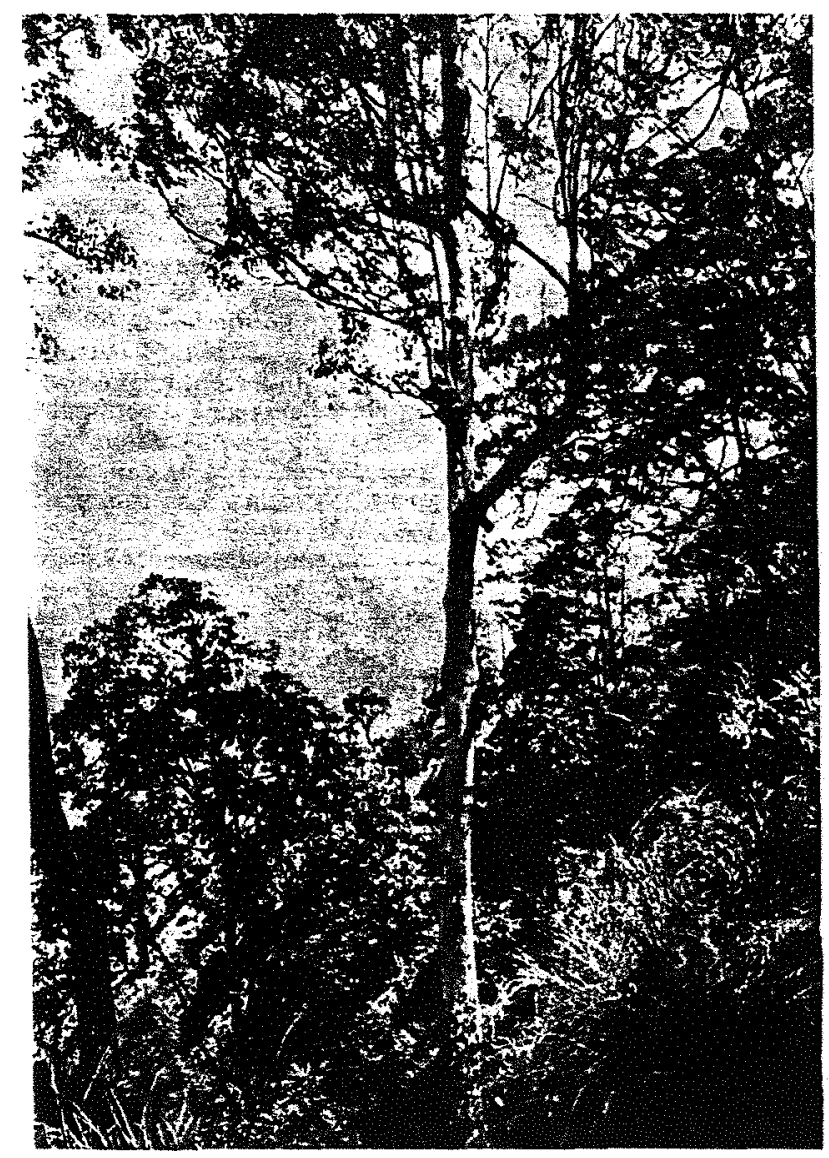

Photo n" 17..... . Ieunc plantalion cigce de: ans is PointeVoire (finngo). Les graines sont ariginaires de lilores

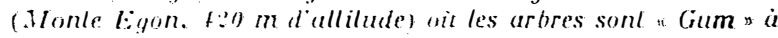
parlir de t..; m ale haul.

Photo Martin.

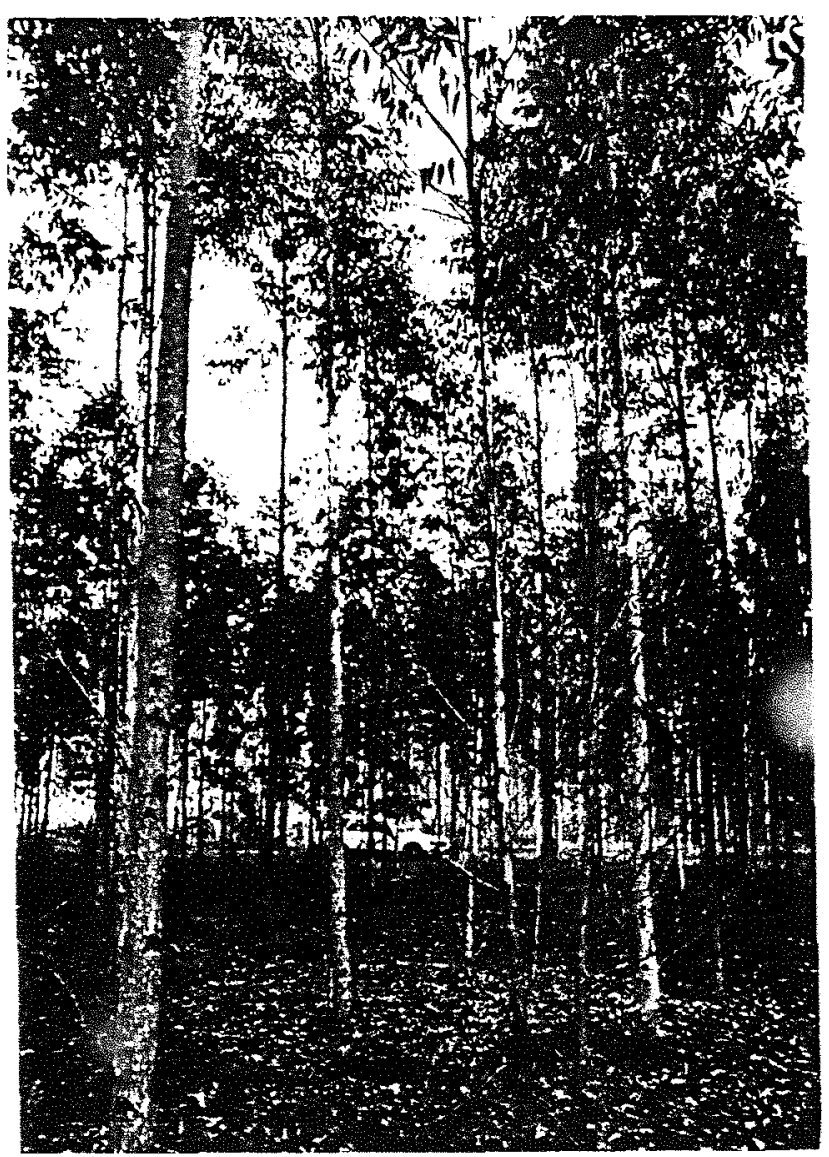

As árvores de $E$. urophylla com casca lisa em Lomblem, a $850 \mathrm{~m}$ de altitude, Assim como em Flores (Egon e Lewotobi), originam progênie com casca lisa em porcentagem variada ao longo do tronco. 


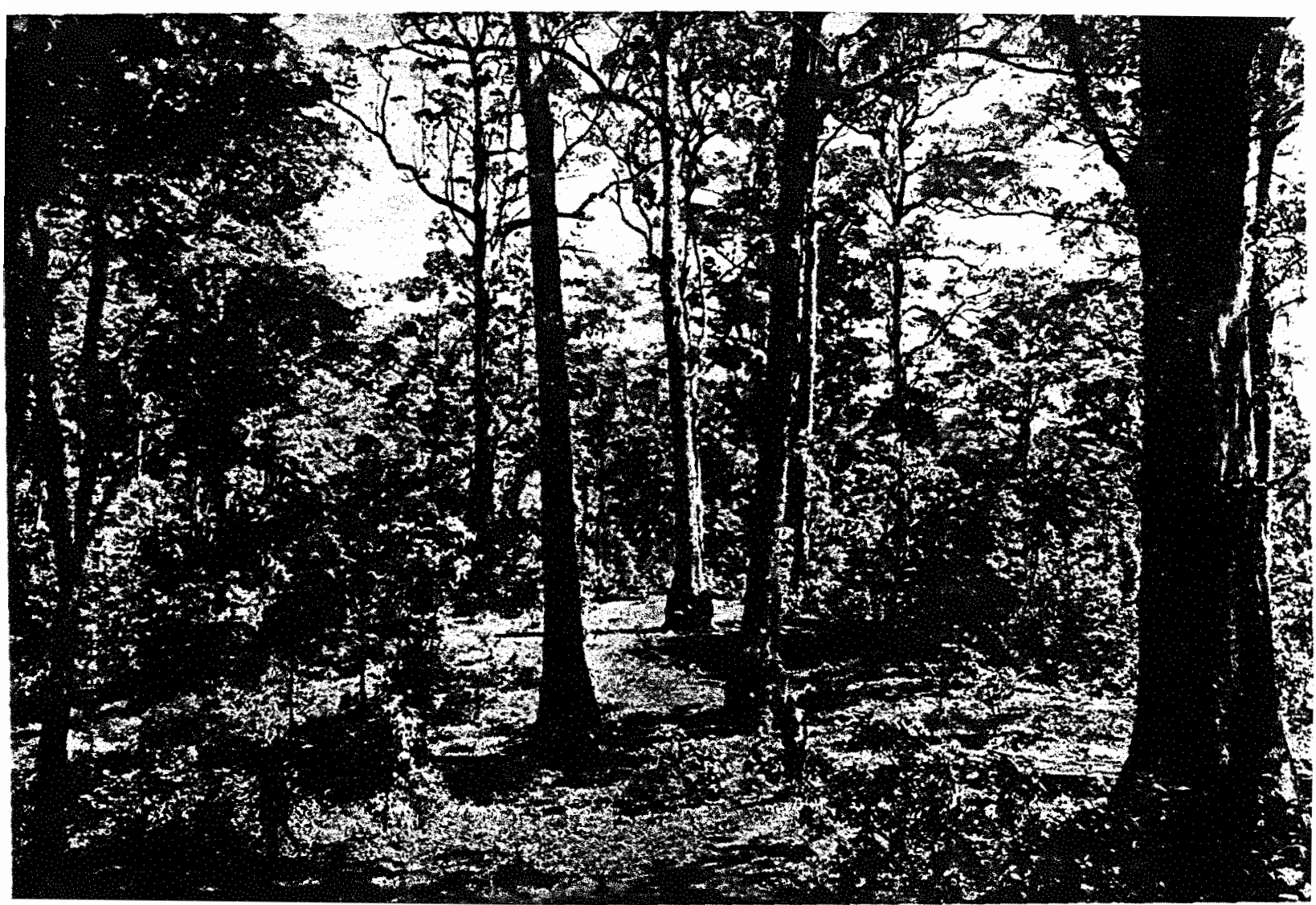

Photo C. Cossalter.

Photo n०.48. - E. urophylla, vieille futaie. Peuplement de Lebo Meta, altitude $9.50 \mathrm{~m}$

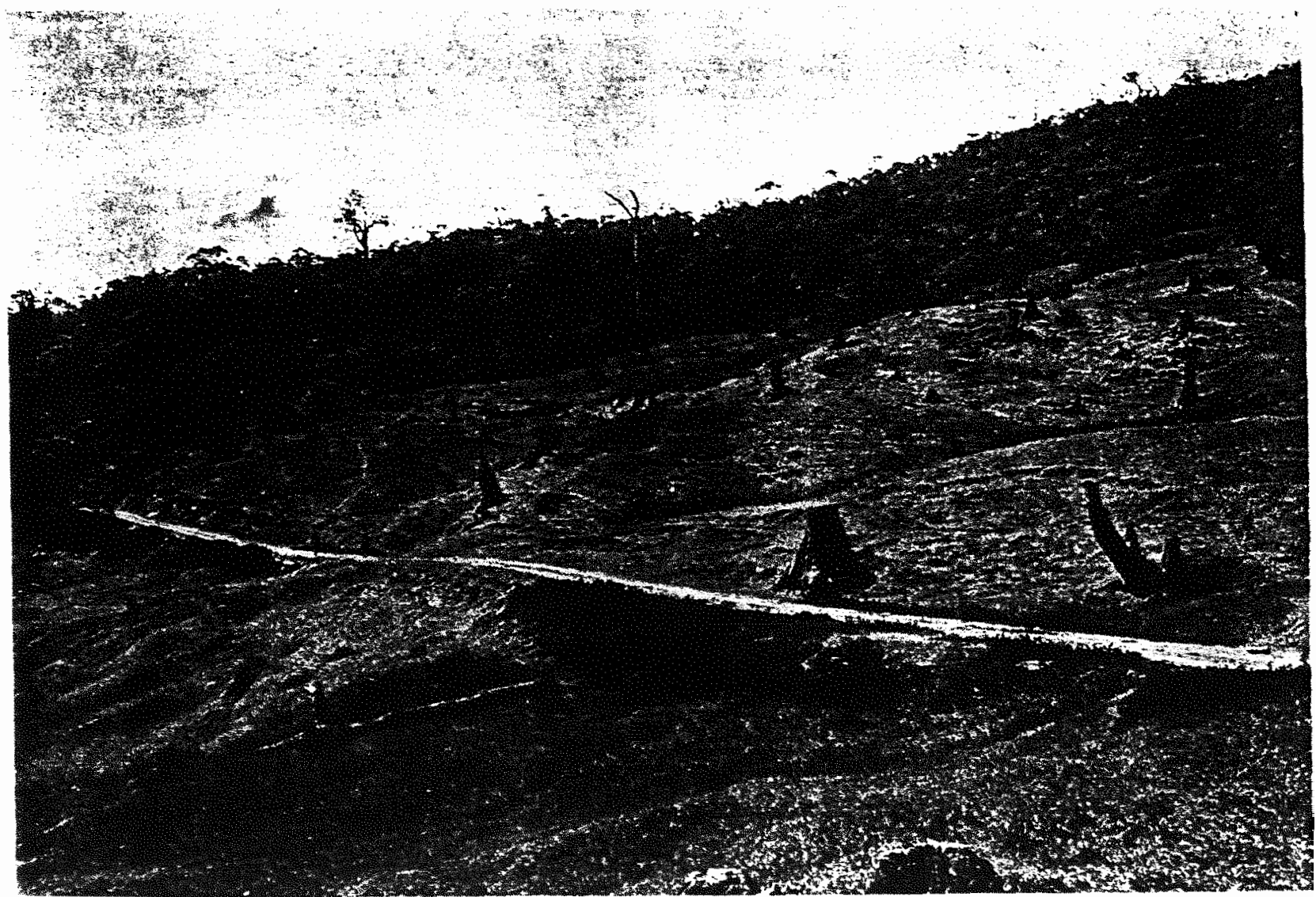

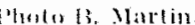




$$
\begin{aligned}
& \frac{1601}{106} \\
& 01100 \text { bisose } \\
& \text { Tivii }(001) \frac{0101}{0100} \\
& \text { opra } 10101
\end{aligned}
$$

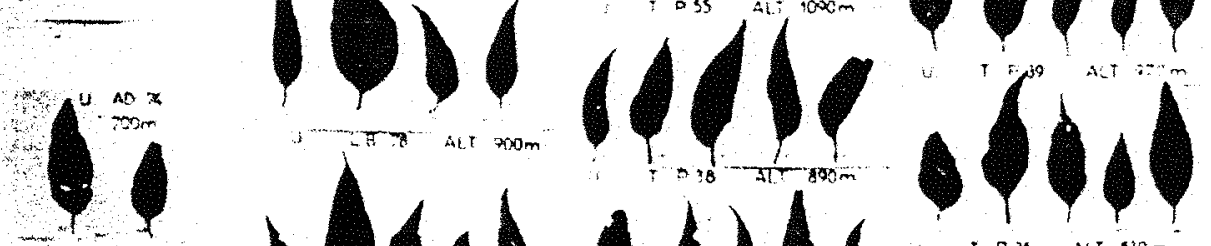

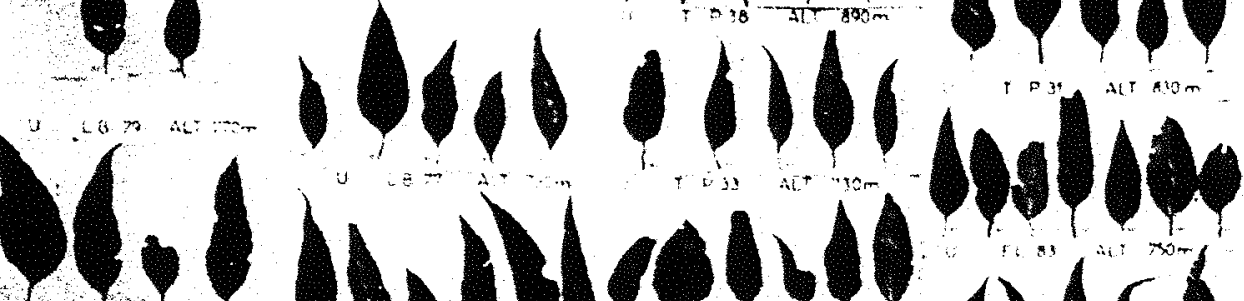

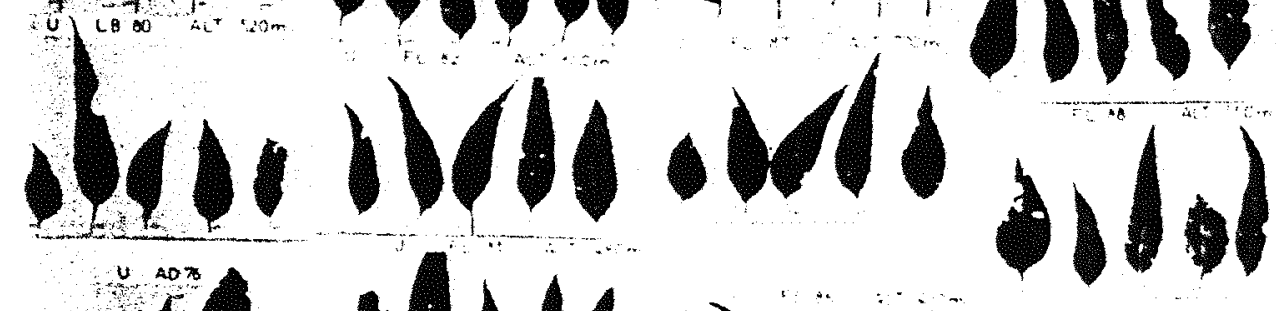

$$
\begin{aligned}
& \text { ic } 0016 \text { niad }
\end{aligned}
$$



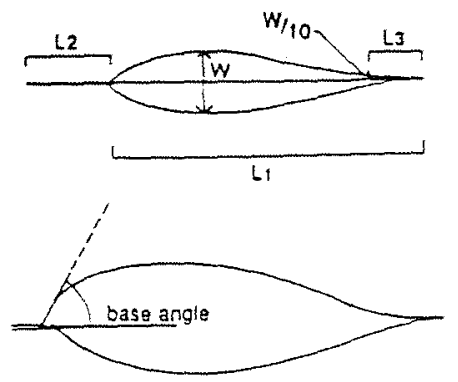

$L_{1}$ - iength of lamina imm)

L2 = iength of peliole $(\mathrm{mm}$

W - width of widest vart of lamina itmm)

L3 = iength ol drio tio imeasured l:am

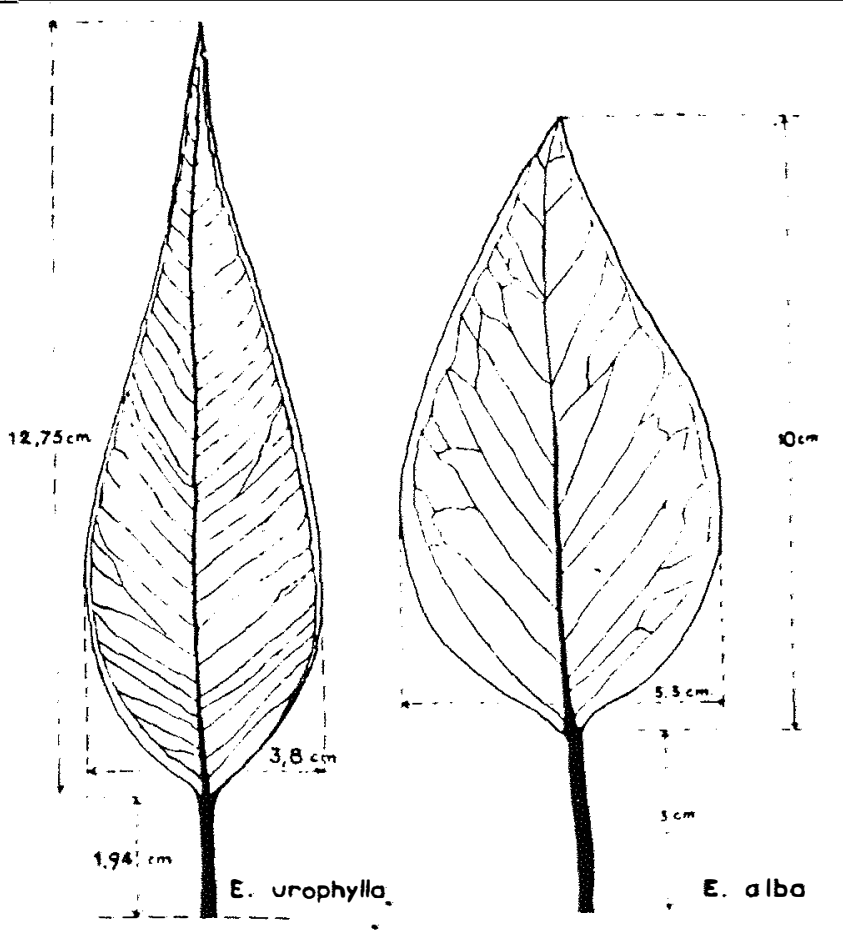

Schémo type des fevilles adultes devcolyptus urophylla et albo des iles de la Sonde

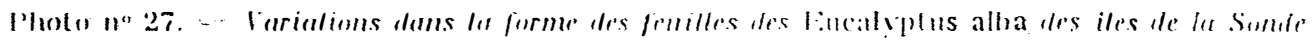

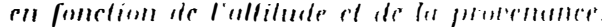

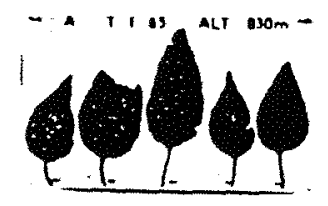

Varialions clans la forme des fevilles

cly R EUCALYPTUS ALBA

des Iles de la Sonde.
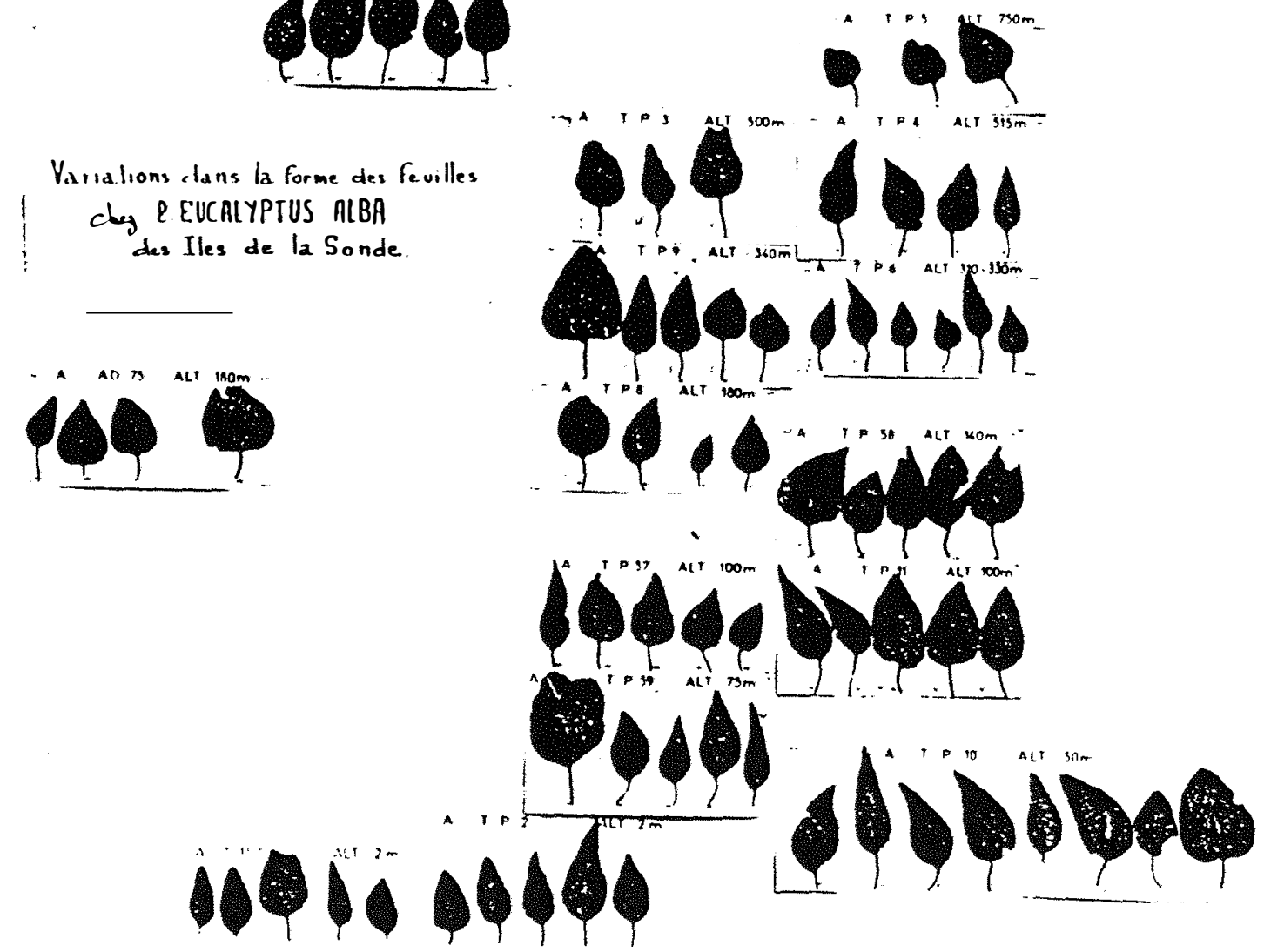

Variabilidade de tipos de folha estudada para E. alba. assim como em E. urophylla . 
FRUIT

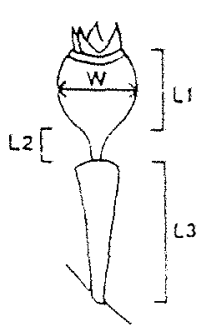

L1 - length of capsula $(\mathrm{mm}$

L2 - length of pedices $(\mathrm{mm})$

$w=$ width of widest Dart of capsule (mm)

$\mathrm{L3}_{3}$ - length ot peduncie

Disc

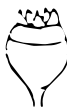

1. Domed

2. Flat

Q

intwards
Fruit Shape
1. Barrei-snaoed

2. Cylindrical

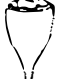

3. Conicai

$\stackrel{5}{2}$

$\therefore$ Campanuiate

Operculum<smiles>C1CCCC1</smiles>

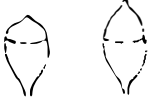

2. Umoonate

3. Elonçatzo

Fig. 1. lllustration of measurement points and qualitaque characters assessed tor leaves. juds ano inuls.

DIFFERENTS TYPES DE CAPSLLES DEE CROPHVLLA

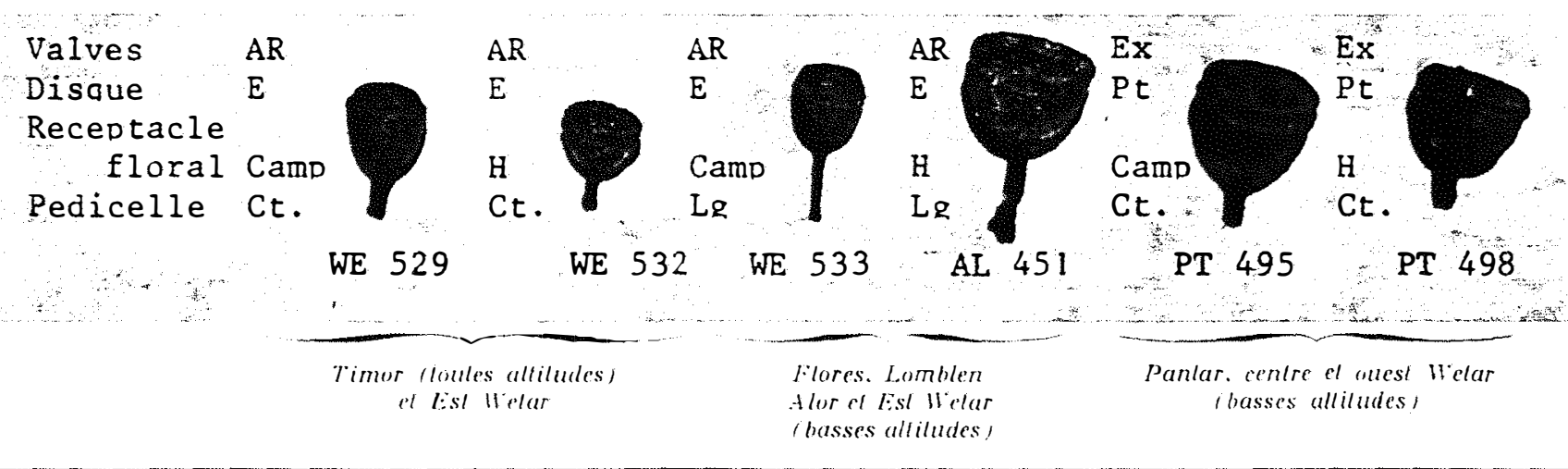

FRLTTS INE TIPES LETREMES

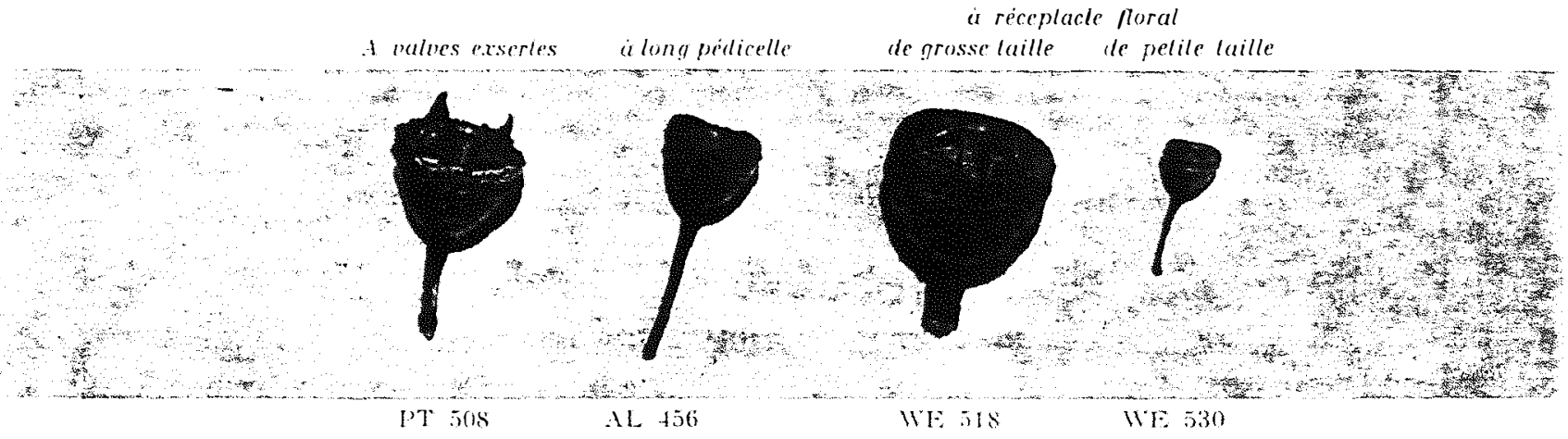

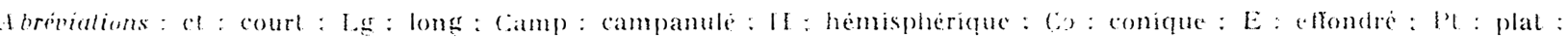
Ar : arasant : Ex: exserte

Grande variabilidade nos tipos de fruto para $E$. urophylla. abrangendo todas as procedências. 

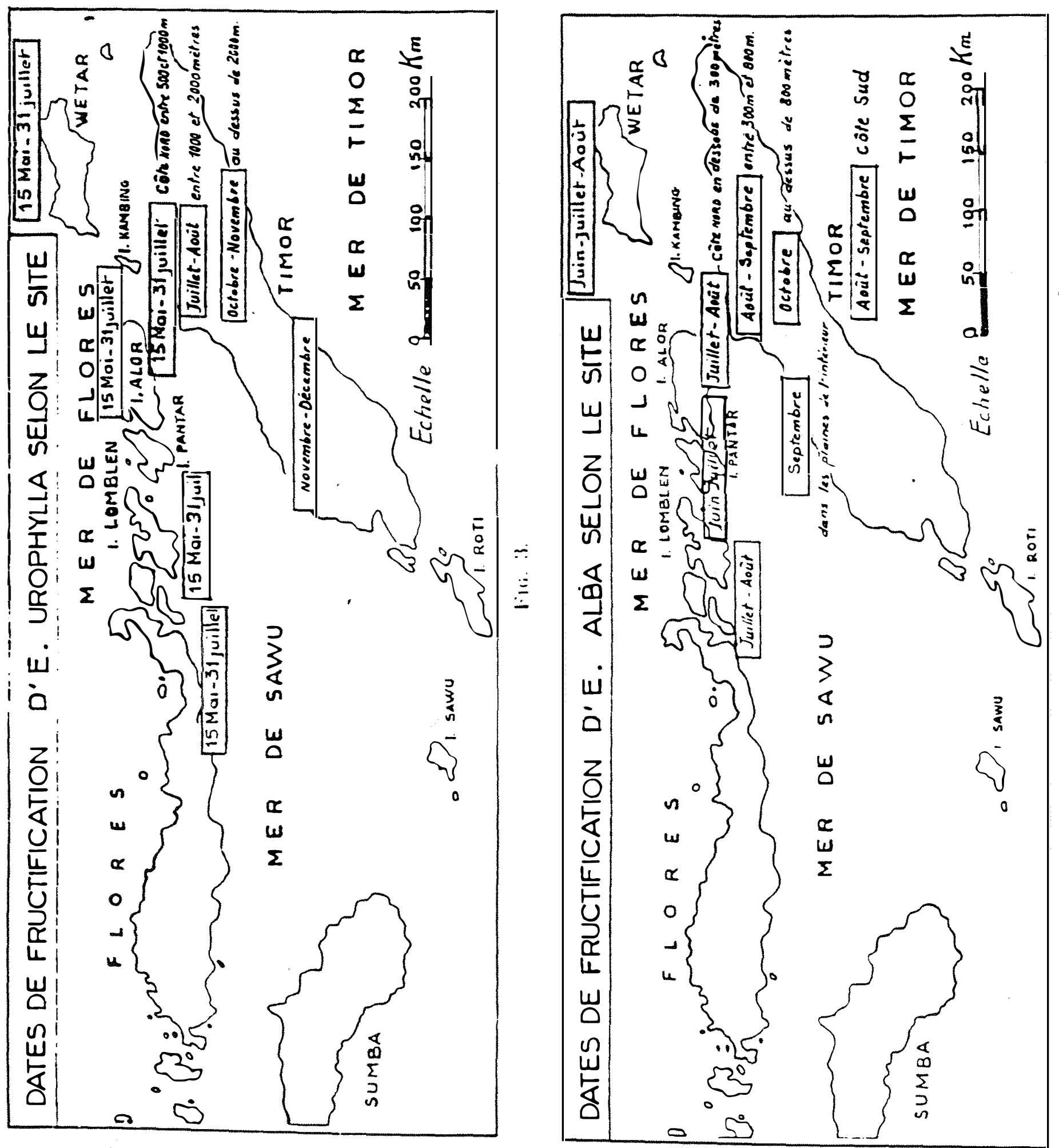

Épocas de frutificação que podem indicar possibilidade de cruzamento e hibridação entre E. urophylla e E. alba na região de origem. 


\section{APÊNDICE 2}

Fotografia dos experimentos estudados

e

exemplos de fotografias de frutos das

árvores superiores de E. urophylla nos dois experimentos,

em Anhembi e Bofete - SP e

na população original 

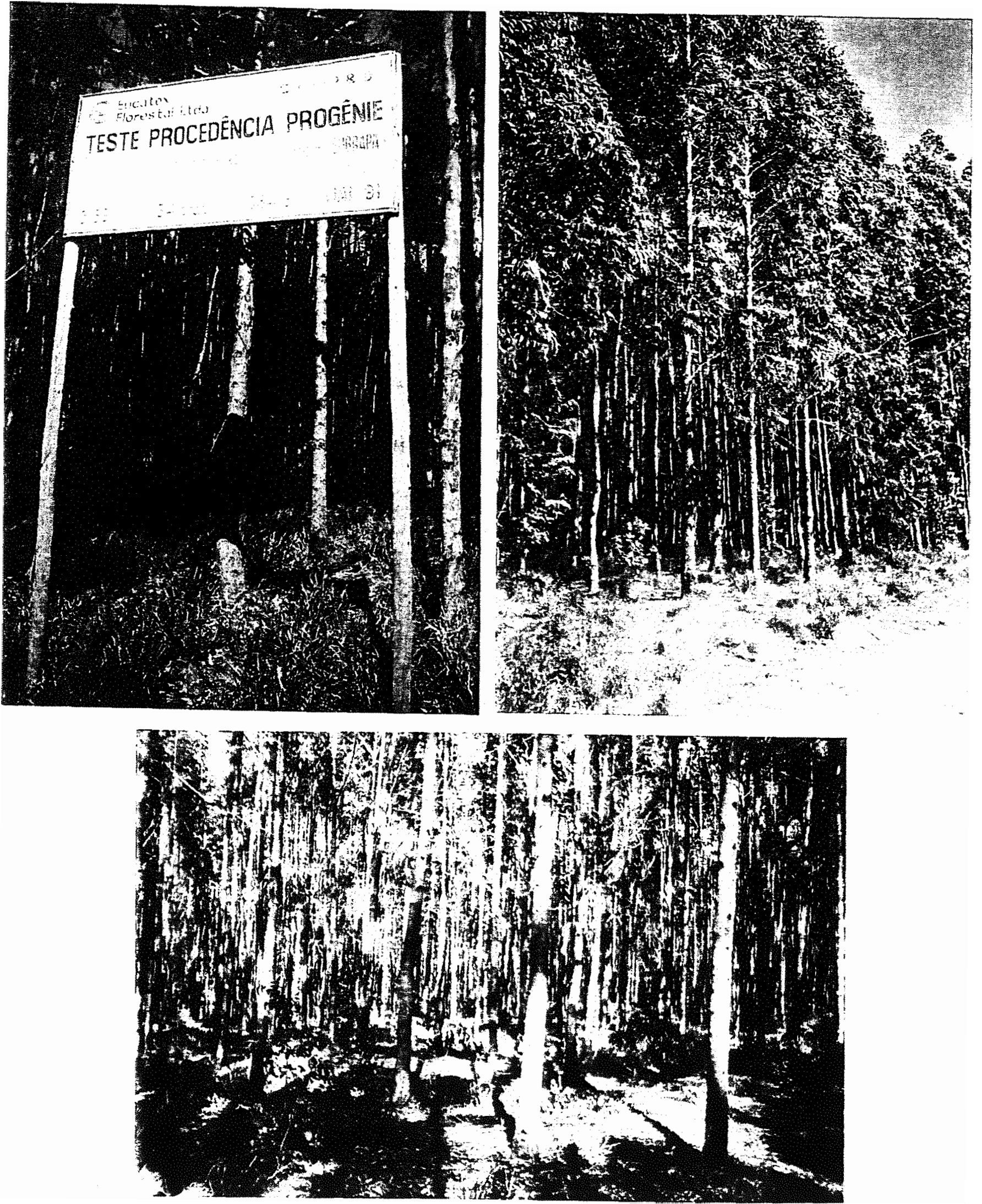

Vista geral do experımento 1 em Bofete. aos 5 anos 

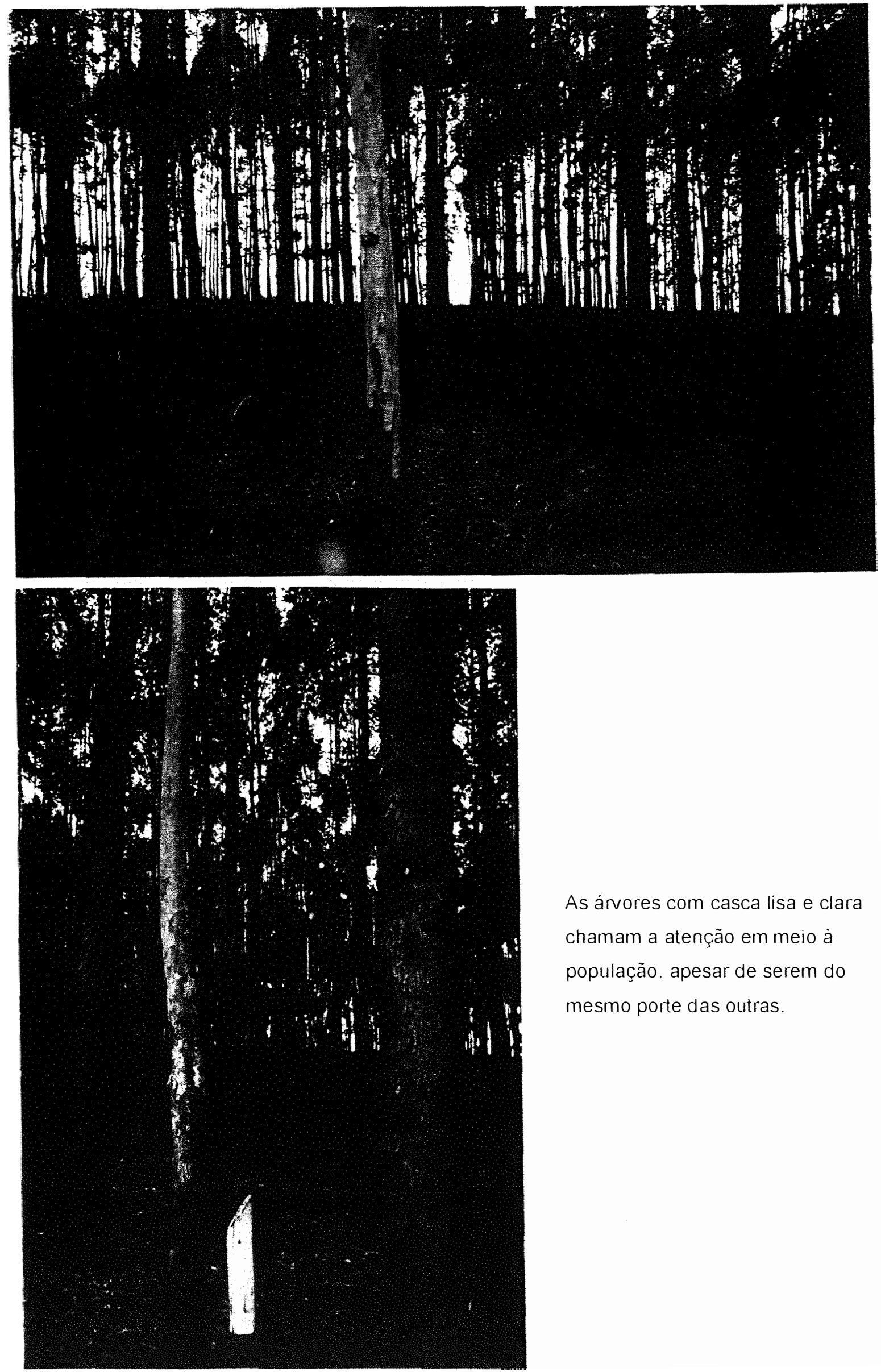

As ánores com casca lisa e clara chamam a atenção em meio à população, apesar de serem do mesmo porte das outras. 


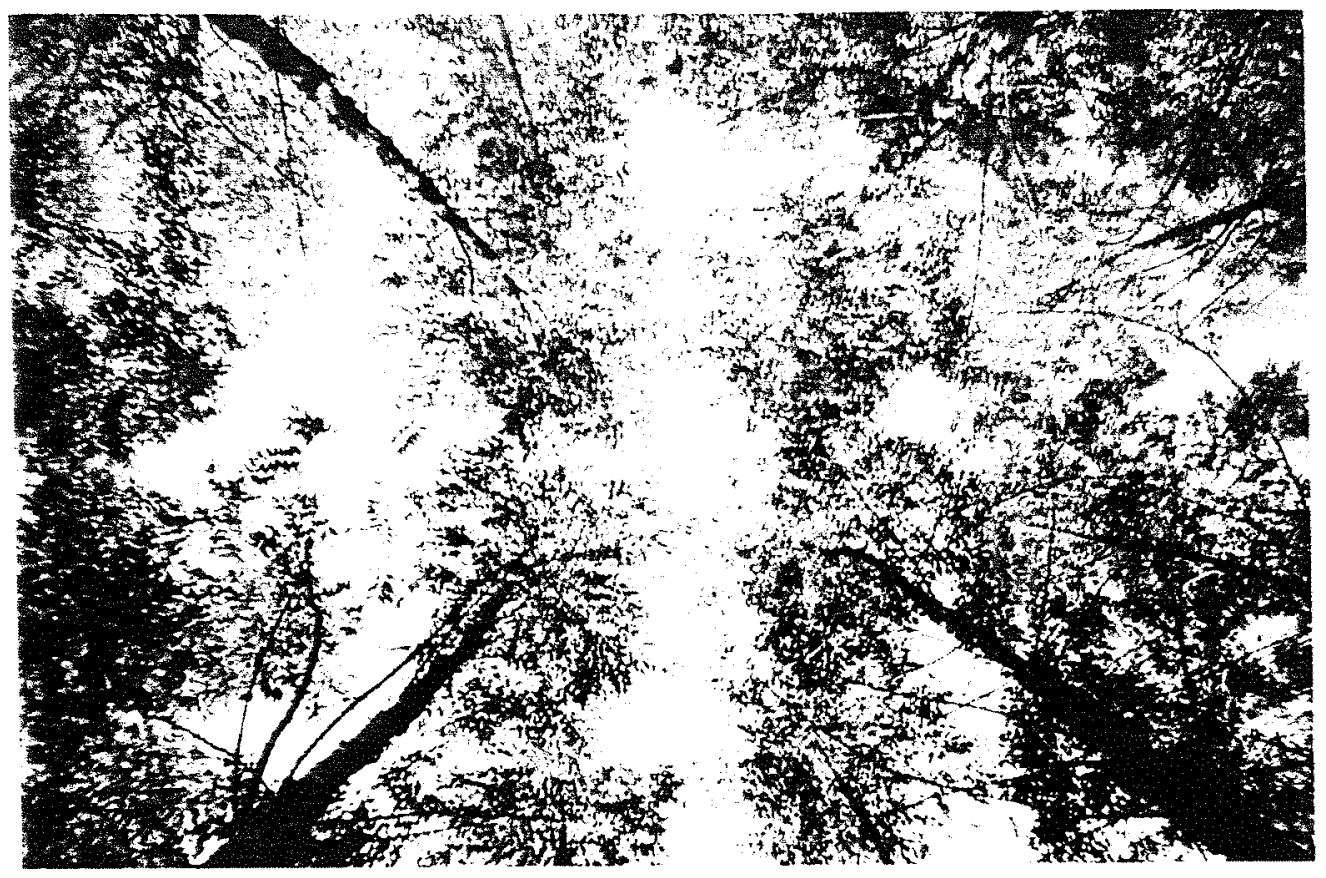

Copas de árvores superiores aglomeradas,

predominando casca lisa ou rugosa em todas.

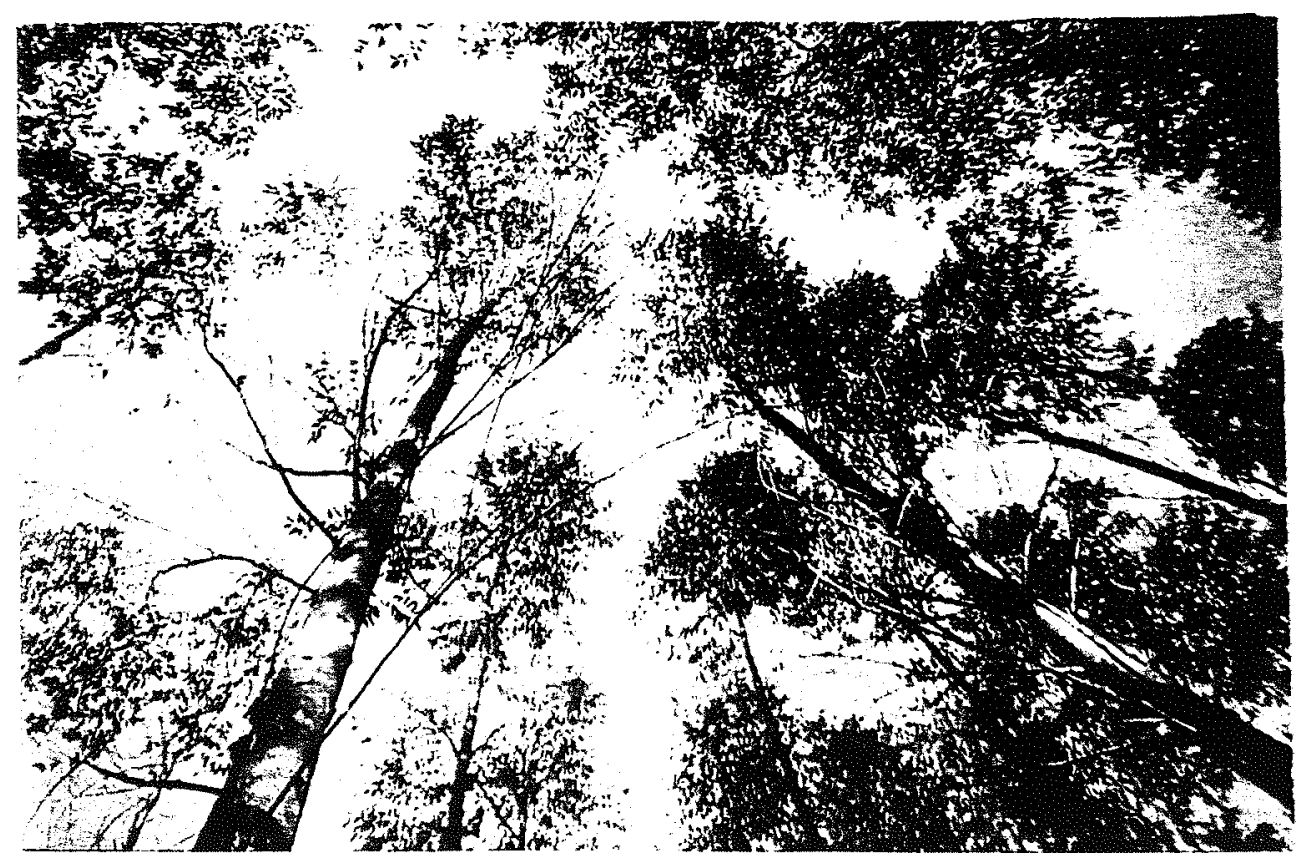

À esq. àrvore com casca lisa e copa mais clara,

A dir. árvore com casca fibrosa e copa compacta. 

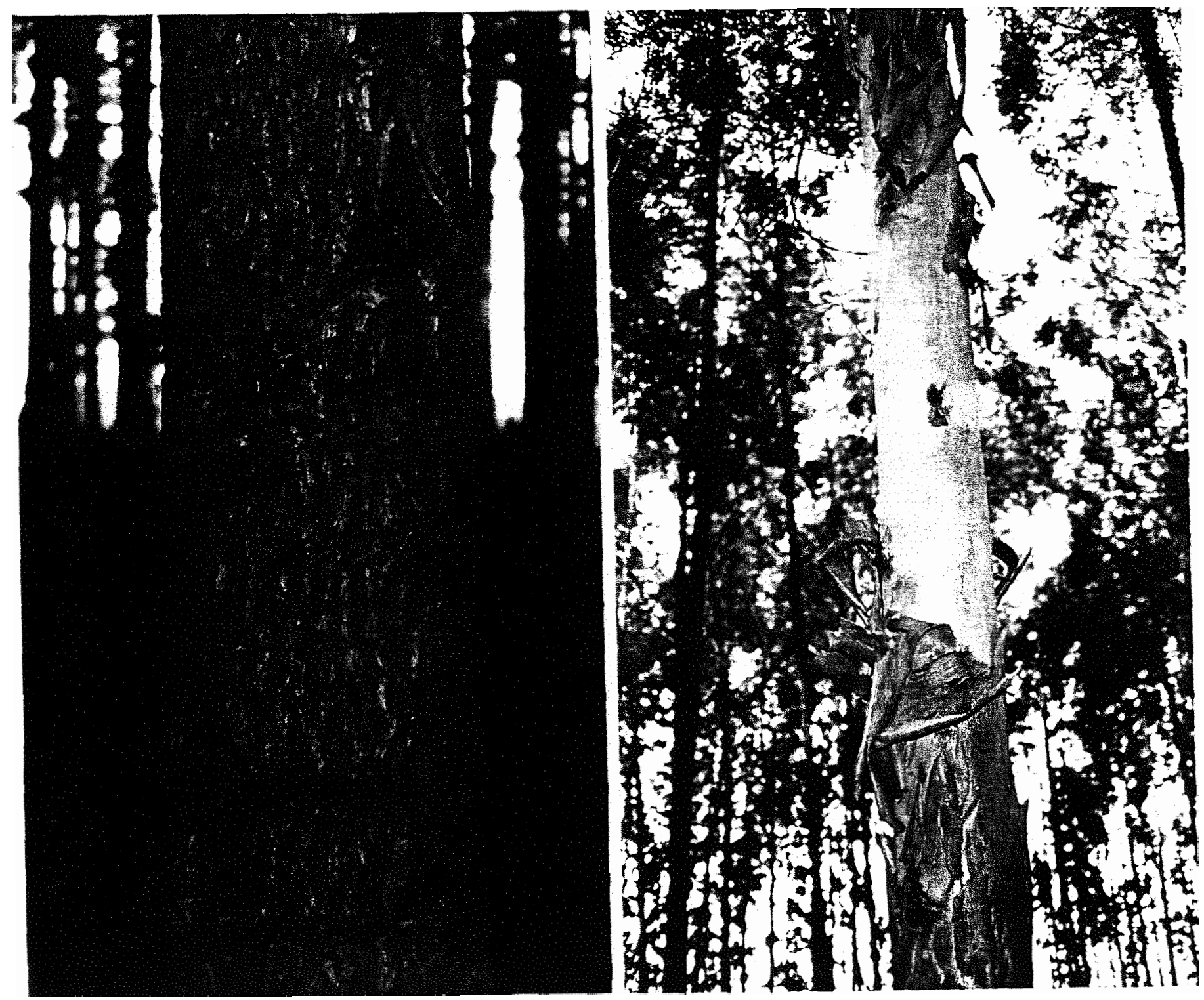

Ideotipos básicos definidos neste estudo. A principio, em idades mais jovens, entre 2 a 4 anos, somente dois foram definidos. Com o passar dos anos, até os 5 a 6 . surgiram outros tipos que passaram a ser considerados, cujas varições estão a seguir 

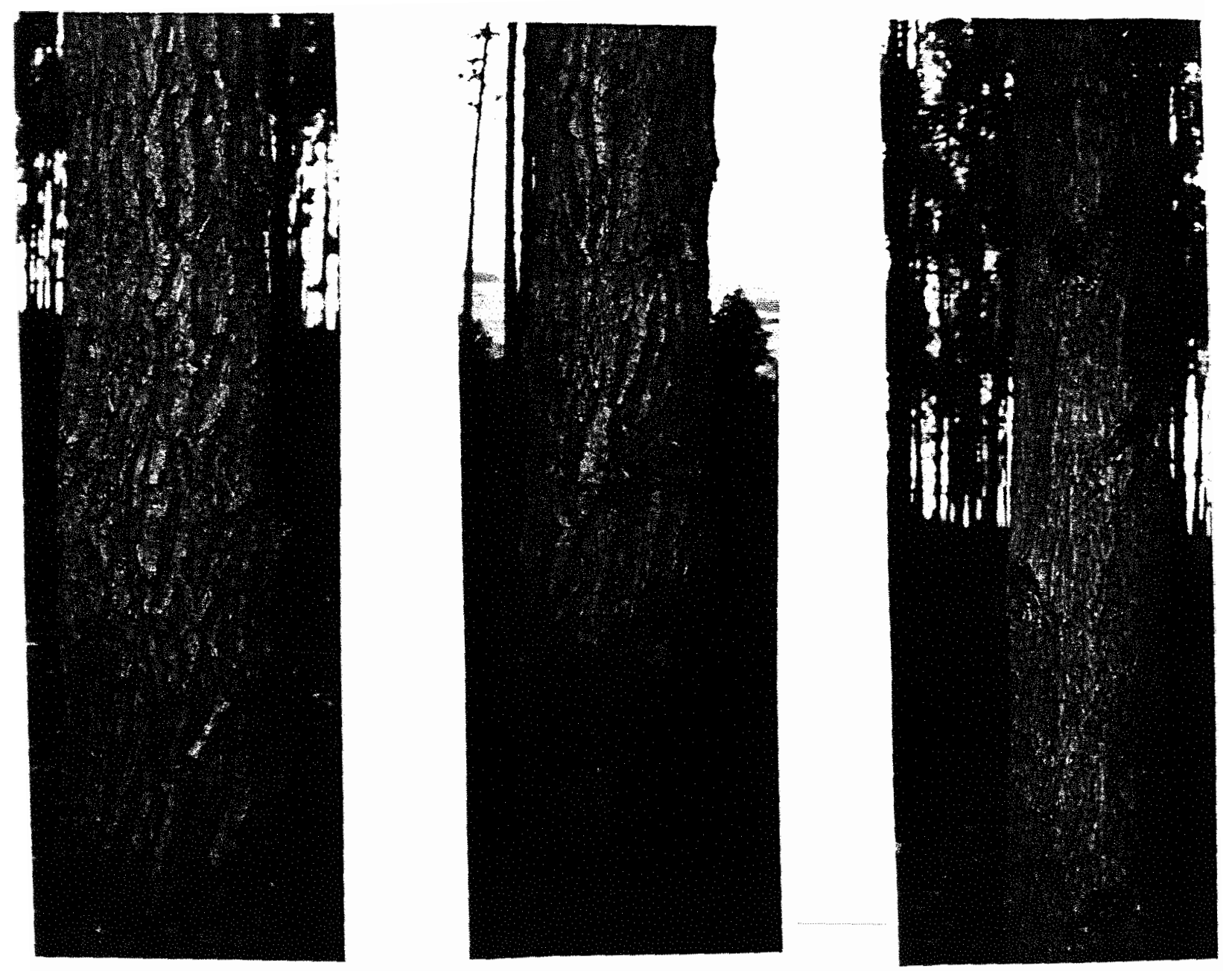

Variações do ideotipo de casca fibrosa escura. com extremo fissurado/ sulcado chegando a formar placas rijas ( à esq.), o normal ao centro e umtipo mais claro e com fibras rasas e bem firmes. 

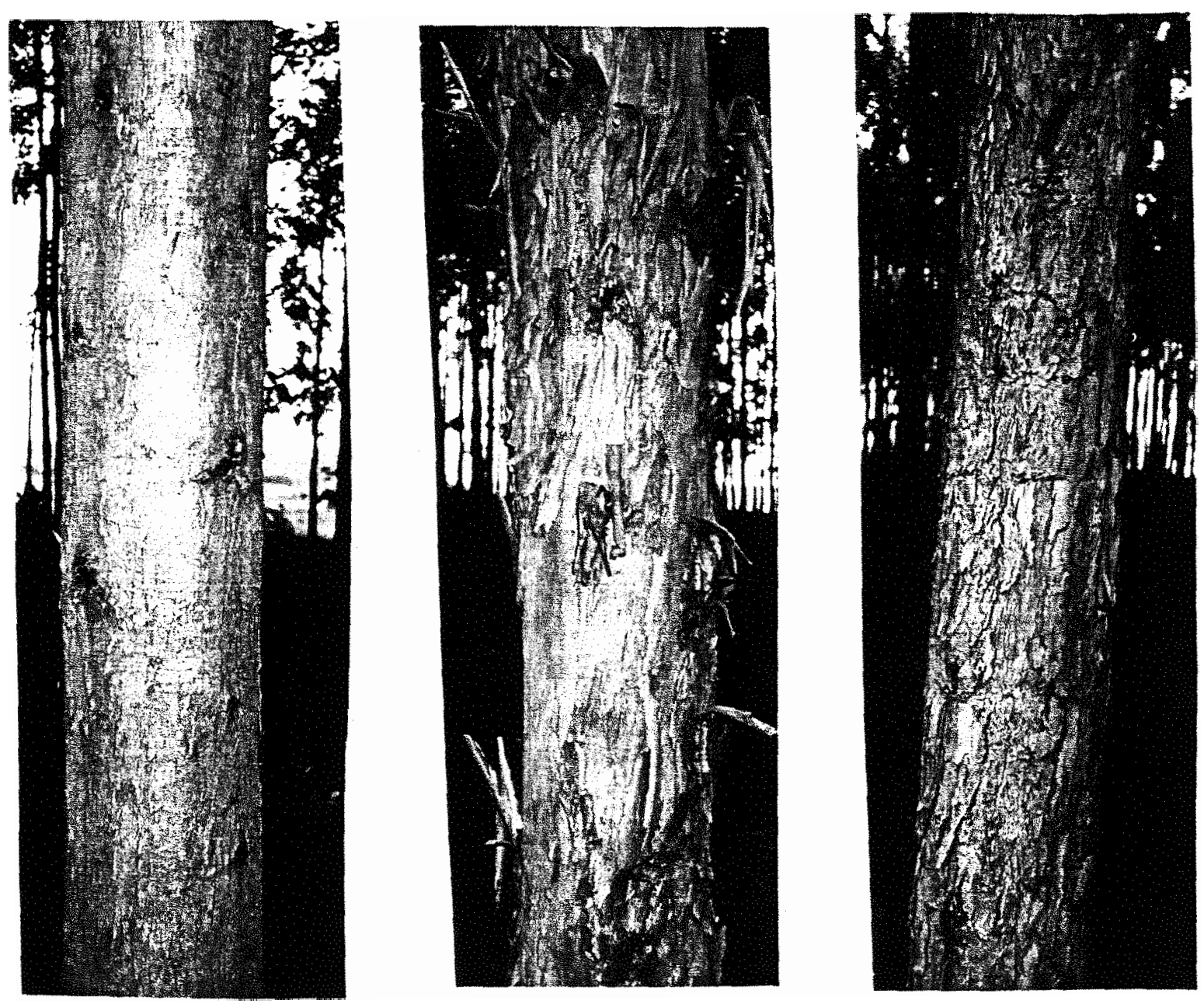

Variações do ideotipo de casca rugosa parda, com extremo descascando em lamelas espessas, chegando a formar placas soltas ( à dir.) , o normal ao centro e um tipo mais cinza e quase sem apresentar fendas, com casca fina e aderente. 

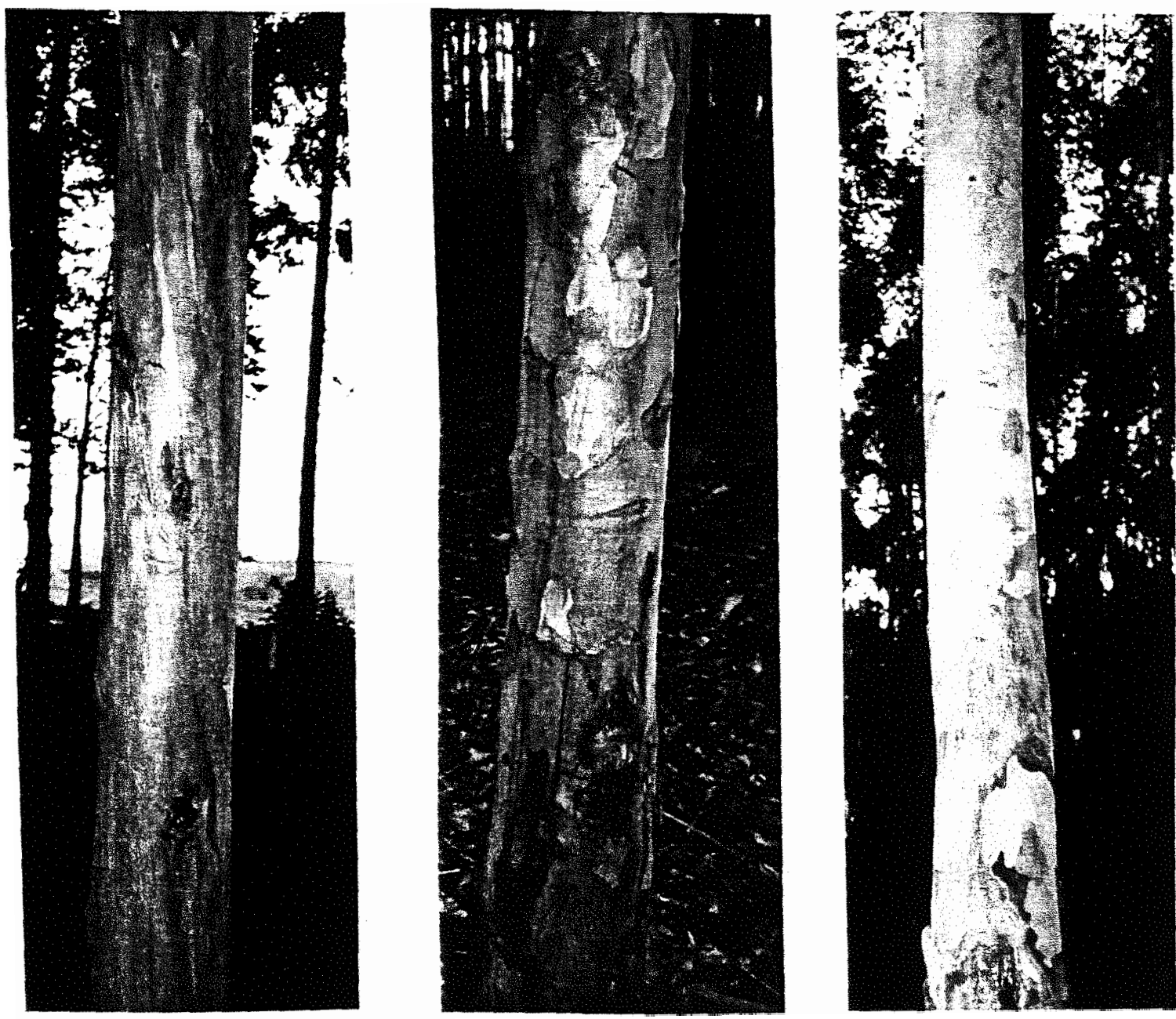

Variações do ideotipo de casca lisa clara. com extremo

muito deiscente e branco, típica "gum" . soltando pequenas placas muito finas e expondo a interior verde; à esq., tipo com casca rosada e com tendência a soltar finas tiras. 


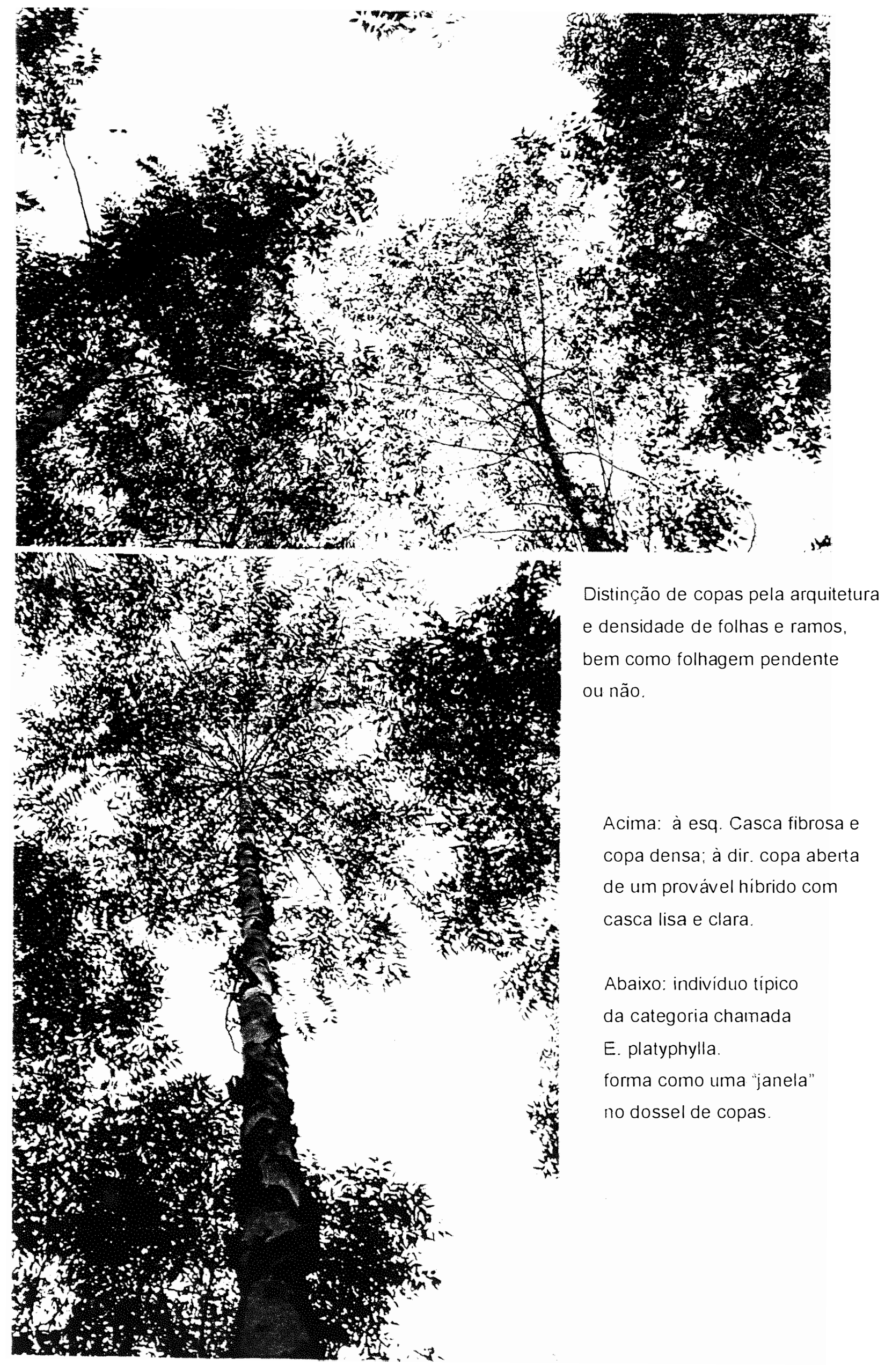



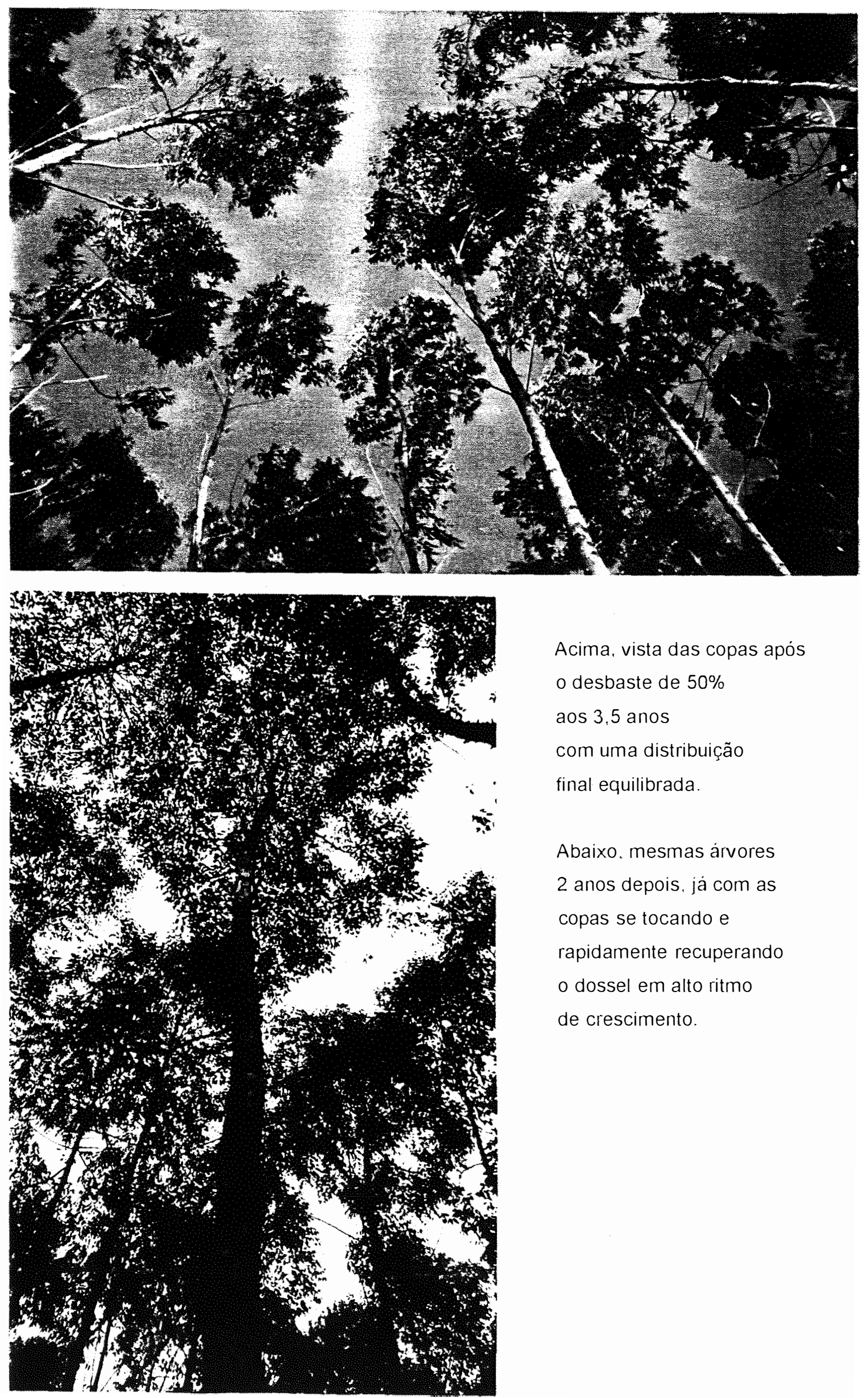

Acima, vista das copas após

o desbaste de $50 \%$

aos 3,5 anos

com uma distribuição

final equilibrada

Abaixo, mesmas árvores

2 anos depois, já com as

copas se tocando e

rapidamente recuperando

o dossel em alto ritmo

de crescimento. 
DADOS DE COLETA

FICHA NS ns

ESPECIE

ORIGEI:

COLETA

OBSERVAÇOES

DATA

ENDEREÇO .
: Nome cientifico e Rutor Eucalyptlus uraphyllá S.T. Blacher. Nome comum R.: PLPU

: País Inde-insie Estado ou Prov. HII_ Regiāo Ilenele Latitude $3240150^{\prime \prime}$ iongitude $12=2$ cersonaltitude 750 (m) Detalhes do Local Povoamanto puro E. uraphilla nas ensastas dn uri? cäo denomi:"zdo Enon

Direçāo da :nclinaçāo ___." Declividade

Tipo de Cobertura. Forestal Beni raciucifria

Tipo de solc ori dinário de emiprões vulröritras

Condiçōes de umidade do solo s.ęe

Espécies Associadas foveamsntos cnde predominam na maicr namtodas érvores. dois tipos distinics re cases

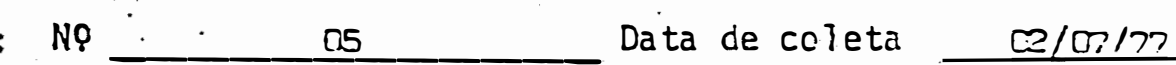
No de ārvores coletadas $14 \quad$ Idade Altura médiz $3 \overline{3}, 50 \mathrm{~m}$ Diämetro mēdio $69 \mathrm{~cm}$ Sublinhe a Palavra Aplicáve?

Coleta de (Ärvores em pé). (Ärvores Derrubadas)

Ärvores em (Plantios) (Povoamentos Naturais)

Ärvores ( Isoladas) (Povoamentos Abertos) (Povoamentos Densos) Frutificação ( Wāo Iniciu.da ) ( Iniciada ) (Completa). Metodo de Extraçāo (Seca ao ar) (Estufa QC).

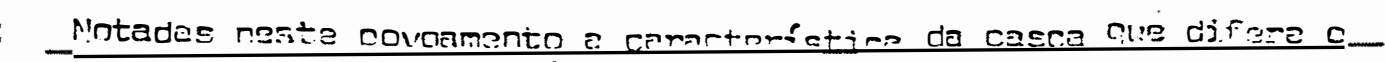
Euralyptus je flores dacusele encontrado em Tinor

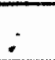

:

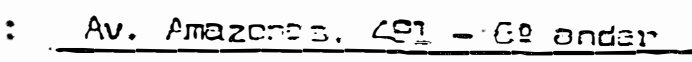

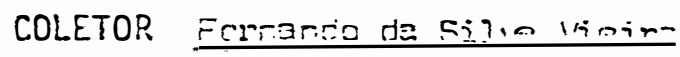
Belo Hozize. ate - 1..G. Brasil

Egon ... 
FICHA KIS $m$

ESPECIT

ORIGEl:

COLETA
: Nome cientifico e Rutor Nome comum A:: FLIPI]

: Pais Indennetis Es tacio ou Prov. $\cdots+$ Tegião Iei:atohe Latitude E033'CO" Longitude Iazane "Il" Altitude $\Delta a n$ (m) Detalhes do Local éree de coritato das espécies Fuce lunt!ia imnoin,

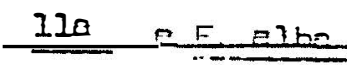
Direçāo da Inclinaçāo __s: ____ Declividade Tipo de Cobertura Florestal Semi cadusifolie

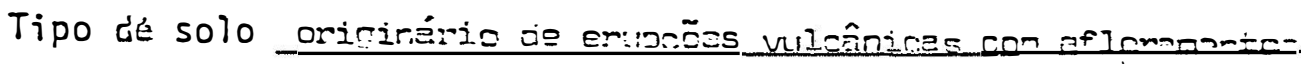
Condições de umidade do solo sern rochosos

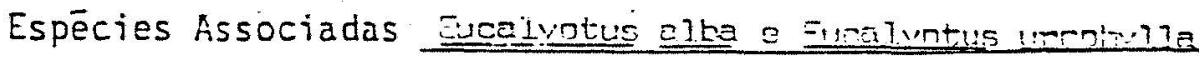

NQ m Da.ta de coleta

Nọ de ärvores coletadas $r=$

Altura média $38 \mathrm{~m}$ Diāmetro médio $n \in / m / n=$ Sublinhe a Palavra Aplicāvel.

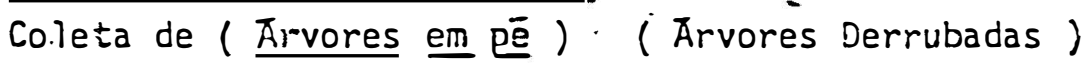
Ärvores em (Plantios) (Povozmentos Naturais) Ärvores (Isoladas) (Povoamentos Ribertos) (Povoamentos Densos) Frutificaçāo ( Não Iniciada) (Iniciada) (Completa) Metodo de Extração (Seca ao ar ) (Estufa ọc).

$\frac{-x-}{\text { Eren }}$
OBSERVAÇOES
DATA : DSTOT/77 ASSINATURA
ENDEREÇO
$:$

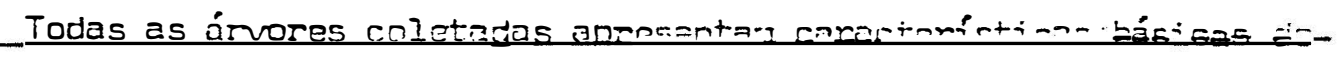 Eucalyntus uroph/lla
-
: Av. Mnezonas. 491 - Eo andian Belo Horizonte - IEE COLETOR Fornendo des Sizir li ming 

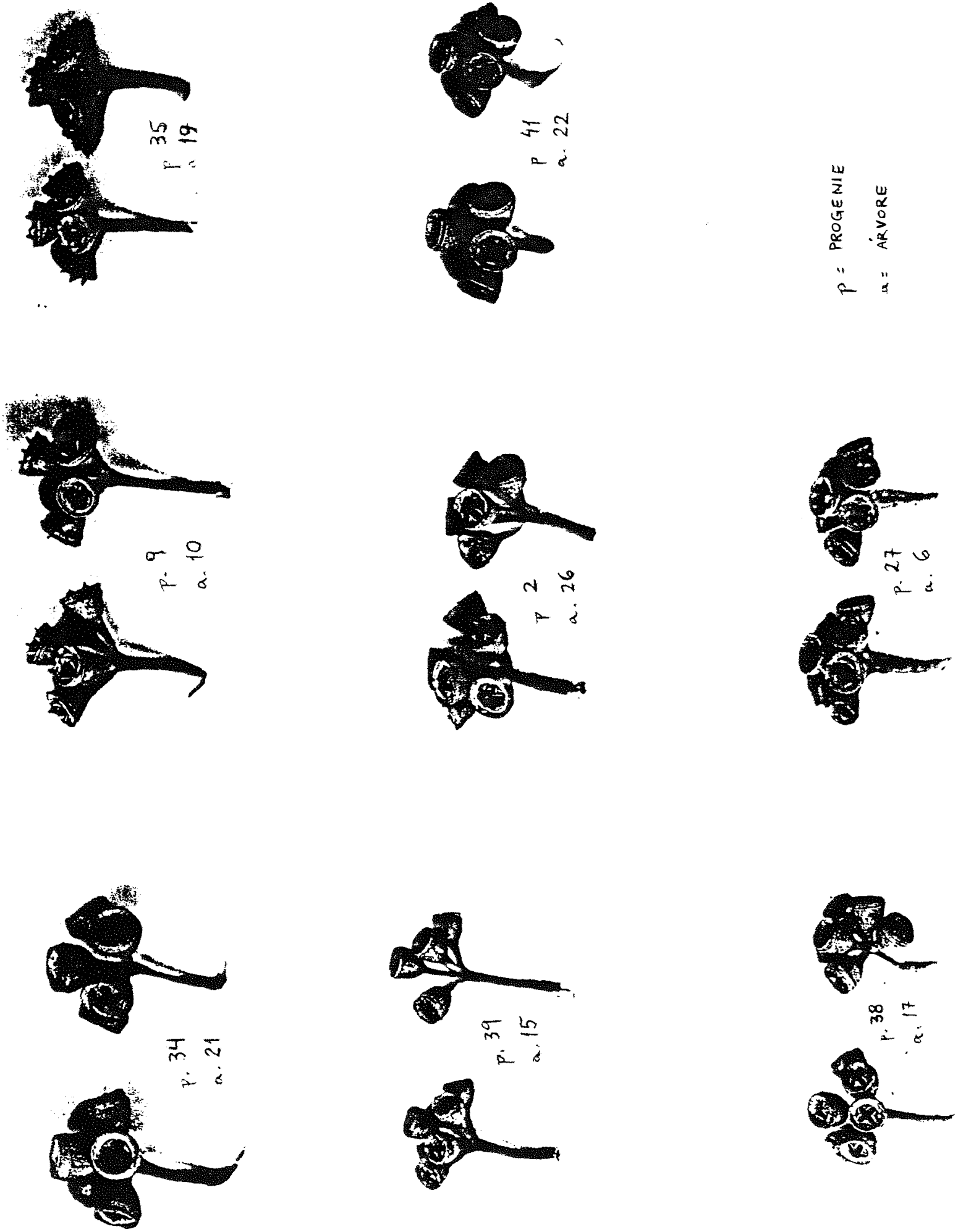

TIPOS DE FRUTOS NOS TESTES DE PROGÊNIE ESTUDADOS, apresentando extrema variação sem correlação direta com folhas ou crescimento. 
TIPOS DE FRUTOS NA POPULAÇÃO BASE QUE ORIGINOU OS TESTES (MATERIAL DA INDONÉSIA FO) Exemplos:

Eucalyptus uroptyylla var. playphylla

\section{AMOSTRAGEM}

TITULO DO PROJETO: Projeto 67 T8F Teste de procedencias/ progènies de $E$. urophytia S.T. Blake oriundas das thas de Flores.

LOCAL: Anhembi / SP

DATA DA AMOSTRAGEM: 09/90

NUMERO DA MATRIZ NO TESTE: OQ ReP II

\section{ORIGEM DO MATERIAL GENÉTICO}

MATRIZN: EG-1 PROCEDENCIA: EgON

LATITUDE: $3^{\circ} 40^{\prime}$ S/LONGITUDE: $122^{\prime} 26^{\prime}$ E / ALTITUDE (metTOS): 780

GRAU DE MELHORAMENTO Populaçăo-tase

\section{CARACTERISTICAS MORFOLOGICAS}

CASCA: $80 \%$ de casca

FRUTO: ioma do calice: forma de bartil

disco incluso

$\mathrm{n}^{3}$ de truto intrutescencia:

Eucalyptus urophylla var. platyphylle

AMOSTRAGEM

TITULO DO PROJETO: Projeto 67 T8F Teste de procedenciasI progenies de $E$. urophylla S.T. Blake oriundas das lihas de Flores.

LOCAL: Anhembi / SP

DATA DA AMOSTRAGEM: 09/90

NÚMERO DA MATRIZ NO TESTE: 01

ORIGEM DO MATERIAL GENÉTICO

MATRIZ No: H-7 PROCEDENCIA: LeWotobi

LATITUDE: 8'31' S I LONGITUDE: 122 46' E I ALTITUDE (metros): 500

GRAU DE MELHORAME'NTO: População-base

CARACTERISTICAS MORFOLÓGICAS:

CASCA: $40 \%$ de casca

FRUTO: forma do cálice: amplo/cônico

disco: incluso

$\mathrm{n}^{0}$ de fruto/ infrutescência: 7

Fonte: Scanavacca \& Ferreira, 1996. IPEF

Relatório projeto E. platyphylla na EERNR - Anhembi procedências de Flores - Indonésia ñoo public. 

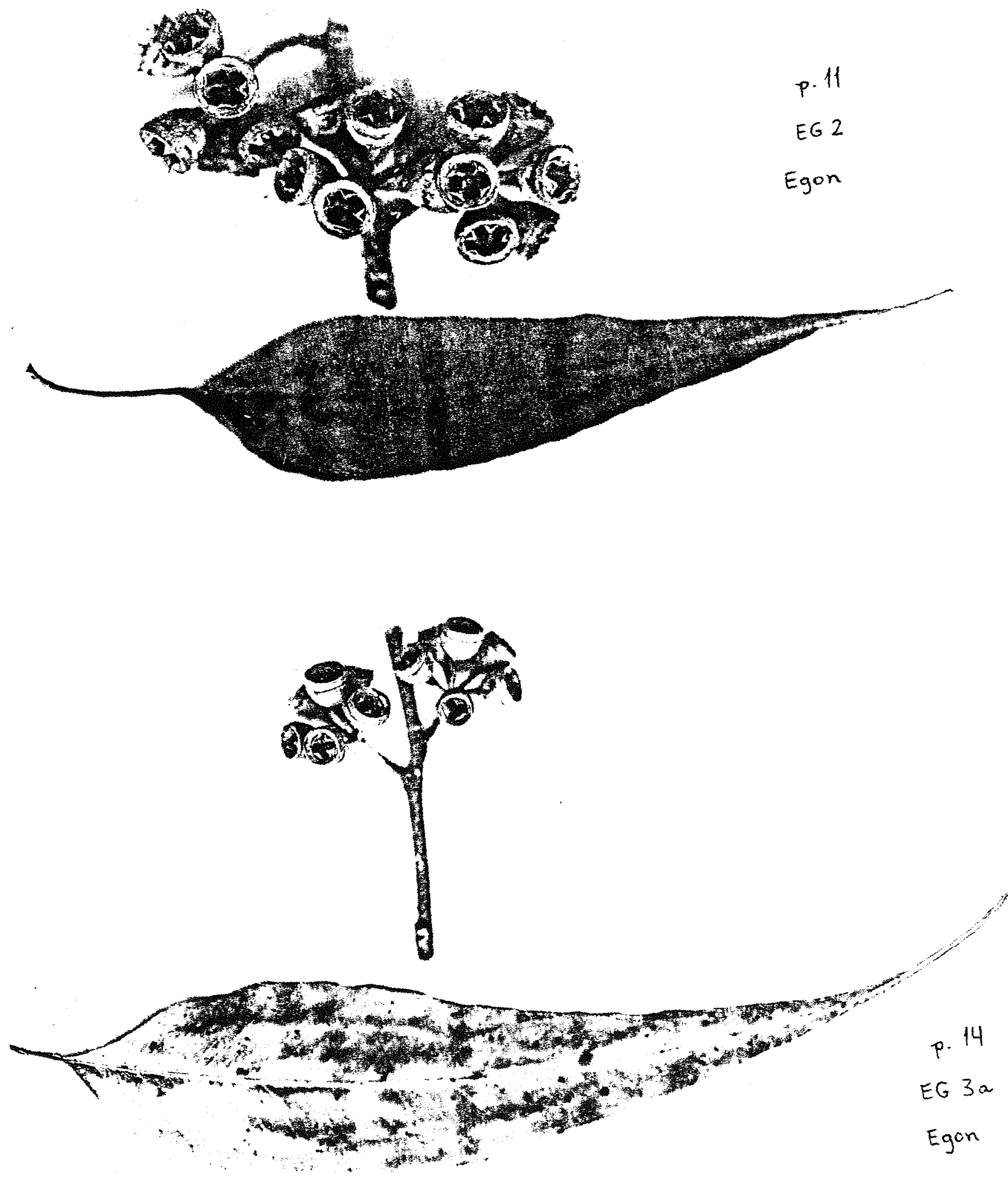

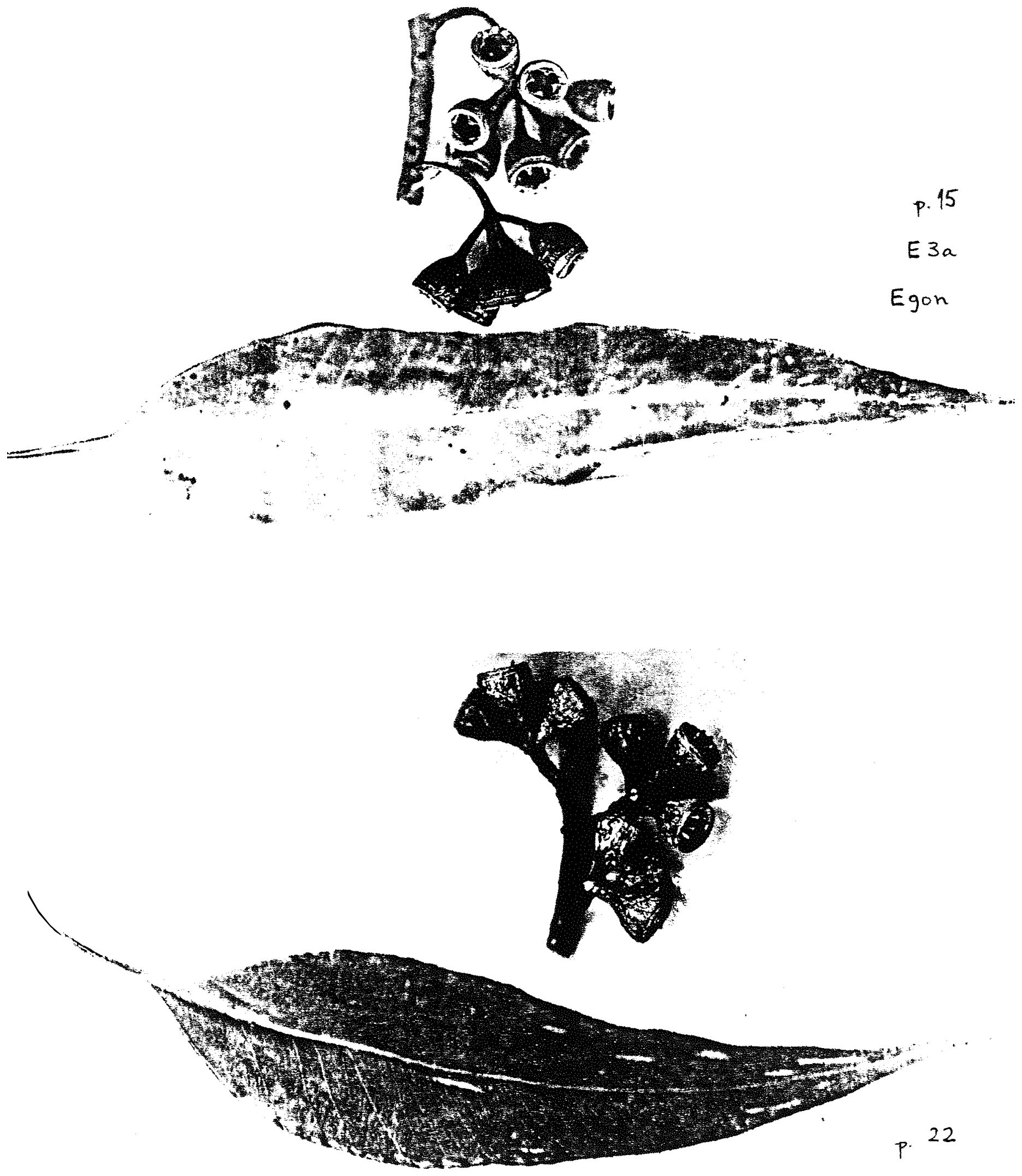

PE 12

Egon II 


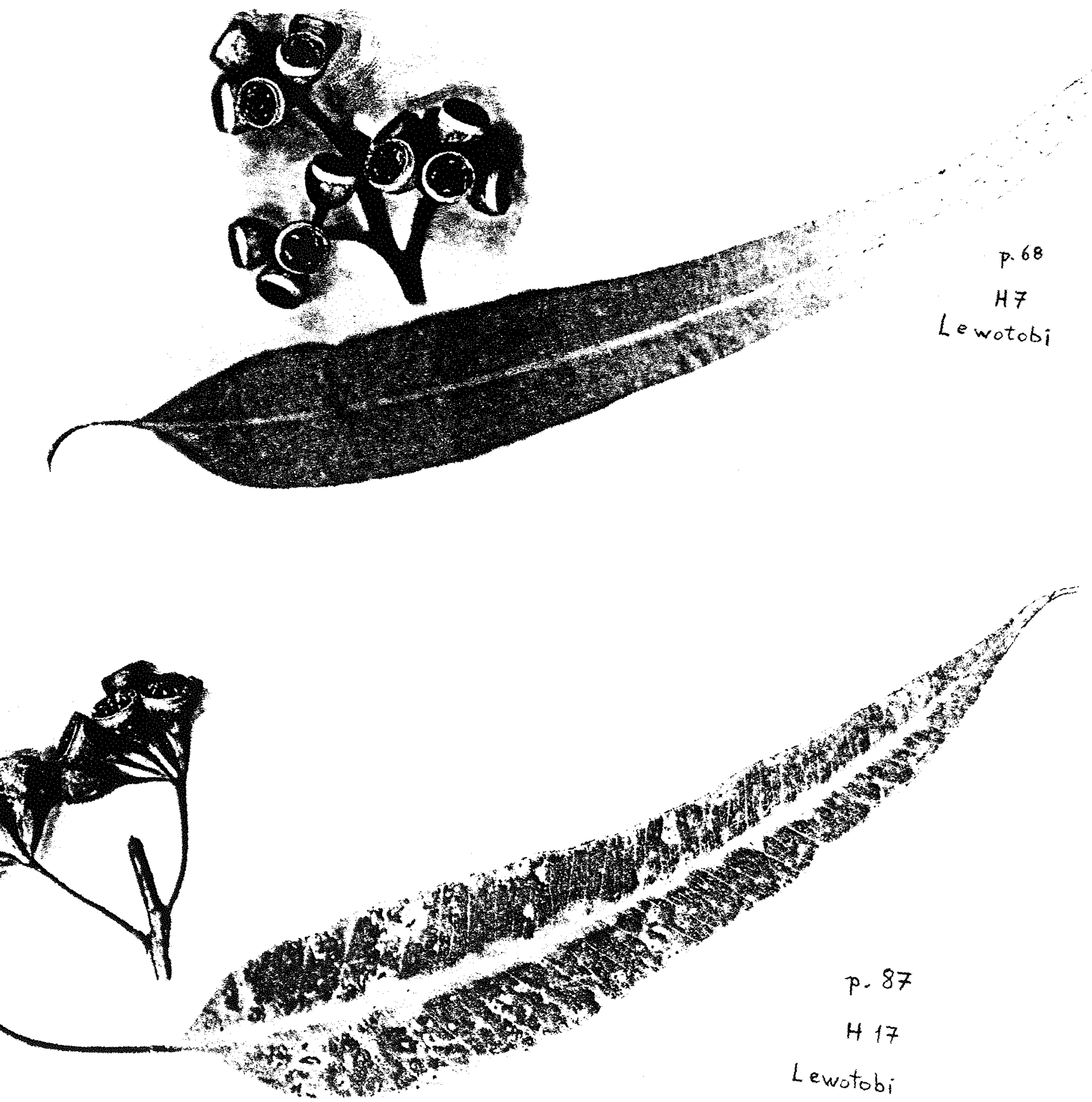



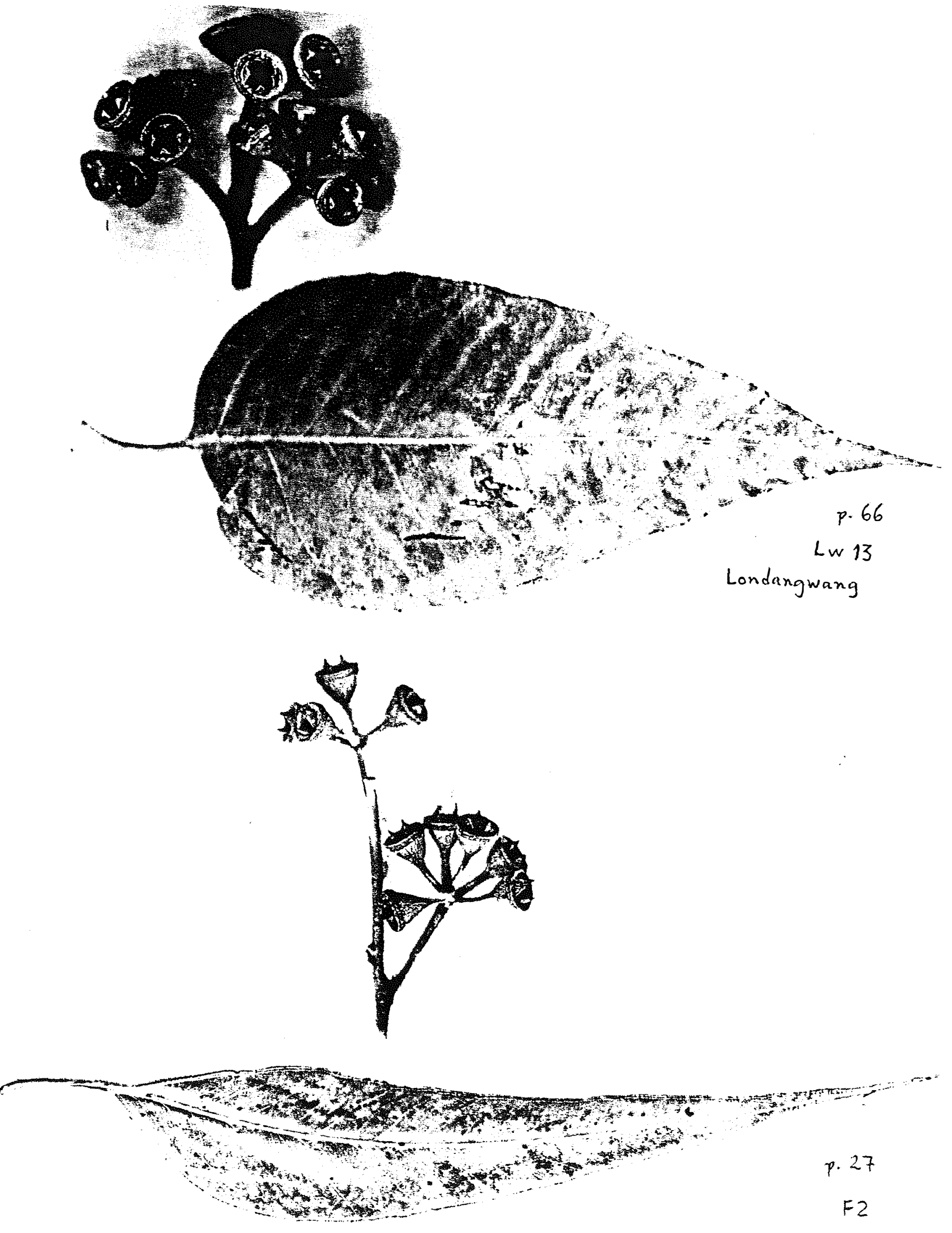


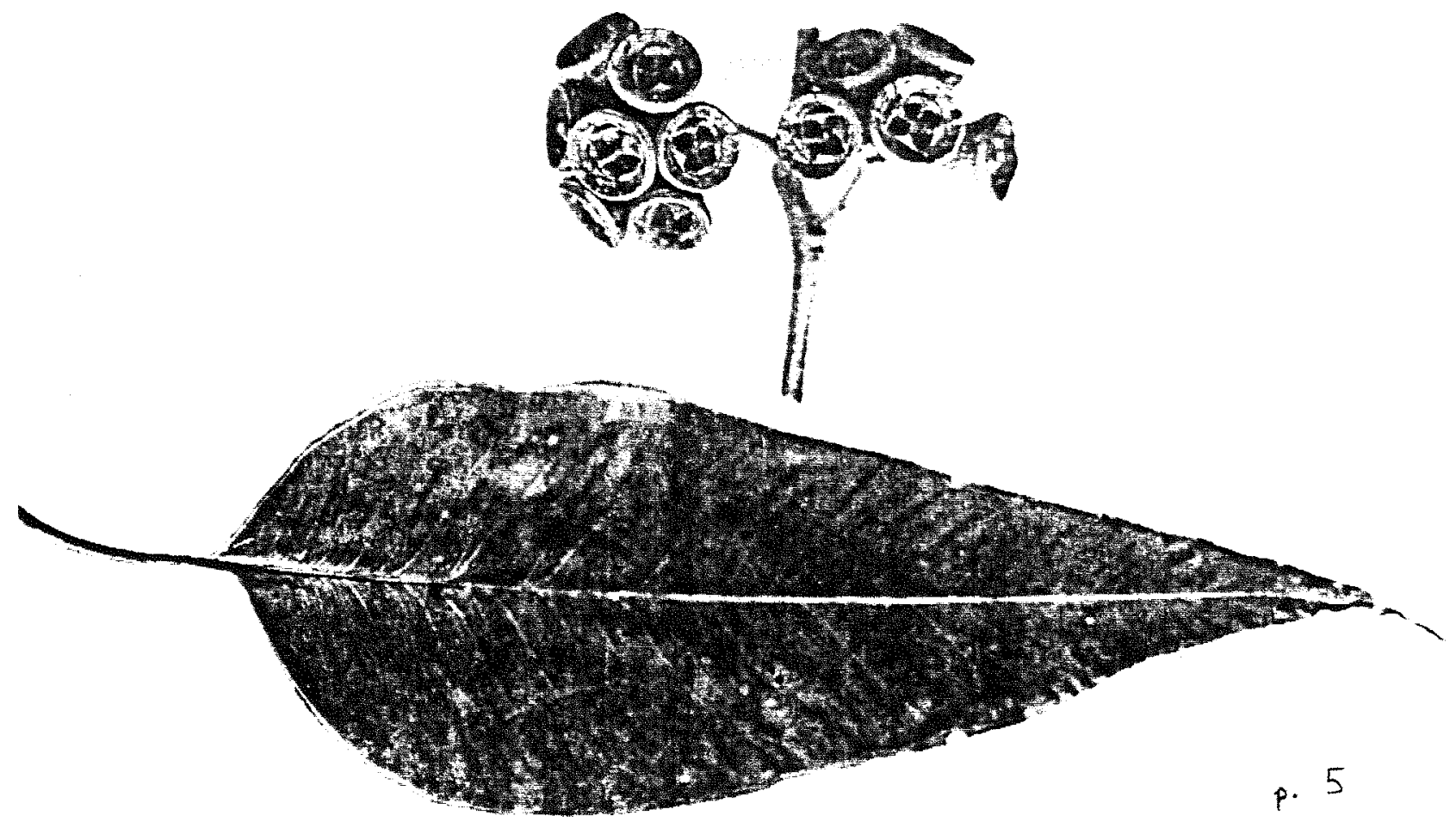

SW3

Saler Wukoh 


\section{Amateurs de volcans}

Le rédacteur des Why Files, David Tenenbaum, s'est informé au zoologiste australien lan Thomton des leçons écologiques pouvant être tirées suite à l'explosion du Krakatau. Voici sa réponse qui fut rédigée le 7 janvier 1996.

David,

1. Une leçon optimiste: que l'écosystème tropical est capable de se regénérer d'extrêmes, voire dramatiques dommages s'il est laissé à lui-même et si nous lui laissons du temps. À l'intérieur d'un siècle, le restant du Krakatau, Rakata, sur lequel on n'a pu voir d'herbe pendant un an, est maintenant couvert d'une forêt tropicale de la base à son sommet de 800 mètres. Sur les trois îles dévastées en 1883, il y a maintenant 400 espèces de plantes, des milliers d'espèces d'arthropodes incluant 54 espèces de papillons, plus de 30 sortes d'oiseaux, 18 espèces de mollusques de terre, 17 espèces de chauve-souris et 9 espèces de reptiles. Toutes ces espèces ont dû franchir 44 kilomètres d'eau salée juste pour atteindre les îles et encore plus pour s'établir.

2. Que ce ne sont pas toutes les composantes de l'écosystème qui se développent au même rythme; certaines atteignent un palier bien avant que les autres ne le fassent.

3. De la comparaison du processus d'assemblement de l'île volcanique active Anak Krakatau (la fille de Krakatau) qui a émergé de la mer en 1930 au milieu du cadeira résultant de l'éruption du Krakatau en 1883 (qui s'est stérilisé par lui-même en 1952) nous savons que le processus

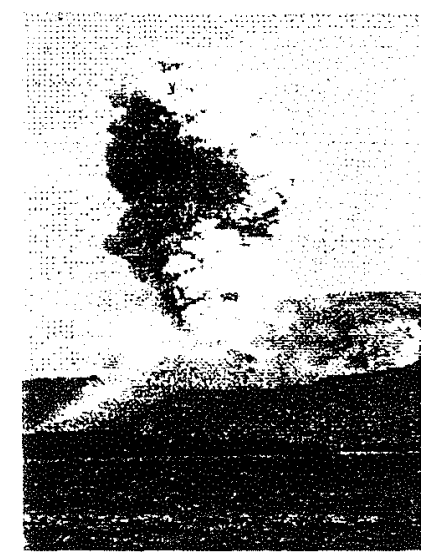

tine coulée de matières pyroclastiques descendant sur les thancs d'Anak

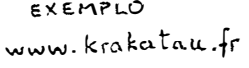

